UNIVERSIDADE DE SÃO PAULO

FACULDADE DE FILOSOFIA, LETRAS E CIÊNCIAS HUMANAS

DEPARTAMENTO DE GEOGRAFIA

PROGRAMA DE PÓS-GRADUAÇÃO EM GEOGRAFIA FÍSICA

JOSÉ CAMILO RAMOS DE SOUZA

A GEOGRAFIA NAS ESCOLAS DAS COMUNIDADES RIBEIRINHAS DE PARINTINS: ENTRE O CURRÍCULO, O COTIDIANO E OS SABERES TRADICIONAIS

Orientadora: Prof ${ }^{a}$. Dra. Regina Araujo de Almeida

SÃO PAULO

2013

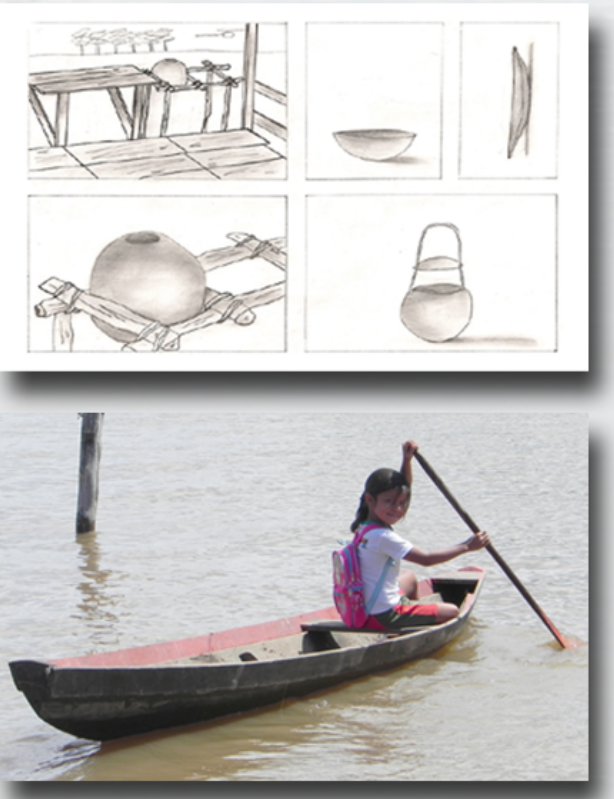

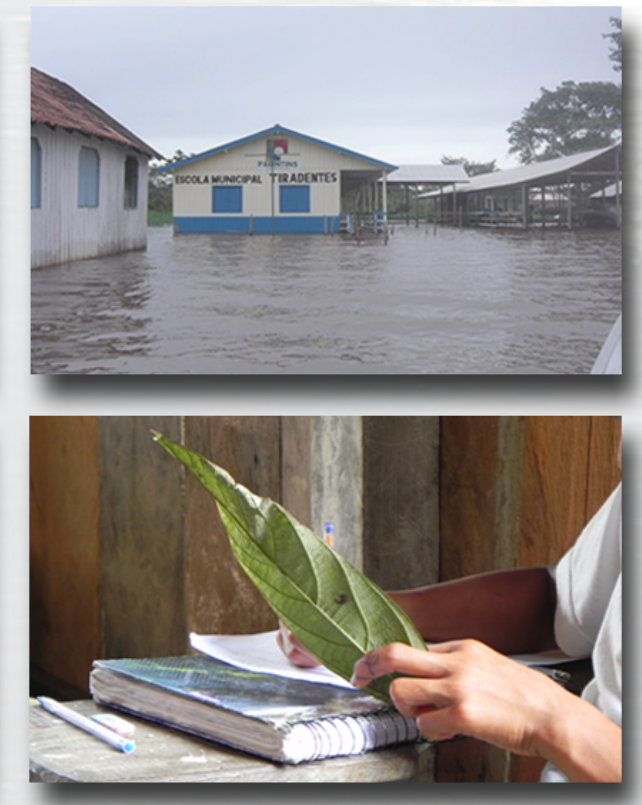

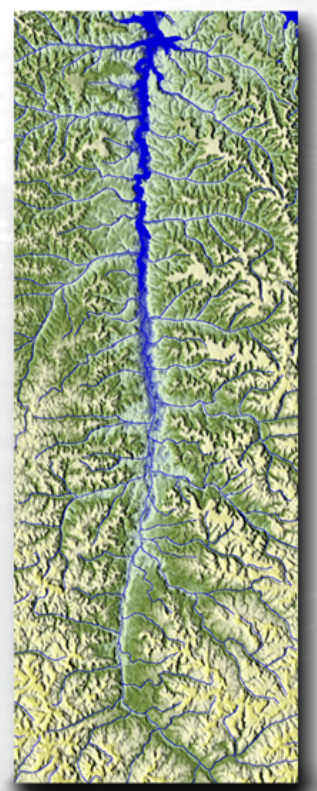

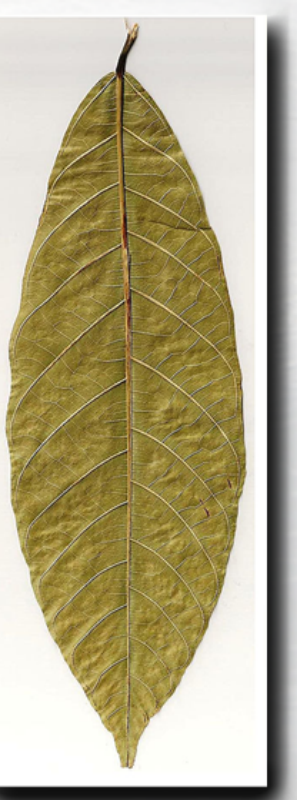


JOSÉ CAMILO RAMOS DE SOUZA

\section{A GEOGRAFIA NAS ESCOLAS DAS COMUNIDADES RIBEIRINHAS DE PARINTINS: ENTRE O CURRÍCULO, O COTIDIANO E OS SABERES TRADICIONAIS}

Tese apresentada ao Programa de PósGraduação em Geografia Física do Departamento de Geografia da Faculdade de Filosofia, Letras e Ciências Humanas da Universidade de São Paulo, para obtenção do título de Doutor em Geografia Física.

Orientadora: Prof ${ }^{a}$. Dra. Regina Araujo de Almeida 
Autorizo a reprodução e divulgação total ou parcial deste trabalho, por qualquer meio convencional ou eletrônico, para fins de estudo e pesquisa, desde que citada a fonte.

Catalogação na Publicação

Serviço de Biblioteca e Documentação

Faculdade de Filosofia, Letras e Ciências Humanas da Universidade de São Paulo 


\section{A GEOGRAFIA NAS ESCOLAS DAS COMUNIDADES RIBEIRINHAS DE PARINTINS: ENTRE O CURRÍCULO, O COTIDIANO E OS SABERES TRADICIONAIS.}

Tese apresentada ao Programa de Pós-Graduação em Geografia Física do Departamento de Geografia da Faculdade de Filosofia, Letras e Ciências Humanas da Universidade de São Paulo, para obtenção do título de Doutor em Geografia, sob a orientação da Prof ${ }^{a}$. Dra. Regina Araujo de Almeida.

São Paulo, ..de... .de 2013

Prof. (a) Dr. (a).

Prof. (a) Dr. (a).

Prof. (a) Dr. (a).

Prof. (a) Dr. (a).

Prof. (a) Dr. (a). 
Aos meus pais, José Ferreira de Souza Sobrinho e Maria Ramos de Souza, in memorian, que estão guardados dentro de mim assim como todas as lições ensinadas quando seguraram a minha mão e, ensinando-me a andar, deram-me sempre segurança na minha caminhada de aprendiz. Foram os meus grandes professores, apesar de não serem letrados na escola formal, mas eram sábios em conhecimentos tradicionais e assim me ensinaram a enfrentar de frente os obstáculos da vida. A partir de seus ensinamentos, aprendi a aprender e a ter sempre coragem para seguir em frente e construir conhecimentos e ao mesmo tempo socializá-los em um processo contínuo de aprendizagem em vias de mão dupla: aprendendo e ensinando, ensinando e aprendendo. Foram eles que me ensinaram a olhar de dentro as realidades comunitárias amazônicas na beira do rio, várzea e terra firme - onde moramos - entre uma história para dormir ou uma história de crendice amazônica para ensinar a respeitar o rio ou a mata. Eu tive a oportunidade de viver entre enchente e vazante, fartura e falta de alimento, mas sempre com o propósito de nunca desistir diante dos problemas, e, aprendi a tratar todos sem diferença, porque somos gente, somos humanos e pretendemos viver em uma sociedade mais humana e mais igualitária. Os valores sociais e morais primários a mim repassados são sempre exercitados continuamente em todos os momentos da vida. Com eles aprendi o valor da vida e também a trabalhar na juta, na roça, na coleta de frutas, de cascas e de outros produtos de ordem natural. Aprendi a pescar e a viver liberdade intensamente, com responsabilidade. Com os seus saberes adquiridos na escola da vida, foi me mostrado o mundo, ensinaram-me a ler o mundo com o olhar da crítica, posicionar-me contra toda e qualquer miséria humana dentro e fora da minha realidade vivida. 


\section{AGRADECIMENTOS}

Um trabalho de tese não se constrói solitariamente, apesar de ser quase uma escrita individual. É construído nas relações pessoais, sociais, culturais, econômicas; isto porque são momentos de renúncias, de compreensões, de diálogos, de abandonos, de desesperos, de orientações, enfim, de construção de uma obra e de construção de si mesmo em processo contínuo de aprender fazendo, observando, ouvindo, em uma entrega total. Este alicerce se fez presente nas palavras de Regina Araujo de Almeida, que na forma amigável de dialogar ou nas conversas de descontração, nos risos e gargalhadas, mostrava as leituras a serem feitas; ajudou a pensar e reestruturar o objeto pesquisado, mostrando o caminho a ser seguido para alcançar os objetivos propostos no projeto de tese. Incansável na orientação, deixou seu lar em São Paulo para conhecer o lugar da pesquisa deste orientando, no Amazonas; abriu perspectivas futuras e, no momento em que estava superlotada de trabalho, dividiu o tempo para dar atenção ao orientando. Como a energia do rio Amazonas, Regina conduz o orientando ao conhecimento e, quando este tenta desviar do caminho, segura pela mão demonstrando com isto a grandeza da educadora. Wanderley Hollanda Cavalcante, nas conversas amigáveis sempre mostrando o quanto conheceu e conhece de Amazônia e, se sentindo livre, sempre fez questionamentos sobre o objeto pesquisado e isto se traduziu em formas de pensar, num processo de desconstrução, reconstrução e construção do objeto pensado e pesquisado; forma que encontrou de auxiliar neste trabalho de tese. José de Oliveira Ramos, sem ele talvez não conseguisse chegar aonde cheguei nesta construção de tese; deixou seu trabalho, sua casa e seus afazeres na cidade para pilotar a voadeira (lancha rápida) nas idas e vindas do e para o lugar da pesquisa. Nas viagens, os diálogos demonstravam o conhecimento de quem viveu e vive as realidades ribeirinhas. Aprendi a renovar meu olhar e construir uma forma diferente de ler a realidade de várzea e terra firme. Pedro Paulo Simas Nôvo, meu cunhado que estendeu sua mão amiga ao emprestar sua voadeira e por compreender a importância da pesquisa para a construção da tese; sem esta ajuda também não seria possível chegar aonde cheguei nesta construção de conhecimentos ribeirinhos amazônicos. Meus irmãos, Joana de Souza Nôvo, Raimundo Tito Ramos de Souza, Maria Irineuza Ramos de Souza, Francisco Candindé Ramos de Souza, Maria do Perpétuo Socorro Ramos de Souza, Marconi Ramos de Souza, que sempre me deram apoio e me incentivaram a continuar os estudos, mesmo porque, a oportunidade nós construímos dentro das nossas dificuldades familiares. Raimundo Patrício Gomes Silva, meu cunhado, que oportunizou 
contato com arreios de pesca e diálogo com pescador, senhor Valdomiro Campos Ferreira. João Bosco dos Santos Brasil, coordenador do curso de Geografia, Centro de Parintins, apoiador de todas as nossas iniciativas e necessidades para a condução da pesquisa. Estevan Bartoli, Tatiana Barbosa, Carmem Lourdes, Reginaldo Luiz Fernandes, Alem Silva, João Danúzio, Charlene Muniz, professores do curso de Geografia, sempre atenciosos às nossas solicitações e apoiando nesta luta de doutoramento. Em especial a Tatiana Barbosa, que assumiu a disciplina no segundo semestre de 2012 para que eu pudesse ser liberado - meu respeito e amizade. Lucélida de Fátima Maia da Costa, amiga que sempre leu meus textos e, sendo da matemática, dizia o que não entendia da Geografia, mostrando as falhas do que estava sendo construído na tese. Jucélia Oliveira Vidal, amiga e agrônoma, que sempre deu esclarecimentos sobre atividades agrícolas dos ribeirinhos e também presenteou com livros sobre a Amazônia, solos da Amazônia e agricultura familiar. David Xavier, diretor do Centro de Estudos Superiores de Parintins, incentivador e que deu todo apoio necessário em todos os momentos de estudo, pesquisa e viagem a São Paulo. José Aldemir de Oliveira, reitor da Universidade do Estado do Amazonas. Fundação de Amparo a Pesquisa do Estado do Amazonas - FAPEAM, concedente de bolsa para cumprimento de estágio na Universidade de São Paulo - USP. Waldirene do Carmo (Wal), sempre com sorriso aberto, atendeu minhas solicitações no Laboratório de Ensino e Material Didático da Geografia - USP. Marcelo Machado Silva, na sua forma de ser e falar, ensinou-me a pensar mais tecnicamente a geografia e a cartografia, e também dedicou parte de seu tempo em construir mapas e formatar esta tese. Willer Hermeto Almeida Pinto, que dividiu seu tempo de estudo de tese para construir mapas e cartas-imagem quando solicitado por mim. Dr. Manuel Fernandes e Dr.Alfredo Queiroz, na avaliação de qualificação, deram sugestões importantíssimas de leitura e fizeram questionamentos; foram precisos no olhar de dentro da realidade ribeirinha amazônica. Vânia Maria de Matos Santos - gestora da Escola Tiradentes, que dedicou apoio e atenção a todo processo de pesquisa. As Professoras Nelcélia Oliveira da Silva, Rosa Ribeiro, Sônia Quêne Silva de Oliveira, Gerlane Batista e todos os funcionários da escola, compreendedores e apoiadores de todo trabalho de pesquisa. Jane Maria dos Santos de Souza - gestora da Escola Tukasa Uetsuka, disponibilizou espaço para a realização da pesquisa e, juntamente com o apoio dos professores Admilson e Antônio, para a concretização da pesquisa. Vânia Maria da Silva Araújo, possuidora de habilidades e dons artísticos, abriu espaço em sua agenda para fazer correção de língua portuguesa desta tese. Para fechar este momento importante, volto minha especial atenção aos que sempre estiveram ao meu lado em 
todos os momentos de ausência, distância, saudades e compreensões desta fase da vida de estudo. Momento em que a força do companheirismo, da solidariedade, da cumplicidade, sustentou o meu empenho na construção deste trabalho de tese. Sem este apoio talvez não tivesse chegado aonde cheguei: Clêise Maria Jesus Souza - esposa, companheira, cúmplice, amiga e, juntamente com André Jesus Souza, Claire Maira Jesus Souza, Lury Jesus Souza filhos compreensivos e apoiadores deste longo momento de estruturação profissional - foram e são meus esteios e meus alicerces. Foram e são minhas energias, pensando nas contribuições que posso dar em suas vidas, dediquei todo meu empenho e meu esforço neste trabalho de doutoramento. Todos aqui citados têm meu ETERNO AGRADECIMENTO, porque foram e são fortes como a brisa que suavemente movimenta a floresta. Produzem e distribuem energia como os raios no sol, no amanhecer, durante o dia e no entardecer prolongando-se a noite. Alegres e felizes como a orquestra sinfônica dos pássaros e animais da floresta amazônica, tanto a diurna quanto a noturna. Sem este apoio, sem as compreensões eu não conseguiria construir este documento de tese e nem me construir no processo da pesquisa, da escrita e da transformação dos conhecimentos empíricos em científicos. Assim nos agigantamos como as ondas dos rios que retiram pedaços das várzeas e depositam em outros lugares dentro do rio Amazonas. Aprendemos com a vivência dos ribeirinhos e socializamos estes conhecimentos aprendidos e construídos nas Escolas, nas Universidades e com todos, direta e indiretamente, porque vivemos em uma sociedade altamente dinâmica. 


\section{EPÍGRAFE}

A atividade da aula realiza o professor, como se não fosse apenas o professor que fizesse a aula, mas fosse feito por ela. Pensada nesse sentido a aula é processo e não produto, não é uma coisa com finalidade plenamente determinada, ainda que tenha um fim, não é uma coisa que possa se assemelhar à mercadoria que se troca por algo.

Manoel Fernandes 


\section{RESUMO}

O estudo da Geografia nas escolas das comunidades ribeirinhas amazônicas permite leitura da complexidade do ambiente de várzea, terra firme e das relações socioeducativas, socioculturais e socioambientais, no sentido de perceber o mundo vivido por cada sujeito aprendente a partir da relação currículo-cotidiano-saberes tradicionais ou historicamente construídos, com a finalidade de exponenciar o mundo local, regional, nacional e global para que todos possam compreendê-lo e se posicionar como cidadãos e leitores críticos da realidade sistêmica que os envolve. Esta tese procura, através de seu objetivo geral, compreender a articulação entre o currículo, o cotidiano e os saberes tradicionais preexistentes na história de vida dos estudantes que frequentam as escolas ribeirinhas do município de Parintins, evidenciando os tipos de efeitos que geram nos seus matizes e nas suas representações sociais, culturais e históricas do lugar. Para adentrar no universo ribeirinho do município de Parintins foi necessário ter um olhar multirreferencial, alicerçado na fenomenologia; a navegação pelos trajetos da pesquisa permitiu desvendar parte das comunidades ribeirinhas de Parintins, quando se procura conhecer cada lugar para perceber a geografia existente e assim poder justificar, objetivar, problematizar e estabelecer hipótese, dentro de uma indefinição definida do lugar e do objeto da pesquisa. Neste percurso vivido, despontou as construções de saberes e o lugar de vida nas relações culturais, quando os saberes do passado vivenciados nos ensinamentos do presente fazem a Amazônia se destacar como um lugar de múltiplas construções de vida amazônica a partir da vida do ribeirinho, na qual construiu o seu lugar de vida, seja na terra firme e várzea. Ao ancorar na escola da água, da terra e floresta em Parintins, visualizou-se a Escola, currículo e ensino de Geografia na Comunidade de Menino Deus - Itaboraí do Meio (várzea) e Santa Maria - Vila Amazônia (terra firme), onde o ensino está ligado diretamente a uma proposta curricular de visão urbana, na qual não se permite uma leitura da geografia existente em cada comunidade ou lugar de vida, onde o ensino seriado ou multisseriado tornam "águas turvas" no conhecimento, conduzindo a uma aprendizagem conturbada e sem perspectiva de novas propostas para a escola de várzea ou de terra firme de Parintins. Nesta perspectiva aprofundou-se o olhar para perceber a geografia e cartografia nas escolas das comunidades ribeirinhas de Parintins a partir de cada resposta ou desenho realizado pelos estudantes em confronto com a geografia existente nos livros didáticos, utilizado como fim e não como meio, mas como recurso didático que emerge de quem o utiliza. Então, entre o risco e o rabisco do estudante, passa-se a ter uma visão da realidade de cada aprendente, considerando que o saber tradicional nas comunidades ribeirinhas de Parintins são possibilidades didáticas para ensinar e aprender Geografia. Percebe-se a necessidade de discussões coletivas para se tentar construir um currículo multicultural que oportunize o fortalecimento do sentimento de pertencimento do estudante da escola de várzea e terra firme a partir da importância do lugar vivido como lugar de vida.

Palavras chave: Amazônia. Ensino. Geografia. Currículo. Saber Tradicional. 


\begin{abstract}
The study of Geography in schools of Amazonian riverside communities allows us to read the complexity of the floodplain and upland environments and the socio-educational, sociocultural and social-environmental relations, leading to the perception of the world lived by each individual learner, from the relation between curriculum-daily life-traditional or historically constructed knowledge, with the purpose of highlighting the local, regional, national and global world, so that everyone can understand it and position themselves as citizens and critical readers of the systemic reality that surrounds them. This thesis seeks, through its general objective, to understand the articulation between the curriculum, daily life and traditional knowledge existing in the life stories of students who attend riverside schools in the city of Parintins, showing the kinds of effects that are generated in nuances and in the social, cultural and historical representations of the place. To enter the riverside universe of the city of Parintins, it was necessary to have a multi referential look, grounded in phenomenology; by navigating the routes of the research, part of the riverside communities of Parintins were unraveled, while we tried to get to know each of the places to identify the existing geography and then be able to justify, objectify, discuss and establish a hypothesis, within a definite vagueness of the place and object of research. In this experienced course, constructions of knowledge were revealed as well as the place of living in cultural relations, when knowledge from the past, experienced in the teachings of today, make the Amazon stand out as a place of multiple constructions of Amazonian life, starting from the riverside life, where they built their place of living, whether in upland or floodplain. When anchoring in the school of water, land and forest in Parintins, we could visualize the school, curriculum and teaching of geography in Menino Deus community-Itaboraí do Meio (floodplain) and Santa Maria -Vila Amazônia (upland), where teaching is directly linked to a curriculum proposal based on a perspective from the city, which does not allow us to explore the geography in each community or place of living, where single-grade or multi-grade teaching become turbid waters, leading to troubled learning with no prospect of new proposals for floodplain or upland schools in Parintins. In this perspective, a closer look was given in order to perceive the Geography and Cartography in schools in the riverside communities of Parintins based on each answer or drawing done by students, in comparison to the existing Geography content in textbooks, used as an end and not as a means, but being the only teaching tool, to emerge of those using it. So, among students' cartographic scratches, we could view the reality of each learner, considering that the traditional knowledge in riverside communities of Parintins is a didactic possibility for teaching and learning Geography. It is observed the need for collective discussions to try to build a multicultural curriculum that encourages the strengthening of the feeling of belonging by students from floodplain and upland schools, based on the importance of the inhabited place as a place of living.
\end{abstract}

Keywords: Amazon. Teaching. Geography. Curriculum. Traditional knowledge. 


\section{LISTA DE MAPAS}

Mapa 1 - Localização do município e da cidade de Parintins ......................................................... 27

Mapa 2 - Localização das comunidades - lugares da pesquisa ............................................... 28

Mapa 3 - Localização dos municípios visitados para seleção da área da pesquisa ........................ 36

Mapa 4 - Localização dos municípios de Parintins e Maués ......................................................... 38

Mapa 5 - Localização das comunidades dos estudantes da Escola Tukasa Uetsuka .................... 122

\section{LISTA DAS TABELAS}

Tabela 1 - Horário de aula do Professor Admilson/2012 …...................................................... 120

Tabela 2 - Horário de aula do Professor Antônio/2012 …........................................................... 120

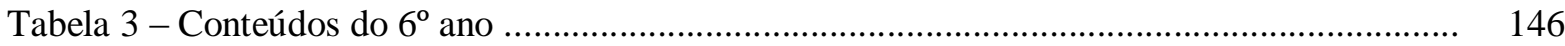

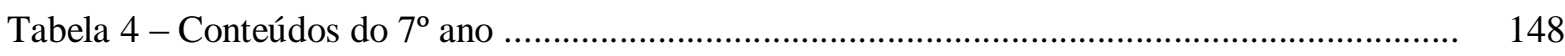

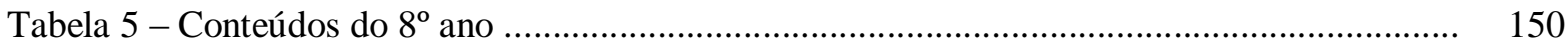

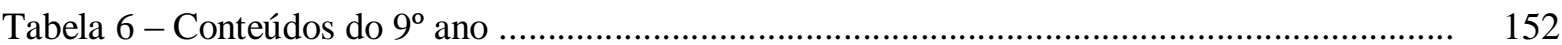

\section{LISTA DE FIGURAS}

Figura 1 - Depósito de sal. Fica sobre o fogão de lenha …............................................................. 56

Figura 2 - Panela sobre fogão de lenha .................................................................................. 56

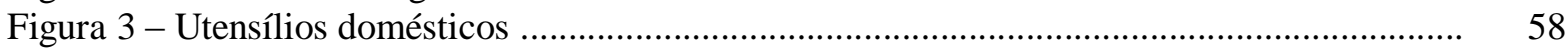

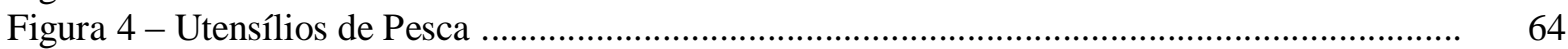

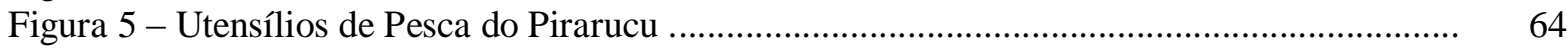

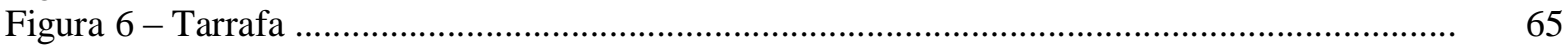

Figura 7 - Pescador armando a zagaia - tridente ………........................................................... 65

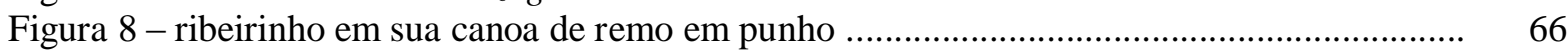

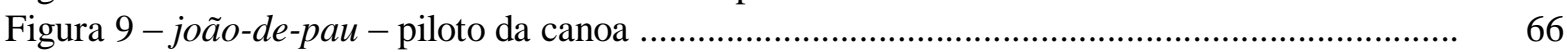

Figura 10 - Canoa - quilha - funcionando como piloto direcionador ........................................ 66

Figura 11 - Cenário de Composição Étnica da Amazônia .............................................................. 72

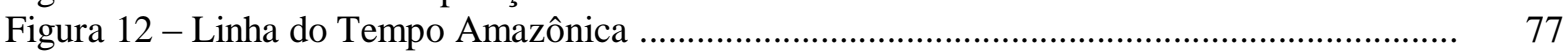

Figura 13 - Várzea - Em frente à comunidade Menino Deus- Itaboraí ........................................ 85

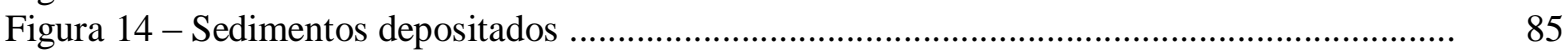

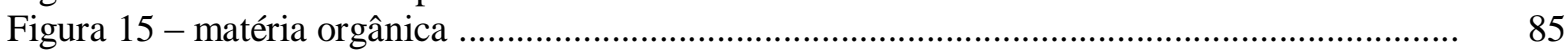

Figura 16 - Esquema para pensar o ensino de Geografia ........................................................... 92

Figura 17 - Escola Tiradentes - cheia de 2009 ............................................................................... 109

Figura 18 - Escola Tiradentes - sala de aula - cheia de 2009 ................................................ 110

Figura 19 - Prédio principal do Instituto Amazônia ...................................................................... 113

Figura 20 - Hospital do Instituto Amazônia ............................................................................. 114

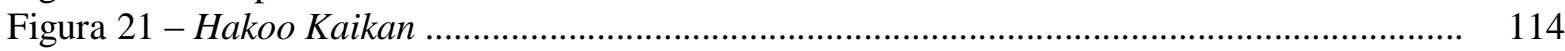

Figura 22 - Casa de J.G. Araújo em Vila Amazônia - construída em 1950/1951 _....................... 116

Figura 23 - crianças tomando banho, com a gestora da escola, antes do almoço e da aula .......... 129

Figura 24 - Balcão suspenso por causa da enchente - horta da Escola Tiradentes ...................... 130

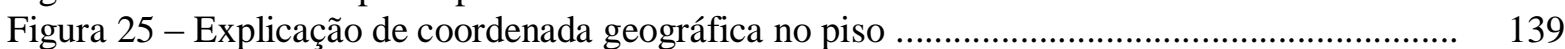

Figura 26 - Esquema representativo da tensão: escola - currículo/saber tradicional .................... 142

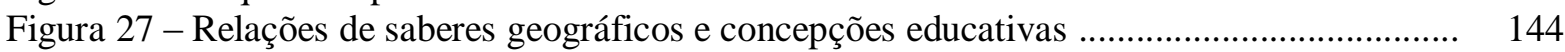

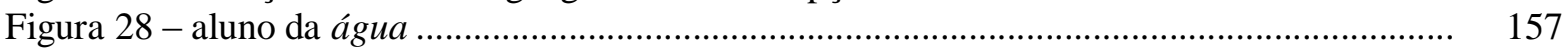

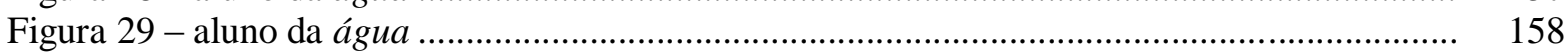

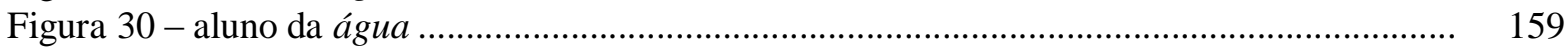

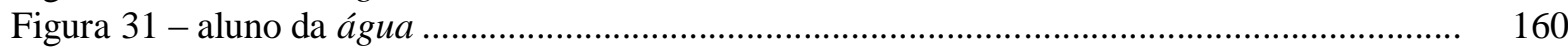


Figura 32 - aluno da terra e floresta .................................................................................... 161

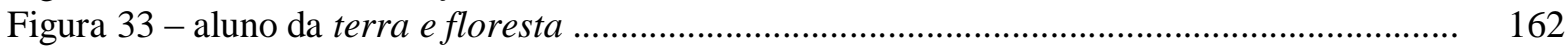

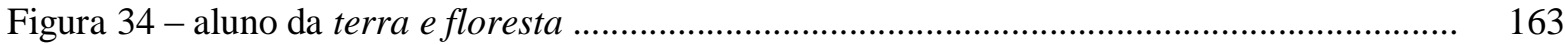

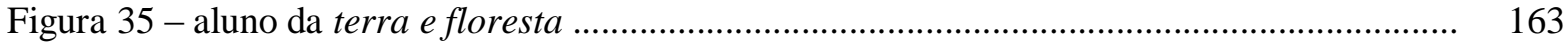

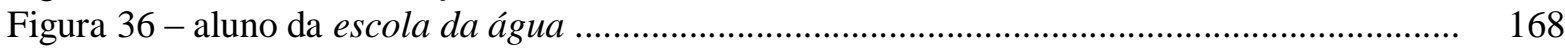

Figura 37 - aluno da escola da água ....................................................................................... 169

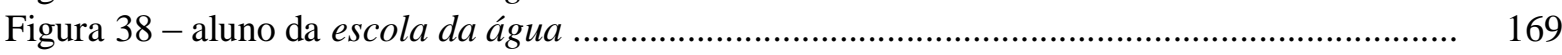

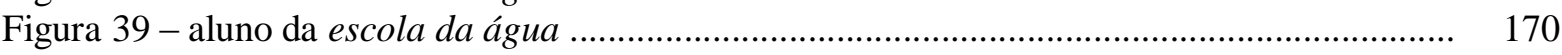

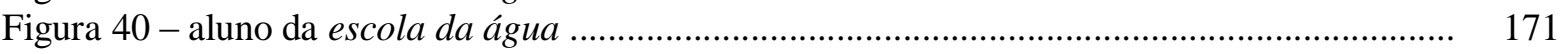

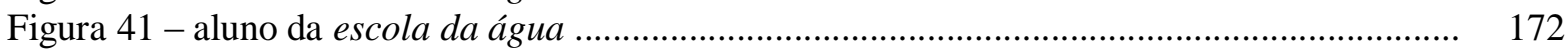

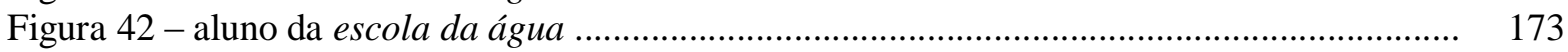

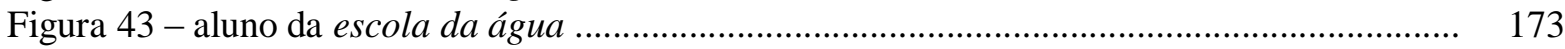

Figura 44 - escola da terra e floresta - Tukasa Uetsuka ............................................................ 174

Figura 45 - escola da terra e floresta - Tukasa Uetsuka .............................................................. 175

Figura 46 - escola da terra e floresta - Tukasa Uetsuka ........................................................... 176

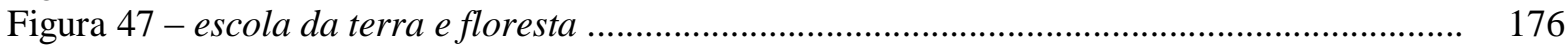

Figura 48 - aluno da água - Tiradentes ............................................................................... 177

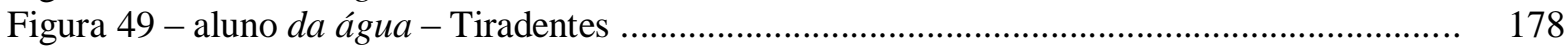

Figura 50 - aluno da água - Tiradentes ................................................................................ 179

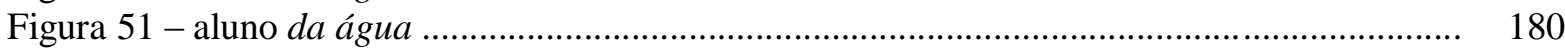

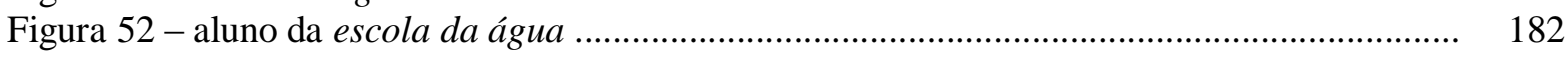

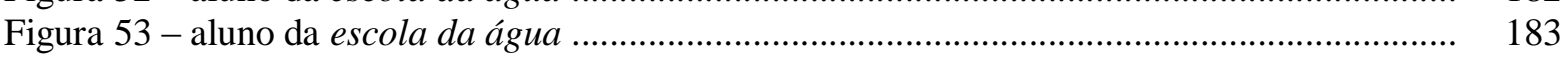

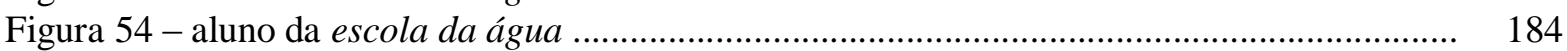

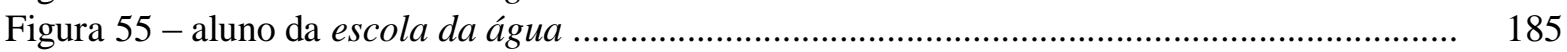

Figura 56 - escola da terra e floresta ................................................................................... 186

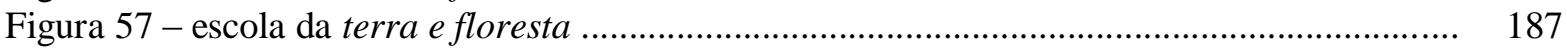

Figura 58 - escola da terra e floresta ............................................................................ 188

Figura 59 - escola da terra e floresta .................................................................................... 188

Figura 60 - mulheres do Itaboraí comercializando produtos agrícolas e peixe ........................... 195

Figura 61 - moradores do Itaboraí do meio comercializando sua produção na enchente .............. 197

Figura 62 - Ribeirinhos no período da enchente ...................................................................... 198

Figura 63 - Navio cargueiro - produz ondas que prejudicam o assoalho da casa do ribeirinho .. 198

Figura 64 - representações geográficas na folha de vegetal ............................................... 201

Figura 65 - Função da folha - Olhar Biogeográfico ............................................................... 202

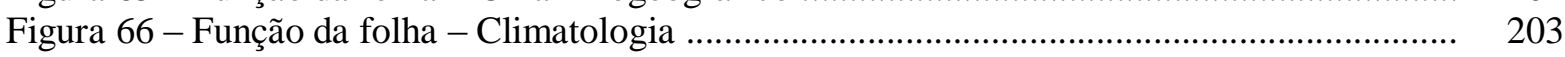

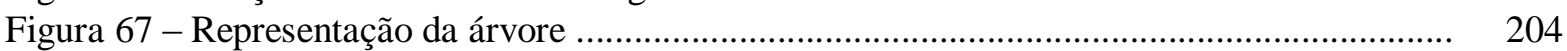

Figura 68 - Função da folha - Bacia Hidrográfica ............................................................... 205

Figura 69 - Função da folha - Meios de Transporte ................................................................... 206

Figura 70 - Função da folha - Padrões de Drenagem .......................................................... 207

Figura 71 - Função da folha - Padrão das casas ..................................................................... 208

Figura 72 - aluno em atividade com a folha vegetal .......................................................... 209

Figura 73 - Função da castanha de macaco - Estrutura interna da Terra ..................................... 210

Figura 74 - Função da castanha de macaco - Deriva continental ................................................ 210

Figura 75 - Barbante e coordenadas geográficas ..................................................................... 211 


\section{SUMÁRIO}

APRESENTAÇÃO

CAPÍTULO 1 - NAVEGANDO NOS TRAJETOS DA PESQUISA ................ $\quad 20$

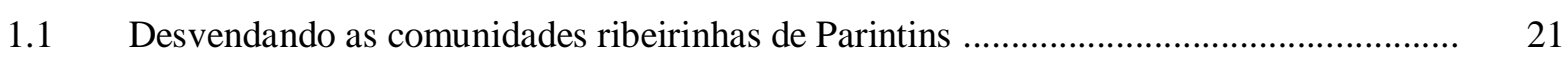

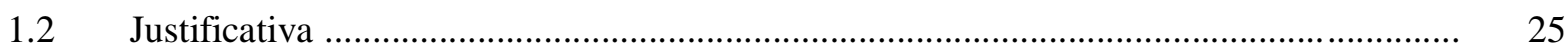

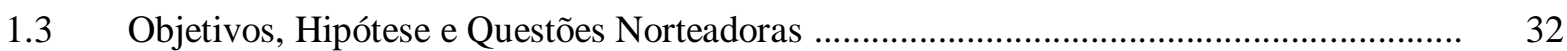

1.4 Lugares da pesquisa: uma indefinição definida ..................................................... 35

Procedimentos metodológicos .........................................................................

CAPÍTULO 2 - CONSTRUÇÕES DE SABERES E O LUGAR DE VIDA ... 50

2.1 Saberes do passado vivenciados nos ensinamentos do presente ................................ 51

2.2 Construções de vida na Amazônia: o ribeirinho ......................................................... 59

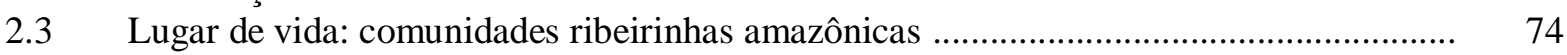

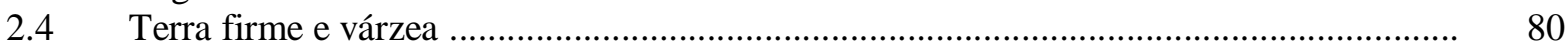

\section{CAPÍTULO 3 - ESCOLA DA ÁGUA, DA TERRA E FLORESTA EM} PARINTINS

3.1 Escola, currículo e ensino de Geografia

3.2 As escolas: Tiradentes, no Itaboraí do Meio e Tukasa Uetsuka, na Vila Amazônia .....

3.3 Ensino seriado: águas turvas do conhecimento

3.4 Ensino multisseriado: uma aprendizagem conturbada

\section{CAPÍTULO 4 - GEOGRAFIA E CARTOGRAFIA NAS ESCOLAS DAS COMUNIDADES RIBEIRINHAS DE PARINTINS}

4.1 Geografia das quatro paredes nas escolas ribeirinhas de Parintins

4.2 Geografia na comunidade ribeirinha de Parintins: entre o risco e o rabisco do estudante 


\section{APRESENTAÇÃO}

A essência desta tese é a alma do ribeirinho amazônico. Nascido e criado na várzea e que, posteriormente, cresceu na terra firme - no caso, do município de Parintins - onde teve a oportunidade de manter contato direto com a realidade natural e social de cada ambiente, envolvendo-se com histórias, com as crendices, lendas e projeções das mentes que criaram aspectos sobrenaturais para explicar fenômenos naturais não compreendidos, geradores de respeito à floresta e aos rios.

Dentro desta realidade amazônica, este filho, da beira do rio e da várzea, navegou em águas barrentas em busca do crescimento dentro das adversidades e desigualdades sociais existentes. Na ajuda coletiva, todos participavam e se sentiam acolhidos socialmente. Na terra firme cresceu, onde o puxirum (ajuda mútua) auxiliava na construção solidária de viver em comunidade.

Grandes lições foram ensinadas a partir de pequenas ações, mesmo porque seu pai trabalhador da juta na várzea e agricultor na terra firme - não permitia que seus trabalhadores fizessem suas refeições em separado de sua família, pois todos tinham que estar sentados ao redor da mesa, em verdadeiro ato de comunhão; uma demonstração de não ver nenhum trabalhador diferente ou inferior ao próprio membro da família. Esta lição foi aprendida para saber viver com todos e não ver ou se sentir superior por causa de posses, mesmo porque antes de serem empregados eram pessoas, gente.

A mãe, dedicada às atividades domésticas, procurou ensinar a criar animais, fazer horta caseira, a casear, lavar roupa, arrumar casa, para que, quando crescesse, soubesse realizar as atividades domésticas básicas. Tanto a mãe quanto o pai sabiam ler e realizar as quatro operações matemáticas (estudaram até a $3^{\text {a }}$ série primária). Mesmo assim, a mãe sempre procurou encaminhar todos os filhos ao estudo e por isso foram à escola ribeirinha e a irmã mais velha passou a estudar em Parintins, residindo na casa de parentes e enfrentando todos os problemas possíveis.

Crescendo e aprendendo com histórias de visagem, dos guardiões da floresta e do rio aprendeu o respeito ambiental, social e cultural que se traduziram em respeito pela vida humana e respeito pelo ser humano. Assim sendo, os percursos exigiram força e esforço para, nos braços da verdade, da dignidade, poder realizar leituras críticas sobre as injustiças sociais estabelecidas pelas imposições da falta de distribuição de renda e da exploração da força de trabalho do ser humano. Outra aprendizagem veio da vivência com as diferenças culturais 
criadoras do universo de vida ribeirinha, tanto da várzea quanto da terra firme, onde a escola com sua visão deslocada da realidade - não deixava construir conhecimentos críticos, mas reproduzir o que estava pronto.

Foi estudante da escola de várzea e também da escola de terra firme, onde tinha que copiar o ponto, fazer a cópia do livro e responder as questões como estava escrito no livro, senão estaria errado. Fora da sala de aula, os conhecimentos eram adquiridos nas distâncias percorridas para ir à escola ou no retorno para casa quando observava o rio de água barrenta, tipos de vegetação, espécies de aves. Na relação familiar, aprendia-se trabalhando e, para tanto, participava do plantio e colheita da juta na várzea. Na terra firme, ajudava na plantação de roças de mandioca, canaviais e também nas coletas de frutos, resinas e óleos vegetais da floresta.

Outra importante lição estava na capacidade de aprender a sobreviver. Acompanhava os pescadores nas suas idas até o lago por inúmeros canais sob a floresta de várzea e assim construindo na mente todo o caminho percorrido para saber por ele voltar.

Todos os ensinamentos praticados na várzea e na terra firme ajudaram a refletir sobre a escola ribeirinha e o ensino de Geografia, que fazem passar horas estimulando a mente no sentido de reviver imagens do passado para compreender todas as mudanças no presente.

Então, com o propósito de estudar e trabalhar a construção de uma escola ribeirinha amazônica e da Amazônia que possa auxiliar todos os comunitários com conhecimentos construídos e ensinados aos filhos, na necessidade de se debruçar sobre estudo analítico da Escola Pedro Reis Ferreira da comunidade do Espírito Santo do Meio (várzea), do município de Parintins, desenvolveu-se a dissertação de mestrado sobre currículo e ensino de Geografia. Este estudo abriu margem para a possibilidade de descobrir a geografia do município de Parintins e também o espaço de vida dos estudantes ribeirinhos na relação ensino/aprendizagem, porque sempre se pensou em uma escola que associasse os conhecimentos formais com os conhecimentos historicamente construídos.

Neste momento em que fazia mestrado, exercia atividade como Professor Substituto na Universidade Federal do Amazonas, fato importante para aprimorar a leitura crítica acadêmica sobre a realidade vivida e experienciada. Trabalhando na Universidade, cumpriu todos os créditos com êxito e, no momento de ir a campo, foi aprovado para ser Professor contratado da Universidade do Estado do Amazonas, tendo que trabalhar no Campus da cidade de Tabatinga, fronteira com Colômbia e Peru. Em Tabatinga, voltou a ter contato com as escolas ribeirinhas de várzea e terra firme, realidade de lugar muito diferente da vivenciada 
em sua infância, mas não havia diferença entre as escolas e a forma de ensinar, estudada no mestrado, no município de Parintins.

No momento em que defendeu o mestrado, estava aprovado através de concurso público na Universidade do Estado do Amazonas para trabalhar na unidade em Manaus, mas em 2009, enquanto aguardava ser chamado a assumir a vaga do concurso, foi trabalhar como contratado no Centro da Universidade do Estado do Amazonas em Parintins, quando se submeteu ao novo concurso e obteve êxito, optou por permanecer em Parintins, desistindo da vaga de Manaus. Neste mesmo ano de 2009, foi aprovado no doutorado USP/UEA, onde cumpriu os créditos em Manaus tendo que associar trabalho e estudo. Cada leitura desta realidade de ensino na Amazônia fez aumentar as inquietações sobre a não-aceitação do ensinado em Geografia nas escolas, tornando-se isto a mola propulsora para o estudo no doutorado sobre a Geografia nas escolas das comunidades ribeirinhas do município de Parintins.

Ao realizar a pesquisa, foi percebido o quanto do aspecto primitivo aflora neste pesquisador (e assim deixa-o mais primitivo) por querer ser mais solidário e entender a importância do trabalho dialogado coletivamente, porque sem este não há ações e relações comunitárias. Assim sendo, acredita na vida em construção de si mesmo. Descobrindo com a pesquisa e ampliando o conhecimento, poderá ajudar muito mais outras vidas ribeirinhas a se reconhecerem entre as verdades e as desigualdades socioculturais e sociopolíticas com propósitos de conduzir a uma visão crítica e fomentadora de mudança da realidade existente e vivida em cada beira do rio, seja de várzea ou de terra firme.

A vontade dos estudantes ribeirinhos em aprender e compreender sua realidade, incentiva a intensificar a pesquisa, porque eles são agentes construtores de si mesmos e, diante de suas dificuldades, podem exaltar seus nomes, suas identidades e suas revoluções socioculturais e socioambientais, no exercício pleno da liberdade proporcionado pelo ensino de Geografia, na leitura e releitura crítica da realidade vivida.

O pesquisador procurou perceber a essência das relações de aprendizagem no interior da escola e nas lições diárias em suas casas a partir de um todo experienciado, para poder estabelecer critérios de estudo e assim traçar planos de pesquisa na tentativa de discutir e compreender a geografia existente na escola da comunidade ribeirinha do município de Parintins, tanto da várzea quanto da terra firme, mesmo sendo duas escolas e quatro anos de ensino do fundamental ( $6^{\circ}$ ao $9^{\circ}$ ano). Dessa forma, o Capítulo 1 - Navegando nos trajetos da pesquisa - permite realizar uma viagem panorâmica sobre o objeto pesquisado e procura 
esclarecer os percursos feitos para concretizar o objeto pensado, apresentando os lugares da pesquisa quando procurava desvendar as comunidades ribeirinhas de Parintins. Estes elementos contidos no primeiro capítulo conduzem a um mergulho nas múltiplas realidades amazônicas, deixando evidente a geografia existente em cada comunidade e a ministrada na escola. Assim sendo, estes relatos passaram a ser a propulsão para o Capítulo 2 - Construções de saberes e o lugar de vida - onde a contextualização aproxima as realidades do ensinado e aprendido - como cultura, saberes do passado vivenciados nos ensinamentos do presente, na Amazônia; construções de vida na Amazônia: o ribeirinho; lugar de vida: comunidades ribeirinhas amazônicas e terra firme e várzea. Elementos fundantes para discutir o currículo, os saberes tradicionais e o cotidiano, no sentido de compreender a tensão existente no processo ensino-aprendizagem de Geografia, nas escolas ribeirinhas.

Seguindo os meandros inquietantes de compreensão da geografia na escola de comunidade ribeirinha, o Capítulo 3 - Escola da água, da terra e floresta em Parintins verticaliza o olhar sobre a escola, currículo e ensino de geografia; ensino seriado e águas turvas do conhecimento; ensino multisseriado, ensino modular como nova proposta para a escola de várzea de Parintins e Menino Deus - Itaboraí do Meio e Santa Maria - Vila Amazônia. Estes temas são cruciais para o entendimento da realidade amazônica pesquisada, onde a escola da água, assim pensada porque vive a sazonalidade do rio Amazonas, levando o ribeirinho à adaptação de viver mais na água do que na terra. Já a escola da terra e floresta está intimamente ligada a terra firme e sua exuberante floresta. Tanto um ambiente quanto o outro são detentores de singularidades e podem ser grandes laboratórios de construção de conhecimentos, onde tudo pode representar base de experimentação novas metodologias de ensino-aprendizagem em geografia. O sentido é de aproximação dos saberes formais com os saberes não formais vividos e concebidos por todos os sujeitos envolvidos na aprendizagem cotidianamente.

Mergulhando nas profundezas da geografia ribeirinha escolar, o Capítulo 4 Geografia nas escolas das comunidades ribeirinhas de Parintins - aborda pontos primordiais como a geografia das quatro paredes nas escolas ribeirinhas; geografia na comunidade ribeirinha amazônica entre o risco e o rabisco do estudante; aprendendo com o saber tradicional e possibilidades didáticas para ensinar Geografia. Aspectos demonstrativos dos conhecimentos adquiridos na escola e na vida cotidiana dos estudantes, a partir da representação geográfica do lugar de vida; os recursos naturais existentes em cada comunidade passaram a ser demonstrados como recursos didáticos para exercitar a 
imaginação no processo de construir compreensões sobre a geografia. Assim, o conhecimento geográfico poderá auxiliar na leitura da realidade vivida e tornar-se parte integrante do desenvolvimento socioeconômico, sociocultural, socioambiental e sociopolítico dos comunitários. Por fim, a conclusão faz relação entre teoria e prática, real e abstrato, geral e particular, permitindo perceber a viabilidade de unir a geografia da escola com os conhecimentos tradicionais ribeirinhos, eliminando o fosso existente - porque há possibilidade de aprimorar o currículo para que o estudante possa conhecer geograficamente seu lugar de vida e assim fortalecer sua identidade cultural em dinâmico exercício de cidadania dentro das adversidades sociais e culturais, posicionando criticamente frente à realidade em sociedade. 


\section{CAPÍTULO 1 - NAVEGANDO NOS TRAJETOS DA PESQUISA}

Este capítulo reúne informações sobre a geografia nas escolas das comunidades ribeirinhas, no sentido de mostrar os caminhos seguidos e adotados para definir o lugar da pesquisa. O lugar está cheio de saberes e contém todo processo educativo, tanto escolar como cotidiano, possibilitando dimensionar a geografia aprendida pelos estudantes na sua vivência diária e nas relações coletivo-comunitárias de aprendizagem em espaços formais e não formais.

O processo de condução da pesquisa exigiu planejamento logístico nas atividades desenvolvidas no período de Maio de 2010 a Maio de 2012. O início das atividades ocorreu com a realização de inúmeras viagens por vários municípios até especificar, com exatidão, o objeto pesquisado no município de Parintins. As viagens para e pelas comunidades ribeirinhas de Parintins foram repletas de aventura e muita coragem, primeiro por ter hora certa para navegar pelo rio Amazonas - sentido oeste/leste, uma vez que, ao perder o horário tornar-se-ia difícil enfrentar as grandes ondas do rio, impossibilitando assim chegar até ao lugar da pesquisa.

Estas viagens foram importantes para o contato com as pessoas das comunidades e estudantes das escolas porque, através de suas falas, foi possível experimentar os seus sentimentos, suas batalhas diárias nas comunidades, seu trabalho no roçado - cavando o solo para plantar esperanças de dias melhores - e conhecer o lugar de vida e de realizações pessoais, socioculturais e sociopolíticas.

Tudo que foi observado nas viagens pelas comunidades serviu para estabelecer parâmetros e bases de reflexão sobre a geografia nas escolas das comunidades ribeirinhas: entre o currículo, o cotidiano e os sabres tradicionais, deixando de ser uma pesquisa de aplicação. 


\subsection{Desvendando as comunidades ribeirinhas de Parintins}

A Amazônia é um lugar de múltiplos fenômenos físicos e sociais, bastantes complexos, que dificultam um estudo na sua totalidade. Para realizar o estudo apresentado nesta tese, foi preciso reduzir o universo em partes, porque em cada parte há uma totalidade. Por isso, passou-se a estudar apenas dois lugares no município de Parintins: a comunidade de Menino Deus - Itaboraí do Meio, onde se encontra a Escola Tiradentes, na margem esquerda do rio Amazonas, área de várzea; o outro lugar escolhido foi Vila Amazônia, escola Tukasa Uetsuka, área de terra firme.

O estudo partiu da perspectiva do pesquisador por ser um ribeirinho migrante de comunidade de várzea do município de Parintins e por conduzir, dentro de si, toda história de vida e as múltiplas relações do lugar vivido, tanto da várzea (São Manuel - Arari) quanto da terra firme (São Tomé - Mocambo), lugares pertencentes ao município de Parintins, intimamente ligados à escola ribeirinha.

No contexto pretérito, a oportunidade de iniciar a compreensão do mundo, fazendo leituras simples da realidade vivenciadas pelas observações e o aprendido nos ensinamentos e orientações dos mais velhos (pais, tios e avós), conduziram a tentar entender as abstrações (fenômenos naturais) representadas nas crendices ou mitos amazônicos (terras-caídas, na várzea, estão associadas ao movimento da cobra grande; a floresta guarda no seu interior o curupira, que representa o ser ou a entidade protetora dos animais). Estes fenômenos eram expostos através de histórias contadas nas rodas de conversas sobre as crendices e sobre os mitos amazônicos, aflorando o imaginário de quem escutava e com isso faziam crescer curiosidades no sentido de desvendar os mistérios que eram apresentados, mas também desprendia respeito pelo desconhecido, seja do fundo rio ou do meio da mata. Este tipo de ensinamento ainda é transmitido pelos pais aos seus filhos, percebido em momentos de diálogos nas residências visitadas, durante a pesquisa de campo.

Estes primeiros ensinamentos foram preparações para viver a sazonalidade do rio Amazonas ou para se proteger na terra firme dos perigos nela guardados. Por isso, a transmissão de conhecimentos nas comunidades ribeirinhas amazônicas, vem sendo passada de geração a geração, ocorrendo, principalmente, mediante formas de ajudar aos pais nas atividades agrícolas, nas pescarias, nas caçadas e nas atividades domésticas do lar. $\mathrm{Na}$ várzea, havia - e ainda há - o ensinamento do plantar culturas de ciclo rápido, sabendo o arranjo espacial das espécies vegetais. A partir destes ensinamentos diários e tradicionais, 
aprendia-se a contar histórias de antepassados e descobria-se detalhes que encobriam aquele universo falado, cheio de mistérios, despertador do imaginário de quem escutava; o ir e vir aos lagos, igarapés, sem medo de se perder, porque o senso de orientação já estava trabalhado no todo experienciado. As histórias dos antepassados eram algo que precisava ser desvendado para ser compreendido como significado e herança cultural do lugar. Porque, no lugar, sempre há a parteira, o curandeiro - que utilizavam as ervas medicinais, as cascas de pau, as resinas vegetais e óleo de andiroba, copaíba e outros produtos naturais para praticar a cura, despertando curiosidade e questionamento, principalmente de como sabiam a dosagem certa da mistura feita como remédio. Isto tudo presente na comunidade e onde a escola se encontrava e se encontra, sem, contudo, aproximar e utilizar estes saberes nos ensinamentos escolares.

A escola se apresentava como um ambiente rústico, assoalho de madeira, palafita (construção feitas sobre troncos, estacas ou esteios), coberta de alumínio. As mesas de estudos eram coletivas (mesas de tábuas compridas e bancos grandes) em que os alunos ficavam prontos para estudar, com seus cadernos (papel almaço, costurado) para anotar o que era ensinado (hoje, o espaço escolar é muito diferente, mais equipado, mesa do professor e carteira individual para o estudante, armários para guardar material didático; em algumas comunidades luz elétrica; mesmo sendo em palafita na várzea e/ou alvenaria na terra firme), o espaço escolar descrito é um verdadeiro campo de conteúdo a ser explorado didaticamente. Porém, estes saberes do espaço formal não tinham muita coisa a ver com que era aprendido com os pais e avós nos espaços não formais. O quadro apresentado deixa perceptíveis as duas realidades que não conseguiam e, ainda hoje, não conseguem manter certa harmonia no processo de formação do estudante, pois os conhecimentos aprendidos na escola não permitiam e ainda não permitem certa utilidade nas práticas exercidas nas pescarias e no trabalho do roçado - seja no plantio da juta, da mandioca, das hortaliças e/ou na criação de animais; e assim, os conteúdos aprendidos na escola não eram e continuam não sendo a base de suporte para os conhecimentos aprendidos nas transmissões práticas do dia-a-dia, seja no roçado ou nas pescarias.

Então, pela preocupação dos filhos terem sempre o melhor em termos de ensino, os pais migravam da comunidade ribeirinha amazônica para o urbano, na tentativa de proporcionar um novo estudo e novas oportunidades para vida. Porém, quando o estudante migrante chegava - e ainda chega à cidade - deparava-se com outra realidade escolar porque tudo que tinha apreendido em sua comunidade de origem não era valorizado - e ainda visto 
como atrasado (o estudo da escola ribeirinha, seja de terra firme ou várzea, é considerado como fraco; e ainda hoje, é visto desta maneira: fraco e atrasado). A discrepância já tinha sido observada entre os dois tipos de aprendizado experienciados e ficava cada vez mais evidente o contraste e o distanciamento entre o formal (escolar) e o não-formal (não-escolar). Na cidade, muitos dos ensinamentos obtidos a partir do proposto pela família, foram se perdendo ao longo dos anos pelo contato com novas realidades - principalmente a tecnologia modificando significativamente o sentimento de identidade, onde a herança do modo de vida da várzea ou da terra firme, do meio não urbano, foi e vai aos poucos dando espaço ao modo de vida urbano. Isto não quer dizer que o estudante não possa experimentar mudanças - pode e deve - até porque os grupos sociais vivem acompanhando o ritmo acelerado das mudanças nacionais e globais, como já ocorre nas próprias comunidades: o contato com tecnologias como internet, celular de última geração... O que não se pode, e não se deve, é negar sua origem, muito menos sua identidade cultural ribeirinha. A escola das comunidades ribeirinhas amazônicas deve exercitar e fortalecer todo um conhecimento existente, aprendido e trazido para a escola e assim enriquecer o conhecimento formal trabalhado em sala de aula.

A trajetória conturbada de estudante ribeirinho e migrante na cidade foi transformada neste documento de tese. Assim sendo, na condição de migrante, surgiu a preocupação em desenvolver a acurada pesquisa para refletir a respeito da possibilidade de aproximar o saber geográfico das escolas das comunidades ribeirinhas, existente no currículo, no cotidiano, nos saberes tradicionais, no sentido de fortalecer a compreensão de lugar, a partir dos matizes, das representações histórico-espaciais e das relações socioculturais.

Assim sendo, o tema desta tese tem também a pretensão de suscitar reflexões e discussões sobre a geografia existente na comunidade e não estudada na escola, porém vivida diariamente por todos os estudantes no seu ir e vir constante para a escola ou por suas andanças normais do ver a malhadeira (rede de pesca) ou no pular na água, demonstrando a liberdade vivida. Isto reflete a contradição que há no processo do ensino escolar e dentro deste o ensino de geografia aprendido na sala de aula, porque, não considerando a geografia existente na comunidade, nega o valor do aprendido com os ensinamentos dos pais e avós, quando não se apodera destes saberes para enriquecer a geografia ensinada.

É importante salientar que o estudante aprende cotidianamente muito pela curiosidade que possui e, ao mesmo tempo aperfeiçoa e aguça sua criatividade, a qual não sendo estimulada na sala de aula, poderá ser bloqueada quando os conhecimentos formais desconhecem e não aceitam o conhecimento pré-construído. Estes saberes adquiridos pelos 
estudantes são constructos social e coletivo, aprendido em rodas de conversas, histórias de visagem, nas brincadeiras e até mesmo no simples ato de se banhar no rio. Esta forma de ver o que os estudantes ribeirinhos aprendem, está intimamente ligado aos ensinamentos de Paulo Freire (1996, p. 30-31)

Por isso mesmo pensar certo coloca ao professor ou, mais amplamente, à escola, o dever de não só respeitar os saberes com que os educandos, sobretudo os das classes populares, chegam a ela saberes socialmente construídos na prática comunitária mas também, como há mais de trinta anos venho sugerindo, discutir com os alunos a razão de ser de alguns desses saberes em relação com o ensino dos conteúdos. Por que não aproveitar a experiência que têm os alunos de viver em áreas da cidade descuidada pelo poder público para discutir, por exemplo, a poluição dos riachos e dos córregos e os baixos níveis de bem-estar das populações, os lixões e os riscos que oferecem à saúde das gentes. Por que não há lixões no coração dos bairros ricos e mesmo puramente remediados dos centros urbanos? Esta pergunta é considerada em si demagógica e reveladora da má vontade de quem a faz. É pergunta de subversivo, dizem defensores da democracia.

Por que não discutir com os alunos a realidade concreta a que se deva associar a disciplina cujo conteúdo se ensina, a realidade agressiva em que a violência é a constante e a convivência das pessoas é muito maior com a morte do que com a vida? Por que não estabelecer uma "intimidade" entre os saberes curriculares fundamentais aos alunos e a experiência social que eles têm como indivíduos? Por que não discutir as implicações políticas e ideológicas de um tal descaso dos dominantes pelas áreas pobres da cidade? A ética de classe embutida nesse descaso? Porque, dirá um educador reacionariamente pragmático, a escola não tem que ver com isso. A escola não é partido. Ela tem que ensinar os conteúdos, transferi-los aos alunos. Aprendidos, estes operam por si mesmos.

Então, este ensinamento de Freire abre espaço de diálogo sobre o medo imposto ou o medo existente no ato de ensinar, o medo de romper o que está posto como verdade absoluta e o medo de ser cobrado pelo não cumprimento da proposta de conteúdo, estabelecido como currículo pela Secretária de Educação. Então, o conhecimento adquirido diariamente fora da escola ainda está distante de ser complemento ou parte integrante do conteúdo ensinado na sala de aula. Os estudantes continuarão aprendendo na convivência e com a experiência a geografia vivida e experimentada diariamente no rio, na mata, no lago, na agricultura, na criação de animais ou no descanso em seu barraco de palha, madeira ou alvenaria.

Apesar do olhar de Freire ser voltado para uma realidade urbana, encaixa-se no que a escola deixa de fazer, seja no urbano, campo ou nas comunidades ribeirinhas da Amazônia. Por isso é bastante pertinente à discussão sobre o que está sendo ensinado na escola.

Dessa forma, o tema refletido nesta tese, advindo da pesquisa, tem como referencial teórico o conceito de lugar, discutido em Manrandola Jr., Holzer e Lívia de Oliveira (2012) sem, contudo, perder o diálogo sobre currículo, cotidiano e saberes tradicionais ou historicamente construídos, porque estão contidos e contém o lugar, construindo fundamentos para apoderar-se do processo ensino - aprendizagem, na compreensão da escola ribeirinha 
como transformadora e construtora de cidadanias. Além das discussões supramencionadas este tema tem, ainda, por base focal, o estudo da possibilidade de aproximar o currículo dos saberes tradicionais, no sentido do que é aprendido pelos estudantes ribeirinhos representando a base fortificadora de sua identidade cultural e reconhecimento do grau de importância de seu lugar de vida.

\subsection{Justificativa}

O ensino de geografia é um desafio para o professor das escolas ribeirinhas por se sentir impotente diante do surgimento de determinadas dificuldades do processo ensinoaprendizagem ou por não saber fazer a transposição do conhecimento acadêmico para o conhecimento escolar. Esta dificuldade distancia a geografia ensinada da geografia vivida diariamente pelo estudante ribeirinho.

Esse estudante navega pelas estradas fluviais da Amazônia, principalmente, do estado do Amazonas, observando a circulação de vidas, da economia, de esperanças, de sentimentos e, em particular, encontrando-se com quem procura descobrir para entender a complexidade desta região amazônica, seja através da geografia das escolas das comunidades ribeirinhas ou através dos conhecimentos tradicionais existentes.

Neste percurso de reflexão, depara-se com os desafios do professor da escola que tem procurado alternativas para dar sentido e significado aos conteúdos ensinados, tornando-os mais úteis na vida de quem precisa colocá-los em prática. Mesmo assim, os conteúdos geográficos ensinados não aproximam os saberes tradicionais e não auxiliam na decifração da complexidade amazônica.

Essa complexidade está presente em cada curva do rio (meandro), em cada erosão fluvial ou em cada terreno formado por deposição sedimentar (este último passa a ser elemento de conflito, porque alguém vai se manifestar como proprietário do depósito sedimentar - praia, estendendo a cerca até a beira do rio). Pode estar também na margem dos rios, nas paisagens naturais e antrópicas, demonstrando a relação que há entre o ser humano e o meio natural, não como elementos distintos, mas como uma teia de possibilidades do viver e morar, do tirar e plantar para existir, do ensinar para aprender a ter sempre. Estes sentimentos de pertencimento e de apoderamento deixam evidente a complexidade sobre o lugar e no lugar de vida, ficando demonstrada a possibilidade de construir compreensão de si mesmo, dentro do vale amazônico, mesmo porque 


\begin{abstract}
Entre os primeiros povos e nos meios populares das sociedades tradicionais, as geografias não são exclusivamente feitas de práticas e de habilidades. Elas são carregadas de experiências e de subjetividade. Viver é evoluir entre as paredes ou se encontrar ao ar livre. Viver é estar em contato com o meio ambiente em todos os sentidos: com a visão, a audição, o olfato, o tato. É se mover em um ambiente selvagem, cultivado ou urbanizado, é percebê-lo enquanto paisagem. As pessoas têm uma reação emotiva diante dos lugares em que vivem, que percorrem regularmente ou que visitam eventualmente. Alguns lhes agradam, lhes parece agradáveis, acolhedores ou calorosos; outros os seduzem por sua beleza, pela impressão de calma e de harmonia que deles emana ou pela força das emoções que eles suscitam. Há em contrapartida paisagens quaisquer, banais, sem interesse; nós as atravessamos sem que nada chame a nossa atenção: é difícil descrevê-las ou caracterizá-las! Em outros lugares a feiura, a sujeira ou o mau cheiro provocam a repulsa no visitante. Este é às vezes tomado por um sentimento de ameaça: a insegurança parece estar onipresente, um perigo pode surgir a qualquer instante, uma agressão é sempre possível. (CLAVAL, 2010, p. 39 - grifo nosso).
\end{abstract}

Assim sendo, as realidades amazônicas traduzem a necessidade de compreender a complexidade manifestada em cada observação feita ou tentar demonstrar a singularidade ou particularidade de cada lugar da pesquisa em A Geografia nas Escolas das Comunidades Ribeirinhas de Parintins: entre o currículo, o cotidiano e os saberes tradicionais. Tema que instiga não só uma aproximação, mas o envolvimento para refletir o cotidiano, o saber tradicional e toda geografia existente nas comunidades ribeirinhas.

Tal constatação despertou interesse em adentrar nesse universo escolar por perceber a vontade dos professores em aplicar um ensino de qualidade para que os estudantes possam planejar suas vidas futuras. Assim, surgiu a ideia da pesquisa no sentido de consolidar ideias, propostas metodológicas ou possibilidades diferentes de ensino de geografia, que possam sanar as lacunas existentes, explorando a criatividade do estudante para se apoderar do seu lugar de vida, sendo este o lugar da pesquisa.

O lugar da pesquisa são comunidades simples escondidas nas matas de várzea ou de terra firme, mas visíveis na beira do rio, mantendo e demonstrando a simplicidade dos seus moradores e construtores de sua organização espacial. Estas comunidades, apesar de existirem em toda vastidão amazônica com suas particularidades e singularidades, guardam memórias de seu processo construtivo, e, assim, o estudo se concentrou somente no município de Parintins e neste apenas em duas comunidades: a de Itaboraí do Meio - Menino Deus (distante da cidade, em média $10 \mathrm{~km}$ ), encontra-se sob a várzea e na margem esquerda do rio Amazonas e a comunidade de Santa Maria de Vila Amazônia, encontrando-se sobre terra firme (distante da cidade, em média $3 \mathrm{~km}$ ). Estas comunidades selecionadas para pesquisa permitiram uma análise da realidade do ensino de geografia existente na escola ribeirinha, até 
para melhor compreender a tensão existente entre os conhecimentos propostos no currículo de geografia e os saberes tradicionais ensinados aos estudantes. As características existentes nas escolas e comunidades estudadas não são apenas do município de Parintins mas de todas as comunidades de outros municípios do Estado do Amazonas, por possuírem as mesmas características e complexidades.

Estas complexidades se encontram na maneira ou na forma do trabalho educacional realizados nas escolas ribeirinhas, tendo que seguir as orientações repassadas pelos superiores ou orientadores pedagógicos, que passam periodicamente na escola - não como auxiliadores de mudanças ou de apresentação de algo novo, mas como fiscalizadores educacionais. Não é percebida a ousadia de se fazer diferente ou de se criar proposta diferente de ensinar na escola ribeirinha, apesar de existir um verdadeiro laboratório de saberes geográficos amazônicos, como a simples e própria localização do município de Parintins (Mapa 1), na intrincada malha fluvial e de todo composto arquipélago existente a ser decifrado na e pela escola aos estudantes.

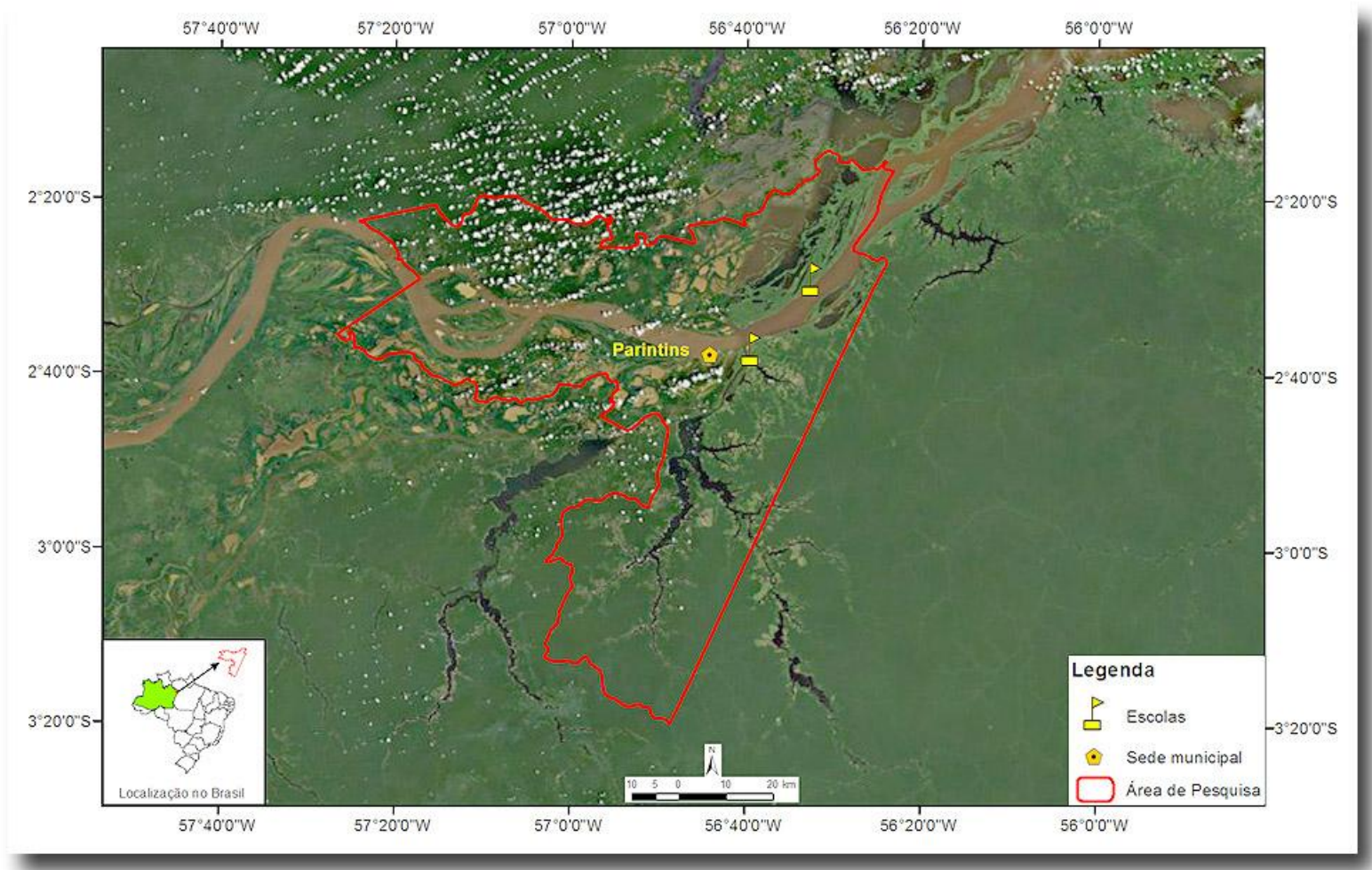

Mapa 1 - Localização do município e da cidade de Parintins Organizado por Willer Pinto - set/2010 
Este município foi selecionado por apresentar características diferentes de localização e até mesmo dos ambientes naturais e socioculturais. A cidade de Parintins localiza-se na margem direita do rio Amazonas, e, o município faz fronteira com o Estado do Pará.

As comunidades foram selecionadas partindo de características socioambientais (mapa 2). A comunidade Menino Deus do Itaboraí do Meio, por estar localizada na margem esquerda do rio Amazonas e por viver a sazonalidade do rio (enchente e vazante), estando distante da cidade. A comunidade de Santa Maria de Vila Amazônia por se localizar na margem direita, por estar sobre o ambiente de terra firme e próxima da sede do município. Guarda em si a história de ocupação e transformação do espaço por japoneses (década de 1930 - século XX) e portugueses (década 1950 - século XX). Por estas características é de suma importância este estudo até mesmo para verificar o distanciamento entre os saberes geográficos ensinados na sala de aula em relação e saberes tradicionais aprendidos e repassados historicamente. $\mathrm{O}$ ensino de geografia se associado a toda geografia vivenciada diariamente poderiam significar a relevância para o sentimento de identidade dos estudantes destas duas comunidades.

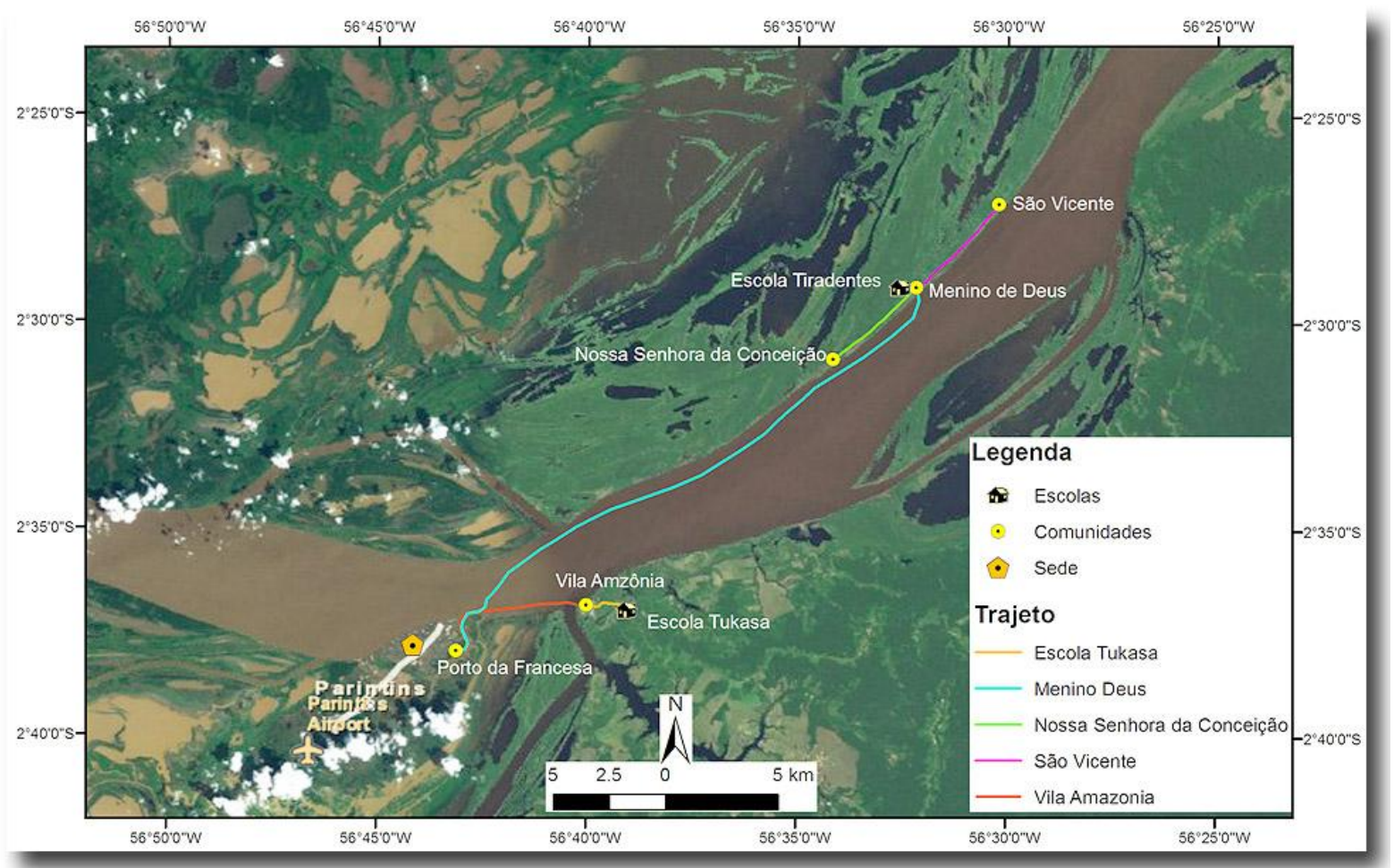

Mapa 2 - Localização das comunidades - lugares da pesquisa Organizado por Willer Pinto - Maio/2012 
Cada comunidade possui dinâmicas do morar e do viver diferentes, mesmo que estejam na várzea ou na terra firme, próximas ou distantes das cidades, apresentadas nas resistências do pertencimento dos habitantes, tendo como influência a floresta ou água. Cada foco de resistência está em cada sujeito, porque cada um possui dentro de si o lugar, a comunidade, a floresta, rios e lagos; possui a geografia do viver e do existir, até porque se sente parte integrante do sistema.

Esta geografia do viver está nas representações de lugar e neste há as manifestações socioculturais de pertencimento em que é possível perceber a totalidade da Geografia nas Escolas das Comunidades Ribeirinhas do município de Parintins, a partir dos múltiplos matizes de cada comunidade. Esta Geografia não é vista no currículo de geografia presente nas escolas, mas existe de forma vivida, percebida e concebida, portanto, conhecida e ensinada pelos pais aos seus filhos estudantes das escolas ribeirinhas (saberes construídos coletiva e historicamente). Pode-se dizer que a geografia do lugar e do cotidiano, aprendida e ensinada fora da escola, deveria ser o caminho para entender o lugar e assim exercitar os conceitos de Geografia, para fortalecer o conhecimento local, possibilitando uma interligação com nacional e o global.

Atualmente, imbricando a problemática por um universo mais abrangente e complexo, é percebido que, devido aos grandes avanços ocorridos nos diferentes segmentos sociais, principalmente, à era da informação, as instituições de ensino foram forçadas a sofrer mudanças significativas, tanto no âmbito funcional, quanto nos seus mais diferentes fundamentos do processo escolar com a finalidade de atender às novas tendências e exigências surgidas no mercado ou na sociedade. Decorrente disto surgiu uma postura diferenciada no processo de ensino-aprendizado, que não pode ser mais concebido a partir da perspectiva do conteúdo, servindo apenas para quantificar e mensurar um determinado atributo capaz de caracterizar um momento esporádico e oportuno de aprendizagem na história de um indivíduo. O ensino deve ser o gerador de bem estar e de qualidade do viver, em qualquer lugar. Então, tudo que a comunidade produz e possui pode ser fonte de conteúdo a ser estudado e associado ao conhecimento já construído de geografia ensinado na sala de aula. 
Como era antes? A escola era um prédio rústico, todo aberto. Os bancos longos e mesas compridas onde todos os alunos sentavam. Nos anos 1980 foram adotadas cadeiras individuais, saindo do modo coletivo de aprendizagem. Os conteúdos eram repassados dos livros diretamente para o caderno do estudante, o qual deveria decorar tudo que fosse possível como mecanismo de aprendizagem. Apesar de haver exigência de mudança, ainda permanece o ensino deslocado da realidade vivida.

Decorrente do panorama descrito e de acordo com os novos paradigmas educacionais e da própria Geografia, o ser humano necessita aprender a aprender em um processo contínuo, para compreender o lugar em que vive e assim ler e reler sua realidade local, regional, nacional e até global. Esta forma de pensar esta alicerçada em Paulo Freire (1996, p.24) “[...]. É que em o processo de aprender, em que historicamente descobrimos que era possível ensinar como tarefa não apenas embutida no aprender, mas perfilada em si, com relação a aprender, é um processo que pode deflagrar no aprendiz uma curiosidade crescente, que pode torná-lo mais e mais criador”. Dessa forma, todas as suas ações, tanto no aspecto cognitivo ou domínio dos modos de produção do saber em sua respectiva área, quanto na formação de seu caráter devem estar passando por uma constante mudança, com a finalidade de buscar a excelência nas diferentes relações a serem estabelecidas consigo próprio, com o outro e com o mundo, através de parcerias com grupos sociais em seu contexto de interação. Isto tudo pode ser materializado em formas de mapas ou pequenos croquis, produzidos na sala de aula ou na comunidade, tendo como referência os conhecimentos adquiridos com a geografia escolar e com todas as informações veiculadas pelos meios de comunicação de massa que chegam às comunidades, associados aos conhecimentos adquiridos cotidianamente nos ensinamentos de seus pais.

Na condição de migrante ribeirinho e educador (professor de Geografia), ao associar estas inquietações pessoais descritas anteriormente com a complexa realidade vivida atualmente tanto nas andanças pelas comunidades ${ }^{1}$ ribeirinhas amazônicas, tem-se a pretensão

\footnotetext{
1 Aqui se apodera do termo "comunidade" do que é popularmente utilizado e também foi termo estabelecido quando a Igreja Católica fixou o santo no lugar (o santo não pertencia a um lugar e sim peregrinava de casa em casa até o dia da festa do santo e o dono da casa passava a ser o responsável pelo festejo e alimentação de todos os convidados). Não se tem a pretensão de fazer uma discussão do termo "comunidade" tanto do ponto de vista sociológico, muito menos antropológico, assim como não se pretende questionar a forma de organização que se deu com a criação de comunidades rurais de várzea e terra firme, como são chamadas. Em todo percurso da tese não será utilizado o termo comunidade rural, mas sim, comunidades ribeirinhas amazônicas ou somente comunidade ribeirinha, mesmo para aquelas comunidades que se encontram a $15 \mathrm{~km}$ ou mais da margem do rio principal (a comunidade pode estar na margem de um pequeno rio, conhecido como igarapé). Os moradores mantém a mesma relação como se tivessem na margem do rio principal utilizando a água, capturando pequenos peixes e outras fontes de alimento. Usam a água do rio ou do igarapé para suas práticas pessoais, como asseio corporal - onde tomam banho, para o fazer dos alimentos, para regar as plantas, para saciar a sede.
} 
de tentar aproximar o conhecimento geográfico dos saberes tradicionais ainda mais latentes entre o que é proposto pelo currículo oficial de geografia adotado nas escolas ribeirinhas das comunidades de várzea e terra firme do município de Parintins e o que é desenvolvido pelos educadores, em suas práticas pedagógicas.

Dado o exposto, é necessário que os sujeitos sociais em questão, que naquele contexto protagonizaram suas histórias, legitimem suas identidades como ribeirinhos que precisam, não só protagonizar suas histórias isoladamente, mas também relacioná-las com a história de suas origens, para fortalecer a leitura crítica da realidade vivida e questionar as imposições estabelecidas ao ensino pelo Estado. Um procedimento capaz de levar àquela prática a um desenvolvimento de estudos - tais quais quer se desenvolver - podendo associar tudo que foi aprendido no exercício diário com pais, com os conteúdos estudados na sala de aula, capazes de levar todos os sujeitos sociais envolvidos a refletir sobre o que fazem, como fazem e por que fazem, para que possam repensar os tipos de protagonismos que estão exercendo a partir do ensino geografia.

Ademais, acredita-se numa perspectiva mais abrangente desta pesquisa cujos resultados podem contribuir como diretrizes norteadoras para traçar políticas públicas voltadas à adequação ou criação de propostas de ensino centradas nas reais necessidades e expectativas daquelas comunidades ribeirinhas amazônicas, no que diz respeito principalmente ao ensino de Geografia, até mesmo para saber o que é ensinado, como é ensinado e para que é ensinado.

Vale salientar quão foi importante o uso dos conhecimentos cartográficos na pesquisa para se fazer o registro da realidade e das relações socioculturais de cada comunidade. E também para compreender os riscos e rabiscos dos estudantes das escolas pesquisadas. Dessa forma, cada lugar passará a ser decifrado e compreendido pelos sujeitos da educação e ao mesmo tempo estará se construindo um saber geográfico mais completo, responsável pelo conhecimento e pela defesa da Amazônia. Este conhecimento geográfico terá que ter utilidade prática na vida de cada estudante para que possa ressignificar o aprendido diariamente. 


\subsection{Objetivos, Hipótese e Questões Norteadoras}

As realidades apresentadas anteriormente estão vivas e muito presentes no imaginário do pesquisador, que despertaram novas leituras, novas inquietações e questionamentos sobre a Geografia existente nas Escolas das Comunidades Ribeirinhas, tanto as aprendidas no fazer diário quanto às processadas em sala de aula ou entre as quatro paredes, servindo de impulso para refletir sobre o currículo, o cotidiano e os saberes tradicionais a partir de momentos de longas conversas, trocas de ideias, rodas de diálogo com pais, professores e alunos. Estes contatos e convivências conduziram às tentativas de compreensão dos múltiplos desafios enfrentados pelos professores, alunos e toda equipe que compõe a escola, do processo ensino e aprendizagem. O pesquisador, também como observador e participante de determinadas atividades, esteve e está envolvido em pensar possibilidades de propostas condutoras de associação entre os saberes curriculares e os tradicionais, que possam ser bases condutoras de compreensão do lugar e também de mostrar que a aprendizagem não ocorre só na sala de aula, mas em todas as práticas cotidianas exercitadas pelos estudantes em suas práticas diárias, além de mostrar aos professores a riqueza de recursos que podem ser utilizados didaticamente, existentes na comunidade e no entorno da escola. Assim, os próprios estudantes vão decifrar seu lugar de vida, vão valorizar cada vez mais o seu viver e seu morar e sua história de vida ribeirinha.

Sendo assim, um olhar abrangente, procura dimensionar a realidade de cada comunidade estudada para estabelecer padrões de reflexão sobre o ensino de geografia e a geografia existente e vivida nas comunidades ribeirinhas. O objetivo principal: estudar a geografia nas escolas e das comunidades ribeirinhas, sendo uma de várzea e uma de terra firme, para refletir sobre a articulação entre o currículo, o cotidiano e o saber tradicional preexistente na história de vida dos estudantes que frequentam as escolas ribeirinhas do município de Parintins, evidenciando os tipos de efeitos que geram nos seus matizes e nas suas representações sociais, culturais e históricas do lugar.

Neste universo ribeirinho só foi possível adentrá-lo usando a relação multirreferencial, como método, para perceber o proposto no currículo, as relações do cotidiano e os saberes tradicionais vivenciados pelos respectivos protagonistas sociais, estudantes e professores, no sentido da percepção dos detalhes de toda relação praticada na escola, no roçado ou pescaria e nas lições diárias dialogadas na mesa do café, no almoço ou no jantar. 
Nesta relação de convivência a geografia existe na dimensão do lugar como processo de combinação de fatores sociais, econômicos e culturais, fortalecendo a identidade do estudante ribeirinho, por se sentir pertencente à várzea ou a terra firme.

Assim, foi possível pensar na totalidade a partir da particularidade. Isto permitiu traçar objetivos específicos para descrever o contexto amazônico, ressaltando as especificidades do município de Parintins tal como as múltiplas manifestações culturais documentadas referentes às escolas das comunidades ribeirinhas. Também, analisar como o currículo, o cotidiano e os saberes tradicionais ganham sentido a partir das múltiplas formas em que os estudantes representam aquele lugar. Fez-se necessário avaliar o atual contexto escolar: currículo, formação do professor, escola, os recursos didáticos disponíveis, o calendário escolar, número de aluno por sala e classe multisseriada, no sentido da caracterização de aspectos que podem interferir na aproximação do currículo com os saberes tradicionais. Para fechar este olhar de percepção foi preciso desenvolver estratégias didáticas que expressem e sintetizem a proposta metodológica do trabalho escolar a partir das folhas dos vegetais, aproximando das atividades cotidianas para a construção de mapas mentais, tendo como base alguns mapas e globo para cartografar, de diferentes formas, o lugar de vida dos estudantes ribeirinhos.

Considerando-se que as escolas ribeirinhas do município de Parintins possuem características que evidenciam representações de um lugar e procuram, por conseguinte, evidenciar uma perspectiva territorial peculiar àquele contexto, faz-se a seguinte problematização: é possível fazer a articulação entre currículo e os saberes tradicionais que fazem parte da história de vida dos estudantes que frequentam as escolas ribeirinhas no município de Parintins e, ainda, que tipo de efeitos são gerados nas suas representações sociais, culturais e históricas de lugar.

Na perspectiva de encontrar respostas ao problema, propôs-se a seguinte hipótese:

a história de vida dos estudantes da escola ribeirinha são reflexos de ensinamentos articulados de geração a geração e dos conhecimentos provenientes do currículo ensinado nas escolas, e assim sendo, é possível aproximar o currículo ou a geografia escolar dos saberes tradicionais para que os estudantes possam ressignificar os conteúdos aprendidos, ressignificando o seu modo de vida ribeirinho. 
No processo de melhor aprofundar o olhar no percurso da pesquisa foram estabelecidas questões norteadoras para auxiliar na reflexão e decifração do objeto pensado e pesquisado:

- Por que a escola ribeirinha não problematiza o ensino de geografia para dinamizar a aprendizagem dos estudantes e a compreensão do seu lugar de vida?

- Por que não se trabalha o currículo como processo ou programa de construção de vida, utilizando-se dos saberes tradicionais e das relações cotidianas para ensinar geografia na escola ribeirinha?

Estas questões norteadoras contribuíram na visualização das particularidades e singularidades existentes nos lugares selecionados onde se desenvolveu a pesquisa, ou seja, a Escola Tiradentes pertencente à comunidade de Menino Deus - Itaboraí do Meio, e, a escola Tukasa Uetsuka pertencente à comunidade de Santa Maria de Vila Amazônia. Nestas duas escolas toda atividade de pesquisa envolveu as turmas do sexto ao nono ano de ensino fundamental, uma turma de cada série, envolvendo em média 200 estudantes.

Desta forma, procurou-se ter maior compreensão sobre a tensão que há entre o ensinado na escola ribeirinha, o aprendido no cotidiano e com os saberes tradicionais, tão próximos, mas ao mesmo tempo tão distantes. Abre-se o fio condutor para percepção da construção do conhecimento geográfico apresentado na sala de aula e sua importância e aplicação nos fazeres diários dos estudantes das escolas ribeirinhas, no construir e reconstruir do seu modo de vida, ressignificando sempre os aspectos culturais e as construções de seus bens materiais, presentes em todas as suas práticas sociais na comunidade.

Assim, esta caminhada de leitura e releitura da geografia enquanto processo articulador e impulsionador de compreensão do todo na parte, pode representar a chave de leitura pelo estudante de sua realidade, tendo base para ter postura crítica e questionadora de todo processo que o envolve na escola e na comunidade. 


\subsection{Lugares da Pesquisa: uma indefinição definida}

As áreas da pesquisa passaram por várias visitas e análises para ser definida. Até porque, todo processo de escolha e construção do objeto de pesquisa representou (ou representa) a forma de mostrar o objeto pensado e assim poder estabelecer metas para decifrar a realidade a partir de um todo concatenado. Para realizar a seleção da base ou lugar da pesquisa, foi feita a localização dos municípios visitados (mapa 3) para se ter um conhecimento parcial da realidade de cada escola ribeirinha. De posse das leituras, a partir das visões preliminares, selecionou as que foram primeiras comunidades-base da pesquisa, inicialmente.

Este foi um momento imprescindível da pesquisa por permitir a mediação do tempo de percurso, os problemas a serem enfrentados e as possibilidades de contornar cada obstáculo que pudesse surgir, impedindo o andamento de todo trabalho de levantamento de dados. Dessa forma, fica bem demonstrado no mapa que fazer pesquisa em diferentes lugares da Amazônia, exige uma ordem de fatores - indo do esforço e preparação física, emocional - até mesmo a financeira. Quando não se tem clareza desta situação, a pesquisa torna-se muito difícil de realização, mas não é impossível de fazer. Tudo foi muito importante para a tomada de decisão sobre escolha da área que foi pesquisada. 


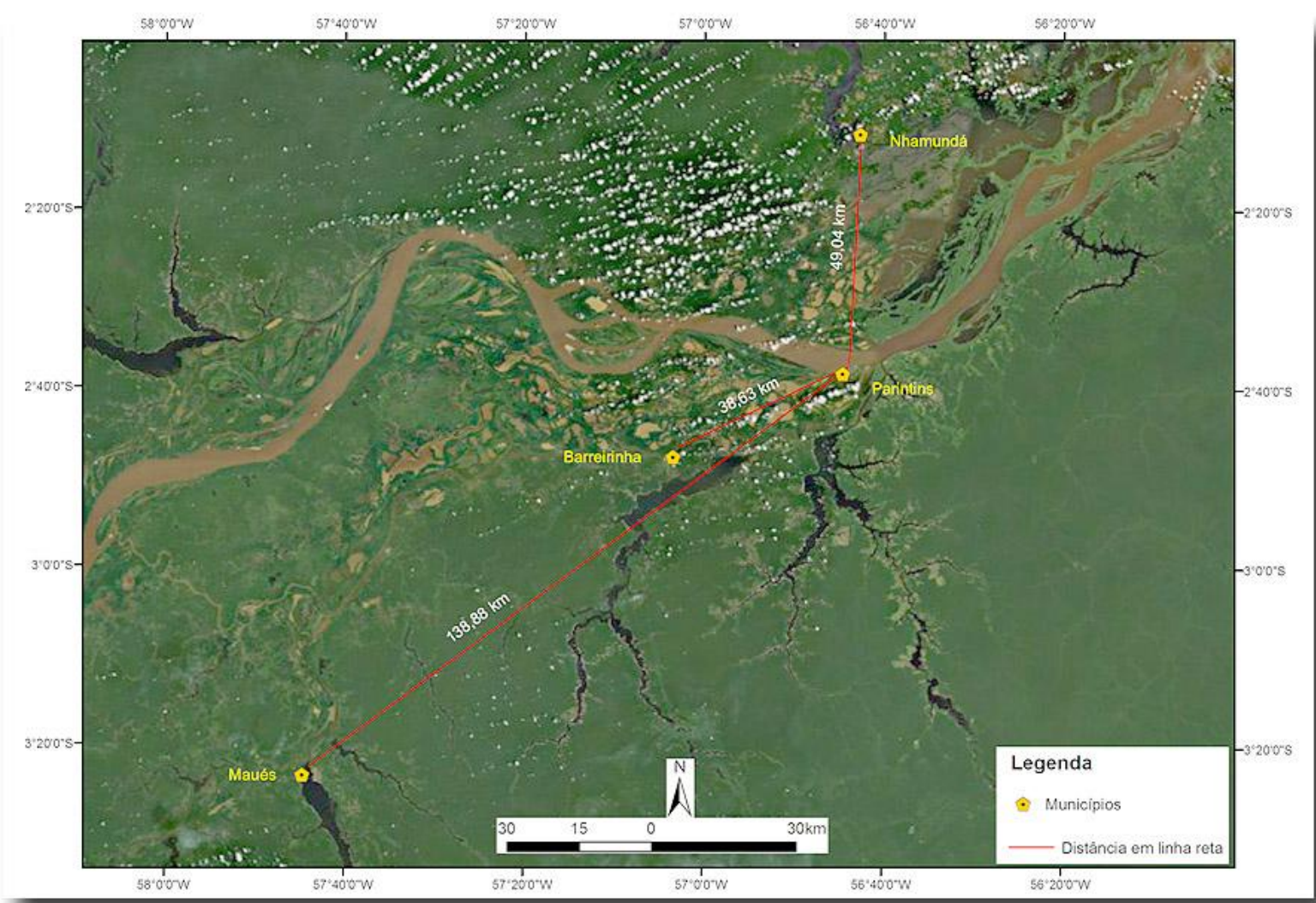

Mapa 3 - Localização dos municípios visitados para seleção da área da pesquisa Organizado por Willer Pinto - Maio/2012

No primeiro momento, foi pensado na realização da pesquisa em dois municípios do Baixo Amazonas ${ }^{2}$, Parintins e Maués, sendo duas escolas de cada município (uma próxima a cidade e a outra distante, uma de terra firme e outra de várzea). Após novas visitas, decidiu-se acrescentar mais uma escola no município de Nhamundá, tirando uma escola do município de Parintins, a de terra firme. Posteriormente foi considerada mais uma escola do município de Barreirinha, para melhor triangular o estudo, na possibilidade de montar um quadro comparativo das múltiplas realidades da Geografia nas Escolas das Comunidades Ribeirinhas do Baixo Amazonas e, consequentemente, do ensino (mapa 3). Isto porque a proposta de pesquisa e da tese estava voltada para o ensino e currículo de Geografia. Porém, em todo processo de construção, foi ocorrendo mudanças importantes para poder concretizar o objeto pesquisado.

\footnotetext{
${ }^{2}$ Baixo Amazonas está se referindo ao Estado, na parte correspondente ao município de Itacoatiara até ao município de Parintins, limite fronteiriço do Amazonas com o Pará. É importante informar que o Amazonas assim divide o rio: Alto Solimões, Médio Amazonas e Baixo Amazonas. Se fosse considerar a divisão do rio Amazonas, Parintins estaria no Médio Amazonas e não no Baixo.
} 
Foram mantidos contatos com as Secretarias de Educação e com os gestores das escolas nas respectivas comunidades. Assim ficou estabelecido um calendário de estudo e de pesquisa. Ao se aproximar o período de cumprimento do calendário estabelecido para a pesquisa, o Prefeito do Município de Nhamundá foi cassado pelo Tribunal Regional Eleitoral (TRE) do Amazonas e o novo prefeito mudou todo secretariado e, ao mesmo tempo, todos os gestores das escolas das comunidades rurais. A escola do município de Barreirinha entrou em reforma, sem previsão de conclusão; a segunda escola do município de Maués, pela dificuldade de acesso e pelos deslocamentos constantes dos professores para a cidade, traria dificuldades para a condução da pesquisa.

É importante informar que o deslocamento para os municípios mais próximos leva em média três horas de voadeira (lancha rápida). Para a cidade de Maués, em média, uma noite de barco (17h de viagem, para percorrer $138 \mathrm{~km}$ ou $204 \mathrm{~km}$ ) e ainda é preciso pegar rabeta (pequena embarcação - tipo canoa - que é movida por um pequeno motor acoplado na parte detrás do bote) ou voadeira para chegar até as escolas das comunidades ribeirinhas.

Considerando os diversos fatores e dificuldades, tomou-se à decisão de realizar a pesquisa em dois municípios: Parintins e Maués (mapa 4), sendo uma escola ribeirinha de cada município. Assim poderia ser associada ao processo da docência na Universidade, a própria pesquisa de campo, em que determinados períodos estabelecidos no cronograma de execução teriam deslocamentos para a comunidade.

A decisão em mudar para os dois municípios se deu em decorrência da exiguidade do prazo, por ser um tempo diferente, mas sem perder o grau de exigência. Com isso, foi alterado o foco da pesquisa para A Geografia nas Escolas das Comunidades Ribeirinhas do Baixo Amazonas: entre o currículo, o cotidiano e os saberes tradicionais. Tudo faz parte do currículo em construção na Amazônia, não como algo pronto e estático, mas como processo dinâmico. 


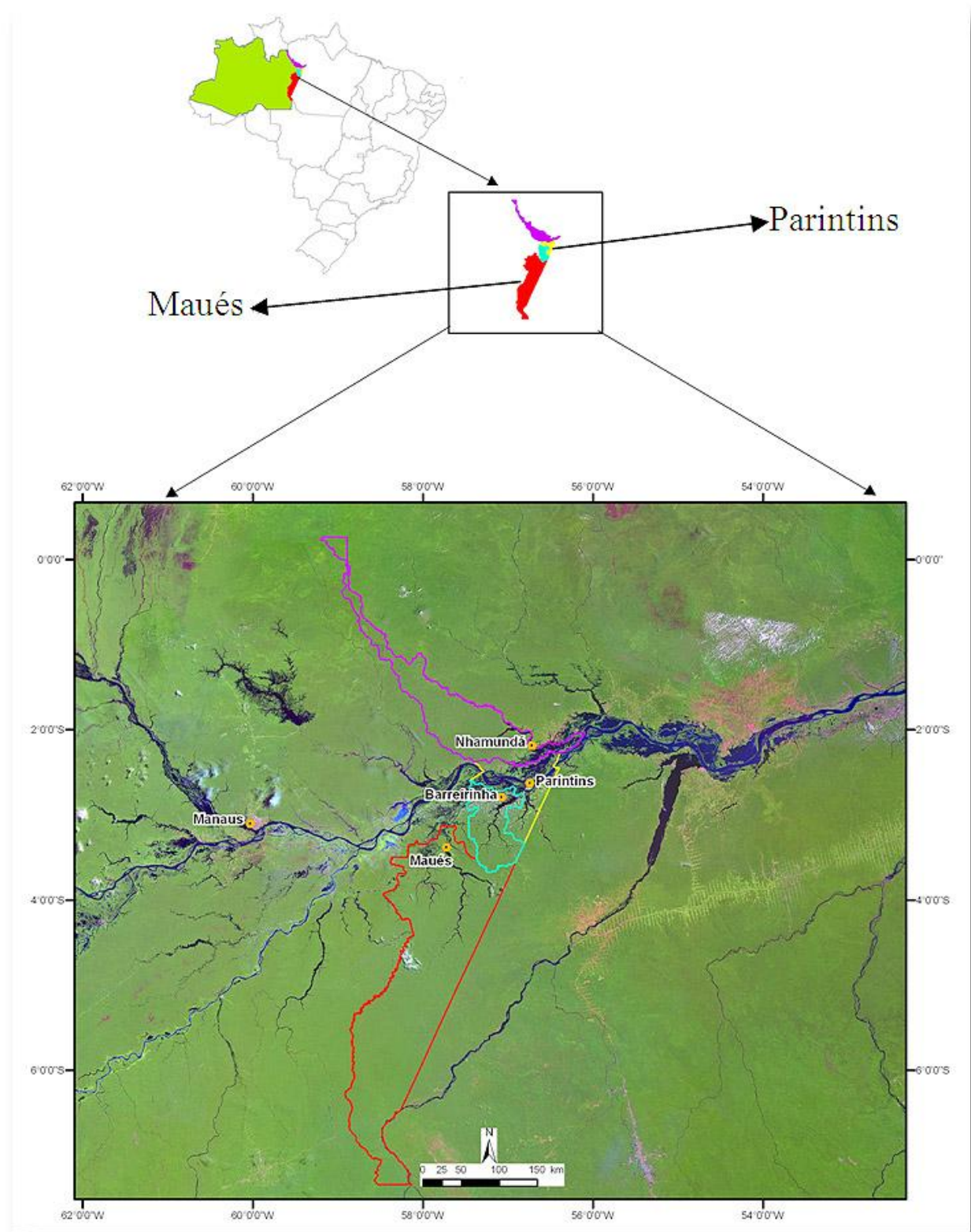

Mapa 4 - Localização dos municípios de Parintins e Maués

Organizado por Willer Pinto - Setembro/2010

Os primeiros levantamentos de dados na cidade de Maués foram planejados a partir das aulas ministradas na Universidade. Enquanto se pesquisava Maués, a de Parintins não se efetivava em decorrência da falta de recursos para cobrir os gastos. No mês que se fazia pesquisa na escola ribeirinha de Parintins, a de Maués ficava sem o devido acompanhamento, agravado também pela distância. 
Quando do processo de qualificação e após questionamento sobre a distância entre Parintins e Maués, foi necessário tomar a decisão de focar a pesquisa somente no município de Parintins e com isto reduzindo a área de pesquisa, conduzindo a alteração ao tema e consequentemente o título da tese, passando a ser: A Geografia nas escolas das comunidades ribeirinhas de Parintins: entre o currículo, o cotidiano e os saberes tradicionais. Para o estudo tomar um corpo consistente, foram feitas visitas em várias comunidades rurais de Parintins para explorar a realidade local. Ao perceber que o processo condutor de ensino era em bases iguais nas escolas, optou-se em manter a pesquisa na Comunidade de Menino Deus - Itaboraí do Meio (várzea e distante da cidade) e na Escola da Comunidade de Vila Amazônia (terra firme e próxima da cidade).

Após a definição da área da pesquisa, partiu-se em busca da verificação de como o objeto pesquisado deveria ser apresentado em outras comunidades e em outros municípios do Estado do Amazonas.

O primeiro município verificado foi Tabatinga, onde foram realizadas várias atividades de acompanhamento e orientação de Trabalhos de Conclusão de Curso - TCC, do Centro de Estudos Superiores de Tabatinga, em que o pesquisador se encontrava como professor do referido Centro, durante três anos (2005 a 2008). Nas escolas das comunidades ribeirinhas, verificou-se o trabalho com classe multisseriada e também por blocos de disciplina.

O segundo município foi de Envira (janeiro de 2010), onde foi possível passar uma semana dialogando com os professores das escolas ribeirinhas que, em depoimento, expuseram a situação do processo de ensino. Notou-se que não havia diferença do de Parintins nem mesmo do de Tabatinga. Algumas mudanças, neste meio tempo, já podem ter ocorrido mesmo porque os professores estão tendo oportunidade de fazer graduação pela Universidade Federal do Amazonas e isto se traduz em no potencial de mudanças e vontades de mudar.

Em visita de campo ao Estado do Pará, aproveitou-se para conhecer a realidade da comunidade e das escolas ribeirinhas do município de Belém. Essas escolas também trabalham com o sistema de classe multisseriada, definida em ciclos, com as mesmas características das escolas selecionadas para a realização da pesquisa.

É importante salientar que todas as escolas de várzea do Amazonas vivem adaptadas à sazonalidade e à dinâmica dos rios de água "branca"; e no Pará, as escolas de várzea de Belém, adequam-se à dinâmica diária da maré do rio Guamá. 
Assim sendo, pode-se dizer que a totalidade se encontra na parte ou na particularidade, como ensina Rafael Straforini (2004, p. 24) “[...]. O lugar é, para nós, a possibilidade da empiricização do mundo, ou seja, é no lugar que o mundo - a totalidade - se faz sentir.”. Então, a caminhada para ver como o objeto pesquisado se apresentava em outro lugar, confirma que a totalidade está na particularidade selecionada, mesmo porque esta particularidade contém a totalidade e por isso o estudo possui relevância científica, social e cultural, confirmando a pesquisa no município de Parintins, nas duas comunidades já citadas.

\subsection{Procedimentos Metodológicos}

A caminhada aquática de investigação se deu entre um banzeiro e outro (onda grande) do rio Amazonas, entre uma enchente e uma vazante ou estiagem - com um único propósito de construir, concretizar e decifrar o objeto pensado, através da pesquisa por encontrar respostas ao problema construído e aos inúmeros questionamentos que teimam em aparecer sobre a geografia nas escolas das comunidades ribeirinhas amazônicas, especificamente as de Parintins. Então, ao partir para a pesquisa, foram adotados procedimentos metodológicos importantes para ir ao encontro do objeto da pesquisa e assim passar a construir, construindose no processo dinâmico da pesquisa e da tese.

Esta construção está embasada nas inúmeras viagens pelo rio Amazonas até as comunidades, no deslocando das sete horas da manhã até o retornando no final da tarde. Passava-se o dia todo na comunidade. No período da manhã eram realizados diálogos com os comunitários e, no período da tarde, uma conversa com os estudantes e professores, tendo a liberdade do acesso à sala de aula. Eram realizadas em média três ou quatro viagens por mês, durante os três anos.

Em todas as viagens era traçado um roteiro, mas nem tudo era possível ser concretizado em decorrência das atividades dos moradores, principalmente quando saiam para pescar; e da suspensão da aula por causa da falta de combustível para os barcos que fazem o transporte escolar. Estes obstáculos foram sendo transpostos no decorrer da pesquisa para que se chegasse aos resultados aspirados na pesquisa.

Os procedimentos metodológicos foram os caminhos trilhados para decifrar o objeto da pesquisa e ir ao encontro dos resultados. Permitiu a reconstrução do objeto pensado durante e depois da pesquisa de campo - que foi materializado a partir da base teórica e conceitual. Estes procedimentos foram processos de transformação do conhecimento empírico 
em conhecimento científico porque permitiu a ressignificação do que foi construído e materializado.

A abordagem metodológica adotada foi a multirreferencial, com destaque para a fenomenologia, por desprender um esforço interpretativo a partir da percepção, que contribuiu para identificar a natureza e a relação do lugar com os sujeitos construtores de sua própria história, como para encontrar as categorias de estudo que permitiram corretamente compreender a realidade para analisar a Geografia nas Escolas das Comunidades Ribeirinhas.

Este ir e vir incessantemente foi respaldado em Merleau-Ponty (2006, p.3) porque se acredita, como ele, que "[...]. Tudo aquilo que sei do mundo, mesmo por ciência, eu sei a partir de uma visão minha ou de uma experiência do mundo sem o qual os símbolos da ciência não poderiam dizer nada. [...]”'. Logo, a experiência poderá ser suporte necessário para poder perceber a totalidade da geografia nas escolas das comunidades ribeirinhas, a partir das particularidades existentes, como a cultura, saberes tradicionais, currículo de geografia e lugar, eixos primordiais e atrativos das representações socioculturais ribeirinhas amazônicas. É importante salientar, que os saberes tradicionais são experiências do mundo. E no mundo amazônico tem que haver o rompimento do pensamento construído sobre a Amazônia, externamente.

Nesta linha da fenomenologia também se utilizou o suporte teórico de Yi - Fu Tuan, a partir de suas obras: Paisagem do Medo (2005), Espaço e lugar: a perspectiva da experiência (1983) e Topofilia: um estudo da percepção, atitudes e valores do meio ambiente (1980), para melhor compreender a relação dos sujeitos na comunidade e suas múltiplas relações e representações de vida. Sujeitos que constroem sua história de lugar a partir do seu modo de vida, representando - para quem olha de fora - como comum ou simples, porém - para quem adentra neste universo - percebendo o quanto há a ser aprendido e compreendido.

Para aguçar o olhar na pesquisa e na decifração do objeto, utilizou-se os ensinamentos de Humberto Maturana, que procura explicar a fenomenologia humana a partir de visão sistêmica, ou seja, o corpo humano é um sistema a ser entendido. Ao projetar para a realidade social, o sistema está todo concatenado, não em um grau de dependência - quase isso - mas em grau de interação e comunicação dinâmica, no sentido do permanente funcionamento porque, se uma parte do sistema não funcionar, o todo será comprometido. Isto pode ocorrer na geografia ensinada na escola ribeirinha - que funciona bem concatenado na comunidade, mas podendo não estar interligado nos ensinamentos de geografia na sala de aula. É na linha 
sistêmica que foi conduzida a pesquisa, porque a geografia nas comunidades ribeirinhas é um sistema que se autorregula, sistema que se altera por forças externas, que se adapta por forças internas, mas que produz e se altera a partir de sua própria realidade. Há de se considerar que a realidade social sempre será uma unidade composta de muitos matizes (MATURANA, 1997).

A fim de conhecer e analisar o problema deste trabalho de pesquisa, seguindo a orientação do método, foi utilizada a metodologia de pesquisa qualitativa, visto que, de acordo com Serrano (1994, p.46)

É um processo ativo, sistemático e rigoroso de indagação dirigida, no qual se tomam decisões sobre o que está sendo pesquisado, quando se vai a campo na busca de coletar dados e respectiva análise de um objeto de estudo. Além disso, incorpora informações ditas pelos participantes, suas experiências, atitudes, crenças, pensamentos e reflexões, tal e como são expressos por eles.

É neste entrelace sistemático da pesquisa e da busca de informações que houve a entrega do pesquisador no campo com o objeto pensado e materializado, ou seja, na pesquisa qualitativa. O pesquisador, para ir a campo, tem que possuir base teórica para alicerçar conscientemente todo processo do exercício mental na compreensão do que está sendo vivido e percebido, refletindo um conhecimento significativo das teorias estudadas tanto da geografia como de outras ciências sociais e da teoria pessoal advinda da leitura empírica (GÓMEZ, 1996). Como produto de uma interação entre os conhecimentos já construídos e alicerçadores do olhar do pesquisador, surgiram às perguntas que ajudaram na orientação da pesquisa:

- A dissociação entre o currículo escolar da escola ribeirinha, os conhecimentos tradicionais e a realidade cotidiana dos estudantes levariam a quase não compreensão do lugar?

- Esta dissociação não permite ao estudante fazer a ligação do conhecimento aprendido de geografia na sala de aula com suas práticas diárias e ao mesmo tempo não consegue ler e reler o seu lugar de vida?

- Por que os estudantes ribeirinhos, em sua maioria, encontram dificuldade de associar os conteúdos estudados de geografia em suas atividades diárias socioculturais: pescarias, plantações, ir e vir do lago?

Estes questionamentos impulsionaram a reflexão sobre o que se ensina e como se ensina a geografia, qual o grau de importância dos conteúdos ensinados para os estudantes das escolas ribeirinhas. Isto porque os estudantes vivem suas realidades com interferências de 
ações e relações externas e se torna importante conhecer para tentar estabelecer percursos de associação dos conteúdos ao fazer diário para que possam ler a realidade local, nacional ou global. Os conteúdos tem importância significativa para a construção da história de vida e compreensão do lugar, porque os estudantes ribeirinhos têm que ressignificar o que está sendo estudado, e isto instigou a pensar nos métodos para estudar as pessoas.

Os métodos utilizados para estudar as pessoas, necessariamente, influenciam sobre o modo que as vemos. É importante não se ater às aparências e sim perceber a essência das relações sociais, porque há sentimento expressado em cada momento vivido. Pretende-se não perder de vista o aspecto humano da vida social, ou seja, viver toda relação coletiva de construções culturais.

Ademais, a metodologia do tipo qualitativa apresenta, como característica peculiar, a diversidade metodológica, de tal maneira que permite extrair informações da coisa com a finalidade de serem contrastadas a partir do prisma do método (AMORIM, 2004). Possibilita, além disso, a realização de provas cruzadas dos dados obtidos, coleta de informação por meio de fontes diversas de modo que a circularidade e a complementaridade metodológica permitam estabelecer processos de exploração em espiral. Recurso que se adotou para a interpretação e análise dos resultados da pesquisa de campo.

A observação livre e participante foi fundamental para perceber todas as relações socioculturais dos sujeitos da pesquisa (pais, professores e alunos) de cada comunidade e de cada escola, por permitir a vivência em determinados momentos de trabalhos no roçado, na pesca, nos banhos no rio Amazonas, na mesa do almoço, na escola ou nas rodas de conversa em cada momento durante a estada nas comunidades pesquisadas. Neste ponto, o pesquisador foi parte integrante das relações comunitárias de convivência diária e dos diálogos que se formavam em cada momento vivido. Foi neste momento de diálogos e de participações nas diversas atividades que o pesquisador adentrou no universo dos comunitários de várzea ou de terra firme, percebendo o mundo de cada estudante ribeirinho.

De acordo com Triviños (1987) “observar, naturalmente, não é simplesmente olhar. Observar é destacar de um conjunto (objetos, pessoas, animais etc.) algo especificamente, prestando, por exemplo, atenção em suas características (cor, tamanho, expressões). Observar um "fenômeno social" significa, em primeiro lugar, que determinado evento social, simples ou complexo, tenha sido abstratamente estudado em seus atos, atividades, significados, relações interpessoais, sociais e culturais. Individualizam-se, essencialmente, para descobrir seus aspectos aparentes e mais profundos, até captar, se for possível, sua essência numa 
perspectiva específica e ampla, ao mesmo tempo, de contradições, de dinamismos, de relações estabelecidas em suas convivências diárias.

Como primeira técnica aplicada, utilizou-se a observação livre para perceber situação de vivência escolar, social e cultural na escola e na comunidade. Postado em ponto estratégico na sala de aula, procurando ficar despercebido - até porque todos já estavam familiarizados com a presença do pesquisador - foi notada a forma de estudo, de ensino do professor e de aprendizagem do estudante, dentro e fora da sala de aula. Na escola de várzea, os alunos ficam em meia circunferência e a professora trabalhando no quadro, lendo o texto do livro didático onde os alunos acompanham. $\mathrm{Na}$ escola de terra firme, os alunos sentam em fila indiana enquanto o professor permanece na frente explicando o conteúdo ou lendo o texto do livro didático.

Através da técnica de observação, foram mantidos dois aspectos de natureza metodológica que são muito importantes. Um deles relacionado com a amostragem de tempo, e o outro, com as denominadas anotações de campo que foram fundamentais para a caracterização desta pesquisa. Ademais, através da observação livre, notou-se a relevância dos sujeitos sociais protagonistas da pesquisa. Observando livremente sem interferência em nada, em nenhum momento, pois o intuito é capturar o comportamento em e além da sala de aula (como, por exemplo, a condução do gado para o curral, a ida à beira do rio para pegar água na lata, o momento do banho com o mergulho no rio Amazonas).

Além da observação livre, em alguns momentos, procedeu-se através da observação participante para entender as relações sociais, culturais, ambientais no convívio cotidiano do estudante de várzea e terra firme. Para tanto, foi necessário estar presente em seu cotidiano escolar e em seus afazeres depois da escola. Na escola foi possível fazer aplicação de atividades com perguntas e respostas. Para cada resposta, os alunos fizeram representações gráficas - verdadeiras expressões cartográficas - que permitiram analisar a relação do conteúdo da geografia estudada na escola com a realidade vivenciada pelos sujeitos da pesquisa. Com relação a seus afazeres, foi necessário acompanhar algumas atividades em casa, na pesca ou no roçado para observar o processo de construção do sentimento de identidade a partir do lugar em que vivem, de como aprendem com seus pais, da forma como entendem a geografia existente na comunidade - mesmo que não saibam que tudo em sua volta são elementos geográficos. Houve momentos de almoçar com a família ou do tomar um cafezinho, sem deixar de observar os afazeres do estudante em seu convívio doméstico, atento às conversas para perceber os ensinamentos repassados. 
Outra técnica importante foi à entrevista, porque, de acordo com Minayo (2004), a técnica em questão é o procedimento mais usual no trabalho de campo. Através dela, o pesquisador busca obter informações contidas na fala dos atores sociais. Ela não significa uma conversa despretensiosa e neutra, uma vez que se insere como meio de coleta dos fatos relatados pelos atores, enquanto sujeitos-objetos da pesquisa que vivenciam uma determinada realidade que está sendo focalizada. Suas formas de realização de natureza individual ou coletiva, deixa sempre bem à vontade o entrevistado para expressar com liberdade. No coletivo, por estarem mais à vontade, falavam e brincavam uns com os outros demonstrando total liberdade. É importante frisar que a entrevista se deu em forma de roda de conversa para que os sujeitos se sentissem livres para expressar seus pensamentos, angústias, tristezas, suas alegrias - ou até mesmo falarem de como ensinam seus filhos durante o trabalho, por exemplo, questionando a realidade do lugar.

Segundo Gómez (1996) a entrevista é uma técnica em que uma pessoa (entrevistador) solicita informações de outra ou de um grupo (entrevistados, informantes), para obter dados sobre um problema determinado. Pressupõe a existência de pelo menos duas pessoas e a possibilidade de interação verbal. O interesse é tomar conhecimento sobre os trabalhos realizados na comunidade e como aprenderam a construir seu material de trabalho, de pesca e a se orientar na mata ou nos lagos. Salienta-se que, na roda de conversa, as perguntas fluíram livremente a partir das diversas falas dos sujeitos, sem, contudo, direcionar as respostas, mas capturar o desejado nas inúmeras falas cruzadas, porque todos queriam falar ao mesmo tempo.

O desenvolvimento da entrevista se apoia na ideia de que o entrevistado ou informante é um ser humano, é uma pessoa que dá sentido e significado à realidade. A partir desta perspectiva, a entrevista é concebida como uma interação social entre pessoas devido ao que se vai originar de uma comunicação de significados: uma pessoa vai tentar explicar sua particular visão sobre um problema e a outra vai buscar compreendê-la ou interpretar aquela explicação.

Para obtenção de êxito no desenvolvimento da entrevista, foi imprescindível considerar aspectos relativos à relação entrevistador-entrevistado, à formulação das perguntas, à coleta e registro das respostas ou à conclusão do contato entrevistador-entrevistado. $\mathrm{O}$ importante é não deixar o entrevistado se sentir pressionado, mas sim, sentir-se bem à vontade para expressar sobre o que está sendo indagado, como por exemplo, sobre a tapiraiauara ${ }^{3}$. Ademais, na análise e interpretação dos resultados, o entrevistador sistematiza, ordena,

\footnotetext{
${ }^{3}$ Animal que possui partes de vários outros animais como partes cavalo, boi, anta. Alguns ribeirinhos dizem já terem se deparado com este animal nas suas pescarias, mas o registro que se tem é apenas a do imaginário.
} 
relaciona e extrai conclusões relativas ao problema estudado. Os dados pouco elaborados coletados em uma fase anterior são transformados em informação valiosa sobre o problema estudado ou aspectos que conduzem à modificação de certas condutas ou atitudes dos sujeitos entrevistados.

Neste trabalho de pesquisa foi utilizada a entrevista em forma de diálogo que, segundo Gómez (1996), incide no desejo do entrevistador obter informação sobre determinado problema e a partir dele estabelecer uma lista de temas, na relação com os que se focaliza a entrevista, ficando a livre discrição do entrevistador, que poderá sondar razões e motivos, ajudar a estabelecer determinado fator, mas sem se sujeitar a uma estrutura focalizada de antemão. Sendo assim, pode-se dizer que quem utiliza tal técnica tem certas ideias mais ou menos fundamentadas, e desejam aprofundá-las até obter explicações convincentes. Pode, inclusive, só desejar conhecer como os outros - os participantes na situação ou contexto analisado - notam o problema.

Optou-se por entrevista em forma de diálogo porque pressupõe como essencial para se obter o conhecimento do ponto de vista dos entrevistados - coletivamente ou dos participantes em uma cultura - também por ser um dos meios para se chegar ao conhecimento, às crenças, aos rituais, à vida de uma sociedade ou cultura, obtendo dados na própria linguagem dos sujeitos, porque se sentem livres para falar e não se sentido intimidados expõe o que sentem com liberdade.

A entrevista permitiu a interação no mundo dos ribeirinhos da comunidade do Itaboraí do Meio e de Vila Amazônia a partir de suas falas e de como narram suas histórias, suas crenças, seus medos e suas coragens, no caso dos pais de alunos, alunos e professores. As histórias contadas pelos pais aos seus filhos, alunos da escola ribeirinha, são experiências construídas cotidianamente e ensinamentos de acontecimentos diários, seja na pescaria (cobra grande que aparece no lago ou outros entes protetores) ou no roçado (curupira, guardião da floresta). São maneiras de ensinarem seus filhos a conhecerem o seu lugar de vida e a viverem as experiências na várzea ou na terra firme.

As falas sobre cada lugar experienciado por um pai de um estudante, foi um elemento importante para entender a dissociação existente entre o currículo de geografia adotado na escola e os saberes tradicionais.

Os sujeitos participantes são pais, professores e estudantes ribeirinhos das escolas das comunidades de várzea e de terra firme. Foi estabelecido um corte temporal e espacial. $\mathrm{O}$ primeiro correspondeu à relação de uma população de sujeitos participantes do período de 
2010 a 2012. O segundo incidiu no universo referente às duas comunidades do município de Parintins, sendo uma de várzea e a outra de terra firme. A primeira distante e a segunda próxima da cidade, especificamente $6^{\circ}$ ao $9^{\circ}$ ano das escolas, sendo uma turma de cada série. O universo dos participantes perfez um total de duzentos estudantes, três professores e pais de estudantes e outros comunitários. Não foi possível quantificar a participação dos pais e outros comunitários porque a pretensão foi sempre deixar livre para entrar e sair da roda de conversa.

Os estudantes da pesquisa foram envolvidos em atividades coletivas para representarem gráfica ou cartograficamente os significados de vida da comunidade. Para que a construção destas representações acontecesse, utilizou-se de atividades de perguntas e respostas, onde os estudantes representariam suas respostas em forma de desenhos. Assim, os desenhos ganharam um valor cartográfico porque deixaram transparecer o lugar vivido, percebido e concebido, ou seja, um lugar cheio de significado e significantes. Cada desenho retratou a comunidade como um todo e os estudantes expressaram suas relações cotidianas, em cada expressão gráfica.

Primeiramente os alunos, em sala de aula, fizeram a representação da comunidade (geral) e em seguida de aspectos mais pontuais, como escola, casa e o entorno. Com a utilização do recurso de "história em quadrinhos", os estudantes mostraram a várzea, a terra firme, rio Amazonas, lagos e ilhas. O segundo momento - voltado mais para os professores, mas com a presença de alguns alunos, serventes, vigias, secretárias e gestoras das escolas - foi ministrado uma aula que abordou o uso dos recursos existentes na comunidade, como cuia (Crescentia sp.), castanha de macaco e o próprio assoalho da escola. Na cuia se fez a representação do globo com projetação das linhas imaginárias para demonstrar as zonas e os movimentos de rotação e translação da terra. Com a castanha de macaco, partida ao meio, mostrou-se a estrutura da terra e usou-se a massa interna da castanha para exemplificar a deriva dos continentes. As frestas do assoalho, servindo como linhas do meridiano, usou-se barbante para as linhas dos paralelos na demonstração das coordenadas geográficas. Este ensaio com o uso dos recursos naturais da própria comunidade, advém do trabalho de um grupo multidisciplinar da UEA - Campus Parintins que se dispôs a socializar ideias para os professores terem formação contínua e assim poderem ressignificar suas aulas. Mas, os membros deste grupo multidisciplinar foram avisados pelo pesquisador de que determinadas atividades seriam usadas em sua tese. As duas produções foram de suma importância, tanto para os estudantes quanto para os professores, que perceberam que há muitos recursos 
didáticos guardados na vivência cotidiana, bem como a sistematização do existente e experimentado na comunidade.

Seguindo a lógica da experimentação, o elemento fundante foi à folha do vegetal onde os estudantes puderam perceber quanta informação há em um elemento tão próximo deles. Por vezes esta informação torna-se distante porque não foi experienciada para aflorar o imaginário e também a criatividade do estudante. A folha de vegetal despertou um novo olhar porque exigiu um pensar diferente do que não estava sendo visto como, no exemplo, a própria dimensão do rio Amazonas e seus inúmeros afluentes.

Os desenhos expuseram as representações dos estudantes das escolas das comunidades ribeirinhas de Parintins, da realidade comunitária, escolar e suas práticas cotidianas. Estes desenhos são de grande representatividade em relação à aprendizagem e permitiram o entendimento do conhecimento que o estudante possui de sua comunidade bem como se há ou não o fortalecimento ou negação de sua identidade cultural.

Com uso da cartografia na sala de aula - como um dos condutores do levantamento de informação para a compreensão da dissociação existente entre o currículo, o cotidiano e os saberes tradicionais - ficou evidenciado como os conteúdos podem ser mais demonstrados, expondo o caminho que os discentes puderam seguir no aprendizado e nas representações gráficas, deixando assim caracterizado cada passo que foi dado na representação do lugar, até mesmo para que possa ser percebido o grau de entendimento sobre sua realidade vivida e também o grau de conhecimento que possuem da geografia de sua comunidade, da possibilidade cartográfica de representar a comunidade, como o registro dos lugares do planeta nos mapas e no globo.

Este procedimento foi importante por dar liberdade ao estudante de projetar ou representar no papel, como registro, do que viu e do que guarda na sua memória, ressignificando os elementos vividos e depois processando como base importante de informações necessárias a serem utilizadas quando necessárias. Isto não quer dizer que o estudante, quando voltar ao lugar por onde um dia passou, irá encontrá-lo do mesmo jeito. Pelo contrário, vai perceber alterações ocorridas até mesmo pela dinâmica natural das mudanças, sejam por crescimento ou desaparecimento de vegetação, da mudança dos cursos de rios, da mudança da paisagem e das comunidades. Além disso, o estudante vai sempre fazer uma leitura diferenciada toda vez que voltar ao lugar de pesca, de caça ou coleta e também do caminho percorrido - e a consciência da importância dos registros em seus desenhos. 
No encaminhamento da análise das informações foi utilizada a proposta hermenêuticodialética apresentada por Minayo (2004), que tem como ponto de partida o interior da fala. E, como chegada, o campo de especificidade histórica e totalizante que produz a fala - cada informação traz em si a essência do objeto pesquisado. Através da fala que se obtém informações claras, precisas e compreensivas sobre o objeto pesquisado, por ser um elemento tradutor e esclarecedor das informações coletadas e as quais serão traduzidas em novos conhecimentos.

Podem-se destacar, ainda de acordo com Minayo (2004), dois pressupostos desse método de análise. $\mathrm{O}$ primeiro diz respeito à ideia de que não há consenso e nem ponto de chegada ao processo de produção do conhecimento. Já o segundo se refere ao fato de que a ciência se constrói numa relação dinâmica entre a razão daquelas que a praticam e a experiência que surge na realidade concreta, para ser transformada ou traduzida em conhecimento científico.

Os passos adotados para aplicar o método de análise foram:

- ordenação das informações, ou seja, neste momento fez-se um mapeamento de todas as informações obtidas no trabalho de campo. Este mapeamento das informações foi necessário para dar uma visão panorâmica do todo pesquisado. Nelas estiveram envolvidas as transcrições de gravações, releitura de material escrito;

- organização dos relatos e interpretação dos desenhos gráficos - verdadeira cartografia ribeirinha e das comunidades;

- classificação das informações a partir dos questionamentos que foram levantados e do que se construiu na fundamentação teórica, elaboração das categorias especificas de análise, como principal o lugar;

- análise final no estabelecer das articulações entre as informações e os referenciais teóricos da pesquisa, respondendo às questões da pesquisa com base no objetivo geral e a respectiva problematização levantada a partir dele.

Dessa maneira, foram promovidas relações entre o concreto e o abstrato, o geral e o particular, a teoria e a prática, relações fundantes da base construtora do conhecimento. 


\section{CAPÍTULO 2 - CONSTRUÇÕES DE SABERES E O LUGAR DE VIDA}

Os ribeirinhos - em sua humilde forma de viver na beira do rio, várzea ou terra firme estão na invisibilidade do conhecimento formal mas conduzem dentro de si toda uma estrutura de saber construído no processo histórico da própria vida sociocultural. Esta invisibilidade se estabelece pela ótica do analfabetismo e pela falta de acesso à escola, onde pudessem exercitar todas as suas potencialidades cognitivas ou ao menos a possibilidade de aprender a escrever o próprio nome. Considerando que isto não é regra geral, são fatos estabelecidos na relação de quem aprendeu na escola e por isso deteria o saber formal. Quem aprendeu na relação coletiva da vida é injustamente visto com não dotado de saber. Isto estabelece um distanciamento entre as duas formas de construção de conhecimento.

Porém, observando e dialogando com alguns ribeirinhos da comunidade do Itaboraí do Meio, no sentido de compreender a estruturação de seu saber, no que representou a cheia de 2009 (a segunda maior já registrada no Amazonas), foi possível obter informações do levantamento do assoalho de algumas casas em mais de um metro acima do ápice da enchente. Alegaram que, quando viesse outra cheia, não seriam afetados. Realmente, na cheia de 2012, a maior já registrada, não foram afetados. A lógica está no tempo de observação entre o período chuvoso, a concentração e retenção de água no período da vazante, não sendo um fator determinante ou limitante, mas uma forma de sempre estar prevenido.

$\mathrm{Na}$ terra firme o saber construído está vinculado à floresta por causa do conhecimento sobre as ervas medicinais, óleos e resinas vegetais que podem curar. Geralmente, a mulher utiliza como anticoncepcional o chá (ou a garrafada) da casca da carapanaúba (Aspidosperma Nitidum), que também serve para inflamações. É importante dizer que as mulheres sabem a dosagem correta, fora do risco de envenenamento. O morador da terra firme entra na floresta e dela sabe voltar, como também conhece os vegetais que podem lhe fornecer sustento e água (cipó d'água, por exemplo) para saciar a sede.

Estes dois pontos de exemplos são representativos de saberes historicamente construídos, a partir do diálogo entre os pais e filhos que procuram repassar verbalmente perdurando de geração a geração. Outro aspecto dessa construção está ligada ao procedimento da experimentação diária e cotidiana, onde a observação vai sendo aprimorada e a mente cada vez mais é exigida em manter os registros de tudo que foi visto e experienciado em cada procedimento prático de sua vida diária na comunidade. É nesta relação de estar atento aos acontecimentos naturais e em constante contato com que é produzido pela floresta, que o 
saber se torna mais estruturado e assim legitimado dentro da comunidade, tendo uma relação direta de socialização coletiva.

\subsection{Saberes do passado vivenciados nos ensinamentos do presente}

Os saberes construídos e repassados de geração a geração estão presentes em cada sujeito construtor de sua própria história dentro da Amazônia, seja no ambiente da várzea ou da terra firme, na beira do rio ou no meio da floresta. Os rios são os meios de acesso e de comunicação, levando ou trazendo novas informações para quem está sempre pronto a aprender e assim poder transformar em novo saber amazônico, além de ser o celeiro fornecedor da base alimentar: o peixe nosso de cada dia. A floresta latifoliada é a fornecedora de recursos extrativistas tanto para alimentação quanto como para a base econômica, e também fonte de aprendizagem e ensinamentos. Esta relação de água e floresta se traduz na alma do amazônida por compreender a dinâmica natural da região e seu intricado sistema de funcionamento.

A Amazônia - vista como região de biodiversidade, multiculturalidade e sempre ostentando sua magnitude - é um grande laboratório de experimentação de aprendizagem e das possibilidades de ensinar a aprender através dos conhecimentos construídos no percurso da história dos habitantes. Neste laboratório, surgiram sujeitos aprendentes que ainda hoje mantêm vivo o conhecimento das gerações passadas e que estão prontos para ensinar às gerações futuras.

Como ribeirinho - que nasceu e cresceu mantendo contato com o povo das comunidades amazônicas das águas (ribeirinhas da várzea) e da terra e floresta (ribeirinho da terra firme), aprendendo com saberes tradicionais - foi possível ver que as questões de educar para conhecer o lugar, nele viver e morar, sempre fizeram presentes nos ensinamentos dos mais velhos. Apesar da escola se fazer presente, não foi percebida a importância dos saberes construídos por gerações passadas existente até os dias atuais.

A escola ribeirinha com seu formato urbano tenta impor a aprendizagem e os conhecimentos (conteúdos) trabalhados em sala de aula sem construir diálogo com o saber local e sem fazer a leitura da geografia existente na comunidade.

A escola da vida, com os ensinamentos provenientes dos pais, possui o grande poder de ensinar a aprender, a conhecer o lugar de vida e a sobreviver dentro da dinâmica natural do rio Amazonas, dos seus afluentes ou da exuberante floresta latifoliada. Ao observar e 
analisar as duas escolas, não foi percebida a conexão dos conhecimentos formais com os informais, não há aplicação do "aprendido em sala de aula" com os fazeres diários dos estudantes, ou seja, não há diálogo do saber escolar com o saber popular ribeirinho. É mais que necessário encontrar alternativas para que a aprendizagem possa fluir livremente na escola, assim como flui na liberdade de aprender nas práticas e atividades cotidianas.

A vivência atrelada à experiência advinda de exercício de ir e vir nas caminhadas pelos roçados, pescarias ou na coleta de frutos e na extração de recursos vegetais proporcionou elementos para firmar o sujeito social da várzea ou da terra firme como um forte, porque os fatores socioambientais não podem deixar de ser considerados como um processo de mudança de comportamento e de adaptação humana a partir das relações comunitárias, sintetizando a vida de quem aprende cotidianamente. Aprender no cotidiano quer dizer aprender em todo processo de formação cultural tendo como parâmetro o lugar de vida.

Este lugar de vida é a própria comunidade por vivenciar relações socioambientais, culturais, econômicas, onde se aprende observando e experimentando tudo que lhe é ensinado e exigido a aprender. Nesse sentido, a aprendizagem está diretamente relacionada a todas as possibilidades de sobrevivência e vivência dentro de tudo que a várzea, em sua sazonalidade dinâmica do rio Amazonas -representa. Da floresta para quem dela retira, não só seu alimento, mas o que pode ser comercializado. Nestes dois ambientes sempre é possível aprender algo novo e assim as lições de vida são construídas.

Dessa forma, a vida é embalada pelas ações e reações de sujeitos que aprendem vivendo a cada momento no roçado, na pescaria, na criação e tornando-se observador do tempo. Com isso gerando saberes para viver os fenômenos naturais e também para poder ensinar as gerações atuais e futuras, registro de saberes ancestrais. Esta aprendizagem diz respeito muito ao saber se orientar tanto durante o dia como a noite nas andanças pelos lagos, pelos rios ou na floresta coletando frutos, fibras, folhas cascas ou mesmo caçando. Como se expressam os ribeirinhos - "saber pegar o rumo, para saber ir e saber voltar".

Quando se fala "pegar o rumo" significa já ter construído todo um referencial do lugar por onde andou. Ter certeza da orientação sem mesmo saber os pontos cardeais, sem ver a luz do sol no meio da floresta mas com segurança caminhar mesmo que tudo pareça igual. $\mathrm{O}$ ribeirinho da água, da terra e da floresta sabe diferenciar os ambientes para poder se guiar e assim não se perder, segurança esta notada nos lagos - onde não se vê a outra margem, como também nas noites sem luar. Seguir com segurança carregando consigo os ensinamentos 
aprendidos e ressignificados a cada percurso feito. Este exercício diário de aprender na convivência ou na experiência dos ribeirinhos está intimamente ligado ao que expressa Amélia Regina Batista Nogueira (1994, p. 61)

[...] para cada homem, ou até cada grupo, existe uma imagem diferente do espaço, e esta imagem não é fantasia, é apreendida a partir do que ele percebe do mundo que o rodeia, a partir de sua experiência de vida, o espaço vivido, que é também concreto, pois é analisado por homens concretos, sujeitos inseridos no tempo e no espaço histórico, sujeitos histórico-espacial. [...].

Sendo assim, as imagens são resultantes do concreto e do vivido e não fruto de pura imaginação porque está em constante leitura dos lugares percorridos. É importante frisar a ligação do ribeirinho com seu lugar de vida é o registro de sua herança cultural, onde cada momento de vida está marcado seja pelas rugas do tempo em seu rosto, seja pelo momento do parto, da queda e enterro do umbigo ou quando cai o primeiro dente de leite, que é jogado para cima do telhado para que o morcego, na crendice popular, possa dar dentes fortes e bons. Este aspecto fica mais bem esclarecido nas palavras de Monteiro (2002, p.38 - aspas do autor).

\footnotetext{
Nossa sabedoria popular registra que nenhum homem se descompromete "do lugar onde enterrou o umbigo". Do umbigo materno, do seu nascer, ele passa ao vinculo com o lugar - a Terra - para onde retornará após a morte. E ao longo da vida, grande parte de seu esforço e energia (vital) é desprendida - na sua solidão - em querer juntar umbigos, como dizia Doralda a Soropita... "nunca te deixar, era se eu pudesse estar guardada em você, de carne, calor e sangue, costurados nós dois juntos...". União, pacto, cumplicidade para a difícil travessia...

Penso que dessa vinculação do Homem à Terra - da configuração do lugar à condição humana - é que emana a "universalidade" que procuramos.
}

Esta vinculação do ser humano com a terra é porque se sente parte integrante e, como tal, projeta toda sua existência, todo seu viver e seu aprender. Assim, a sua ligação com o lugar é fortalecida com tudo que é experienciado em sua jornada diária, ressignificando o seu viver. "Na Geografia Humanista, lugar é o espaço que se torna familiar ao indivíduo, é o espaço do vivido, do experienciado" (CAVALCANTI, 1998, p.89 - grifo da autora).

O lugar é repleto de significados construídos em um processo histórico-espacial integrante de relações sociais, culturais, econômicas, ambientais, físico-naturais, como teias de relações reveladoras da multiplicidade multicultural existente na comunidade, porque segundo Armand Frémont (1980, p.139) 
Todo o lugar tem significado. Combinação de elementos econômicos, ecológicos, sociológicos e demográficos, num espaço reduzido, o lugar visualiza-se através duma forma que se integra na paisagem local e regional. Aquilo que representa deve ser descriptado um pouco como uma linguagem, a linguagem dos homens falando com o espaço como um meio de expressão. Esta análise interna dos lugares e a procura de estruturas comuns conduzem a uma definição de algumas grandes posições de civilização,[...]. Mas revelam também uma enorme riqueza de expressão na multiplicidade das formas, das práticas e das suas significações. [...].

Dessa forma, o lugar é espaço de vida em constante construção e transformação do ser humano, onde se produz para manter a sobrevivência e a existência, e, assim viver socioculturalmente, exercitando plenamente a liberdade ${ }^{4}$, porque tudo está no cerne da percepção quando é experimentado. Segundo Tuan (1983, p.5-6)

\begin{abstract}
Considerando os dotes humanos, de que maneira as pessoas atribuem significados e organizam o espaço e o lugar? Quando se faz esta pergunta, o cientista social é tentado a ver a cultura como um fator explicativo. A cultura é desenvolvida unicamente pelos seres humanos. Ela influencia intensamente o comportamento e os valores humanos. A sensação de espaço e lugar dos esquimós é bem diferente da dos americanos. Esta abordagem é válida, mas não leva em conta o problema dos traços comuns, que transcendem as particularidades culturais e, portanto, refletem a condição humana. Na observação dos "universais", o cientista comportamental provavelmente se volta para o comportamento análogo do primata. Neste trabalho, reconhecemos nossa herança animal, bem como a importância desempenhada pela cultura. A cultura é inevitável, [...].[...]. É antes um prólogo à cultura em sua infinita diversidade; enfoca questões gerais das aptidões humanas, capacidades e necessidades, e como a cultura as acentua ou as distorce. [...].
\end{abstract}

Esta reflexão de Tuan fortalece o pensar sobre o ribeirinho e seu lugar de vida. Sobre a construção de seus saberes tanto na várzea quanto na terra firme e abre questionamentos, como: qual realidade a ser construída? Como perceber a realidade se ela não for experimentada, no sentido do viver e conviver? É neste ensaio do experienciado que se constrói cultura porque há participação de vida coletiva, participação da vida do outro no sentido da compreensão e interação das relações socioculturais dentro e fora da comunidade, onde o estudante ribeirinho experimenta e exercita seu aprender na relação direta do viver e conviver, participando ativamente do fazer e do dialogar em família ou em comunidade.

Os diálogos são ferramentas dos ensinamentos, são os primeiros passos das lições a serem aprendidas pelos estudantes ribeirinhos com os seus pais. A outra forma é acompanhar os pais nos afazeres diários e sempre experimentando para aprender. Neste processo a criança cresce em saberes, porque está contida nos ensinamentos, a questão do saber para sobreviver, do aprender para se defender e assim manter o equilíbrio sociocultural-ambiental porque

\footnotetext{
${ }^{4}$ Meio urbano: liberdade para fazer o que é obrigado; no meio ribeirinho: liberdade para fazer o que é necessário fazer.
} 
também é um guardião do lugar; tem que construir sem destruir, mesmo que seja acusado de destruidor, mas sabe o que pode pegar do meio natural sem afetar o sistema. Sabe que não pode tirar além do permitido, porque vai lhe faltar algum dia. Com isso exercita o saber para manter o equilíbrio natural. Talvez o olhar do externo não deve focar dentro desta ótica porque sempre vai pensar que o ribeirinho da água (várzea) ou da terra e floresta (terra firme) é um destruidor. Mas, quem convive ou mantém contato com o ribeirinho, mesmo que seja de forma rápida, percebe o quanto ele possui de consciência sobre a questão do equilíbrio ambiental na sabedoria que do lago ou da floresta ele depende para sua sobrevivência.

Nessa construção de saberes alicerçados nos ensinamentos do passado, a vida segue seu curso natural e, em contato com o que o urbano produz de novo, ocorrem alterações na sua forma de ver e agir dentro da comunidade, mesmo mantendo todo traço da vida ribeirinha. Muito da herança deixada, aprendida, vai sendo alterada, esquecida ou transformada, porque os alguns dos mais jovens não querem mais aprender, principalmente os que moram nas comunidades próximas da cidade. Os que moram em comunidades mais distantes mantém muito do que lhes foi ensinado dos ensinamentos do passado. Estas mudanças são perceptíveis nas palavras de Callai (2003a, p. 62)

\begin{abstract}
No entanto não é o lugar em si que importa compreender. Mas como as forças que ali existem estabelecem o jogo que vai permitir o resultado da complexidade da vida social. São forças decorrentes da natureza, do econômico, do político, do cultural. Algumas internas, outras externas. Neste jogo, para que não ocorram determinismos há que se ter a consciência dos sujeitos como cidadãos capazes de interferir nas dinâmicas existentes, e como tal compreenderem do que resultam as organizações do espaço. Compreender que as feições que assumem as paisagens são decorrência de uma história da vida das pessoas, dos grupos que ali vivem, situados num tempo e num espaço determinados, inseridos em uma dimensão que os contextualiza.
\end{abstract}

Neste meio de transformação da vida social, como expõe Callai, decorrentes das forças externas - político, econômico, social, ambiental - inseridos nos processos internos da vida comunitária dos lugares, aflora as resistências onde os ensinamentos continuam sendo feitos mesmo quando há incorporação do urbano, porém serão ressignificados mas o externo vai exercendo pressão para a mudança do comportamento social. É importante frisar que não é ser contra o que está sendo produzido pela lógica do capitalismo consumista e gradativamente inserido na comunidade, mas ser a favor da manutenção, valorização e fortalecimento da herança cultural que sempre estiveram presentes na construção e história de vida das pessoas do lugar.

Nesse contexto, abre-se espaço para dialogar dentro do saber tradicionalmente construído, ensinado e vivido, como também fonte de saber esquecido porque foi substituído 
pelo que se apresenta de "novo", ou seja, troca-se a cuia pelo tonel de plástico. No percurso das discussões desta tese, outras heranças serão mostradas para haver entendimento da construção de elementos culturais.

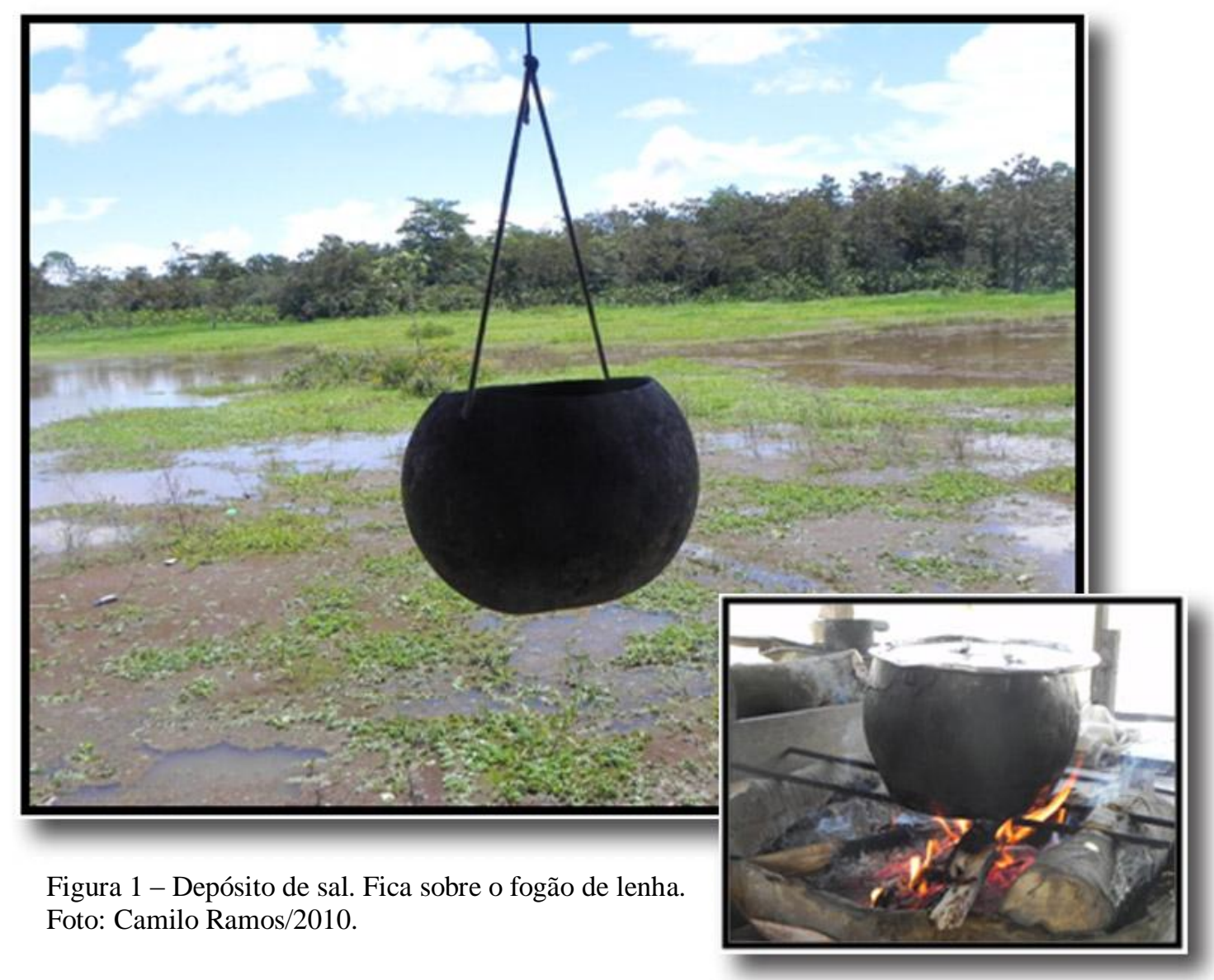

Figura 2- Panela sobre fogão de lenha Foto: Camilo Ramos/2010.

Este elemento comum apresentado na simplicidade da casa do ribeirinho, pode não representar e não ter muito sentido ou importância para quem olha. Mas está cheio de informações e de significados, de representações socioculturais, porque assim foi ensinado e aprendido a usar o que a floresta fornece. Não é o fogão à lenha com a panela, mas a cuiú pendurada sobre o fogão, conhecido como "bocó", ou seja, a utilidade é de depósito de sal". Fica sobre o fogão porque, na hora em que está se preparando o cozido, mete-se a colher e retira a porção necessária do sal sem ter que deslocar da proximidade do fogão. A cuia já teve outras utilidades e foi de grande importância na vida social do ribeirinho quando ia para o

\footnotetext{
${ }^{5}$ Aspecto utilitário/funcional tem supremacia sobre o caráter estético nos artefatos, utensílios e apetrechos do ribeirinho.
} 
trabalho. Servia-se com uma tampa, também feita de cuia, para colocar farinha, carne ou peixe assado para comer na hora do almoço no roçado, sem perda da qualidade do boião (comida) que ficava protegido da chuva. Também a cuia servia para carregar água do rio para colocar no pote (vasilha de barro) e em um jirau de madeira ("pau de balde" - varas sobre esteios fixados no chão e separados por varetas, para segurar os baldes) ficava vários baldes de cuia com água para lavar a louça e para outros afazeres domésticos. Servia como cartucheira, ou seja, uma cuia menor com tampa de cuia servia para guardar pólvora, chumbo, espoleta e o próprio cartucho (munição para caça), quando saía para caçar seu alimento. Outra função era de guardar os acessórios para o fumo (tabaco, papelinho e fósforo). Na canoa, a cuia servia para tirar água de dentro da pequena embarcação. No fazer da farinha, cortada em tiras de $15 \mathrm{~cm}$ a $20 \mathrm{~cm}$, chamada de cuiapéua, servia para mexer a massa da mandioca quando colocada no forno quente para escaldar no processo da farinhada. Quando ficava pronta para colocar no paneiro, usava-se uma cuia grande também como sistema de medida. Hoje em dia não se vê mais o uso da cuia e de suas várias utilidades culturais. O vegetal, a cuieira ${ }^{6}$, também está desaparecendo da comunidade.

\footnotetext{
${ }^{6}$ No meio urbano: cuia ornamentada para tacacá (Tacacá é uma iguaria alimentar preparado com amido de tapioca proveniente da mandioca e misturado com tucupi, caldo amarelo de mandioca, contendo também jambu). Em roda, foi lembrado que a polpa da cuia é um excelente remédio contra a sarna canina. Conhecimento herdado, praticado e ensinado pelos mais velhos nas comunidades ribeirinhas.
} 

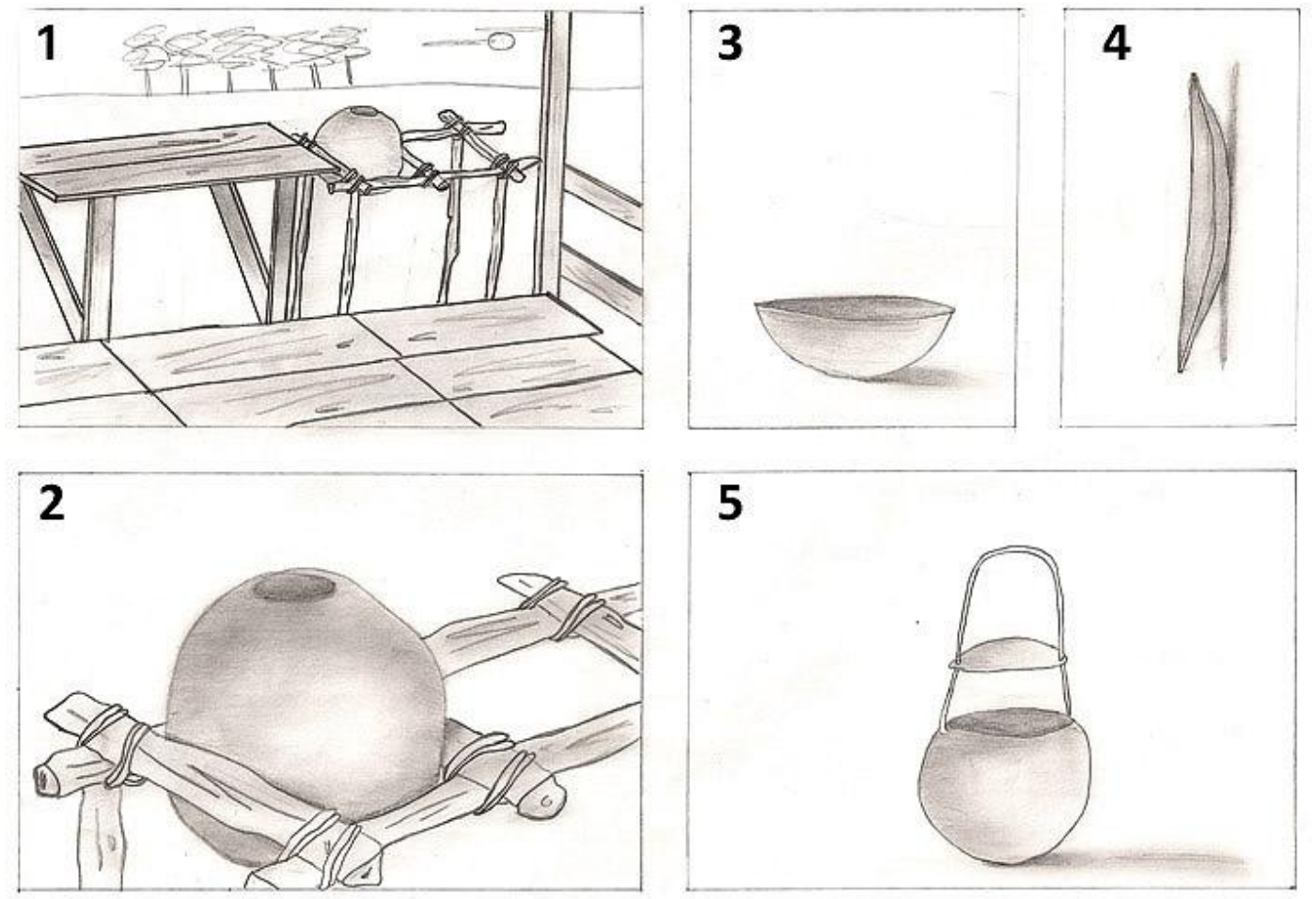

Figura 3 - Utensílios domésticos

Desenho de Claire Maria Jesus Souza - Out/2012

1 - Jirau - tábuas sobre tronco onde se cuida o peixe e lava as louças e ao lado o jirau - pau de balde suporte dos baldes de cuia; 2 - balde de cuia- utilizado para carregar água do rio para os afazeres domésticos; 3 - Cuia cortada ao meio - serve para tirar água da canoa e também para medir a farinha quando estiver torrada e for colocada no paneiro ou no saco de fibra; 4 - cuiapéua - serve para mexer a massa da mandioca no processo da farinhada; 5 - bornal ou bolsa de cuia - espécie de marmita e também as cuias menores serviam como cartucheira.

Assim sendo, a cuia é um elemento cultural que foi ensinado o que seu uso está se perdendo até porque, quando se fala hoje em sustentabilidade, esquece-se de como os conhecimentos tradicionais trabalhavam o uso dos recursos naturais sem destruir, mesmo porque para ter cuia era preciso manter vivo o vegetal ou plantar novas cuieiras para se ter sempre o utensílio. Hoje é perceptível a ausência deste vegetal nas comunidades.

São pequenos e importantes elementos de construção de vida, de conhecimentos existentes. Os mais velhos guardam em suas memórias e tentam repassar aos mais jovens que pouco se preocupam em aprender. Ainda há jovens que aprendem e dividem seus saberes, como afirma Alfredo Wagner Berno de Almeida (2010) que aqui há as alternativas para o que se discute em termos de desenvolvimento, por ser um conjunto de medidas de construções de elementos sócio, histórico e cultural. Há manejo, também processamento e transformação de 
matérias primas em utilidades domésticas, vistas como artesanais, pré-industriais ou simplesmente rudimentares. Porém são eficazes na sua utilização. Se a escola usar estes utensílios como condutores de conhecimento, ou associados aos conteúdos geográficos trabalhados em sala, ganharão corpo e importância e serão marcas na história de vida do lugar, ajudando a Amazônia sair das amarras da herança da dominação. Amazônia passará a ser pensada endogenamente pelos seus nativos, pelos que vivem nela, sendo inspiração do pensar do amazônida, superando a visão colonialista, a visão do de fora.

Dessa forma, a vivência atrelada à experiência advinda de todo um exercício comunitário poderá proporcionar elementos fundantes para afirmar que o fator socioambiental e histórico não pode deixar de ser considerado um processo de mudança de comportamento social, mesmo porque ser educado para a vida é recuperar os ensinamentos pretéritos para serem utilizados e vivenciados no presente dentro das relações comunitárias, que sintetizam os reflexos oriundos das práticas cotidianas e tradicionais, orientadoras da construção de novos saberes a serem utilizados para a construção de estratégias que fortaleçam as práticas socioeducativa, socioambiental, sociocultural e histórico-espacial, no lugar e do lugar.

\subsection{Construções de vida na Amazônia: o ribeirinho}

Diante da perspectiva de discutir os sujeitos construtores e o conceito abarcador de seu nome ribeirinho, far-se-á a partir da perspectiva que este sujeito sempre esteve para falar, já tinha falado e é um falante de suas dinâmicas sociais e das construções de vida a partir de suas representações construídas e compartilhadas na comunidade. Como sujeito dinâmico, conservador e preservador de tudo que aprendeu para ensinar e de tudo que ensina para aprender, com suas experiências e com a observação para sempre "ler" a dinâmica natural dos fenômenos amazônicos.

É nesta relação entre o ser humano e água, o ser humano e terra (solo) e o ser humano e floresta que se configura o ribeirinho em relações socioculturais complexas, produzindo saberes não acadêmicos e nem escolares, que não são fins e sim processos de construções a partir de suas necessidades de vida e também por trazerem dentro de si o sentimento de pertencimento ao lugar e todo um modo acurado de observador, coparticipe.

Dessa forma, o ribeirinho é um forte, é um batalhador, é um resistente por ser um aprendiz das lições ensinadas pelos diálogos em rodas de conversa com os mais velhos ou com os mais experientes e, sobretudo, por aplicar no seu cotidiano, essas vivências (como, por 
exemplo, no fato dele, nas idas e vindas por caminhos diferentes, encontrar o caminho de sua casa mesmo em noite sem luar). Este senso de orientação, as crianças aprendem acompanhando seus pais e o que se ensina na escola torna-se difícil ser posto em prática ${ }^{7}$, mesmo porque nem sempre vai ter nos lagos ou na floresta os pontos de referência que na aula foram falados, assim, não se torna falante o conteúdo estudado, mas é falado e falante o que foi experimentado na prática, pois, segundo Moraes (2008a, p. 110)

É nesta configuração da relação entre homens e águas que nos propusemos a
investigar saberes que envolvem a pesca, sabendo que a construção destes é um
processo que envolve relações complexas, e que não se limitam nem se esgotam
num conhecimento acadêmico ou escolar. Mais que isto, os saberes não-científicos
ligados a populações tradicionais envolvem relações estreitas entre o homem e a
natureza, permeados por relações de ordens pontuais e também míticas. São
conhecimentos transmitidos das gerações mais experientes para as mais jovens,
principalmente pela oralidade e pelas práticas do cotidiano.

Os saberes socializados encontram-se como mediadores da existência no lugar, até mesmo pela sua forma de transmissão e propagação entre os mais velhos e os mais jovens. É no processo do experimentar que os lugares são marcados na mente para serem sempre recuperados quando necessário. Indicação do lugar da pesca, do lugar da coleta de frutas, cascas ou outros produtos naturais, com a certeza do retorno. Segundo Moraes (2008a) os mapas mentais são construídos em verdadeiros esquemas matemáticos, servindo como pontos de referências para encontrar os lugares de pesca. Este conhecimento empírico e os métodos adotados de localização só acontecem por causa da associação de vários elementos naturais pertencentes ao meio de vivência e também por se permitirem pertencer e se tornarem parte integrante. Esta visão de mapa mental corresponde aos ensinamentos de Nogueira (1994) que analisa os mapas mentais como projeções do lugar de vida, como espaço socialmente construído e experienciado. Esses mapas formam as bases fundamentais de orientação e auxiliadoras nas navegações para todo processo de ocupação e colonização do que chamaram "descobertas" do mundo. Então, através dos mapas mentais se fazem as representações dos lugares conhecidos.

Os lugares marcados nas mentes estão registrados como lugares importantes na vida dos ribeirinhos e, como um ser dinâmico, vai em busca de novos desafios para conhecer o desconhecido, sempre tendo em mente as lições ensinadas sobre os perigos existentes no rio ou na mata. Com isto, aguça o imaginário, materializando o invisível e dessa forma

\footnotetext{
${ }^{7}$ Cabe a escola adaptar-se aos saberes do meio, aos seus referenciais, atores e protagonistas. Senão, não vai afetar a comunidade.
} 
aprendendo a lidar com situações diversas e ao mesmo tempo aprendendo a respeitar as suas limitações. Estes aspectos do imaginário se apoiam nas palavras de Moraes (IBID, 2008a, p.119-120).

\begin{abstract}
O mundo material e as construções imaginárias, ao mesmo tempo em que impulsionam a criação e recriação de saberes, são também resultado da cultura por nós produzida. São inumeráveis práticas e os saberes que evidenciam as relações entre cultura e natureza. Os seres do céu, da terra, do ar e da água, e as ligações entre eles, têm-se constituído em ferramentas do pensamento que servem de base e indagação em diversas áreas do conhecimento.

O mundo da pesca também é o mundo dos mitos. Os seres das águas, das florestas, dos vales, seres "encantados", são elementos que dão significados e que fazem da pesca uma confluência entre o real e o imaginário. Os seres fantásticos e as encantarias podem interferir na ação dos pescadores sobre a natureza na medida em que se traduzem em respeito e temor em relação às entidades protetoras das florestas e das águas. (grifo do autor).
\end{abstract}

Então, recheados de construções imaginárias e traduzindo em saberes tudo que viram ou o que sentiram durante a pescaria ou nas idas a floresta caçar, sentam-se e começam a relatar o que lhes aconteceu. Para quem vê as rodas de conversa como se fosse algo despretensioso, somente com a vontade de contar, não consegue perceber a riqueza de conhecimento e detalhes de informações. Este momento é o de socializar conhecimentos, porque não se expressam apenas pela oralidade mais com o corpo e o sentimento de existir e resistir. Falam de vida e de como conseguiram vencer o seu próprio temor, porque poderiam ser levados ou serem encantados pelas entidades da água ou da floresta. Se isso acontecesse, seria fatal à sua vida.

No momento em que estão contando o ocorrido, desperta na mente dos jovens a imaginação sobre tudo, como se fosse uma projeção de onde se encontra o lugar do ocorrido e assim consegue "ver" o lugar e a entidade. As crianças não falam, mas estão atentas a todos os detalhes; os jovens perguntam e questionam. Dessa forma, os saberes são socializados e ao mesmo tempo ressignificados pelos mais jovens. Nesta linha de raciocínio, apodera-se das palavras de Alves (2008, p. 24-25), quando se expressa sobre esta relação do contar história e do viver a história, imaginando, criando e recriando, não fantasias, mas saberes.

Contar histórias é jogar com a memória, com a criatividade, é ir à busca do prazer e da imaginação. É viver dialeticamente entre o ir e vir do oral e do escrito no jogo da tradição do reinventar. Desse modo, contar histórias é jogar com voz e gestos. $\mathrm{Na}$ trama tecida pela arte de contar há, então, o jogo de ouvir e contar, o jogo do envolvimento, da sensibilidade, do prazer, do imaginário, do jogar com a memória, pois esta cria e recria formas de contar e de ampliar o repertório oral. 
Dentro desta trama, os jovens e as crianças, atentas a tudo que é relatado, viajam em seus imaginários, criando e recriando as imagens a partir do que é relatado, trabalhando com a mente e fazendo o exercício da aprendizagem. Quando se volta os olhos para estes aprendizes na sala de aula, estão calados, olhando, procurando entender o conteúdo trabalhado, mas não conseguem exercitar a mente como ocorre nas rodas de conversa mesmo que não tenha uma participação direta, mas aprendem com as falas dos mais velhos e não conseguem aprender e sim decorar os conhecimentos formais na aula.

Outro aspecto importante é a não associação destas histórias aos conteúdos trabalhados na sala de aula que são oriundos de uma proposta curricular ou lista de conteúdos que o professor deve seguir. Apesar de ser dito que os professores tem liberdade de criar, há a cobrança quando estes professores não trabalham diretamente os conteúdos contidos do que é repassado pela Secretaria de Educação. Alves (2008) questiona a não inclusão das lendas indígenas na literatura oral brasileira, apesar de ser um elemento muito importante para o processo de aprendizagem. Ainda há focos de resistência dentro da Amazônia, quando muitas lendas indígenas ainda são disseminadas pelos ribeirinhos, principalmente nas rodas de conversa "na boca da noite" (primeiras horas da noite - entre 18h e 20h).

Os ribeirinhos possuem a capacidade de contar as histórias de vivência e do imaginário ligados ao rio: boto virando homem, cobra grande com olhos de fogo, a cidade dos encantados dentro do rio. Na floresta, as entidades protetoras manifestam-se como o curupira que leva o homem se perder na mata, tendo que tecer a palha, acender um cigarro para o curupira. Enquanto o curupira fuma e desamarra a palha, o homem consegue sair da floresta e assim fica livre da magia do curupira. Estas histórias fazem parte dos mistérios amazônicos apresentados ao ribeirinho da água ou ao ribeirinho da terra e floresta como forças protetoras dos recursos naturais. Alves (2008, p. 40) discute estes aspectos como um sistema construído e que está bem concatenado, sendo base de fortalecimento da identidade do amazônida.

A narrativa na Amazônia é tecida e fiada por outro elemento recorrente na trama - $o$ rio, o que ora aparece no início da trama, ora aparece como cenário desta. Ele é o lugar onde se presenciam as metamorfoses do Homem-Boto e simboliza na rede desta trama o fluir de suas águas, o poder do rio de encantar, já que reflete o "visível e o invisível" para o povo amazônico. Há também o simbolismo do "fluir das formas", o da fertilidade, da morte e da renovação. O rio é, de um lado, a corrente da vida; e, de outro, a corrente da morte.

Para o homem amazônico, o rio é o espelho que reflete o imaginário impregnando pela viscosidade de transfigurar o real. É por ele que se cria e recria a vida cultural dos caboclos ribeirinhos, pois é pelo rio que se instaura uma zona indistinta entre o real e o surreal. O rio é a rua para os ribeirinhos. É também o espelho que reflete e 
refrata a sua identidade. Para o caboclo amazônida, o contato com as águas do rio é quase visceral, uma vez que depende dele para quase tudo. O caboclo usufrui desses bens e sente-se à vontade para transfigurá-lo de acordo com seus devaneios. O rio é o lugar dos encantados, dos sujeitos misteriosos, detentores de poderes que "mundiam" as pessoas com seus poderes, mas que também seduzem, provocam prazer.

Como é possível dizer que o estudante ribeirinho não possui saber? Não possui conhecimento? Por que a escola chega a negar o conhecimento construído nos diálogos com seus pais e com os mais velhos?

Estes questionamentos podem ser respondidos pela ótica do ensino dominador herdado de um processo colonizador, fazendo-se presente ainda na forma como é ensinado e também a forma como os professores aprenderam. Torna-se um jogo de empurra e de não assumir a responsabilidade das falhas e muito menos propor mudanças. Isto não quer dizer ou desvalorizar o conhecimento construído, mas mostrar a viabilidade de associar os saberes formais aos saberes não formais dentro do processo ensino e aprendizagem nas escolas. Senão, estará sempre vendo o estudante desprovido de saberes e ao mesmo tempo conduzindo ao ponto inferior ao do estudante da cidade.

Dessa forma, há de verificar a finalidade do que se aprende na cidade e nas comunidades ribeirinhas amazônicas, uma vez que os saberes têm finalidades percebidas e invisíveis. É importante considerar os valores míticos dos ribeirinhos da água e dos da terra e floresta, por estarem repletos de conceitos e valores culturais, enriquecedores da vida cotidiana.

O sentido da discussão não é para deixar o ribeirinho isolado do que está sendo construído e transformado nos centros urbanos, muito menos distante das informações das ocorrências mundiais. Ao contrário, é proporcionar mecanismos para que possa estar sempre vendo, lendo e discutindo as realidades próximas e as distantes, sem perder os valores construídos no lugar, até porque, segundo Fraxe (2009) não se pode deixar de considerar o não isolamento no tempo e no espaço dos povos amazônicos, por estarem em constante contato e mantendo relações de escambo entre as comunidades, compra e venda com a cidade, contatando as inovações, assimilando novas informações e rejeitando outras, mas as assimiladas sendo ressignificadas, readaptadas, tendo um novo sentido de vida, pois, estão dentro da dinâmica do processo de diferenciação e transformação do e no lugar, na região, no país e no mundo.

Fica evidente, com estes aspectos estruturantes do ribeirinho, como são construídos em sua prática social e histórica cotidiana, imbricados nas suas relações socioculturais, 
dinamizadoras de características peculiares do lugar e no lugar, produzindo na dimensão individual de cada sujeito entendedor de si na relação com o outro, montando o tecido da existência e dos saberes coletivamente construídos, vividos e exercitados individualmente ou em grupo.

É importante ressaltar que os ribeirinhos são verdadeiros artesões de si mesmos e de tudo que precisam nas suas práticas cotidianas, tais como: fazer a tarrafa e a malhadeira (e, após a pescaria, consertá-las), fazer sua flecha e seu arco, preparar sua zagaia (preparar e ter sempre pronto seus arreios de pesca). Não há um mercado fornecedor desses apetrechos. Os ribeirinhos nunca se encontram desprevenidos tanto para a pesca como para o trabalho no seu roçado.
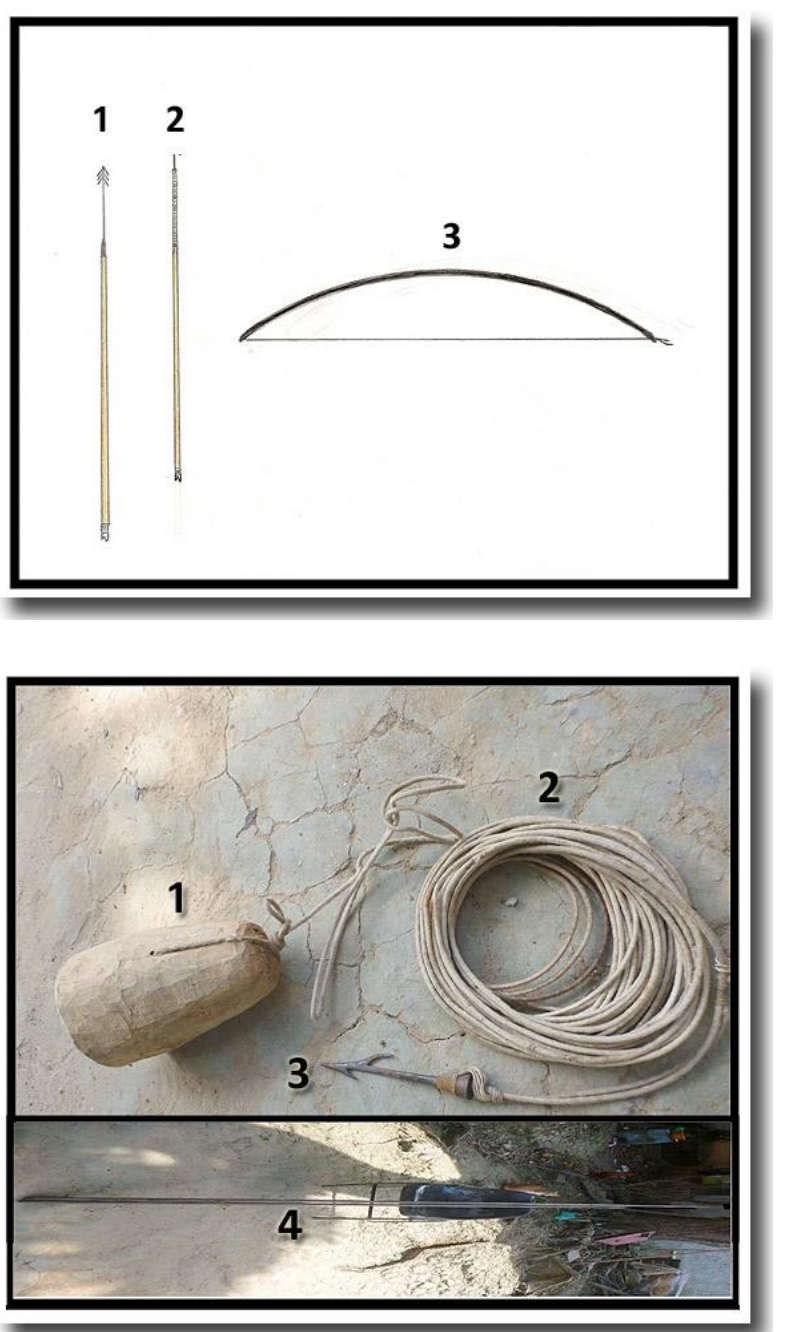

Figura 4 - Utensílios de Pesca.

Desenho de Claire Maria Jesus Souza out/2012.

$\mathbf{1}$ - Flecha com ponta de ferro.

2 - Sararaca - metade cana flecha; pedaço de âmago de madeira de lei e pequeno arpão envolvido com uma carda de dois metros.

3- Arco de madeira apropriada para a construção deste instrumento de pesca; com uma corda resistente.

Figura 5 - Utensílios de Pesca do Pirarucu.

Foto: Camilo Ramos - out/2012.

1 - Boia de Molongó

2- Arpoeira

3 - Arpão

4 - Haste - madeira de lei.

Este conjunto de material compõe um único arreio de pesca artesanal; pesca do pirarucu. 


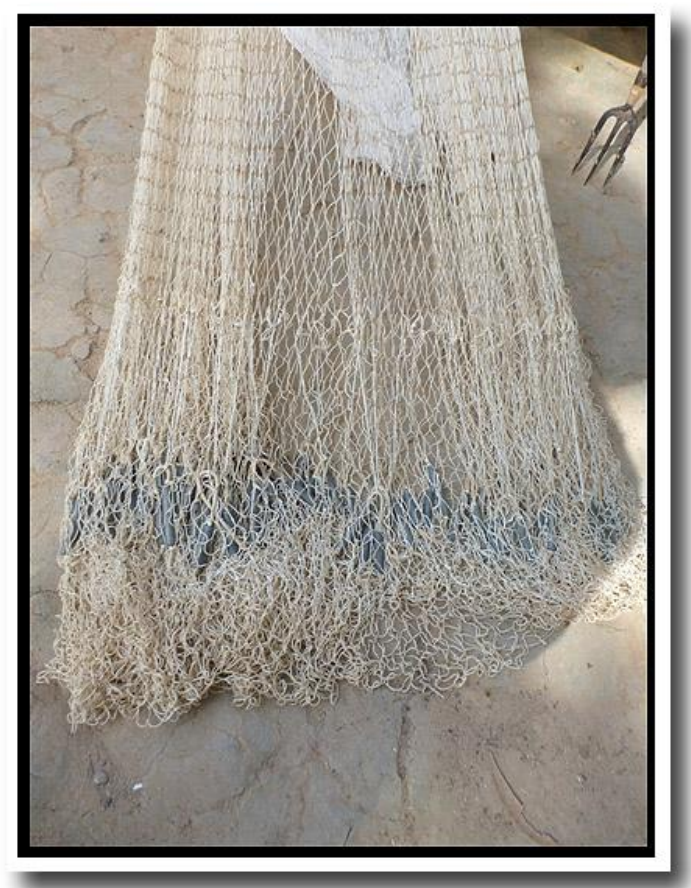

Figura 6 - Tarrafa

Foto: Camilo Ramos - out/2012

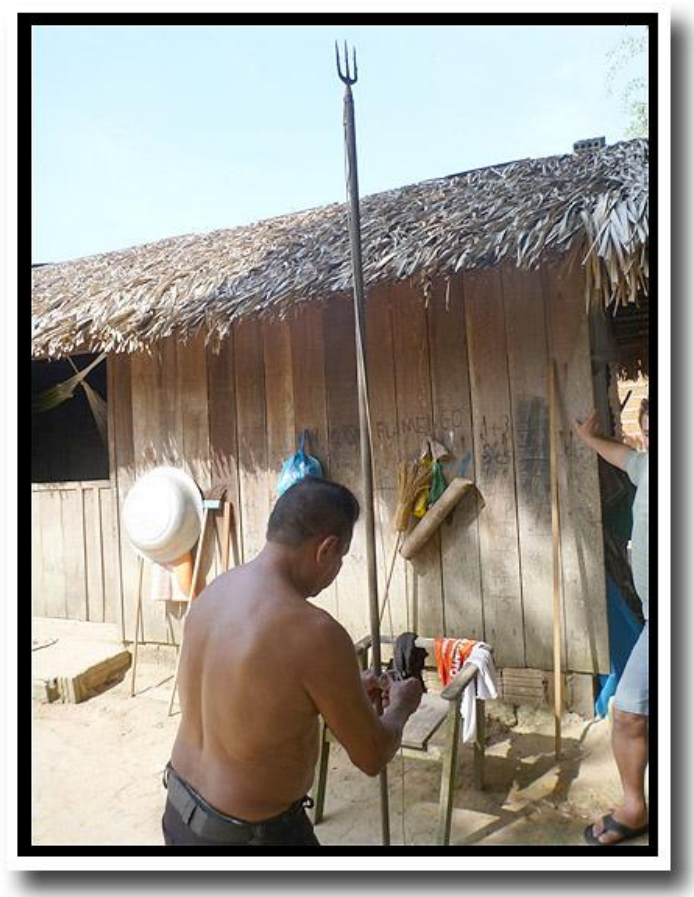

Figura 7 - Pescador armando a zagaia - tridente Foto: Camilo Ramos - out/2012

O ribeirinho reúne elementos culturais que um simples olhar não chega a perceber a grandeza do que se utiliza. Além dos arreios de pesca, tem a canoa onde há um mecanismo para que se pudesse navegar sozinho, ou seja, a canoa pode ser dotada de quilha (pedaço de madeira que fica fixo em baixo da canoa - figura 10) ou joão-de-pau (pedaço de tábua que fica amarrado na parte detrás da canoa e é removível - figura 9), ajudando a navegar sem perder a direção. Antes dos motores, usava-se o remo. E o remo, meio de exercer força para locomover a pequena embarcação, reúne várias outras utilidades, como: prato para comer quando se está no lago; base para fazer fogo no galho do pau, quando o lago está cheio. Também serve para mexer a farinha quando está sendo torrada; como enfeite de parede ou souvenir. Elementos culturais não percebidos na sala de aula, como elementos importantes a serem associados aos conteúdos trabalhados. 


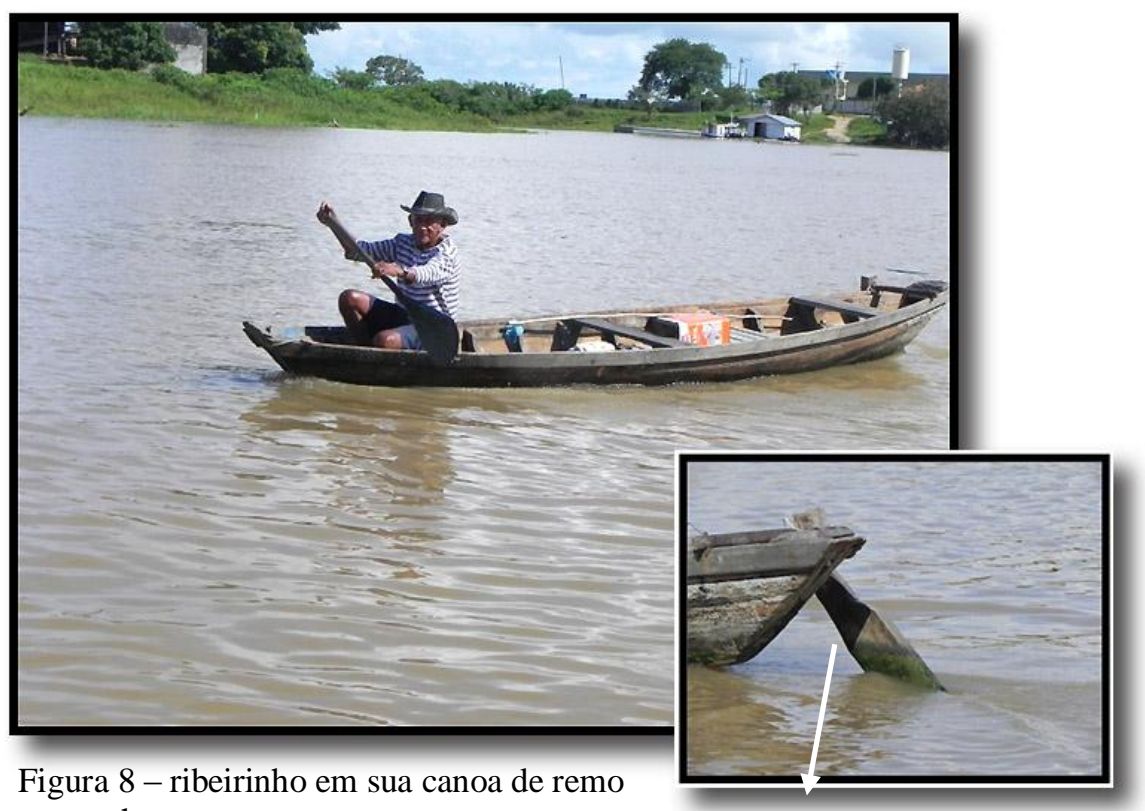
em punho.

Foto: Camilo Ramos/ 2011

Figura 9 - joão-de-pau - piloto da canoa.

Foto: Camilo Ramos/ 2011

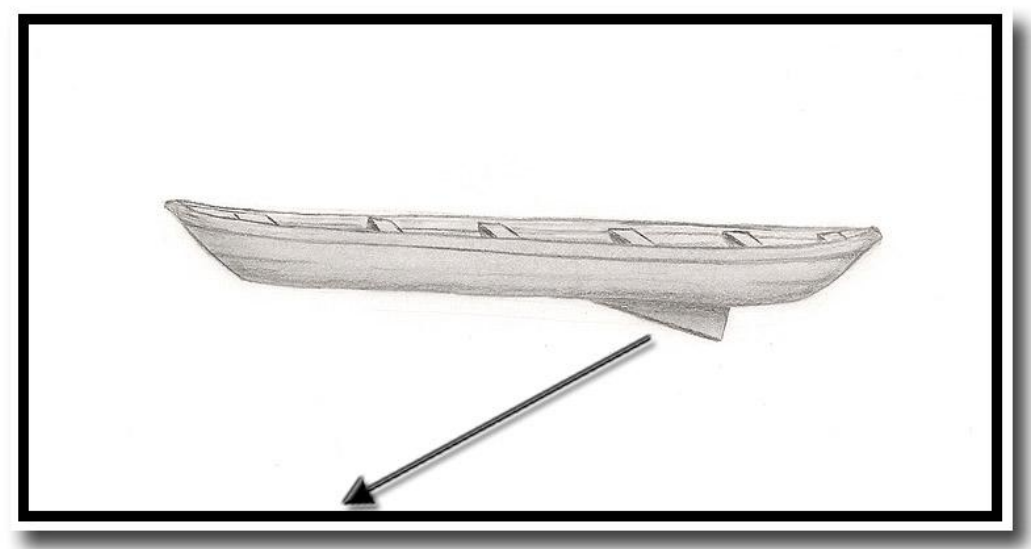

Figura 10 - Canoa - quilha - funcionando como piloto direcionador. Desenho de Claire Maria Jesus Souza - out/2012

O que é construído e ensinado no grupo social familiar são bases significativas de como historicamente os saberes são repassados aos mais jovens e ao mesmo tempo como são ressignificados e valorizados como processo estruturante da trama sociocultural que estimula e embala o saber tradicional e fortalece a identidade cultural. Este argumento se alicerça na análise de Moraes (2008b, p. 47) quando expõe sobre o tempo social e as práticas individuais na relação com o tempo da natureza. 


\begin{abstract}
Nas comunidades rurais-ribeirinhas, as áreas de plantação da mandioca, denominadas historicamente de roças; e as casas-de-farinha ou casa-de-forno ou, ainda, retiro, configuram-se em autênticos espaços de organização social, política e produtiva e de produção simbólica, aspetos que fazem desses locus de trabalho genuínos espaços de uma pedagogia do cotidiano, por meio da qual, as narrativas orais, a expressão corporal, a celebração das crenças e costumes, a afetividade, a solidariedade, a memória social e as relações com a natureza constituem-se nas raízes e nas águas que ajudam a florescer-e-reflorescer autênticas tradições, saberes e valores e, por conseguinte, o sentimento de pertença dessas populações ruraisribeirinhas amazônicas. (grifos do autor)
\end{abstract}

Estas relações apresentadas por Moraes dão a dimensão do ribeirinho com sua multiplicidade de fazeres e construções culturais, representativa de dinâmicas diferentes dentro dos dois geossistemas amazônicos: várzea e terra firme, bem significativa das Amazônias contidas nas representações socioculturais e ambientais. Nas representações socioambientais, no fazer das roças, encontram-se elementos fundantes de conhecimentos que poderiam ser associados aos conteúdos trabalhados na sala de aula. Dentre eles, a divisão social do trabalho, extremamente segmentada nas funções dos integrantes da comunidade. A tarefa de distribuir água aos mais velhos cabe às crianças. Os mais velhos exercem a função de administrar o trabalho, tanto que no plantio da maniva (pedaço da árvore do tubérculo mandioca) a mulher deposita o pedaço de maniva na cova e puxa a terra com os pés para cobrir. O jovem, com a enxada, faz as pequenas covas para o plantio.

Outro aspecto importante a ser observado é o saber construído na prática cotidiana, por exemplo, o jovem que trabalha fazendo a pequena cova, apesar de estar com um grande chapéu de palha, camisa de manga longa (comprida), calça e tênis - protegendo todo o corpo dos raios do sol - meia hora depois do trabalho pesado no sol escaldante da Amazônia, pára e vai se deitar à sombra de uma árvore como se estivesse dormindo. Nesse momento é até possível passar alguém vislumbrá-lo como "preguiçoso" sem entender a lógica que o levou ao descanso. Esta parada é de fundamental importância para que continue vivo, porque no momento em que está trabalhando, fazendo um exercício frenético, sua frequência cardíaca aumenta e se continuar pode enfartar ali mesmo. Sabendo quando aumenta sua frequência cardíaca, faz a parada a cada 30 ou 40 minutos.

Antes da realização deste trabalho familiar ou coletivo Moraes (2008b, p. 49) apresenta o processo que antecede este momento de plantação, como uma das lógicas existentes na Amazônia e constituidoras de saberes. 


\begin{abstract}
Para a realização do cultivo da mandioca e da produção de farinha, por exemplo, os/as trabalhadores/as rurais-ribeirinhas primeiramente roçam, depois fazem a derrubada de uma área da floresta. Em seguida, queimam, para, num outro momento, fazerem o plantil da maniva. Os instrumentos de trabalho utilizados, nessa primeira etapa, são: o machado, terçado e enxada. A moto-serra, quando existe, é usada para facilitar e adiantar a derrubada do capoeirão de todos os trabalhadores da comunidade, haja vista que uma ou outra comunidade a possui. (grifo do autor)
\end{abstract}

Um aspecto que faltou ser descrito por Moraes foi a forma de como protegem a floresta quando ateiam o fogo para queimar a área derrubada: o aceiro. Utilizando-se de terçado e machado, passam a cortar todos os galhos e troncos das árvores derrubadas que estão em contato direto com a floresta, procurando afastar dois metros aproximadamente, depois ateiam fogo. Após terem feito a queimada, antes de começarem a trabalhar no terreno, fazem a coivara, ou seja, passam a reunir os galhos grandes e pedaços dos troncos que sobraram da primeira queimada e transformando-os em novas grandes fogueiras separadas, para deixar o terreno bem limpo e assim facilitar o plantio da mandioca, do milho ou de outras cultivares. Importante destacar que muitos dos plantios de mandioca são consorciados com outras culturas agrícolas, como mamão, milho ou banana. Esta é uma lógica aprendida com a floresta por compreender a autodefesa da mesma pela heterogeneidade. Assim, ao plantar de forma consorciada, defende sua produção das pragas.

\footnotetext{
Geralmente, no sistema agroflorestal de produção o principal fornecedor de alimentos energéticos para a sustentação diária dos agricultores são os produtos oriundos das roças ou cultivos de roça. São as paisagens onde parcelas são cultivadas anualmente, em regime de monocultura, rotação ou consórcio. Vários são os arranjos paisagísticos encontrados, onde a produção de diversas espécies pode ser verificada, ocorrendo diversidade de variedades intra e inter-espécie, manifestando diversidade biológica. (NODA, SANDRA et.al., 2007, p. 32).
}

Esta prática de cultivo é utilizada tanto na terra firme como na várzea e em toda sua obra, Noda (2007) demonstra como o ribeirinho trabalha o solo e como consorcia suas plantações dentro e fora do conhecimento técnico agronômico. Expõe ainda, que o cultivo de espécies alimentares, em consórcio ou monocultivo, são diversificados considerando a necessidade de consumo dentro da unidade produtiva, também produzindo para a comercialização. A produção de várzea é sempre intermitente e a de terra firme é perene.

A prática de produção agrícola também está associada ao que se denomina indústria caseira, onde o pequeno produtor fabrica determinados produtos para consumo próprio e também para a comercialização. Produtos como mel de cana, rapadura, mais de 15 
subprodutos da mandioca (isto na terra firme), mas esta prática foi sendo alterada no tempo e, existindo e resistindo, somente a produção de farinha.

$\mathrm{Na}$ várzea, fazia-se doce de casca de melancia, de jerimum e de outros produtos cultivados. Durante a pesquisa não foi mais observada esta prática. Isto demonstra que muitas das características do trabalho e da produção agrícola foram sendo alteradas ou substituídas por ações assistencialistas implantadas como políticas públicas, políticas de governo. Estas políticas podem ser exemplificadas na várzea, antes das enchentes. Os moradores sempre construíram balcões suspensos para plantar cheiro verde e outras espécies utilizadas no tempero do alimento. Também pescavam e salgavam o peixe, deixando-os em um jirau suspenso sobre o fogão de lenha, para ser consumido quando a enchente não possibilitasse mais a pesca. Esta prática foi substituída pela sacola de rancho ou cartão que dá um valor de $\mathrm{R} \$ 300,00$ (trezentos reais) para passar seis meses. Em sua prática tradicional nunca o ribeirinho ficou sem alimento. Já com este tipo de ajuda, sempre reclama que a ajuda do governo não foi suficiente. Dessa forma, o comportamento social dos ribeirinhos é alterado em decorrência do que se apresenta como novo, mas por um momento algumas das práticas tradicionais são recuperadas.

Então, o delineador do arcabouço teórico sobre o ribeirinho e a sua construção de vida está na sentido de contribuir para a leitura e consistência científica dos sujeitos que aprendem observando os fenômenos naturais da Amazônia e por fazerem parte do lugar que se integram ao processo de construção e fortalecimento da identidade cultural. Em face do que foi exposto e argumentado sobre as construções ribeirinhas, procurou-se evidenciar os conceitos de identidade e cultura de ribeirinho, a partir de suas relações de trabalho e de convivência com as realidades amazônicas. Da enchente ao modo de produzir para viver e sobreviver, destacando os saberes tradicionais tendo como referência os conteúdos curriculares, bem como destacar a categoria geográfica lugar para que haja compreensão do processo de construção de conhecimento e da identidade do estudante a partir da relação escola, ensino $e$ comunidade, sem perder o entendimento do currículo, do cotidiano e dos saberes tradicionais existentes no Município de Parintins.

Ainda, e de acordo com Fraxe (2004, p. 19) “[...]. As manifestações das práticas culturais do mundo ribeirinho espraiam-se pelo mundo urbano, assim como aquela é receptora das contribuições das práticas culturais urbanas. Interpenetram-se, embora o habitus estruturado de cada uma seja relativamente distinto" (grifo da autora). Este encaminhamento é feito para que se possa desmistificar o que foi instituído como homogêneo, mesmo porque, 
segundo a mesma autora, não há homogeneidade e nem unidade entre o ecossistema de várzea e os caboclo-ribeirinhos, há inteireza no sistema amazônico do ribeirinho de várzea e de terra firme no processo de construção de muitos saberes quando passa a viver aprendendo nas suas múltiplas formas de interpretar e aprender na dinâmica dos rios, lagos, igarapés e rios.

O encaminhamento dado por Fraxe sobre cultura e identidade cabocla-ribeirinha da Amazônia é importante para entender as relações e representações ribeirinhas, sejam de várzea ou terra firme, ou seja, cada lugar com sua singularidade dentro da particularidade. É importante destacar que a identidade ribeirinha não está determinada a um único lugar, mas a todos os lugares amazônicos conhecidos, vividos e experienciados, construídos e construindose a partir de relações inter e intra grupo familiar, grupo comunitário em processo contínuo de pertença do lugar por se sentir parte integrante e pertencente à Amazônia. Assim, mantém o registro da base cultural que atravessa os tempos históricos como manutenção viva do constructo cultural ensinado e aprendido pelos amazônidas.

\begin{abstract}
A identidade da "cultura cabocla", como ocorre também com outras culturas, guarda relação com o registro de determinadas matrizes de pensamento e de comportamento secularmente registradas na memória social dos grupos e que gozam da condição da durabilidade e de persistência no tempo. (ID, IBID, 2004, p. 23 - aspas da autora).
\end{abstract}

Nestas palavras-síntese fica evidente como as relações identitárias amazônicas estão, no tempo, dinamicamente vivas no pensamento social e geográfico de quem as construiu, como sujeito que aprendeu a viver conhecendo os fenômenos amazônicos, a partir de muita observação e também de todo seu aspecto heterogêneo de vida dentro do contexto sociocultural e socioeconômico.

Neste encaminhamento, Witkoski (2007) procura discutir e apresentar conceito de caboclo e de ribeirinho. O conceito retrata a ocupação das várzeas pelos indígenas Omaguás, que viviam as margens dos rios e, dessa forma, sendo ribeirinhos e conhecedores das várzeas e de sua utilização. Aponta também o processo histórico de ocupação da Amazônia pelos primeiros colonizadores: espanhóis e, posteriormente, portugueses, no sentido de mostrar os matizes do caboclo amazônico. Para aprofundar a argumentação sobre o conceito de caboclo e de ribeirinho, no contexto da cultura, apossa-se dos pensadores Câmara Cascudo, Vianna Moog, Charles Wagley, Marshal Sahlins, respaldando a compreensão do conceito apresentado. 
Diante dessa pequena arqueologia do termo caboclo, deixando de lado possíveis dimensões positivas e/ou negativas que sua representação social carrega - caboclo é o sujeito oriundo da floresta, é o tapuio compreendido como o ameríndio domesticado (manso), é a pessoa desconfiada, é o ser que possui resistência e perseverança, não é uma pessoa ambiciosa, é o homem que possui notável instinto de aproveitamento dos recursos naturais e de defesa - o que é ser caboclo? Ser caboclo é ser esse conjunto de significados. Ser caboclo, nos parece, é ser também uma multiplicidade de seres, é um devir que sempre incorpora novas significações. É, certamente, antes de tudo, miscigenação de brancos com índios! Mas não é só isso. Não poderia ser e não é só isso. É uma reunião de coisas próximas e/ou opostas, como mostramos, porque é um composto biológico, social e cultural de representantes de duas civilizações antagônicas. Mas não é só isso. É, também, de modo mais recente, o resultado da mistura de parte da população do Nordeste brasileiro (os sertanejos) com populações amazônicas - o que dá novos matizes a esse ser e a seu modo de ser. (WITKOSKI, 2007, p. 93-94)

Fica evidente a construção do conceito de caboclo-ribeirinho exposto por Witkoski, por ser herdeiro de processo de miscigenação, guardador da herança cultural e conhecedor do ambiente onde mora e vive, como ficou evidenciada a estruturação do sentimento de identidade cultural. Nesta perspectiva de construção e compreensão do conceito do caboclo e de ribeirinho, Djalma Batista (2003, p. 71) reforça fazendo a afirmativa: "Evidentemente houve uma súbita transformação no processo cultural da Amazônia: a miscigenação se apressou, entre o caboclo - descendente do índio com o branco - e o mestiço imigrado, saído do melting-pot nordestino, entre o branco, o negro, o mulato, o índio, o zambo-cafuz e o curiboca; [...]". 


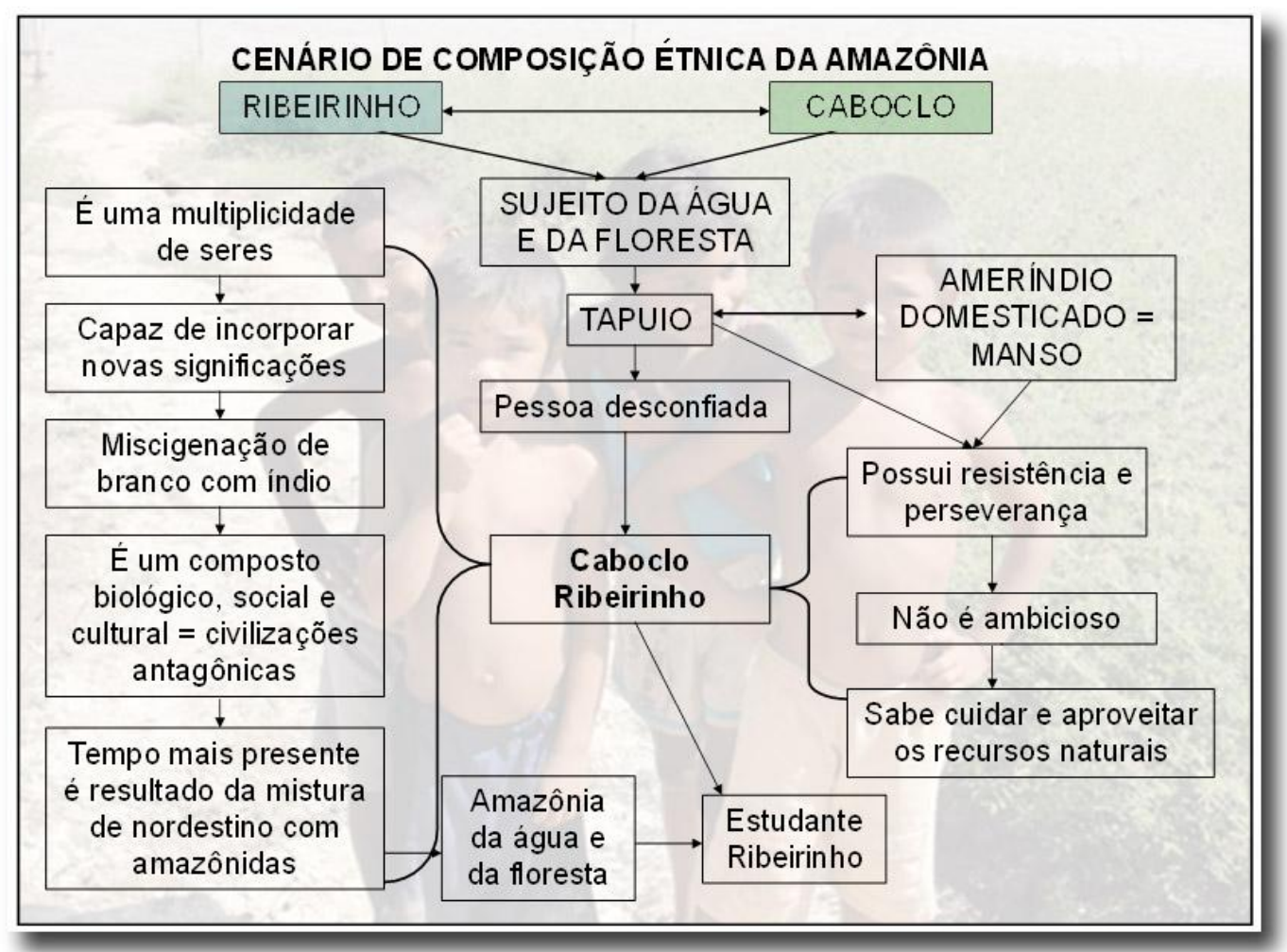

Figura 11 - Cenário de Composição Étnica da Amazônia Organizado por Camilo Ramos

As representações do cenário de composição das origens evidenciam os processos construtores do que foi exponenciado tanto por Witkoski quanto por Djalma Batista, ressaltando o termo caboclo e acrescentado o termo ribeirinho, por incorporar a cultura e o modo de vida herdada da prática dos indígenas habitantes dos rios de água branca, onde estão concentradas as várzeas e também por ser um grande reservatório de peixe. $\mathrm{O}$ termo caboclo traz os matizes da herança do cruzamento físico do branco com o indígena e posteriormente foi acrescentada a participação dos imigrantes nordestinos que chegaram a Amazônia, trazidos pela febre da exploração da borracha.

É importante destacar que esta composição étnica do caboclo amazônico, resultado de um processo histórico de miscigenação, já foi tratada de forma pejorativa sendo considerado como atrasado, analfabeto, apático, indolente e considerado como o principal responsável pelo seu estado de pobreza. Hoje o termo caboclo já está sendo aceito porque foi exaltada a riqueza de saberes que o ribeirinho ou amazônico possui, por sua autonomia na sua forma de ser e de existir no lugar. O caboclo aprendeu a obter o que precisa da floresta e do rio e assim não aceita ser empregado, a não ser que se sinta livre, pois, a liberdade é essencial ao seu modo de vida. Nesta tese, o termo utilizado vai ser sempre ribeirinho amazônico ou 
ribeirinho - da água (várzea) ou da terra e floresta (terra firme), não no sentido de negar o processo de construção étnica mas o de fortalecer o sujeito construtor de si mesmo e de sua história.

Ainda, na discussão de identidade, de acordo com Castells (2002, p. 45) "a identidade é a fonte de significado e experiência de um povo, com base em atributos culturais relacionados que prevalecem sobre outras fontes". Não se deve confundi-la com papéis, pois estes determinam funções e a identidade organiza os significados. A construção da identidade depende da matéria prima proveniente da cultura obtida, processada e reorganizada de acordo com a sociedade.

Nesta linha de raciocínio sobre identidade há também a forte posição de Tomaz Tadeu da Silva (2011, p. 54) quando discute identidade e subjetividade no sentido da percepção e aceitação do seu eu, a partir do seu próprio reconhecimento pessoal.

\footnotetext{
[...]. A subjetividade envolve nossos sentimentos e pensamentos mais pessoais. Entretanto, nós vivemos nossa subjetividade em um contexto social no qual a linguagem e a cultura dão significado à experiência que temos de nós mesmos e no qual nós adotamos uma identidade. Quaisquer que sejam os conjuntos de significados construídos pelos discursos, eles só podem ser eficazes se eles nos recrutam como sujeitos. Os sujeitos são, assim, sujeitados ao discurso e devem, eles próprios, assumi-lo como indivíduos que, dessa forma, se posicionam a si próprio. As posições que assumimos e com as quais nos identificamos constituem nossas identidades. [...].
}

Há de ser considerada a disputa pelos valores existentes em cada grupo social e também nas suas diferenciações pessoais e grupais, por ser um elo estabelecido na relação de poder do qual a identidade é definida marcando a diferença, as quais não são inocentes, em todo seu processo de construção e firmação (SILVA, 2011). Aspectos importantes discutidos e condutores de compreensão da identidade como processo dinâmico pessoal, cultural e político, pois, segundo Stuart Hall (2005) esta sempre em processo contínuo de construção a partir das relações familiares e da vivência em sociedade, que vai sendo edificada a partir de complementação exterior na relação do $e u$ com o outro, estruturando o sentimento de pertença.

Esta forma apresentada da construção da identidade do sujeito remete ao seguinte questionamento: quem é mesmo o ribeirinho? Pode-se dizer que ribeirinho é o sujeito construtor de si mesmo e de sua trajetória histórico-espacial. É o artesão de conhecimentos tradicionais apresentados em seus instrumentos de pesca, de caça, de trabalho e de outros utilizáveis em sua residência. É o que aprendeu observando os fenômenos naturais para, em 
processo de adaptação, viver sazonalidades dos rios, como também saber conservar os recursos naturais para ter sempre. Aprendeu a contar os peixes nos lagos, em um verdadeiro esquema mental de construções matemáticas e também de acurada observação de locais onde se encontram as populações de determinada espécie de pescado. É quem traz, junto de si, toda experiência de trabalhar na terra, seja na várzea ou terra firme. É um composto de pequeno agricultor, pequeno criador, pescador, extrator de recursos vegetais, coletor e conhecedor das ervas, resinas vegetais, cascas e outros produtos naturais que compõem a farmácia natural da Amazônia. Assim sendo, é o compositor de sua trama, do tecido de vida e da identidade cultural onde aprendeu a construir construindo-se com o seu fazer, com a sua experiência do viver e também com a forma de aprender e ensinar, em processos contínuos dos seus saberes tradicionais.

Ademais, no contexto educacional, é perceptível a reprodução das tipologias de identidades expostas (não as dos ribeirinhos especificamente) a partir do desdobramento do currículo, que para muitos professores é entendido como programas de ensino, conteúdos ou matriz curricular (esta referência se faz a professores de comunidades ribeirinhas da Amazônia e não a todos os professores do Brasil). Na realidade existe uma pluralidade de definições e cada uma pressupõe valores e concepções implícitas. Dessa forma, os conteúdos escolares poderiam ser sempre ressignificados pelos estudantes das escolas das comunidades ribeirinhas.

\subsection{Lugar de vida: comunidades ribeirinhas amazônicas}

A forma de pertencimento em uma comunidade ou em um lugar, remete a um momento pretérito para perceber o processo e a forma de construção das relações socioculturais determinadoras e legitimadoras do uso do lugar como construção de vida. Isto está ligado ao processo de construção da identidade bem como de todo processo de estrutura das relações de poder e disputa pelos recursos naturais importantes ao núcleo social, para que continue existindo e fortalecendo seus laços coletivos e comunitários. Na visão de Hall (2005) e de Claval (2010) estes laços ultrapassam o real, chagando a ser visto como imaginário por possuírem símbolos e representações, por darem sentido e significado de vida, processo de construção de identidade e cultura. Hall (2005, p. 52) diz que "[...]. Como membros de tal "comunidade imaginada", nos vemos, no olho de nossa mente, como compartilhando dessa narrativa. Ela dá significado e importância à nossa monótona existência, conectando nossas vidas cotidianas com um destino nacional que preexiste a nós e continua existindo após 
morte. [...]" (aspas do autor). Nesta perspectiva, a visão é direcionada para o lugar detentor da origem de todas as manifestações da tradição, e como esta é trabalhada, para ter sempre continuidade, fortalecendo a identidade não só local, mas a nacional. Para Claval (2010) discutir os espaços imaginados é pensar os espaços não formais em sua formalidade de totalidade na perspectiva da parcialidade, tornando-se lugar existente na imaginação, transformando-se em real no percurso da construção de seu lugar de vida e de sua identidade cultural.

Diante da discussão, é importante destacar que o lugar de vida ou comunidade ribeirinha amazônica não se refere a parte física mas ao lugar vivido, construído no dia a dia a partir das relações sociais, culturais, históricas e que constrói e ressignifica quem o construiu. Esta ressignificação só ocorre porque passa a ter um significado de vida diferente e exige um novo olhar de dentro do lugar mantenedor do sentimento de ser, de pertencer e de se deixar envolver como parte integrante, por estar latente dentro de cada sujeito participante dessa construção de relações de vida comunitária amazônica. Este sistema pode ser entendido como o esquema corpóreo apresentado por Bettanini (1982), quando questiona uma visão geométrica como parte do espaço vivido, por compreender que o espaço vivido é determinante para se ter qualidade e não quantidade.

Fica evidente a demonstração das relações heterogêneas dos sujeitos por serem partes de suas próprias construções cotidianas, como pode ser exemplificado: a canoa e o remo fazem parte do corpo do ribeirinho de várzea e do de terra firme. A canoa, nesta exemplificação, passa a representar os pés no processo de locomoção de um lugar para outro pelas estradas fluviais amazônicas. O remo, como representasse os braços e mãos - uma extensão do outro e todos se completam. Nesta perspectiva, deixa fluir reflexões acerca das relações culturais por serem componentes importantes para que o estudante se sinta pertencente ao lugar, quando passa a valorizar cada elemento.

Nesta dinâmica sócio-coletiva, os elementos culturais construídos no processo históricos, ligados ao cotidiano e assim na vida de quem o construiu, são bases de aprendizagem a partir de toda relação de convívio dentro e fora do lugar, na relação pertencente do ser humano com a água e a floresta, presente na afirmação de Cruz (2007, p. 8)

Portanto, rio e camponês-ribeirinho são partes de um todo. Se o rio oferece os seus alimentos, fertiliza as suas margens no subir e baixar das águas, o camponêsribeirinho oferece sua proteção, por meio de suas representações (seus mitos), como a mãe-d'água, a cobra grande que come os desavisados (que não respeitam a natureza) e tantas outras, que nascem desta relação dialética da humanização da natureza e naturalização do homem. 
Na relação dialética exposta por Cruz, a água com a terra são expressões de vida em processo contínuo de caracterização do todo do ribeirinho, por tentar conhecer o desconhecido amazônico para impor suas ações de vivência dentro das regras naturais, como sendo parte do risco de vida na sazonalidade do rio ou nas caçadas na floresta em busca do alimento familiar. Silva, Gláucia (2000, p.28) mostra o cotidiano de pescadores no mar, evidenciando o quanto é significativos suas relações com a natureza, quadro de reflexão comparativa ao vivido pelo amazônida.

\footnotetext{
Os pescadores compreendem a natureza em dois grandes mundos: o do mar e o do seco, sendo que o primeiro é tido como um espaço muito especial, digno de muita reflexão e admiração. Este mundo construído em torno do mar, engloba também céu, nuvens, chuvas e ventos que passam vir compor o cenário do homem embarcado. O mundo do seco constitui-se de uma natureza dócil, previsível, possível de ser controlada no que diz respeito a certas leis e ciclos e, na medida em que a sociedade é vista como uma dimensão deste mundo, as regras sociais também reforçam esta expectativa de previsibilidade.
}

Na Amazônia, tanto no mundo das águas (rios, paranás, igarapés, lagos) quanto o das florestas, os entes mitológicos são respeitados pelos ribeirinhos. Nesse universo, esses seres que povoam o imaginário popular gozam do mesmo respeito que os pescadores do mar têm por suas entidades. Essa relação, de forma geral, diferencia-se pela imposição ou pelo respeito. Os ribeirinhos da várzea e da terra firme compreendem o limite existente na extração dos recursos naturais. Todavia, muitas vezes, há extração além das suas necessidades, tornando-se assim um perigo para o equilíbrio do sistema. Diante disso, as entidades se manifestam impondo o controle que possuem sobre cada ambiente. A cobra grande - um dos seres das águas - faria "desaparecer" determinados tipos de peixe como punição. Já o curupira, um dos seres da terra firme, faria o ribeirinho perder-se na floresta, que terá que utilizar de meios para desviar a atenção do protetor da floresta e assim conseguir retornar à sua casa. Percebe-se, neste movimento de relações antrópico-naturais, que os saberes vão sendo construídos para darem explicações aos mistérios existentes em cada lugar de vida. Como uma maneira de estarem sempre se preparando para eventos naturais inesperados, tanto dentro da água como na terra e floresta.

Noutra perspectiva de lugar de vida ou comunidades ribeirinhas existentes dentro da Amazônia, encaminha a compreensão de sua heterogeneidade, tanto do ponto de vista natural quanto antrópico, formando unidade na sua complexidade. A heterogeneidade natural se apresenta na estrutura diversificada de rochas, solos, rios, relevo, florestas e na dinâmica 
climática, não sendo regra. A característica de unidade se apresenta por manter a harmonia de todos os elementos naturais de forma sistêmica, produzindo a biodiversidade (SALATI, 1983). A heterogeneidade humana está no processo de ocupação da região desde a colonização até o momento atual. Deste processo resultou a formação do caboclo-ribeirinho, aprendendo a viver em harmonia por ser parte da floresta e do rio, herdeiro dos ensinamentos dos povos indígenas da Amazônia, segundo Witkoski (2007).

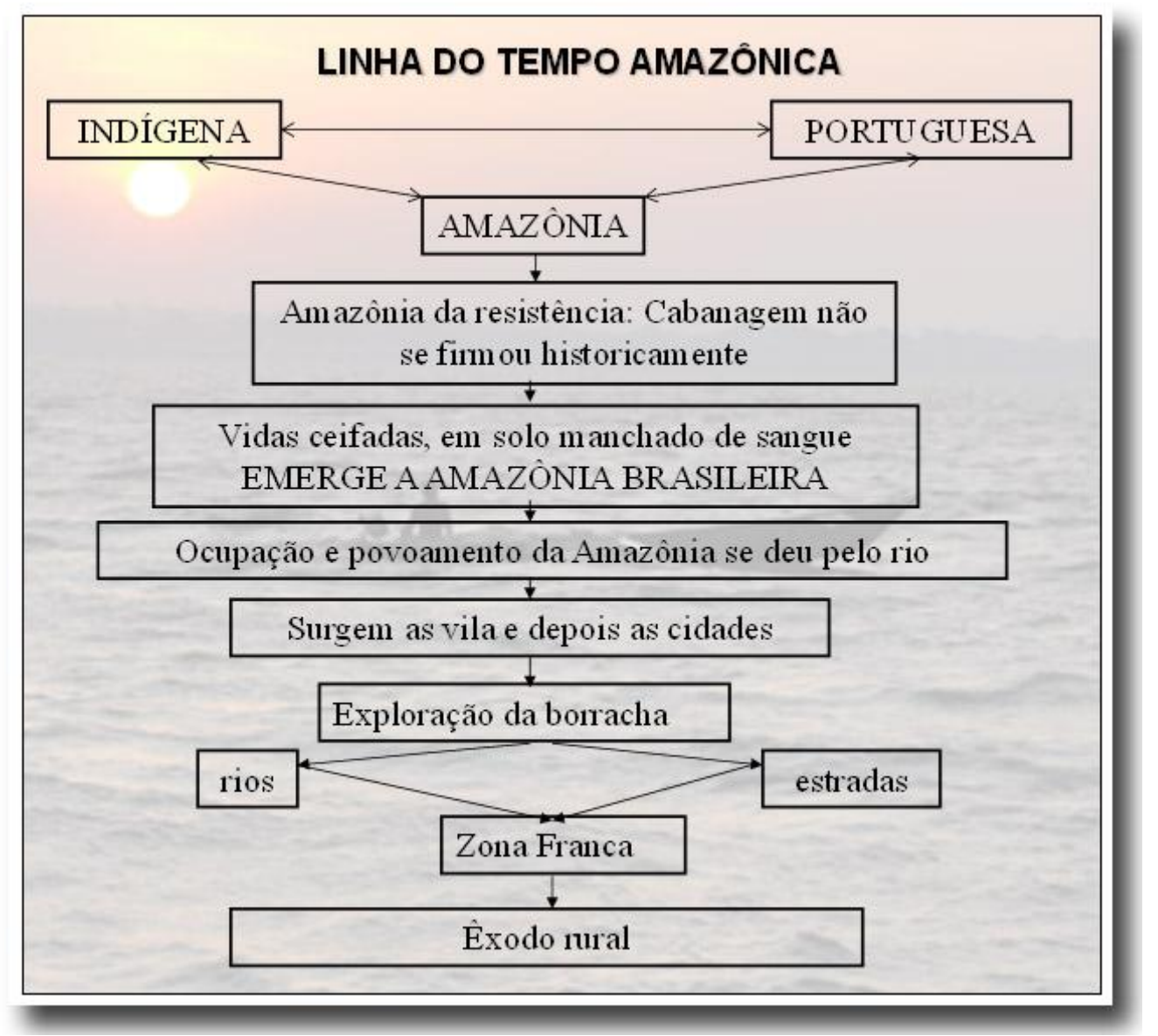

Figura 12 - Linha do Tempo Amazônica Organizado por Camilo Ramos

Esta configuração, de formação e transformação da Amazônia, está presente na particularidade das comunidades ribeirinhas, herdeiras de um processo histórico refletido no eu do sujeito intimamente ligado ao lugar, por toda sua sensibilidade de vida, principalmente por estar sempre rompendo as imposições e acompanhando as mudanças exteriores - algumas aceitas ou outras não - demonstrando sempre sua capacidade perceptiva a partir de seus sentidos onde ressignifica o que lhe é importante dentro de tudo que foi percebido no seu lugar de vida. É importante salientar que o sujeito ribeirinho está sempre aberto a tudo que é 
produzido. Não se fecha ao novo, mas mantém seu elo de resistência para não perder seus elementos históricos tradicionais. Todas estas relações sociais, econômicas, ambientais estão a partir da percepção cotidiana, ou seja, como percebe o seu lugar de vida.

É por isso que o tema da percepção do espaço - a partir do espaço do corpo para englobar os territórios da vida quotidiana - não pode deixar de lado o problema daquilo que se percebe e do modo como se perceber; e, mais explicitamente, da relação entre sujeito da percepção e conteúdos desta, de um lado, e gestão destes mesmos conteúdos, de outro lado. (BETTANINI, 1982, P.129 - grifo do autor).

Quando o sujeito se percebe na comunidade ribeirinha como membro do tecido construído no lugar comum a coletividade, onde os interesses são voltados para o bem de todos os membros, sobressaindo às vontades individuais, que são tiradas a partir de assembleias, passando a entender o sеи еи e sabe que não é sua vontade pessoal que deve ser respeitada. Além do mais, entende que a ajuda mútua é um elemento importante e que não pode desaparecer mesmo que a lógica capitalista exija um novo comportamento social. A cobrança pelo dia trabalhado, isto não é determinante. Há, em alguns casos, cobranças por determinados serviços, mas quando é tirado em assembleia o trabalho coletivo em prol comunitário, a decisão passa a ser respeitada. Isto evidencia a relação de poder existente na comunidade e os embates conflitantes a partir das forças externas projetadas nas forças internas, influenciando negativa ou positivamente as relações socioculturais da comunidade. Bem exemplificado nas palavras de Charles Wagley (1988, p.43), quando trata de "uma comunidade amazônica", demonstra a vida, a singularidade de cada comunidade e as suas múltiplas interações a partir de seu modo de vida amazônico.

Wagley procura mostrar a complexidade estabelecida nas múltiplas relações existentes em uma comunidade amazônica e, na tentativa de estudar o todo, não conseguiria entender a sua forma e a sua função se não integrasse à vida da comunidade. Mesmo porque há singularidades funcionando, como elo ou força de resistência a todas as influências externas, exigentes de mudanças internas, principalmente em determinados comportamentos pessoais ou mesmo coletivos. Por isso, estudar uma ou duas comunidades amazônicas é um grande desafio, pois, por mais que se destinem todos os esforços, não revelaria a complexidade da organização sócio espacial, onde há um intricado sistema socioeconômico, cultural e ambiental. É importante ressaltar e afirmar que as comunidades ribeirinhas amazônicas não se encontram isoladas, mas sim em um lugar distante em inteira comunicação com tudo que está sendo produzido regional, nacional ou globalmente. 
Vale ressaltar outro aspecto de resistência: são as relações de parentesco, onde a palavra do mais velho ainda é respeitada. Este é detentor de saberes construídos historicamente. Os mais velhos percebem as influências externas e não se deixam influenciar totalmente com a chegada da igreja (fixador do santo no lugar), das políticas de governo (mudando o modo de vida ribeirinho de preparação para as cheias ou as vazantes do rio Amazonas). Procura fortalecer os laços de pertencimento para não permitir a destruição ou abandono do lugar de vida. Neste lugar há sentimentos guardados, há lembranças do passado fortalecendo o presente, há familiares sepultados que não podem ser abandonados; aspectos determinantes da implantação e fixação de sua própria vida nas relações com o rio e com a floresta - porque é integrante do sistema maior.

$\mathrm{Na}$ relação homem natureza, fica evidente que a vida do ser humano e de outros seres depende do ambiente equilibrado. Esse equilíbrio permite a harmonia melódica da floresta e do rio, usufruídos pelos amazônidas. Esses amazônidas fazem defesa do ambiente amazônico por saber que a vida da floresta e dos lagos depende da conservação da região e para tanto, do empenho de todos os sujeitos da floresta. Então, o desafio da preservação e conservação dos recursos florestais e aquáticos amazônicos está presente nos ensinamentos do grande defensor e decifrador dos mistérios: o ribeirinho da água ou da terra e floresta e seus filhos estudantes da escola, por compreenderem cada manifestação da natureza, onde expressa seu respeito. Esse ribeirinho (pescador, extrator, cultivador, pequeno criador, artesão) procura defender o ambiente equilibrado para que as gerações atuais e as futuras possam usufruir tudo que ainda existe na Amazônia.

Diferentemente de outros lugares do Brasil, a região amazônica traz, nas margens dos rios, as cidades. Representação de toda organização do espaço socialmente construído, não sendo totalmente amazônicas, pois são tipos de cidades importadas, como expressou Wagley (1988), são resultados também de inúmeras influências externas processadas internamente.

As comunidades ribeirinhas amazônicas seguem o mesmo padrão de organização espacial onde o templo religioso fica bem ao centro, ostentando a relação de poder. Porém muitas comunidades alteraram seu padrão de acordo com as necessidades de seus moradores, expressando a simplicidade dos ribeirinhos que a construíram e que, em cada pedaço de chão há uma parte de quem a construiu.

O lugar de vida é um grande laboratório para ensinar e aprender a viver em todos os aspectos geográficos pela diversidade de aspectos naturais, socioculturais e socioeconômicos. Nem tudo pode ser aprendido mesmo estando e vivendo no lugar, por serem muitos os 
elementos geográficos que os envolvem. Então, é na beira do rio e nestes lugares - terra firme ou várzea - que o ribeirinho aprendeu a aprender experimentando, para ter certeza, que sabe viver na relação harmoniosa com o rio e com a floresta, por ser um elemento da heterogeneidade social e natural amazônica. Lugar amazônico, que o pai ensina aos seus filhos na singela e pura simplicidade de seus saberes herdados dos seus ancestrais.

\section{$2.4 \quad$ Terra firme e várzea}

Discorrido sobre múltiplos aspectos amazônicos, adentra-se neste momento em duas particularidades físicas: terra firme e várzea - que são como leituras diferentes em sua complexa formação, como livros ou documentos carecendo de decifração para serem compreendidos e por permitirem que o ser humano possa usufruir cultivando, coletando, construindo vasilhas e inúmeros objetos necessários à sua vida, retirados do solo ou da floresta.

A finalidade desta discussão não é apresentar uma análise de várzea e terra firme como já foi realizado por inúmeros pesquisadores, mas conduzir à possibilidade de tê-las como recurso didático no processo de ensino aprendizagem da geografia, entre os saberes escolar e o tradicional, tendo em vista que os dois ambientes são lugares que parecem ser homogêneos e uniformes, para quem os observa do ponto de vista do espaço geométrico. Ao olhar do ponto de vista do espaço geográfico, percebe-se que são diferentes e complexos, e, com a presença dinâmica do ser humano, possuem suas singularidades a partir de suas particularidades, porque, segundo Dardel (2011, p. 2) "A geometria opera sobre um espaço abstrato, vazio de todo conteúdo, disponível para todas as combinações. O espaço geográfico tem um horizonte, uma modelagem, cor, densidade. Ele é sólido, líquido ou aéreo, largo ou estreito: ele limita e resiste".

No sentido da compreensão, tanto várzea quanto terra firme, já foram e são vividos cotidianamente e por conseguinte são experimentados pelos ribeirinhos nas suas múltiplas atividades socioeconômicas e socioambientais como projeto de existência de vida por entenderem a dinâmica da Amazônia no período chuvoso e da enchente (dezembro a junho) ou o período de calor e vazante dos rios (junho a dezembro), onde planejam suas atividades agrícolas e de criação de animais.

Nessa realidade geográfica, o amazônida procura observar bastante para compreender os fenômenos naturais e prevenir suas atividades para não ser totalmente surpreendido, 
acarretando prejuízos de toda ordem, que pode ser exemplificado: no período de calor ou estiagem, os animais são mantidos na várzea. No período chuvoso e das enchentes, os animais são transferidos para a terra firme. Essa sazonalidade ou transumância, caracteriza um viver diferente na Amazônia, não sendo determinante mas um processo adaptativo de vida sobre a água e dentro da floresta.

Nesta dinâmica dialética, tanto a várzea quanto a terra firme, fazem parte da vida do ribeirinho como este faz parte e se sente integrante destes dois ambientes por compreender sua estrutura de formação, não do ponto de vista científico, mas a partir de suas observações diárias, entendendo a heterogeneidade de sua cobertura vegetal, a partir de toda sua vivência e convivência na utilização dos solos amazônicos. Em relação à cobertura vegetal, Sternberg (1998) faz a descrição detalhada da floresta de várzea, dando a devida localização e distribuição por espécie, concentradas nas margem ou não dos lagos e rios. A cobertura vegetal também representa a proteção natural contra a erosão pluvial e fluvial e possui importância tanto para vida animal terrestre quanto para a aquática.

Essa composição vegetal pode ser encontrada em toda extensão das várzeas da Amazônia, tendo - em algumas partes - espécies endêmicas (somente daquele lugar). A cobertura predominante é descrita por Sternberg. Vale destacar a utilização de alguns vegetais da várzea, cujo uso está sendo reduzido pelo desaparecimento da espécie em decorrência da transformação da floresta em pastagem para gado. Na várzea, outro motivo decorre da mudança do comportamento do ribeirinho, tais como: mugumba (Bombax munguba), possuindo casca grossa e desta se extrai uma vibra que era utilizada como cordas para amarrar cercas ou prender as embarcações de pequeno porte, ou até mesmo, corda para pendurar a rede de dormir. O pau mulato (Colycophyllum spruceanum) utilizado para fazer boia de malhadeiras ou de arpueira (que compõe o arreio de pescar pirarucu - Arapaima gigas), por ser leve e flutuar na água.

Apesar do ribeirinho de várzea utilizar-se da madeira de terra firme para fazer sua casa, faz também uso da madeira de várzea para fazer e consertar cercas, curral e a maromba no período da enchente (assoalho sobre assoalho da casa ou lugar onde ficam confinados alguns animais).

Seguindo esta discussão sobre vegetação da várzea, Junk (1983) expõe o processo de adaptabilidade dos vegetais no período da enchente e vazante, expondo a resistência da floresta de várzea que sobrevive a uma inundação de seis meses, a sazonalidade do rio Amazonas. Os vegetais conseguem mudar sua folhagem na enchente e neste processo há 
também floração, quando os frutos ficam maduros e caem na água. A água é a principal responsável pela distribuição das sementes e a grande contribuição dos peixes no processo fitogeográfico de dispersão de sementes.

Nesse ponto a Geografia se apresenta na dispersão das sementes por via aérea (eólica), por via terrestre (responsabilidade dos animais) e por via aquática (responsabilidade da correnteza e participação ativa dos peixes, principalmente o tambaqui - Colossoma macropomum). Essa dinâmica tem, na compreensão dos mais velhos, o funcionamento dinâmico da floresta, que no período da enchente serve de refúgio para reprodução de muitos animais aquáticos e produção de alimento para muitos peixes, aves e outros animais.

Ainda nesta linha de raciocínio, os pais conduzem seus filhos no entendimento das relações sistêmicas mostrando as diferenças existentes entre os extratos florestais de várzea e de terra firme. Dessa forma, as crianças passam a perceber a importância das lições de vida para entender seu lugar, a realidade regional, nacional interligada com a global e suas interrelações de influências climáticas, humanas e econômicas.

Sobre a floresta de terra firme, que é um composto diversificado de floresta, Shubart (1983) apresenta os aspectos florestais amazônicos predominantes. Essa floresta não é alagável, sendo produtora de grande biomassa. Tem uma diversidade de vegetais de grande porte, cipós, campinarana, sobre solo ácido. Esse solo é enriquecido pela decomposição de toda matéria orgânica, chegando a 30 (trinta) centímetros, caracterizando a autossustentação da grande floresta.

Essas florestas detêm madeiras de grande valor comercial que geram cobiça das madeireiras nacionais e internacionais. Contêm óleos e resinas vegetais de interesses de empresas de capital estrangeiro. A floresta também é detentora e concentradora da grande farmácia fitoterápica, promotora da investida dos grandes laboratórios nacionais e internacionais. Esta cobiça sobre a região amazônica já foi fruto de biopirataria e agora é sobre a "pirataria" dos conhecimentos tradicionais.

Em relação ao solo amazônico de terra firme, o ribeirinho da terra ou floresta, conhecedor da pobreza do solo, procura trabalhar o terreno, queimando, fazendo coivara, aceiro, preparando a terra para plantar durante um período, e depois deixar em repouso (pousio $^{8}$ ) por um longo tempo. O período de repouso permite a reposição da cobertura vegetal, chamada de capoeira. Essa atividade - de deixar a terra em pousio - decorre da prática indígena e da herança dos ancestrais. O reflorestamento ocorre naturalmente e este sistema é

\footnotetext{
${ }^{8} \mathrm{O}$ pousio se deu no primeiro momento de forma instintiva e posteriormente de forma planejada.
} 
afetado pela produção de monocultivo e exploração à exaustão do solo. Este aspecto do trabalho indígena apresentado, fica claro nas palavras de Noda, Hiroshi e Noda, Sandra (1994, p.134).

\begin{abstract}
As práticas agronômicas indígenas se caracterizavam pela coivara e queima da mata. As primeiras espécies utilizadas eram aipim e mandioca (Manihot esculentum), batata doce (Ipomea batatas), inhame (Alocacea indica), milho (Zea mays) para alimentação, algodão para tecelagem, urucu (Bixa orellana) e jenipapo (Genipa americana) para decoração.

$\mathrm{O}$ rápido esgotamento dos solos para este tipo de cultura impôs a prática de uma agricultura de pousio, que permitia a regeneração dessas áreas. Desse modo, a população ocupava grandes áreas sem destruir a vegetação natural (adaptação do homem ao meio natural) e ao mesmo tempo, amoldava este ambiente pelas suas práticas culturais (aumentando das espécies perenes úteis ao homem no interior da mata). A adaptação aos ecossistemas amazônicos empunha o habito de mudar de local, construindo aldeias, onde a garantia de subsistência fosse melhor. (grifo da autora).
\end{abstract}

Esse processo de trabalhar o solo resultou no que é hoje conhecido, dentro da Amazônia, como "capoeira velha", herança de práticas indígenas milenares. Pessoas desconhecedoras da realidade florestal amazônica pode olhar e achar que é uma floresta virgem, pelo porte das grandes árvores. Mas são árvores oriundas desse processo de regeneração do solo. Os amazônidas, pelo conhecimento obtido ou herdado, sabem reconhecer este tipo de herança florestal. Os mais velhos ou os mais experientes da comunidade, detentores de saberes sobre o lugar, poderiam ser convidados para irem à sala de aula e mostrar, na sua visão empírica, o saber historicamente construído, de como diferenciar e reconhecer a floresta virgem da capoeira velha, como reconhecer, o cipó d'água existente na terra firme, que mata a sede do mateiro, caçador ou extrator dentro da floresta. Dessa forma, o saber construído historicamente estaria sendo valorizado e ressignificado.

Em relação ao solo e produção de várzea Noda, Sandra (2007), em seu livro Agricultura Familiar na Amazônia das Águas procura mostrar todo processo de produção agrícola e o uso do solo pelos ribeirinhos, que também praticam o cultivo em balcão suspenso para terem produção no período da enchente. A produção da várzea é para o consumo e comercialização, sendo cultivos de ciclo rápido para que a produção não seja perdida por causa da enchente. 
Em relação à enchente, Sternberg (1998, p.42) faz a seguinte descrição:

[...]. Aqui, as águas, por via de regra, sobem mansamente, levando cerca de oito meses para atingir o auge, e vazam em apenas quatro. Em abril, a subida se faz, em média, à razão de 5,1 cm por dia; em maio e junho, a progressão se torna ainda mais lenta, à medida que o nível dos rios se aproxima de sua cota máxima. A regressão se faz muito mais rápida (e já vimos porque); assim, sem setembro, as águas baixam, em média, $12,7 \mathrm{~cm}$ por dia. Esta configuração da curva traduz um fator favorável ao aproveitamento da várzea: o lavrador dispõe de mais tempo para recolher suas safras à subida das águas e estas liberam as terras mais prontamente para o ano agrícola seguinte. [...]

Esse processo do regime do rio Amazonas é muito importante para a fertilização da várzea porque ocorre a deposição de sedimentos ricos em nutrientes, resultados de um conjunto de matéria orgânica e sedimentos de origem mineralógica, segundo Salati, Junk e Shubart (1983) o solo de várzea se renova (figura 13) a cada enchente, tendo lugares de composição diferentes demonstrados nos tipos de vegetação existente. Sternberg (1998, p.58), no estudo que fez no Careiro da Várzea, apresenta o seguinte aspecto resultado da enchente e vazante no Solimões - Amazonas, podendo ser percebido em toda extensão da várzea:

A deposição anual de sedimentos ricos em substâncias nutritivas representa uma vantagem incontestável, do ponto de vista agrícola. As terras mais elevadas que, só de raro, são beneficiadas, ao cabo de algum tempo se tornam cansadas. Nem todos os depósitos, entretanto, são constituídos de sedimentos capazes de fornecer uma boa base para a lavoura e a pecuária.

É que o fenômeno da turbulência, variando de intensidade, realiza muitas vezes um trabalho que se pode chamar de "triagem". Depositam-se, às vezes, em tratos contíguos, materiais bastantes diferentes quanto a granulometria e mesmo quanto a composição química. Explica-se, assim, que na várzea o solum crudum, suporte da vegetação, apresente variações espaciais consideráveis. (aspas e grifo do autor) 


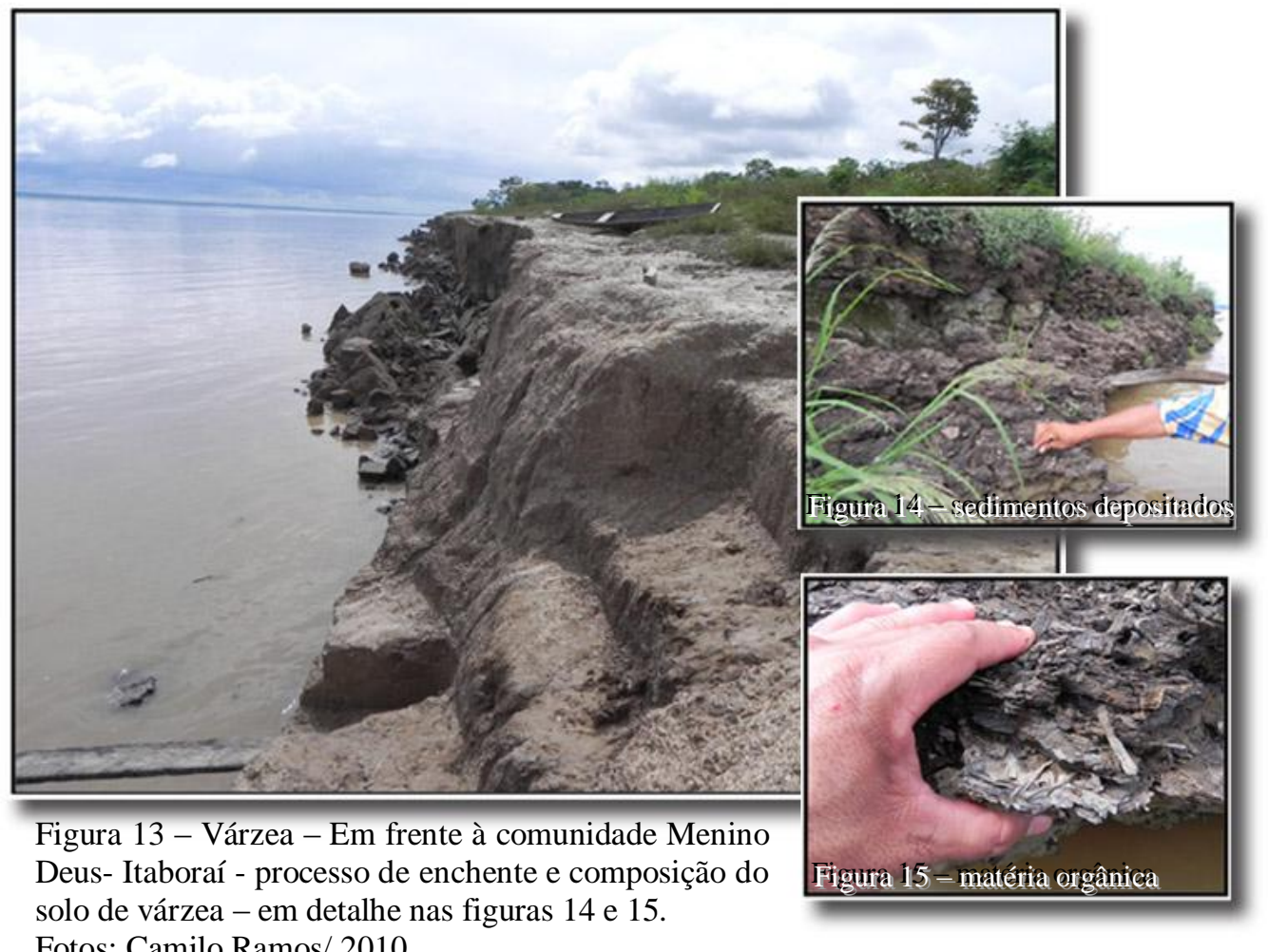

Fotos: Camilo Ramos/ 2010

A dinâmica da enchente e vazante do rio Amazonas tem um componente singular e positivo ao ribeirinho com relação à deposição de sedimentos: faz a "terra crescer" entre 20 e $30 \mathrm{~cm}$ por enchente, ou seja, a cada ano. Observador deste quadro natural, o ribeirinho sabe aproveitar bem a fertilidade do solo para realizar sua produção agrícola e utilizar também a pastagem natural para alimentar seus animais.

Outro ponto importante a destacar é a terra-caída estabelecendo o ritmo de crescimento ou redução dos terrenos. Onde a pressão hidráulica é mais intensa, haverá maior erosão fluvial e consequentemente haverá um lugar de deposição sedimentar, formando as "praias". Dialogando com o ribeirinho da comunidade do Itaboraí do Meio, onde se encontra a Escola Tiradentes, sobre o tipo de matéria orgânica que compõe a várzea, principalmente a faixa de maior concentração desse material decomposto, ele falou, que "o terreno ia até quase no meio do rio, foi reduzida pela terra-caída, que se aproximou muito do aningal ${ }^{9}$. E quando veio à cheia, o aningal acabou morrendo e foi enterrado com a quantidade de lama trazida pela enchente. A cada ano que passa mais lama é deixada após a enchente e o mato vai ficando embaixo da terra e forma essa camada escura". O ribeirinho sabe que este tipo de

\footnotetext{
${ }^{9}$ Aningal é uma vegetação aquática que possui um trançado de raízes que formam uma espécie de tapete e tendo bastante nutriente, formando uma pequena floresta aquática. Geralmente fica nos lagos.
} 
vegetação concentra vários tipos de animais e peixes, mas na crendice diz que é onde se esconde a cobra grande. Isto evidencia o saber acumulado a partir das observações feitas diariamente e depois processadas e colocadas em prática na sua forma de uso da várzea.

Várzea e terra firme não são apenas elementos físicos naturais. Para o ribeirinho é parte integrante de sua vida por se sentir integrado pela utilização de todos os recursos ofertados e extraídos da produção agrícola ou por tudo que é possível fazer para obter em benefício próprio, da família e da comunidade.

Nesses dois geossistemas estão registradas a forma de vida do ribeirinho da água e da terra e floresta com um profundo significado social, fixador de suas raízes socioculturais e criador de simbolismo cultural, quando fala: vaja, vázia, vázea, varja, mas nunca diz: várzea. Esta expressão demonstra o quanto compreende do lugar de vida, porque não é o nome que tem significado, mas a forma de construção do viver em constante movimento de aprender com a "vaja, varja, vázia e vázea" - é uma renovação a cada enchente. Nesse sentido, Dardel (2011, p.8) encaminha reflexões sobre o espaço geográfico e como este é visto ou trabalhado, sentido ou percebido, móvel ou invisível, silencioso ou falante, realidade oprimente ou excludente:

\footnotetext{
Esse espaço material não é, de forma alguma, uma "coisa" indiferente, fechado sobre ele mesmo, de que se dispõe ou que se pode descartar. É sempre uma matéria que acolhe ou ameaça a liberdade humana. Uma região montanhosa não é, antes de tudo, uma região que obstrui a circulação dos homens? A planície só é "vasta", a montanha só é "alta", a partir da escala humana, à medida de seus desígnios. A floresta é experimentada como "espessa", a Amazônia sentida como "quente", antes que essas qualidades sejam conceituadas em noções aprendidas. A despeito dessa referência a um projeto ou a uma experiência vivida, esses conceitos de amplidão, de altura, de espessura ou de calor não têm sentido. Antropocentrismo, dirão! Mas é necessário tomar partido: fora de uma presença humana atual ou imaginada, não há nem mesmo a geografia física, somente uma ciência vã. O Antropocentrismo não é uma imperfeição, mas uma exigência inelutável.

Porém, se a realidade só é geográfica para o homem, o que significa este "para"? Naturalmente, "para o homem" pode tomar frequentemente este valor claro de utensílios e significar "de interesse" ou "para o uso do" homem. Inclui-se, nesse caso, a Terra como campo de cultivo ou material de construção, o rio para a navegação, o céu para a aviação. A geografia pode ser "econômica"; mesmo o estudo do relevo ou do clima contém a preocupação subjacente do uso e da produção.
}

Esta reflexão de Dardel é importante para aprofundar a compreensão do ribeirinho, $d a$ água ou da terra e floresta, por entender e dar sentido ao espaço físico, espaço este que trabalha produzindo seu alimento e para a comercialização, não que possua conhecimento científico, mas por sua larga experiência e por saber a importância da várzea e da terra firme para sua vida, numa relação de interdependência e não de determinismo. 
O ribeirinho em sua infinita sabedoria procura manter-se um guardião do seu lugar de vida e tem sua complementaridade nas relações estabelecidas a partir do sistema de produção agrícola e pecuária nos terrenos aluvionais, como também nos solos terciários, por compreender como um aprendiz naturalizante e ensinando a humanizar o lugar quando utiliza os recursos naturais ofertados com racionalidade. 


\section{CAPÍtulo 3 - ESCOLA DA ÁGUA, DA TERRA E FLORESTA EM PARINTINS.}

A escola da água (várzea), da terra e floresta (terra firme) possuem características diferentes em sua forma de construção de conhecimentos. A primeira passou por experiências de ensinar: ensino seriado, ensino multisseriado, ensino modular multisseriado e seriado modular. A segunda sempre teve ensino seriado. Porém, as duas seguem a mesma proposta enviada pela Secretaria de Educação de Parintins, apresentando uma visão de homogeneização, quando não discute a construção da proposta de conteúdo para que seja realmente um currículo participativo e integrador.

Para se chegar ao aspecto participativo do ato de ensinar e de construir propostas curriculares olhando a realidade local, interligada com a realidade regional, nacional e global, deve haver o rompimento das amarras herdadas do processo colonizador e provinciano, vencendo o olhar unilateral do urbano sobre as realidades ribeirinhas amazônicas e, para tanto, tem que seguir os ensinamentos de Paulo Freire (1996), porque consegue traduzir o ato de ensinar, o respeito aos saberes dos educandos, a criticidade para ler e discutir a realidade, a estética e ética, o risco, aceitação do novo e rejeição a qualquer forma de discriminação. A reflexão crítica sobre a prática, o reconhecimento e assunção da identidade cultural são elementos na condução da aprendizagem.

Além desses aspectos apresentados por Freire, deve considerar o empenho, o compromisso e a responsabilidade do professor na condução de construção de conhecimentos, respeitando suas limitações. Caso contrário, o professor será apenas um mero repassador do que foi pensado distante de sua realidade, sem ter participado do processo de discussão, mas tendo que aplicar sem alterar o proposto em termos de conteúdo. Relação sempre de centro para periferia. Quando se tem liberdade do fazer, constrói-se mudanças e isso pode ocorrer quando o compromisso educativo é assumido em sua plenitude pelo professor.

A vivência junto a educadores do Amazonas proporcionou percepção e reflexão sobre as necessidades de pensar um ensino diferenciado para as escolas ribeirinhas e como estudante e professor de geografia podem construir diálogo para o ensino de geografia, tendo como elemento fundante, a Geografia existente nas comunidades ribeirinhas, pela vivência e com as propostas e alternativas apresentadas pelo Instituto de Educação Rural do Amazonas, órgão já extinto. 
Os dados aqui registrados são oriundos de toda experiência e vivência na Secretaria Municipal de Educação do município de Parintins, início da década de 1980. Oportunidade que teve de contato e trabalho com o Projeto de Educação para o Meio Rural do Amazonas, do Instituto de Educação do Amazonas. Esta vivência permitiu vislumbrar a implantação de uma proposta diferente e com múltiplas possibilidades de valorizar a escola ribeirinha que estava integrada ao trabalho do ribeirinho da várzea e da terra firme.

O projeto-piloto foi iniciado em Parintins, tendo em Manaus o órgão gerenciador Instituto de Educação Rural do Amazonas - IER-AM, ligado à Secretaria de Estado de Educação e Cultura - SEDUC. Este órgão tinha um corpo técnico que fazia o acompanhamento sistemático de toda atividade educacional e também desenvolvia pesquisa dialogada com os professores das escolas ribeirinhas para implantar as propostas mais adequadas possíveis, no sentido de equacionar os problemas da escola multisseriada, considerando que o professor possuía apenas até a $4^{\mathrm{a}}$ série.

Este Instituto promovia, em parceria com a Secretaria de Educação do Município, cursos niveladores, em nível de fundamental (de $5^{\mathrm{a}}$ a $8^{\mathrm{a}}$ série - hoje, $6^{\circ}$ ao $9^{\circ}$ ano), mas tendo na sua proposta curricular: filosofia, sociologia, antropologia, geografia, história, biologia, matemática, física, química, língua portuguesa, como também todas as disciplinas pedagógicas e didáticas. O projeto tinha como finalidade preparar o professor "leigo" para ministrar aula com uma sólida base teórica para alunos de $1^{\mathrm{a}}$ a $4^{\mathrm{a}}$ série (hoje, $1^{\mathrm{o}}$ ao $5^{\mathrm{o}}$ ano). Ao observar esta estrutura do curso, o professor era preparado para trabalhar com classe multisseriada, mesmo porque a multissérie ou o multiconteúdo estava na base teórica de formação do professor.

O professor, não possuía o conhecimento vertical das disciplinas estudadas, passava a construir, a partir do curso, uma boa base teórica para trabalhar os conteúdos de $1^{\mathrm{a}}$ a $4^{\mathrm{a}}$ série (hoje, $1^{\circ}$ ao $5^{\circ}$ ano). No curso eram trabalhadas estratégias para ensinar em classe multisseriada, concebendo os arranjos pedagógicos e didáticos para ter sucesso no processo ensino aprendizagem. Sabendo que isso não era o ideal, porém representava um avanço na Educação no Amazonas e no município de Parintins.

Outro aspecto importante era a condução do trabalho do Instituto que se fazia presente nas comunidades, discutindo, dialogando, fazendo visita técnica e realizando pesquisa participativa, tendo o produto não como um fim, mas como um processo contínuo de construção, porque o professor da escola tinha que manusear e ter o domínio da realidade ribeirinha, colaborar nas reformulações e ajustes para o aperfeiçoamento da proposta 
Educação para o Meio Rural do Amazonas, no sentido da valorização regional dos aspectos particulares e singulares, sem, contudo, perder o contato com os aspectos nacionais e globais. Isto não se traduz em perfeição em termos de proposta mas a sua diferença na condução de entender e construir uma proposta curricular que atendesse as especificidades do interior do Amazonas, incorporando toda atividade primária do pai do estudante ao conteúdo a ser estudado na sala de aula. Proposta construída com a participação do professor da escola ribeirinha. No final da década de 1980, todo trabalho que vinha sendo executado foi alterado e o Instituto foi fechado, dando espaço à novas políticas governamentais de educação e as escolas voltaram às antigas práticas educacionais.

As Secretarias Municipais de Educação do Estado do Amazonas deveriam possuir um corpo técnico de pesquisadores para fazer um acompanhamento sistemático, reunindo e discutindo com os professores os conteúdos, os procedimentos metodológicos, a didática para ter uma escola diferente, com currículo diferente, onde envolvesse todo conhecimento historicamente construído e aprendido pelos estudantes, associado ao conhecimento formal da sala de aula. Neste sentido, o professor sairia do papel de repassador de conteúdo pronto e acabado para assumir e ser o professor, pesquisador, educador e construtor de conhecimento, em conjunto com os estudantes ribeirinhos. Mudanças são necessárias, sem perder o contato com que já foi construído, porque, segundo Paulo Freire (1996, p.35)

É próprio do pensar certo a disponibilidade ao risco, a aceitação do novo que não pode ser negado ou acolhido só porque é novo, assim como o critério de recusa ao velho não é apenas cronológico. $\mathrm{O}$ velho que preserva sua validade ou que encarna uma tradição ou marca uma presença no tempo continua novo.

Então, fazer ou implantar novas ideias tem que estar alicerçadas nas velhas e boas ideias para se construir uma proposta solidificada de ensino para as comunidades ribeirinhas amazônicas, onde todos possam ser agentes participativos e construtores. Dessa forma, a procura do certo passa a existir com a ação coletiva de construir propostas significativas para a escola ribeirinha amazônica e não mais a imposição do que está pronto. Pode ser utópico, mas há necessidade de fazer algo e urgente.

O que se propõe são estudos urgentes sobre as práticas educativas em espaços formais e não-formais, no sentido de pensar e construir coletivamente propostas estimuladoras de ensino e aprendizagem para as escolas da Amazônia, no sentido de atentar para interação inter e transcultural, seguindo os ensinamentos de Moacir Gadotti (2009, p.15): 


\begin{abstract}
A Pedagogia intertranscultural tem olhar ecossistêmico e analisa as atividades interdisciplinares - que aproximam as diferentes disciplinas com base em projetos comuns - e transdisciplinares - que permitem o reconhecimento de pontos de contato e semelhanças entre as diferentes disciplinas -, que são organizadas num currículo intertranscultural que, por sua vez, contribui para a ação educativa integral. Entenda-se que este currículo intertranscultural procura incorporar o conhecimento científico, mas, ao mesmo tempo, busca transcendê-lo - o que não significa superá-lo nem substituí-lo, dando ênfase à cultura como referencia primeira na relação com outras formas e manifestações do conhecimento e da sensibilidade humana. (grifo do autor).
\end{abstract}

A questão é: será que as Secretarias Municipais de Educação estariam preparadas para assumir a construção de um currículo intertranscultural? Assumir um currículo intertranscultural é dar autonomia no fazer ensino aprendizagem para a escola, porque haveria uma complementariedade no ato educativo - que seriam o sociocultural, o socioambiental e o socioeconômico, considerando e envolvendo o saber historicamente construído, fortalecendo as práticas cotidianas num todo, porque a aprendizagem se daria de forma conjunta tanto professor quanto estudantes, lendo e relendo o mundo existente a partir da realidade vivida. Assim, estaria construindo uma escola-cidadã e democrática compromissada na construção de cidadãos e cidadãs livres e autônomos, segundo Oliveira, Inês (2003, p. 17)

\begin{abstract}
A questão que se coloca é, portanto, compreender que mecanismos de aprendizagem, individuais e coletivos, têm produzido as formas de inclusão social, subalternas ou não, dos sujeitos e grupos sociais nos diversos espaços estruturais da sociedade, para pensarmos possíveis modos de intervenção sobre esses processos, de modo que eles possam, cada vez mais e novamente, contribuir para a emancipação social, tanto dos sujeitos quanto dos grupos.
\end{abstract}

Dentro deste contexto educativo e do processo de emancipação social proposto por Oliveira, Inês (2003) a Geografia seguiria de acordo com a figura 16, no sentido de mostrar como as categorias elegidas se comunicam e se inter-relacionam, tendo sempre como base ou eixo a cultura. Isto é apenas uma proposta para o início de discussão de construção curricular de Geografia para a escola da água, terra e floresta, que estaria compondo a estrutura curricular intertranscultural, como propõe Gadotti, contribuindo para inserção dos conhecimentos tradicionais ao currículo. Importante salientar que não há proposta curricular ideal, mas tenta-se abrir comunicações para propostas alternativas que permitam um ensino mais significativo. 


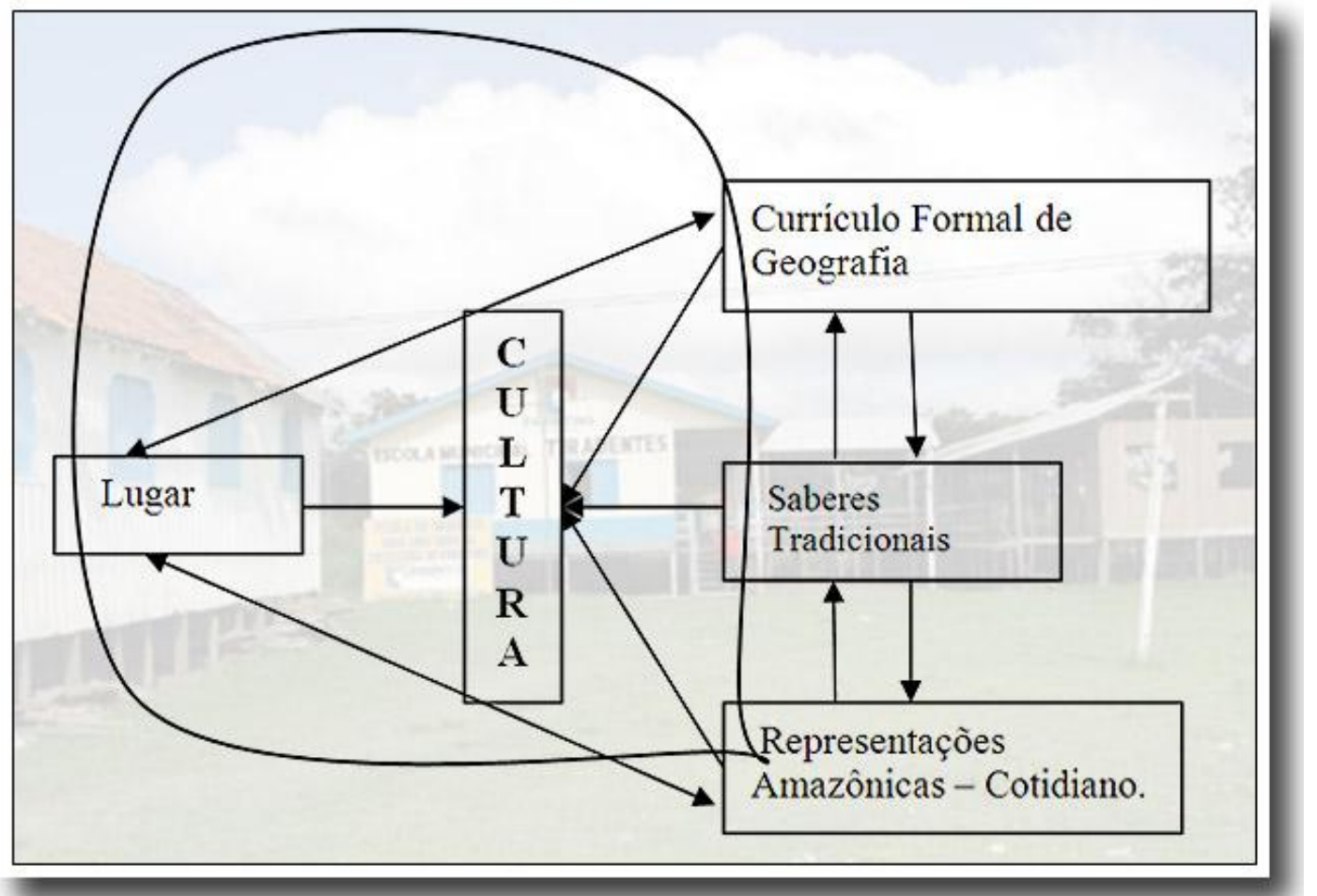

Figura 16 - Esquema para pensar o ensino de Geografia Organizado por Camilo Ramos

Fica evidente o processo sistêmico existente na Amazônia e sua forma articulada de manter comunicação e complementação entre si. É importante ressaltar que o processo sistêmico não é só na Amazônia que existe, sendo que o enfoque dado é porque se procurou entender e representar à complexidade da própria Amazônia, na particularidade dos dois lugares da pesquisa - comunidade de Santa Maria - Vila Amazônia e Menino Deus - Itaboraí do Meio, pertencentes ao município de Parintins. Por isso, este esquema coloca a cultura ${ }^{10}$ como eixo principal para compreender e extinguir o fosso entre o currículo de Geografia e os saberes tradicionais. Demonstra também como esses elementos se interligam e se comunicam na construção de saberes cotidianos no sentido da fusão em saber cientifico, possibilitando a construção de conhecimentos pelos estudantes a partir da realidade vivida. Assim, os elementos propostos direcionam a forma de ver e trabalhar a Geografia nesse imenso

\footnotetext{
${ }^{10}$ Cultura está baseada nas proposições de Zeny Rosendahl e Roberto Lobato Corrêa (2005), quando apresentam e discutem Geografia: temas sobre cultura e espaço, na perspectiva das inúmeras paisagens culturais centrada na geografia cultural, envolvendo aspectos ligados a monumentos e seus significantes, as festas e suas representações e todas as relações socioeconômicas, sociopolíticas e as diversas dimensões socioambientais existentes e praticadas no lugar.

Esta discussão da geografia cultural conduz a uma leitura sobre o que está construído em cada comunidade e que pode compor a proposta curricular adotada nas escolas, como pode ser base de conteúdo a ser estudado.
} 
laboratório de produção de conhecimento que é a Amazônia, a partir dos seus recursos naturais e culturais.

É preciso pensar e discutir escola e currículo como processo educativo diferenciado a ser construído e praticado em Parintins e Amazônia para que se possa usufruir dos recursos naturais que existem nos lugares amazônicos, utilizando-os didaticamente para ensinar e aprender Geografia na sala de aula e na prática cotidiana, de forma que os estudantes possam sempre ressignificar o aprendido e colocar em prática nas atividades diárias.

\subsection{Escola, currículo e ensino de Geografia}

A compreensão de escola como espaço de relações de produção de conhecimentos e de relações socioculturais, evidencia as múltiplas realidades existentes nas comunidades ribeirinhas e que estão inseridas no interior de cada sala de aula como forças estabelecidas pelos saberes, as quais se tornam elo de comunicação e discussão transformando em novos saberes para a leitura e entendimento do lugar, conforme expressa Cavalcanti (2012) a escola é um lugar de cultura e por isso envolve as representações sociais, econômicas, culturais e ambientais, como processo sistêmico contínuo, registrando a tensão de encontro e confronto na construção de conhecimento, resultado do processo histórico.

Estas representações se fazem presentes nas escolas das comunidades ribeirinhas do município de Parintins, expressas nas atividades diárias, seja no caminho da escola, nas remadas até o lugar para pescar o alimento, no momento do banho na beira do rio, seja nas conversas corriqueiras da família ou até nas histórias contadas pelos pais sobre suas aventuras em caçadas ou pescarias e nas representações das lendas e mitos.

Estes conhecimentos tradicionais poderiam ser a mola propulsora para se construir uma escola diferente com alunos diferentes, pois o conhecimento estaria sendo construído a partir das leituras cotidianas feitas pelos estudantes. Assim,

A escola tem a função de "trazer" o cotidiano para seu interior com o intuito de fazer reflexão sobre ele a partir de uma confrontação com o conhecimento científico. Nesse sentido, deve estar estreitamente ligada ao cotidiano. Porém, se a prática cotidiana é uma referência da escola, é no sentido de contribuir para sua reflexão e transformação e para tanto tem como instrumentos os conhecimentos científicos que veicula. A prática cotidiana, interpretando o depoimento da professora, está em busca do imediato, daquilo que pode causar aparentemente conforto e bem-estar imediato. Ela está chamando a atenção para o fato de que muitas vezes a busca do bem-estar imediato, sem que nela haja uma reflexão, pode levar até mesmo a impedir a realização desse próprio bem-estar. Um caminho para provocar mudanças na prática cotidiana, que tem uma espacialidade, pode ser o 
sugerido pela professora: o de trazer para a sala de aula essa prática e de problematizá-la. A partir daí, como poderia ser feito a professora, o caminho poderia ser o de dar elementos que auxiliassem o avanço na compreensão do problema. (CAVALCANTI, 1998, p. 129 - aspas da autora).

Estes elementos, apontados por Cavalcanti, são importantes na construção de um currículo significativo para a escola ribeirinha porque teria como alicerce ou como eixo de atração à representação sociocultural, os saberes tradicionais, o próprio currículo, tendo como base a categoria geográfica lugar e o eixo cultura, por expressar as relações cotidianas.

$\mathrm{Na}$ perspectiva da compreensão do currículo é importante discorrer sobre a sua construção histórica e processual. A palavra curriculum, de origem latina, tem como significado o curso, a rota, o caminho da vida ou das atividades de uma pessoa ou grupo de pessoas, mantendo relações estratégicas de interesses e dominação. O currículo educacional representa a síntese dos conhecimentos e valores que caracterizam um processo social expresso pelo trabalho pedagógico desenvolvido nas escolas. Assim, o currículo é definido como um percurso a ser seguido e como conteúdo apresentado para estudo, por manter e estabelecer relações de aprendizagem dentro da lógica ou estrutura de poder, de acordo com que preconizou Goodson (1995).

Os primeiros estudos no campo do currículo, de origem norte-americana, foram influenciados pelo modelo tecnicista de natureza prescritiva, baseados nas categorias de controle e eficiência social. Destaca-se neste sentido, a obra de Ralph Tyler (1974), na qual mostra preocupação com o estabelecimento de objetivos educacionais e com a avaliação. $\mathrm{O}$ currículo era visto como uma atividade neutra, instrumento de racionalização da atividade educativa e controle do planejamento. O pensamento de Tyler influenciou os estudos sobre currículo no Brasil, adotado como fundamento teórico na organização curricular do ensino na década de 1970.

O currículo pode ser um instrumento de mudança social a partir da escola, contudo, no momento atual, exerce a função primordial de alienação por não passar por um processo de discussão e construção coletiva, mas de reprodução do que é imposto como modelo a ser seguido, como expõe Goodson (1995, p. 47)

O valor da teoria curricular precisa ser julgado em confronto com o currículo existente - definido, discutido e realizado nas escolas. Entretanto, as teorias curriculares atuais geralmente não apresentam explicações ou hipóteses sobre o que é comprobatório, o que está diante dos olhos. As teorias atuais não são curriculares, são meros programas; são utópicas, não realistas. Preocupam-se com aquilo que deveria ou poderia ser, não com a arte do possível. Atuam, não para explicar, mas para exortar. 
Seguindo esta forma de pensar o currículo, Machael Apple (2000), em Repensando Ideologia e Currículo, expõe sua crítica na relação entre dominação econômica e cultural frente ao trabalho escolar, os quais produzem e reproduzem a desigualdade social, ocultamente, consciente ou inconscientemente, no interior da escola ou nos espaços escolares. Baseado na nova sociologia da educação, procura criticar o que está sendo institucionalizado como política social e educacional, quando são estabelecidas conexões com as estruturas de desigualdade existentes na sociedade diante das tentativas de superá-las, mesmo porque

\footnotetext{
Isto implica que devemos nos assegurar de que o curso que seguimos e sobre o qual pesquisamos "dignificará a vida humana, reconhecerá os aspectos lúdicos e criativos das pessoas" e verá os outros, não como objetos a serem manipulados ou "libertados" para seguir os ditames da "mão invisível" do mercado, mas como sujeitos corresponsáveis, envolvidos no processo de deliberar democraticamente sobre os fins e os meios de todas as suas instituições. (APLLE, 1997, p.15 - aspas e grifo do autor).
}

Importante salientar que, além da teoria do currículo de abordagem sociológica, há novos pensamentos envolvendo relações cotidianas escolares na perspectiva de um currículo pleno, com o devido respeito à diversidade cultural, no sentido de estabelecer a ressignificação dos seus referenciais identitários, quando se passa a valorizar a maneira de sentir e ver o mundo, sob a ótica critica da realidade vivida (GONZAGA, 2004). Ghedin, Gonzaga e Borges (2007) propõem discussões e defendem o modelo de interpretação que concebe o currículo como fundamento construído no cruzamento de influências e campos de atividades diferenciadas e inter-relacionadas, permitindo analisar o curso de objetivação e concretização do currículo em seu processo teórico, concebendo seus vários níveis sócio e intercultural assinalados nas suas múltiplas transformações históricas.

Ao focar os processos condutores das práticas escolares como elementos dinâmicos de transformações sociais, Ghedin (2007, p. 9) faz a seguinte afirmativa:

A escola é o lugar da construção dos sentidos que adquire nossa existência, por isso ela é fundamental para todos nós. Negá-la ao ser humano é o mesmo que negar a sua existência. $\mathrm{O}$ que aprendemos na escola estrutura toda nossa existência. Por conta disso, sempre esperamos muito mais do que ela nos é capaz de dar. Isso que esperamos a mais dela é resultante, justamente, do que ela nos oferece, e do que ela deixa de oferecer. 
Estudos críticos do currículo apontam que a seleção cultural sofre determinações políticas, econômicas, sociais e culturais. Neste sentido, a seleção do conhecimento escolar não é um ato desinteressado e neutro. É resultado de lutas, conflitos, interesses e negociações. Assim, entende-se que o currículo é culturalmente determinado, historicamente situado e não pode ser desvinculado da totalidade do social, de acordo com Costa (2005) e Silva, Tadeu (2005).

Os estudos que analisam os efeitos do currículo para além da aquisição de conhecimentos formais se voltam para a concepção de currículo oculto. Os elementos ocultos estão em toda relação dentro dos espaços não formais de transmissão de saberes historicamente construídos contrapondo às transmissões de ideologias, concepções de mundo, pertencentes a determinados grupos hegemônicos na sociedade e que serve para reproduzir as desigualdades sociais. Segundo William E. Doll Jr. (1997) a visão muda após as falhas detectadas no processo produtivo social, na pós-modernidade.

É importante acrescentar o currículo oculto como resultado das atitudes, valores e comportamentos sociais que não compõem explicitamente a base curricular, mas que são ensinados através das relações socioculturais, nas festas religiosas, nos rituais, nas práticas diárias dos trabalhos comunitários e de toda relação espacial e temporal da escola. (SILVA, TADEU 2000).

A literatura crítica no campo do currículo tem argumentado a favor de uma teoria que leve em consideração a dimensão prática do currículo. Trata-se de uma perspectiva que busca compreender o currículo em ação, ou seja, os contextos de concretização do currículo desde a sua prescrição até a efetivação nas salas de aula.

No contexto prático é preciso saber olhar o entorno para compreender os aspectos histórico-espaciais, como a arte vista nos prédios escolares, assim como o jardim, a porta, parte essencial no embelezamento, dignificando a vida do estudante no processo ensinoaprendizagem e permitindo associar conteúdo formal com todas as representações de conteúdos explícitos e implícitos nas placas de inauguração, paredes, telhados, porque existem relações trabalhistas - modo e meio de produção, divisão social do trabalho e múltiplas relações socioculturais e sociopolíticas. (FRAGO E ESCOLANO, 2001).

Ainda, de acordo com a perspectiva teórica-prática do currículo, percebe-se que são ressaltados os contextos do trabalho docente com o conhecimento e com o processo ensinoaprendizagem, contexto curricular complexo e problemático. 
A discussão sobre currículo se encontra no processo de seleção e organização dos conteúdos trabalhados nas escolas, onde há a priorização dos que podem ser ou não explorados em sala de aula. Neste sentido, ao se discutir as escolhas feitas pelos professores, está se discutindo não só as opções, mas as concepções acerca de uma determinada sociedade e de como se percebe seu desenvolvimento, a partir de sua organização sócio-espacial.

Em relação ao currículo e ao ensino de Geografia, o trabalho de Cavalcanti (1998): Geografia, Escola e Construção de Conhecimentos, abre questionamentos críticos sobre o que se ensina, como se ensina e para que se ensina Geografia, onde a autora se posiciona sobre o processo de ensino-aprendizagem e a falta de domínio dos conceitos das categorias geográficas, importantes para leitura e compreensão do lugar como também da própria realidade em que os sujeitos estão envolvidos.

\footnotetext{
Ao manipular as coisas no cotidiano, os indivíduos vão construindo uma geografia e um conhecimento geográfico. Porém o pensamento e a ação que ocorrem no plano individual-particular nunca existem de forma pura, pois o comportamento genérico, que ultrapassa o imediato e se reveste do social mais amplo, está contido, em alguma medida, naquele plano. Sendo assim, a geografia produzida individualmente contém elementos de uma geografia, digamos, mais global. Em outras palavras, a produção da geografia pelo individuo depende, entre outras determinações, do conjunto de representações sociais sobre o espaço. A consciência dessa geografia produzida, individual e genericamente, provoca alterações na prática social cotidiana. O distanciamento das ações cotidianas, como fez por exemplo Marcovaldo, para refletir sobre as coisas manipuladas cotidianamente, é uma prática cotidiana necessária quando se quer elevar as ações ao nível genérico, quando se quer dar um sentido social a essas ações. [...] (CAVALCANTI, 1998, p. 123).
}

Diante do direcionamento apontado por Cavalcanti sobre a construção de conhecimento geográfico a partir das relações cotidianas, a própria eficácia do ensino de Geografia - pensando a função do currículo - percebe-se porque este foco de discussão é tão significativo. A palavra currículo apresenta e aparece com dois sentidos muito esclarecedores no meio pedagógico ou no processo ensino-aprendizagem, já apontados anteriormente: como conhecimento escolar ou como experiência de aprendizagem. Mesmo com enfoques diferentes, os dois sentidos estão presentes no currículo escolar, assim, um completa o outro.

É nesta perspectiva das relações socioeducativas e cotidianas que Rafael Straforini (2004, p. 52), em seu livro Ensinar Geografia: o desafio da totalidade-mundo nas séries iniciais, elucida o processo que conduz o estudante a ler e reler o mundo, analisando e criticando sua realidade, porque 
[...] a maneira de ver o mundo de forma fragmentada é resultado da especialização da sociedade e da ciência moderna, estimulada pela crescente necessidade de acumulação do capital, produzindo, assim, uma Educação alienante. O ensino realizado nessa perspectiva torna-se fragmentado e a escola passa a ser um elemento estranho, alienígena à realidade. Tomar consciência da realidade implica em identificar no interior da estrutura social as categorias da realidade que possam explicar as reais condições materiais da existência dos alunos no cotidiano, ou seja, um ensino preocupado com a totalidade e não com a fragmentação.

Dessa forma, percebe-se que o currículo é uma construção social, no sentido que está diretamente ligado a um momento histórico, a uma determinada sociedade e as relações que esta estabelece com o conhecimento. Partindo deste enfoque, ter-se-á nas diversas realidades uma pluralidade de objetivos com relação ao que ensinar em Geografia nas escolas ribeirinhas, no sentido de que os conteúdos propostos compõem um quadro bastante diverso e ao mesmo tempo peculiar. É importante salientar que o ensino de Geografia pode e deve ser um componente que permita ao estudante ribeirinho ler criticamente a estrutura social que o envolve, como também adquirir entendimento das dimensões escalares, por ser uma das partes do lugar de convivência deste estudante, no qual está interligado com o global e viceversa.

Desta maneira, o currículo é construído dentro de um processo histórico e por meio das múltiplas relações sociais se estrutura, não sendo possível, de uma hora para outra, deixar para trás todas as experiências passadas. Assim, ao percorrer o processo histórico do ensino no Brasil, principalmente o de Geografia, não se pode ignorar quais conteúdos eram trabalhados nos diversos momentos e como era sua organização e seleção, compreendendo como estes interferem na atual realidade. É importante salientar que o currículo deve ser construído, em tempos atuais, a partir de reflexões coletivas com todos os sujeitos envolvidos no processo ensino-aprendizagem, principalmente com o professor.

Em relação aos pontos apresentados e discutidos referente ao currículo é que Vesentini (2004) diz que não cabe mais, em pleno século XXI, o ensino da Geografia de forma tradicional, descritivo, sem contextualização com a realidade. Este ensino da Geografia deve levar o educando a compreender o mundo em que vive, e com isso entender as múltiplas relações sociopolíticas, sociocultural ou socioambiental, estabelecedoras de relações problemáticas entre a sociedade e a natureza. Ainda nesta perspectiva encontramos em Vlach (2004) todo o processo histórico do ensino da Geografia no Brasil, onde destaca a construção desta ciência, as mudanças e as críticas sofridas e como ela pode atuar de modo significativo na vida do educando no contexto da aprendizagem e da leitura de mundo. Ainda se pode perceber nesta discussão do ensino de Geografia e do próprio currículo nas palavras de 
Pontuschka (2004), quando discute o conceito de estudo do meio como uma possibilidade de transformar, em tempos e espaços diferentes, as escolas e os professores, para que se tornem agentes de mudanças significativas no ato de ensinar e aprender.

Procura-se nesta discussão encontrar alternativas atrativas e significativas do ensino de geografia para o estudante e um desses aspectos está ligado ao conteúdo. O que se ensinaria sem conteúdo? Como os estudantes se educariam e leriam sua realidade, sem conteúdo? Houve um esvaziamento de conteúdos geográficos do espaço escolar, por conta dos movimentos progressistas das últimas décadas do século $\mathrm{XX}$, que via nesse uma maneira de reproduzir cultura dominante e deixar o estudante com conhecimento cada vez mais fragmentado (STRAFORINI, 2004). Segundo Sacristán (1998) sem conteúdo não há ensino e nem aprendizagem, mas qualquer projeto educativo procura a concretização no desejo de alcançar resultados positivos nos sujeitos que se educam em processo contínuo.

Porém, é importante pensar este conteúdo geográfico para que se possa falar de sua seleção, organização e como a cultura pode ou não ser reproduzida no cotidiano escolar. Para tanto, o conteúdo nos faz percorrer diversos momentos da história, principalmente aquele tradicional, no qual era visto como algo estático e como verdade absoluta, nunca como um elemento que pode ser questionado e transformado.

Neste sentido, no livro Geografia em Perspectiva: ensino e pesquisa, organizado por Pontuschka e Oliveira, Ariovaldo (2002), encontram-se discussões a cerca do ensino, de propostas metodológicas e da formação do professor de geografia. Apresenta vários caminhos para a melhoria do processo ensino-aprendizagem, onde os conteúdos passam ter significado na vida dos educandos e, ao mesmo tempo, ser entendidos como um processo de construção social, para que seja dinâmico e não estático. É, portanto, o conteúdo geográfico, um elemento de transformação da sociedade e poderia agir na escola das comunidades ribeirinhas de Parintins como um alicerce na construção de cidadãos críticos e cientes de seus direitos, fortalecendo o sentimento de identidade de cada estudante ribeirinho. O ensino de Geografia pode ser, nessa perspectiva, o elo de ligação entre os saberes tradicionais e os saberes formais, por abrir caminhos para trabalhar a leitura e compreensão de lugar, em que é expressa a cultura dos sujeitos do processo educativo.

Assim, é possível compreender que os conteúdos não são sempre os mesmos e, historicamente, estes são transformados mediante a realidade da sociedade em que se está vivendo. A escola assume função social diferente, refletindo desta maneira um olhar acerca do conhecimento e de cultura diferenciada. O processo de seleção e organização dos conteúdos é 
por si um elemento de escolha e decisão, e estas ações não são neutras, pois elas regulam e distribuem o que se ensina, por decisões do sistema socioeducativo e político, ficando estabelecido uma relação de poder (SACRISTÁN, 1998).

O processo de seleção do que ensinar é, de certa maneira, a questão central dos conflitos que permeiam as ações educativas, nas quais se apresentam como lutas e negociações. O que se ensina são decisões sem discussão coletiva e impostas como parte fundamental na formação de quem se encontra em processo de estruturação intelectual.

Estes processos de seleção envolvem um comprometimento político que visam garantir a hegemonia de determinados saberes. Desta maneira, perpetuam-se visões de mundo por meio da cultura. Vale ressaltar que cultura passa a ser o eixo central para se entender o fosso que há entre o currículo de Geografia e os saberes tradicionais.

Sobre a organização, numa abordagem tradicional, está em questão o tipo de conhecimento e a sequência em que pode e para quem pode ser ensinado. Para tal, leva-se em consideração a estrutura lógica da disciplina e o nível de desenvolvimento cognitivo do aprendiz. Neste sentido, todo conhecimento possui uma lógica e que, só traduzindo numa linguagem mais simples, pode ser acessível ao aluno. Diante desta lógica tradicional, para uma visão avançada do ensino, tem que se considerar os matizes e as representações sociais e culturais do lugar, processados dentro da escola como parte do conteúdo ou conhecimento escolar.

Discute-se, em função disto, como o conhecimento se torna um conteúdo escolar, pensando os mecanismos através dos quais a escola não apenas transmite saberes, mas também os produz (SANTOS e MOREIRA, 1996). Parece que o conhecimento discutido na escola é diferente ou tem função diferenciada daquele utilizado, estruturado e aplicado no cotidiano de todos os sujeitos da sociedade, sejam estudantes ou não. É presente na escola a ideia de que é preciso um conteúdo antes do outro, sendo este de maneira crescente. Assim o saber da sociedade é diferente do saber escolar e ambos são recontextualizados.

Todo o processo de ensino é delicado para ser pensado de maneira tão ampla, visto que, cada realidade tem suas características particulares, porém nenhuma está isenta das relações que engendram a sociedade no que tange às lutas sociais nos mais diversos níveis. Neste sentido, falar das escolhas dos professores, por meio dos processos de seleção e organização curricular é buscar compreender um pouco desses caminhos por onde passam suas experiências e como estas manifestam a realidade em que estão inseridas, até ressignificando o que aprenderam ou o que ensinam, seja na cidade ou nas escolas ribeirinhas. 
As escolhas dos educadores são baseadas em suas experiências como alunos e profissionais no desempenho de sua função, como também no universo em que historicamente e socialmente estão inseridos. Pensando assim, segundo Oliveira, Inês (2003) a realidade do dia-a-dia nunca é repetida apesar de serem realizadas quase da mesma forma. Ainda, seguindo os ensinamentos da autora, o que se aprendeu historicamente é fruto de um ensino repressor que não permitia discutir, apenas absorver o ensinado, até porque o importante era o fazer, já que podia ser medido, quantificado, regulamentado e controlado, e não o como fazer, que varia de um simples questionamento à liberdade de pensar analiticamente o ensinado, em Geografia.

Neste sentido, ao se pensar em valores tidos como desejáveis, os educadores trabalham a partir do que acreditam ser importante para seus alunos aprenderem e experimentarem. Assim, baseados em suas próprias experiências, os educadores envolvem seus alunos no que para ele é tido como significativo para compor as aprendizagens na escola, mas ainda não se observa abertura de discussão coletiva sobre o que está sendo ensinado e porque está sendo ensinado determinado conteúdo em geografia.

O olhar para estes elementos tidos como pessoais e geográficos podem até, de certa maneira, representar para o estudante como se eles dependessem unicamente do professor. Alguns deles até dependem, porém este profissional não está inserido em um espaço neutro, isento de lutas e disputas, pois ele utiliza o currículo, que é uma prática social. Neste sentido, o currículo, como uma prática social, é um elemento produzido e produtor de identidades. Cavalcanti (2005, p.199 - 200) enriquece a discussão quando faz a seguinte afirmativa:

\begin{abstract}
De acordo com essa concepção, os professores, ao ensinarem geografia, devem ter em mente que essa disciplina se constituiu na história da formação escolar congregando basicamente conhecimentos de uma área científica que pretende ser uma perspectiva de análise da realidade, que é a geográfica. Para tanto, essa área tem constituído um conjunto de conceitos, categorias e teorias, a partir dos quais constrói seu discurso. Pode-se chamar esse discurso de linguagem geográfica. Pois bem, para que o aluno aprenda geografia, não no sentido de assimilar as informações geográficas mas de formar um pensamento que lhe permita analisar a realidade na perspectiva geográfica, é preciso que ele trabalhe com essa linguagem. A aprendizagem geográfica requer, nessa perspectiva, a formação de conceitos geográficos, ainda que não se considere essa formação suficiente. E, sendo assim, o ensino deve se voltar para a apropriação de significados geográficos, processo que ocorre na negociação de significados resultante da relação dialógica.
\end{abstract}

Assim, procura-se relacionar a identidade como um fenômeno produzido e não acabado dentro das práticas sociais tidas como comuns em um determinado grupo social, em um determinado lugar. Para pensar na possibilidade de uma identidade no e do espaço escolar, 
parte-se do princípio de que as pessoas na escola constroem ideias e representações acerca das disciplinas e neste caso da geografia e dos rituais que compõe este universo.

\begin{abstract}
Do ponto de vista da geografia, esta é a perspectiva para se estudar o espaço: olhando em volta, percebendo o que existe, sabendo analisar as paisagens como o momento instantâneo de uma história que vai acontecendo. Essa é a leitura do mundo da vida, mas que não se esgota metodologicamente nas características de uma geografia viva e atual, assentada em categorias de análise que supõem a história em si, o movimento dos grupos sociais e a sua interligação por meio da ação ou até de interesse envolvidos. Há que se pensar também no paradigma de educação capaz de acolher, ou de referenciar, esse tipo de análise. [...]. (CALLAI, 2005, p. 235).
\end{abstract}

Os aspectos geográficos apontados por Callai são relevantes para pensar na identidade cultural a partir do ensino de geografia dentro da realidade escolar, mas é preciso se remeter às diversas realidades curriculares presentes nas escolas ribeirinhas, algumas visíveis e outras não tão visíveis ou invisíveis. Portanto, este é um elemento inserido num currículo escolar que está em constante transformação e dentro de uma lógica sistêmica, em uma guerra de forças diante das quais os sujeitos nem sempre percebem este movimento ligado às relações estabelecidas de poder dentro e fora da escola.

Nesta discussão envolvendo escola, currículo e ensino de geografia, foram evidenciados os conjuntos de fatos e conhecimentos existentes e acumulados pelas sociedades para serem transmitidos aos estudantes, que despertam preocupações e exigem esforço para as possíveis mudanças. Para que isto aconteça, tem que se pensar a construção de uma escola como um lugar dinâmico e o conhecimento como um elemento mutável. Neste sentido, a escola, o conhecimento e a cultura deixam de ser estáticos e passam a receber influências dos diversos aspectos políticos, sociais, econômicos, entre outros, que estão na sociedade brasileira, refletidas nas comunidades ribeirinhas amazônicas.

Os estudos acerca de currículo e ensino de geografia, na perspectiva cultural, apontam para discussões que proporcionam vislumbrar a compreensão das relações entre a cultura, o conhecimento e o poder no espaço escolar, a partir dos elementos culturais da comunidade ribeirinha ou sociedade em geral.

Ressalta-se que a escola ribeirinha é um lugar de relações e estudos culturais, compondo-se em um campo que compreende a cultura como prática de significação, centrada na linguagem e no discurso da constituição sociocultural. Desta forma, projeta-se a partir da escola a memória dos sujeitos construtores de seu espaço de sociabilidade, refletindo o processo coletivo de socialização da aprendizagem, porque segundo Meinerz (2006, p. 204) "a memória coletiva é o quadro de referência social e cultural para entender o grupo e o 
indivíduo. Ela diz respeito às tradições presentes no grupo, como parte de uma sociedade, enquanto a memória histórica diz respeito à valorização, elaboração e compilação de determinados fatos". Então, as atividades grupais ou individuais de aprendizagem são relações significativas que se dão no interior das práticas sociais estruturadas e que na escola se constituem em campos de saber, em que os elementos ativos no processo escolar - os professores, estudantes, pais de alunos, comunitários e estruturas educacionais - definem como importantes para compor os tempos e espaços escolares. Neste sentido, alguns conhecimentos são tidos como o mais legítimos, como conhecimento oficial. Este ponto torna-se fragilizado por não se apoderar do saber tradicional como elemento importante de construção de conhecimento geográfico existente na comunidade, mas distante da sala de aula.

Desse modo, para determinado grupo e pelas imposições sistêmicas, o conteúdo ou o conhecimento oficial centrado nas determinações curriculares, é tido como o "ideal" a ser trabalhado no espaço escolar, sendo que o conhecimento tradicional, construído nas relações pretéritas e atuais, dificilmente chegará à escola, tornando-se invisível ao processo de ensino e aprendizagem.

Assim, a educação, o currículo e o ensino de geografia são vistos como campos de conflito em torno de duas dimensões centrais da cultura: o conhecimento e a identidade. A primeira dimensão, devido ao predomínio de princípios pré-estabelecidos de uma minoria que controla os diferentes segmentos econômicos da sociedade, acaba adjetivando-se como superior, fazendo prevalecer à identidade legitimadora (CASTELLS, 2002); sua dimensão, que é continuamente retroalimentada nas simples e complexas relações nos diferentes grupos e instituições, inclusive na escola, independente do contexto em que aquela esteja inserida. A segunda se constrói como processo estruturante da relação social e firmada no contexto de pertencimento dentro do lugar de vida.

Para encerrar esta discussão teórica e para deixar registrado todo e qualquer elemento seja de representação, saberes tradicionais, currículo de geografia, lugar ou do eixo de atração, a cultura, ter-se-á a cartografia escolar, não só como conteúdo, mas como processo dinamizador das representações geográficas das comunidades ribeirinhas. A cartografia escolar permitirá ao estudante da escola de várzea ou de terra firme representar a sua comunidade e a sua escola, tendo como suporte o que aprendeu, tanto com seus pais quanto com seus professores, podendo demonstrar os elementos físicos como também o espaço socialmente organizado. 
O uso das representações cartográficas ajudará o estudante a compreender o viver e o morar, porque poderá alterar a forma de olhar o seu lugar de vida, passando a ler e reler a sua realidade, vendo e se apoderando da geografia existente na sua comunidade ribeirinha.

Outro elemento importante da cartografia a ser utilizada pelos estudantes na escola e no seu processo de aprendizagem, é o mapa mental por permitir a demonstração da sua relação com o lago, com o trabalho familiar de produção e até mesmo porque, através da percepção, poderá ter a compreensão do processo de ensino-aprendizagem da geografia (currículo de geografia) e do fortalecimento de sua identidade cultural (saberes tradicionais). Porque tudo faz parte do currículo em construção na Amazônia, não como elemento estático, mas como processo dinâmico de comunicação, alicerçado nos saberes tradicionais e sistematizados.

O saber sistematizado está na escola que exercita o fazer cartográfico nas representações gráficas das crianças, retratando o seu dia-a-dia familiar e o que aprendeu nas pescarias ou caminhadas pela margem do rio e florestas ciliares.

Logo, os mapas e os desenhos são relevantes no resgate e na valorização da identidade cultural das populações ribeirinhas, assim como os espaços vividos e percebidos pelas crianças. Além do mais, a geografia escolar passará a ter um novo sentido de vida dos estudantes. Mesmo porque se sentem na condição de ressignificar o que estudam, como estudam e porque estudam, contextualizando com a realidade vivida. O lugar do morar e do viver passa a ser representado, dando sentido e significado no processo da aprendizagem, porque passa a ter utilidade e aplicação prática.

A realidade geográfica passará a ser registrada tanto no sentido do ribeirinho quanto do urbano, em destaque os aspectos sociais, culturais e econômicos, assim como a dinâmica climática, a hidrográfica e demais aspectos físicos da comunidade, base dos ensinamentos dos mais velhos para as crianças. A representação gráfica ou cartográfica nas escolas das comunidades ribeirinhas do município de Parintins partiria do vivido para o experienciado.

Dessa forma, os resultados poderão ser significativos, motivadores, na medida em que registram e incorporam a representação cotidiana do lugar onde a experiência e os ensinamentos dos saberes escolar e tradicional estão contidos nas expressões cartográficas dos estudantes das comunidades ribeirinhas de Parintins, podendo ser dimensionado para o Amazonas ou Amazônia.

Então, quando o ensino escolar de geografia estiver mais estruturado nas escolas ribeirinhas - não como reprodutor do conhecimento já construído, mas como possibilitador de 
construção de novos conhecimentos a partir do aprendido - poderá ser o meio de representar e articular os conhecimentos e, para tanto, há necessidade de ter domínio sobre a escala, pois é um elemento fundamental de leitura da realidade.

A escala de análise poderá ser utilizada pelo estudante ribeirinho nos seus estudos, permitindo fazer uma leitura do fenômeno em uma dimensão regional a partir de dados e análises locais, sendo possível fazer um quadro comparativo, ou seja, o estudante terá como levantar a geografia de cada lugar e demonstrar, cartograficamente, a realidade tanto da escola de várzea (Menino Deus - Itaboraí do Meio) quanto de terra firme (Santa Maria - Vila Amazônia) e de outras comunidades do município de Parintins. Também representar as dinâmicas exercidas na várzea com as de terra firme em relação e todos os aspectos geográficos. O estudo das realidades locais de ensino, pelos estudantes ribeirinhos, facilitarão a leitura e análise de suas realidades geográficas numa dimensão regional, apesar de terem suas particularidades e singularidades locais.

A escala cartográfica, outro elemento importante como componente curricular, dará uma visão dos lugares vividos nos afazeres diários, onde o estudante ribeirinho poderá desenvolver o seu olhar no que diz respeito à área e a distância entre os lugares percorridos ou a cidade (Parintins) e a comunidade de várzea (Itaboraí do Meio) ou de terra firme (Vila Amazônia). Para tanto, poderia manusear Carta de 1/100.000 ou inúmeros mapas existentes nos atlas, se a escola fosse dotada de todos estes recursos. Além das distâncias, o estudante estabeleceria comparações entre os lugares.

A escala dos fenômenos, outra ferramenta importante na aprendizagem do estudante, permitiria ver as dimensões espacial e temporal nas escolas das comunidades ribeirinhas, no sentido de deixar perceptível a dinâmica da sazonalidade da várzea e de terra firme e sua interferência na vida dos sujeitos da comunidade e da escola. Até porque, várzea e terra firme, possuem características diferentes tanto no modo de vida quanto na relação de produção, na relação social e cultural. O ensino de geografia na escola ribeirinha se completaria porque deteria leitura acurada da característica das escolas ribeirinhas de várzea e terra firme tanto do município de Parintins como de outros municípios do Estado do Amazonas ou mesmo da Amazônia. Por isso, a inserção do estudo de escala no currículo da escola ribeirinha pode estabelecer relações de análises do fenômeno do local para o regional ou vice versa.

Em relação às classes da legenda, pesos atribuídos às variáveis, dependerão do grau de importância e dimensão do que se está pretendo ensinar. Deste modo, estaria na medida do possível, sendo inserida na base curricular do ensino de geografia a proposta de mapa mental 
de Nogueira $(2002 ; 1994 ; 2006$, p. 95), que trabalha a partir da percepção do morador e conhecedor de cada lugar, fortalece esta base discussão quando expressa a leitura e compreensão dos comandantes de barcos regionais do Amazonas ao levantar a hipótese de "[...] que os comandantes possuem conhecimento preciso das rotas e se localizam e se orientam a partir da experiência adquirida no espaço de circulação vivido diariamente por eles. Este saber é organizado mentalmente por eles, tomando forma de Mapas Mentais, perfeitas representações de toda a região percorrida". Estes aspectos podem se tornar alicerce fundante do ensino de geografia nas escolas ribeirinhas de Parintins.

Outras contribuições para esta discussão sobre escola, currículo e ensino de geografia encontram-se em Pontuschka, Paganelli, Cacete (2007) - Para ensinar e aprender Geografia; em Rego, Aigner, Pires e Lindau (2003) - Um pouco do mundo cabe nas mãos: geografizando em educação o local e o global; em Kimura (2008) - Geografia no ensino básico: questões e propostas; em Castrogiovanni, Callai, Schäffer, Kaercher (2003) Geografia em sala de aula: práticas e reflexões; Schäffer, Kaercher, Goulart, Castrogiovanni (2005) - Um globo em suas mãos: práticas para a sala de aula. São contribuições importantes para pensar e repensar a escola existente, o currículo que está sendo praticado e o ensino de geografia que ainda não se desprendeu das amarras do provincianismo e colonialismo, reproduzindo informações ou conteúdos que não representam importância para a construção de vida do estudante ribeirinho. É importante frisar que a leitura destes autores corresponde a uma visão de cidade, mas os conceitos, categorias geográficas e toda orientação metodológica são eixos importantes de condução de leitura de mundo e devem ser utilizadas para a transformação da escola, do currículo e do ensino de geografia, abrindo espaço para associar e se apoderar do saber tradicional existente em cada sujeito construtor de sua própria história e lugar de vida.

Assim sendo, o ensino de geografia nas escolas ribeirinhas ganharia uma dimensão diferenciada, daria resposta mais significativa e atenderia aos interesses dos estudantes, no sentido da aplicação na prática dos conteúdos de geografia estudados.

\subsection{As escolas: Tiradentes, no Itaboraí do Meio e Tukasa Uetsuka, na Vila Amazônia}

Dois lugares próximos, para a dimensão da Amazônia, mas completamente diferentes em sua formação social, cultural e em suas atividades econômicas. Uma das diferenças significativas existentes está na formação comunitária de lugar. A do Itaboraí do Meio - 
Menino Deus - se deu pela vontade de cada comunitário em ter tudo que fosse de melhor para atender os seus filhos e para outros moradores, e assim aproximá-los mais do centro comunitário. Para tanto, a luta foi iniciada para melhorar as condições do prédio escolar e também dar uma nova infraestrutura ao quadro comunitário, construindo o templo religioso e em seguida vieram outras conquistas como o ensino de sexto ao nono ano do ensino fundamental e atualmente com o ensino médio via satélite. Vila Amazônia, ao contrário, guarda o processo de colonização japonesa, portuguesa e com uma parcela pequena dos chineses, porém, recebendo mais atenção do poder executivo em termos de infraestrutura.

Estas comunidades, assim como outras do município de Parintins, são banhadas pelo rio Amazonas. A Itaboraí foi erguida sobre terreno do quaternário (várzea) e a segunda sobre terreno do terciário (terra firme). As duas comunidades são diretamente afetadas pelo fenômeno de terras-caídas, deixando os moradores em alerta, já que não encontraram um meio para reter ou controlar o avanço da erosão fluvial. Este fenômeno atinge tanto os terrenos de várzea quanto os de terra firme, que chega às margens do rio Amazonas. São excelentes aspectos de estudo dentro da geomorfologia e geomorfologia fluvial. Nesses frágeis terrenos encontram-se edificados o prédio escolar, importantes templos de produção de saber formal dentro de todo um espaço de produção de saber não-formal. Estão também construídos o templo religioso, a sede social e as inúmeras casas dos comunitários, além da área de lazer, o campo de futebol. Os moradores passam a exercer certa vigilância sobre o avanço das terras-caídas para que possam providenciar as mudanças dos prédios ou das residências. A atenção se faz quando o terreno apresenta fissuras, ocorridas pelo solapamento e em seguida a potencial ocorrência do deslizamento ou desmoronamento de trechos do terreno. Isto representa sempre um perigo: quando não está sobre os prédios, está sobre as embarcações atracadas nos portos das comunidades.

As escolas - Tiradentes e Tukasa Uetsuka ${ }^{11}$ - de cada comunidade atende crianças de outras comunidades próximas. Na várzea, o transporte é o barco regional e na terra firme, ônibus. Os estudantes de sexto ao nono ano estudam no horário da manhã; os estudantes de alfabetização, primeiro ao quinto ano, estudam à tarde. O recurso para manter o transporte escolar é de origem federal.

\footnotetext{
${ }^{11}$ Estas escolas foram construídas distantes da margem do rio para evitar danos causados pelas terras-caídas e assim mantém certa margem de segurança sobre este perigo da erosão fluvial. Porém, é importante destacar que a pressão hidráulica do rio Amazonas, faz avançar a cada ano a erosão, reduzindo a margem de proteção e segurança, não só do prédio escolar mas das residências dos comunitários.
} 
Estas duas comunidades trazem a história de sua organização sócio-espacial a partir da história de seus construtores que organizados se mobilizaram para conseguir os seus objetivos traduzidos em benefícios para seus filhos, assim como a herança deixada por imigrantes participantes do espaço socialmente organizado no município de Parintins.

Um breve resumo de cada comunidade e seu processo de construção espacial.

A comunidade do Itaboraí do Meio, conhecida como Menino Deus, onde se encontra a Escola Tiradentes, tem o prédio escolar todo em madeira, com assoalho que chega a $1 \mathrm{~m}$ ou $1,5 \mathrm{~m}$ de altura, por causa da enchente. O prédio da escola é coberto de telha de amianto brasilit, possuindo seis divisões, sendo: uma para a diretoria e secretaria, quatro salas de aula, cozinha e cantina.

As casas da comunidade estão distribuídas a partir do templo religioso no centro e as casas dispostas, tanto para o lado direito quanto para o lado esquerdo, acompanhando a margem do rio. As casas dos moradores todas são em madeira e em forma de palafitas (casas de assoalho sobre estacas ou troncos), para enfrentar o período das cheias.

A história de fundação da Comunidade Menino Deus - Itaboraí do Meio está assim descrita pela gestora da Escola Municipal Tiradentes, Professora Vânia Maria de Mattos $\operatorname{Santos}^{12}$ :

De uma maneira bem resumida, podemos dizer que a Comunidade de Menino Deus, localizada à margem esquerda do Rio Amazonas, lugar Itaboraí do Meio, Parintins Amazonas, foi fundada dia 09 de maio 1979 pelas seguintes pessoas: Professora Vânia Maria de Mattos Santos, Deodoro de Souza Santos, Mailson Fernandes da Silva, Maria Alice Oliveira Silva e comunitários. Foi em uma reunião de pais e mestres da Escola Municipal Tiradentes onde se faziam presentes 19 pais de família que, ao sentir a necessidade de apoio para melhorar o espaço físico, para atender 63 alunos, pois a escola era de chão-batido e coberta de palha, pois quando chovia se transformava em lama. A professora Vânia Maria de Mattos Santos tomando a iniciativa para encontrar a solução para o referido problema resolveu convocar os comunitários para uma novena à noite, foi um encontro maravilhoso e bem participado, pois de um a um eram roladas as bolinhas do terço, e que com todo ardor rezavam e cantavam hinos à Nossa Senhora e estes encontros se repetiram durante a enchente, que logo mais com a vazante todos se dispuseram a construir a igreja cujo o padroeiro era o Menino Deus que sempre foi venerado pela família da Sra. Maria Alice Oliveira. Para dar continuidade aos trabalhos da Igreja que já estava sendo construída com a colaboração dos comunitários. Dando prosseguimento aos trabalhos todos se empenharam a pescar para comprar os materiais necessários para que até o dia 23 de dezembro pudesse estar concluída a Igreja, pois nesta data seria celebrada a primeira festa do Padroeiro com a presença do Pe. Emilio Bothely que era o pároco do Sagrado Coração de Jesus a qual pertencíamos.

\footnotetext{
${ }^{12}$ Foi mantida a escrita original da Gestora para não alterar o sentido do que foi escrito, pois representa a vida cotidiana de todos os membros da comunidade e todo processo de diálogo, de organização para a aquisição de bens importantes para todos os comunitários desta e de outras comunidades próximas.
} 
Histórico repleto de expressão de vida e relações sociais e culturais do lugar. Expressa a vida em comunidade e sua jornada participativa de construções de benfeitorias para cada morador. Deixando evidente a participação ativa e a decisão coletiva para conseguir pleitear uma estrutura melhor para o prédio escolar.

As decisões coletivas sempre se traduzem em resultados positivos e importantes para a comunidade. Assim deveria ser a construção da proposta curricular, através de discussão até se chegar a um consenso para se ter fluência no processo ensino-aprendizagem e não a estagnação ou fragmentação do que é ensinado ou aprendido nas escolas ribeirinhas.

Esta escola vive a eterna sazonalidade do rio Amazonas. No momento do período da cheia - em que os professores e estudantes procuram dar um jeito de não deixar molhar os equipamentos - e no período da vazante, vivem a normalidade do lugar, plantando, criando e preparando-se para a próxima enchente. Porque não há previsão se no ano seguinte a cheia vai ser grande ou se vai ser pequena. Em todo caso, os moradores da várzea vivem sempre uma expectativa de estar pronto para iniciar tudo como se fosse à primeira vez - é sempre um recomeçar. A dinâmica constante para quem vive na beira do rio Amazonas.

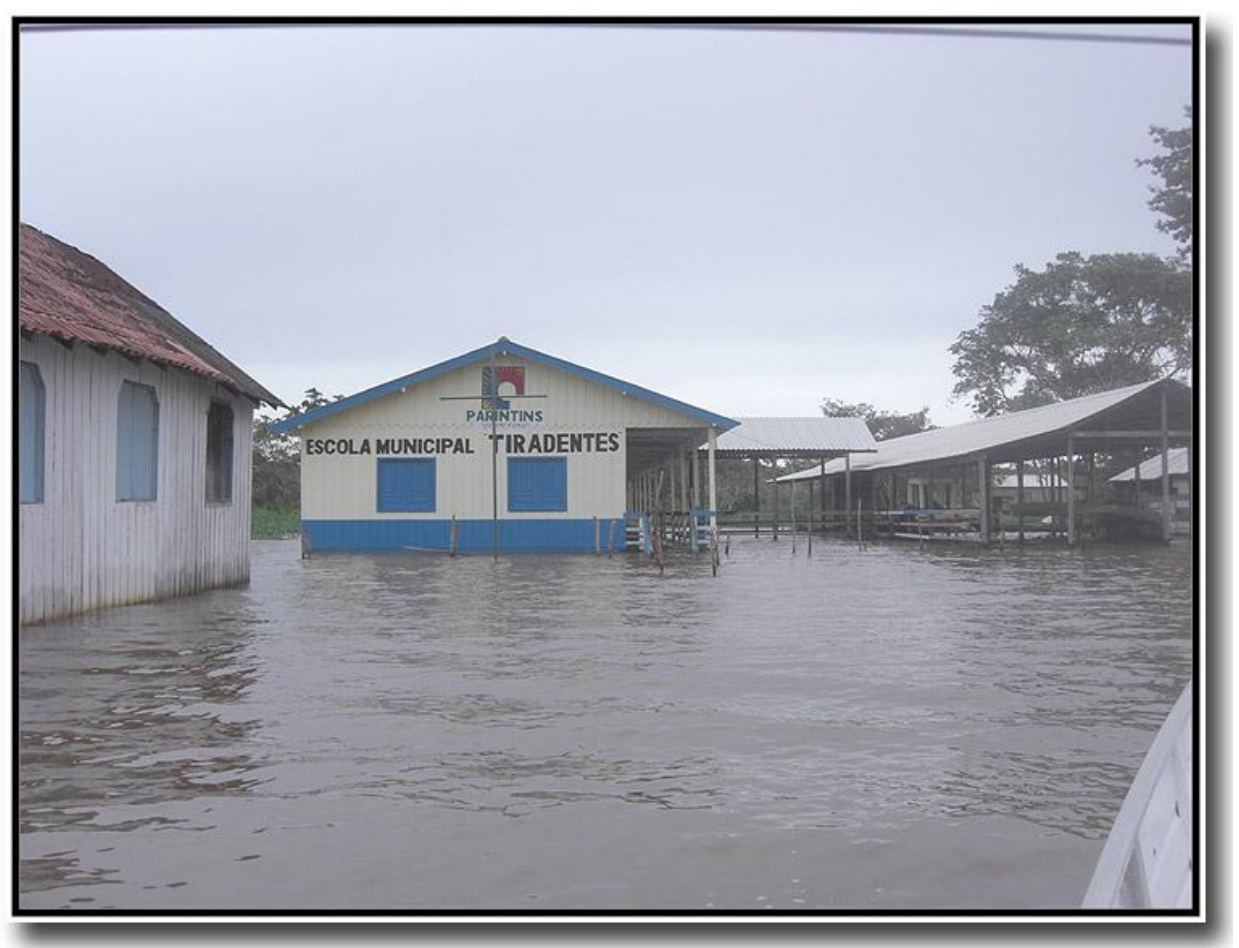

Figura 17 - Escola Tiradentes - cheia de 2009.

Foto: Camilo Ramos/ maio de 2009 


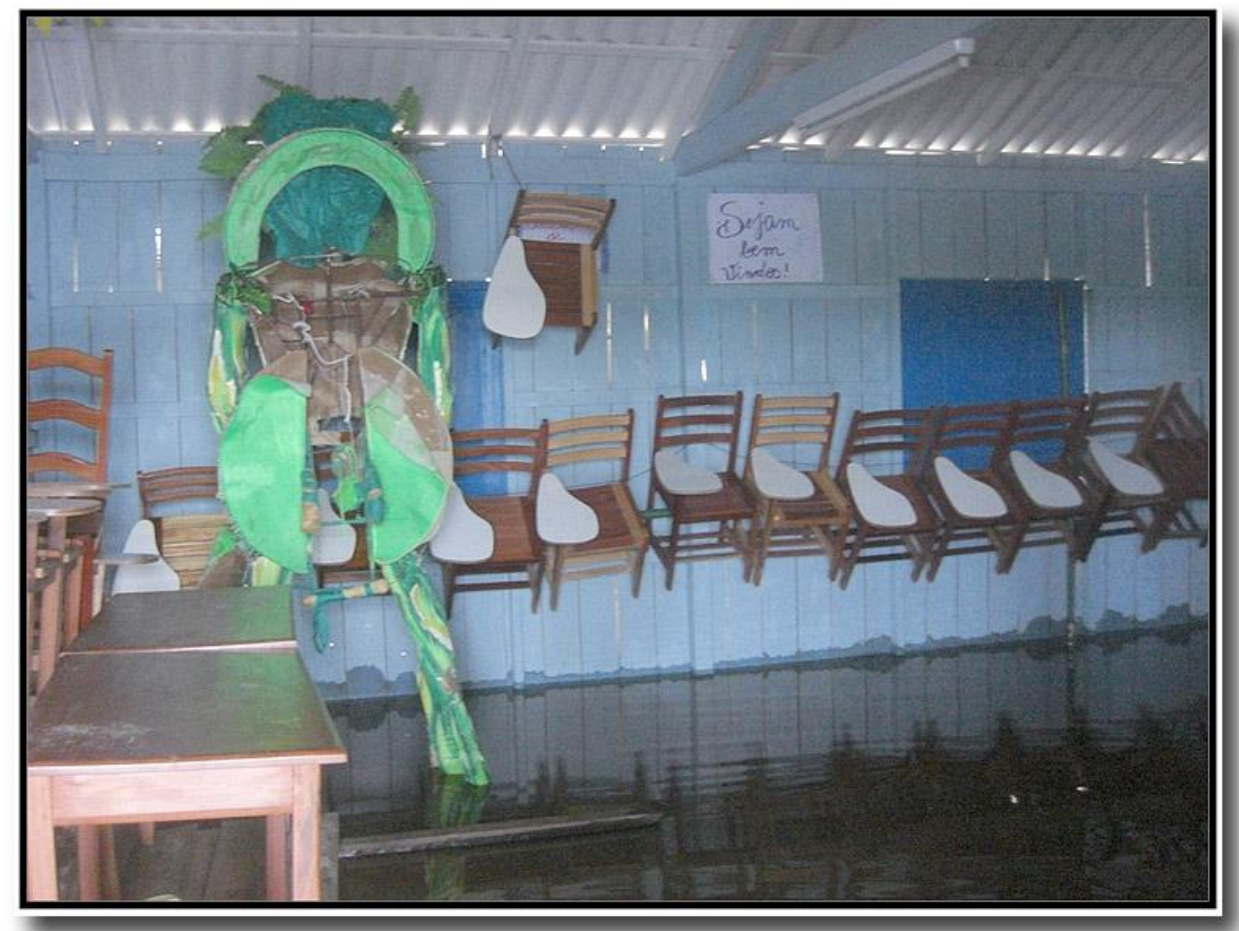

Figura 18 - Escola Tiradentes - sala de aula - cheia de 2009.

Foto: Camilo Ramos/ maio de 2009

A história da comunidade se confunde ou se funde com a história da própria escola, onde os seus construtores, sujeitos ribeirinhos, atentos aos processos de mudança e a vontade de querer sempre o melhor para seus filhos, lutaram para conseguir o pretendido: um prédio escolar estruturado. Este prédio contém a escola e todo processo condutor de mudanças a partir do esforço de cada professor para ensinar e assim oportunizar os estudantes irem sempre à busca de novos conhecimentos, deixando claro o sentido de escola ribeirinha ou a escola da água. Mantém-se o relato fiel da gestora da Escola, Professora Vânia Maria de Mattos Santos, para não interferir ou alterar o sentido do relato histórico. Esta professora sempre foi o esteio da comunidade e sempre lutou para conseguir o melhor para os comunitários. Uma verdadeira e incansável líder comunitária. 


\section{Histórico da Escola Municipal Tiradentes}

Bem precisamente o mês de dezembro de 1969 quando Vânia Maria de Mattos Santos voltava de férias para o aconchego de seus pais Sr. Domingos de Souza Mattos e D. Cleia Melo de Oliveira. Seus conhecidos e parentes, vendo o seu desenvolvimento, já estava apta a cursar o ginásio, pediram então que ela lecionasse seus filhos, pois não havia escola no local. Mais precisamente pelo dia 10 de dezembro Vânia iniciou o trabalho com 67 alunos e foi denominada Escola de São Francisco, pois a mesma era remunerada pelos pais. Ao passar os meses de dezembro, janeiro, fevereiro e março as águas alagaram a terra que foi preciso parar as atividades com os alunos que logo mais em agosto do mesmo ano a jovem professora se dirigiu a prefeitura levando em mãos a matrícula com 69 nomes de crianças $e$ jovens que precisavam ser alfabetizados. A mesma foi atendida pelo então prefeito Djard Vieira que a contratou por durante oito meses. Na década de 70 foi transferida a escola para o terreno do Sr.Deodoro de Souza Santos que era denominada Tiradentes, ficando assim o nome da referida escola: Escola Municipal Tiradentes, que já funcionava de $1^{a}$ a $4^{a}$ série e o curso de alfabetização o (MOBRAL) onde foram alfabetizados 40 pessoas durante três anos foi uma conquista. Considerando a distância que as crianças andavam de canoa ou por terra foi feito o acordo para que a escola fosse levada para outro lugar chamado Santa Luzia. A mesma foi construída em chão batido coberto de palha pois quando chovia se transformava o chão em lama e nisto os alunos e a professora rezavam as Ave-Marias pedindo ao Pai do Céu que não custasse passar o temporal. Somente em 1982 na gestão do prefeito Gláucio Bentes Gonçalves foi construída uma sala de aula e o pátio que, logo depois os comunitários fizeram a cozinha. Ao passar dos anos vimos que seria interessante que os discentes avançassem em seus estudos e a professora Vânia, que sempre se preocupou com avanços da referida escola, logo pensou em uma possibilidade de se conseguir uma $5^{a}$ série propondo assim a estada do homem em seu lugar no campo evitando o êxodo rural. Para isso acontecer foi preciso usarmos os anexos da propriedade da comunidade pois quando dava os temporais os professores e alunos se punham num cantinho rezando e pedindo que Deus os livrassem de um pedaço de telha na cabeça.E assim continuavam as atividades e os avanços da clientela escolar. Passaram-se os anos e a ansiedade por uma escola de boas condições era muito grande e esperançosa por todos. Somente em 2007 na gestão do atual prefeito Frank Luís da Cunha Garcia foi construída a escola dos sonhos com 05 salas de aula, 01 secretaria, 01 cantina e o corredor amenizando assim as dificuldades dos estudantes. Em 2009 tivemos a felicidade de formar 37 alunos no ensino médio que já estão no processo de graduação, afinal de contas é papel da escola ajudar os alunos a desenvolver uma postura mais crítica e construtiva. Hoje a escola tem 159 alunos e caminha muito bem. Gestora da Escola Vânia Maria de Mattos Santos.

A opção de manter aqui a escrita original da informante foi para não interferir no que foi dito ou escrito pela mesma, porque as lições vivenciadas conduziram a refletir sobre o processo de construção das pessoas, no sentido da unidade apesar de viverem suas heterogeneidades.

O relato, tanto do histórico da comunidade quanto da escola, evidencia a forma coletiva de trabalhar dos comunitários e sua organização de reivindicar e lutar por seus direitos. Apresenta os problemas enfrentados e as tentativas de solução, sem perder a vontade 
de ensinar da professora como também a vontade de aprender dos estudantes e a luta pelos direitos dos comunitários. Todos juntos concretizando os objetivos de efetivar mudanças na comunidade a partir da escola e das ações coletivas.

Os detalhes das informações relatadas demonstram a organização sociocultural, socioambiental e socioeconômica pretendido por Paulo Freire e Moacir Gadotti e muitos outros educadores pesquisadores, ou seja, o projeto de um currículo intertranscultural não está distante de acontecer, pode ocorrer pelo processo de organização dos sujeitos envolvidos diretamente com o processo educativo das escolas ribeirinhas amazônicas, recuperando o que foi trabalhado, em termos de projetos e ações, pelo Instituto de Educação do Amazonas.

Em relação ao ato de ensinar, as reuniões para tomadas de decisão comunitárias são lições ensinadas aos jovens estudantes, porque no futuro bem próximo serão eles a estarem tomando as decisões, como líderes, para a melhoria e a reestruturação da comunidade e da escola.

A comunidade de Santa Maria de Vila Amazônia ${ }^{13}$ possui um processo histórico diferente da comunidade de Menino Deus. O início da história está marcado com a assinatura de um contrato de concessão de terras entre o governo do Estado do Amazonas e o embaixador do Japão no Brasil, em 1929. Neste contrato o governo do Estado concedia 1.000.000 (um milhão) de hectares de terras, deixando a escolha da área por conta dos concessionários. A área escolhida compreendida entre o Rio Madeira e o limite do Estado do Amazonas com o Pará, porque possui a maior faixa de várzea com comunicação direta com a terra firme e a facilidade de circulação pela rede hidrográfica. $O$ convite se deu em decorrência da crise da borracha de 1911 e o governo do Amazonas viu nos japoneses a saída para crise que assolava o Estado e a região Amazônica. Neste período da crise, o Amazonas passou a depender de outros Estados adquirindo produtos básicos para alimentação, como por exemplo a farinha.

Os japoneses trabalharam com intuito de construir uma cidade para receber 10.000 (dez mil) famílias que viriam do Japão. Assim a sede do projeto tinha hospital, Hakoo Kaikan

\footnotetext{
${ }^{13}$ Os dados históricos resumidamente apresentados sobre Vila Amazônia são resultados de um projeto de pesquisa de iniciação científica desde 1993/1994. O trabalho de pesquisa tenta resgatar sobras de documentos que ainda existem sobre o processo de colonização japonesa no Amazonas. Durante a Segunda Guerra Mundial, foram retidos e todo registro foi extraviado como se quisessem apagar da Historia do Amazonas este acontecimento. Deste trabalho de pesquisa resultou artigo em jornal, em revista acadêmica e capítulo de livro. Dessa forma tenta-se mostrar como Vila Amazônia foi construída pela participação dos japoneses que se empenharam em construir um lugar para que pudessem viver com qualidade. Posteriormente, o empresário português J.G. Araújo deu um novo impulso de desenvolvimento à Vila realizando novas construções e, com a participação rápida dos chineses, Vila Amazônia viveu outro momento de organização e construção de seu espaço.
} 
(templo), casas para trabalhadores, casas para visitantes, serrarias, armazéns e todo um planejamento de produção agrícola e pecuária. Foi erguida como Instituto Amazônia, dividido em quatro áreas: estudo e pesquisa, meteorologia, agricultura e saúde (SOUZA, JOSÉ CAMILO, 2011). A parte tocante à saúde o Dr. Toda trabalhava manipulando ervas, raízes, cascas, resinas, óleos naturais, no tratamento de diversas doenças. Enfermos de Manaus e Belém se deslocavam para se tratar no hospital de Vila Amazônia. Os japoneses abriram estrada, sistema de esgoto e toda uma infraestrutura de cidade foi construída. O Instituto possuía várias áreas de produção fora da sede principal, sendo: Uaicurapá, Mamuru, Andirá e até no município de Maués, para onde os estudantes (kotakusei) recém-chegados à Vila Amazônia eram destinados para colocarem em prática tudo que aprenderam no Japão e assim contribuírem na produção agrícola e pecuária. Os estudantes tiverem que se adaptar ao modo cultural dos amazônidas e as imposições naturais da Amazônia como picadas de insetos, às intempéries e introduzir novos elementos no habito alimentar, apesar de produzirem hortifrutigranjeiro.

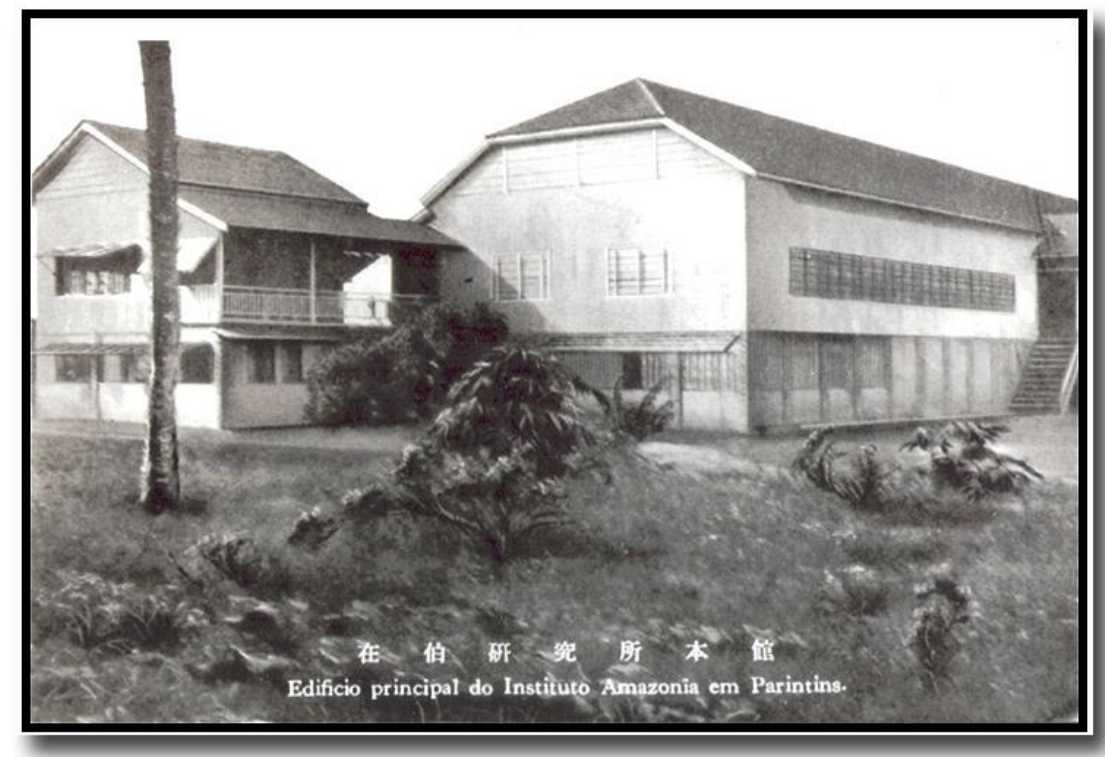

Figura 19 - Prédio principal do Instituto Amazônia. No térreo funcionava o comércio e na parte superior alojamento dos kotakuesei. No prédio menor parte administrativa.

Fonte: Arquivo Camilo Ramos 


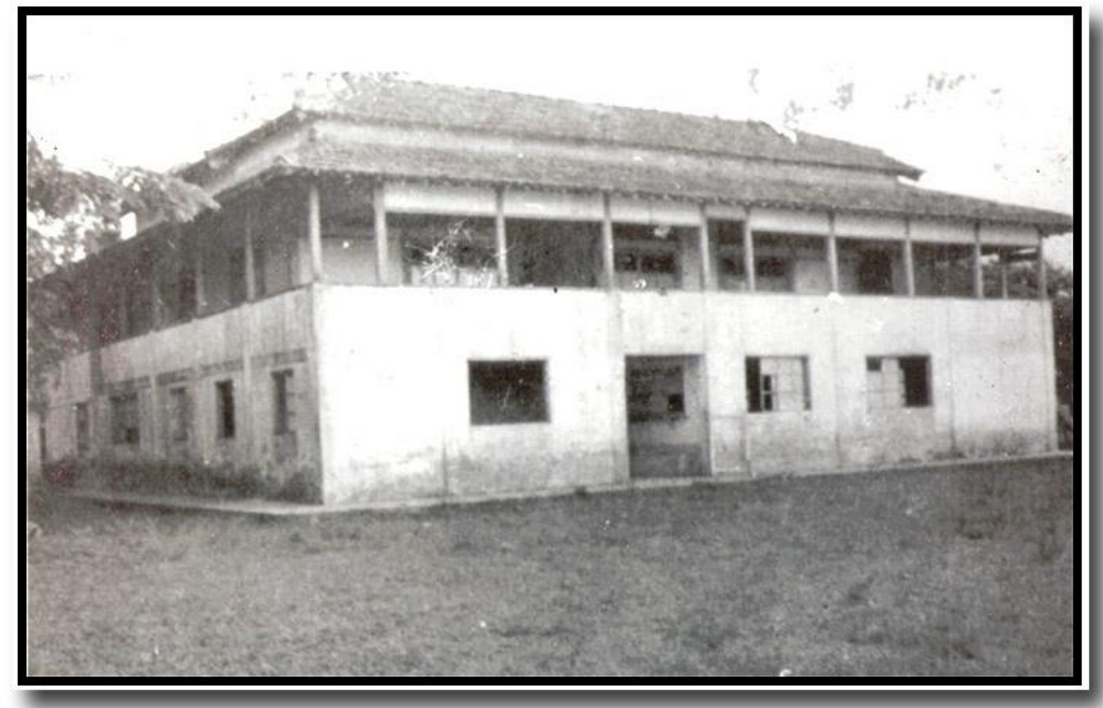

Figura 20 - Hospital do Instituto Amazônia. Estava sob a direção do Dr. Toda, que utilizava da farmácia natural. Hospital atendia pacientes oriundos de Manaus e Belém.

Fonte: Arquivo Camilo Ramos

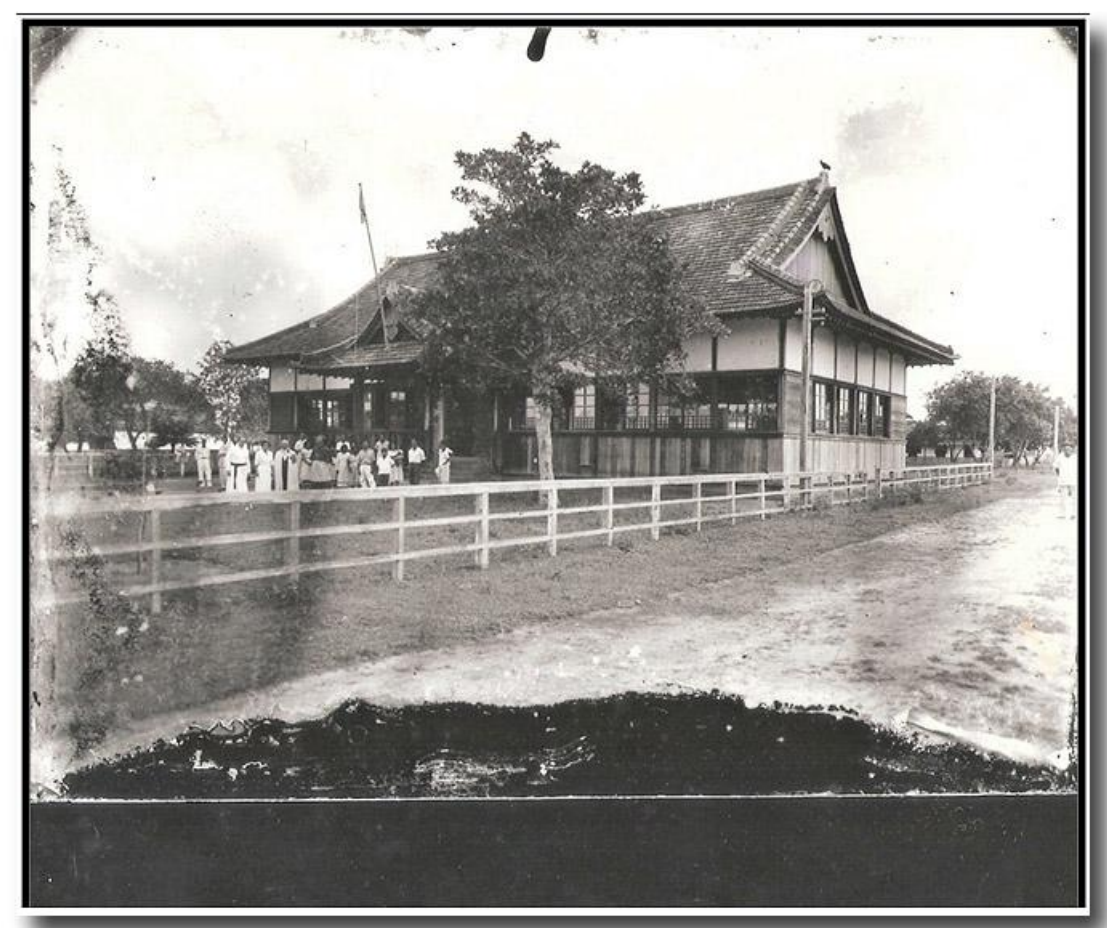

Figura 21 - Hakoo Kaikan

Fonte: Arquivo Camilo Ramos

Os japoneses passaram a produzir juta em grande escala, nas várzeas, após Ryota Oyama ter conseguido adaptar à região as sementes oriundas da Índia. Nas colônias de produção da terra firme produziram, consorciados com a floresta, abacaxi sem espinho, milho, mamão, guaraná etc.; praticavam o extrativismo, coletando: castanha do Brasil, sorva, látex, 
madeira, etc. Com a crescente produção agropecuária, o Instituto passou para a razão de Companhia Amazonense, onde foi investido um milhão de ienes. Como companhia passou a abastecer São Paulo com fibras de juta para a indústria têxtil fabricar sacas de armazenar café, passou a ter plantações de juta até São Paulo de Olivença no Alto Solimões. Mantinha filial no nordeste brasileiro e até na Grande São Paulo. Outro compromisso da Companhia era a produção de fibras para atender a indústria têxtil do próprio Japão.

Em 1942, no auge da Segunda Guerra Mundial, os japoneses foram presos e tudo que construíram passou a ser espólio de guerra. Foram levados ao Acará - Pará, em uma espécie de campo de concentração. Apenas dois kotakusei receberam salvo-conduto do então governador, Álvaro Maia, para circular no Amazonas: Ryota Oyama e Dr. Toda. Os que não foram presos se refugiaram no meio da mata. O Sr. Shoji, foi preso na cidade de Barreirinha Amazonas e levou quarenta chibatadas com couro de peixe-boi; foi salvo por Ryota Oyama.

Em 1950, Vila Amazônia foi vendida ao empresário português de Manaus que implantou um novo ritmo de desenvolvimento, construindo templo religioso, casa com vários quartos e inclusive sala de projeção de cinema. Mantinha um comércio para atender os seus trabalhadores e também toda população de outras comunidades próximas e distantes. Aceitava tanto dinheiro quanto produtos extrativistas ou animais pela mercadoria ali comercializados.

Conseguiu implantar um sistema de eletricidade, com iluminação pública das ruas abertas na Vila Amazônia, melhor do que o da cidade de Parintins.

Importou gado de raça para melhorar o seu rebanho e manteve uma pequena indústria para o aproveitamento dos derivados de leite. Levou trator de esteira para agilizar a derrubada da floresta, transformando em campo de pastagem para os animais e em monocultivo agrícola: cana-de-açúcar, sisal, outros produtos agrícolas e hortifrutigranjeiros.

Neste período de grande produção, foi mantido e conservado os dois portos construídos pelos japoneses: um no rio Amazonas e outro no Paraná do Ramos, onde atracavam os navios que chegavam para transportar toda produção agrícola e pecuária da Empresa J.G. Araújo de Vila Amazônia. 
Pelo padrão desenvolvimentista que se apresentava em Vila Amazônia ${ }^{14}$ recebeu visita de Ministro da Pasta da Agricultura no sentido de dar apoio e incentivar a produção de Vila Amazônia. Este apogeu permaneceu até a década de 1960, vindo entrar em decadência pelas inúmeras crises econômicas que o Brasil passou a enfrentar.

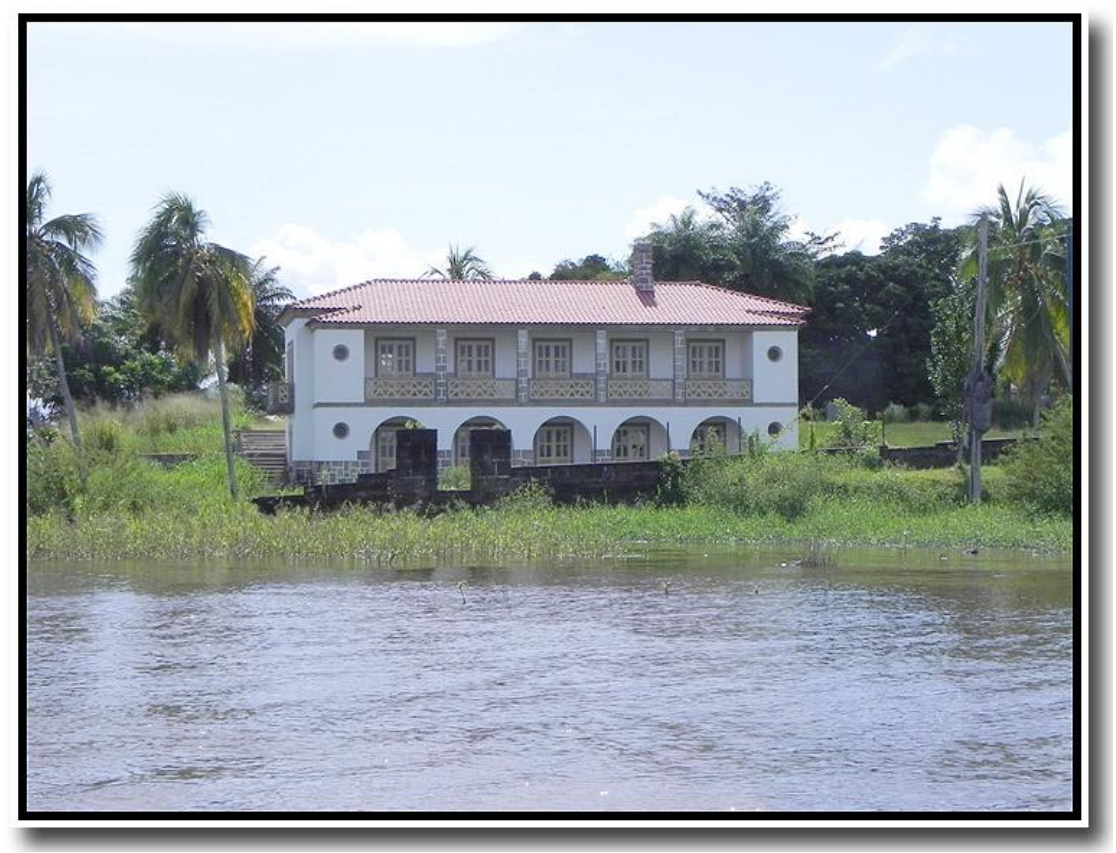

Figura 22 - Casa de J.G. Araújo em Vila Amazônia - construída em 1950/1951. Foto: Camilo Ramos - Abril/2012

Em 1967, o empresário J.G. Araújo, proprietário de Vila Amazônia, vendeu aos chineses e estes implantaram uma fábrica de papel chamada PAPELAMAZON ${ }^{15}$, tendo por finalidade transformação da imbaúba em papel. Porém, viram a dificuldade de plantação deste vegetal e, em dois anos, abandonaram o projeto devolvendo a Vila Amazônia ao empresário J.G. Araújo. Este vendeu, no início da década de 1970, aos empresários de Belém. A partir deste momento entrou em decadência e todo patrimônio arquitetônico transformou-se em ruína.

\footnotetext{
${ }^{14}$ Foi mantida a visão positivista apenas pela necessidade de manter o registro do acontecimento histórico para poder compreender o processo de construção sócio espacial de Vila Amazônia. Nas imagens de filmes da época há todo registro da exploração capitalista, resquício do aviamento, dentro da Amazônia e mantido na Vila Amazônia. Esta discussão pode ser aberta e aprofundada nas salas de aula da escola. É importante rever a história criticamente para compreender todo processo de construção sociocultural que se tem registro do espaço de Vila Amazônia. E assim projetar para as referências e os acontecimentos sociopolíticos, socioeconômicos, ambientais e culturais pelos quais passava o Brasil e o mundo.

${ }^{15}$ Ainda é possível ver as ruinas e as máquinas deixadas nas proximidades de Vila Amazônia. É um lugar que conserva muitos pés de castanheiras que foram cultivadas no período dos japoneses e depois conservadas pelos chineses.
} 
Vila Amazônia foi transformada em área federal de assentamento no final de $1980 \mathrm{e}$ início de 1990, sofrendo transformação pelo processo de ocupação e assentamento, sendo considerada, pelos moradores, um bairro da cidade de Parintins. Foi erguida uma escola na década de 1990, em alvenaria, coberta de telha de barro, toda equipada, para funcionar como escola agrícola, semi-internato ou internato. Mas o projeto foi abandonado e tudo que existia foi saqueado. No prédio funciona, atualmente, a Escola Tukasa Uetsuka, comportando em média 600 alunos em dois turnos.

Diferentes formações da comunidades em seus processos de construção históricoespaciais. Estes lugares têm definições, tem marcas e sentidos diferentes, porque segundo Yi Fu Tuan (1983, p.20) “o lugar é um tipo de objeto. Lugares e objetos definem o espaço, dando-lhe uma personalidade geométrica. [...]. Objetos e lugares são núcleos de valor. Atraem ou repelem em graus variados de nuanças. [...]”. Todo lugar tem sua marca de construção a partir dos sujeitos que a construíram, porque reconhecem sua realidade e seu valor.

Este conjunto de informações compõe a geografia existente nas comunidades ribeirinhas, ligada ao conjunto da Geografia Cultural, Geografia Agrária e Geografia da População e de todo processo da imigração, emigração, migração campo-cidade, migração várzea terra firme, migração pendular, as quais não estão inseridas no componente curricular em nenhuma escola do município de Parintins.

\subsection{Ensino Seriado: águas turvas do conhecimento}

O conjunto de informações descritas permite projetar a aproximação da realidade socioeducativa do município de Parintins, principalmente da exercitada na Escola Tiradentes e na Escola Tukasa Uetsuka. Realidade remete ao conjunto formal da organização escolar para se tirar parâmetros dentro da realidade brasileira. As ações educativas desenvolvidas em cada escola pesquisada em Parintins deveriam estar voltadas para contribuir com o desenvolvimento produtivo e socioeconômico dos pais de alunos e demais comunitários.

Não é para pensar uma escola agrícola mas pensar e planejar uma escola onde os conteúdos abram possibilidades organizativas e participativas diretamente voltadas para contribuir com uma visão renovadora da produção agropecuária e do crescimento econômico, juntamente ao crescimento social de cada família comunitária. Qual o sentido ou para que aprender matemática? Por que estudar e aprender Geografia? Também não é pensar o sentido prático da aplicação dos conteúdos, mas como os estudantes poderão utilizar a Geografia para pensar e planejar o seu lugar de vida, reconhecendo os vegetais e sabendo da importância de 
cultivar consorciado com a floresta. Saber mapear os lugares ou georreferenciar, saber identificar o solo e o cuidado que deve ter para evitar erosão pluvial, ou seja, saber o que está aprendendo serve para sua vida pessoal e profissional. A matemática ajudaria o estudante saber calcular quanto pode produzir em um hectare e quanto vai investir no transporte, comercialização e qual será seu lucro final. Dependendo da estruturação e planejamento dos conteúdos, todas as disciplinas podem contribuir para se ter uma escola que abra perspectiva de aprendizagem significativa, interdisciplinar e transdisciplinar, para ser chegar a um currículo intertranscultural. São caminhos a serem pensados e discutidos, para a transformação da escola atual e do processo ensino-aprendizagem. Nesta perspectiva as mudanças podem e tendem acontecer, porque segundo Semprini (1999, p.33)

[...]. Uma transformação social nunca é estritamente mecânica e quantitativa. Ela implica uma profunda reestruturação dos equilíbrios e posições, das identidades e das representações. A integração real não segue automaticamente a integração formal ou legal. A mudança que afeta a parte integrada repercute inevitavelmente sobre a parte integrante. [...].

Toda mudança na proposta escolar deve seguir um ritmo de planejamento para não ser julgada como rápida e forçada, e sim para dar solidez e concretude na execução como proposta de política pública e não proposta de governo. Assim, a estrutura do ensino vai ter repercussão positiva porque se originou em decisão coletiva.

Enquanto não acontece a apresentação de nenhuma proposta de mudança, segue-se a estrutura adotada no ensino brasileiro, de acordo com a Lei de Diretrizes e Base - LDB 9.394 de 20 de dezembro de 1996, em seu Capítulo II - Da Educação Básica -, Seção I-Das Disposições Gerais, que traz a seguinte redação no Artigo 22. "A educação básica tem por finalidades desenvolver o educando, assegurar-lhe a formação comum indispensável para o exercício da cidadania e fornecer-lhe meios para progredir no trabalho e em seus estudos posteriores". Este artigo da lei apresenta em si inúmeros questionamentos. O ponto central aqui pretendido está relacionado ao que fala sobre “desenvolver o educando". Da forma como está estruturado, o ensino escolar não atende o que diz a Lei, somente assegura de forma frágil à formação comum. Este artigo da LDB traz ainda a preocupação de assegurar o exercício pleno da cidadania, porém, há certa dificuldade em alcançar o proposto pela estruturação conservadora da escola. É preciso discutir e planejar as mudanças necessárias para que se alcancem os objetivos pretendidos de uma escola mais cidadã, trabalhando uma formação mais completa dentro da diversidade e complexidade da realidade amazônica e brasileira, com 
a participação de todos os sujeitos diretamente envolvidos no processo educativo, porque segundo Romão (2010, p. 67) é preciso ter a participação ativa dos mais interessados que são os membros das bases populares, dando voz e vez para quem conhece sua realidade:

[...]. O processo educacional libertador pode ajudar na construção desse apoio à soberania interna, na medida em que nascer das próprias bases populares de cada nação uma proposta educacional que forme para a cidadania plena, [...]. Esta educação não poderá desconhecer, em sua proposta curricular, os contextos complexos e contraditórios em que vivem e se desenvolvem as sociedades que lhe servem de referência. (grifo nosso).

Portanto, exigem-se mudanças, não para atender a lei, mas para construir uma base teórica sólida no sentido do educando poder exercitar sua cidadania, questionando a sua realidade e outras realidades próximas e distantes. Dando oportunidade para o estudante construir e estruturar novos conhecimentos a partir do aprendido em sala de aula associado ao aprendido com seus pais cotidianamente.

Esta maneira de pensar é romper com a estrutura escolar existente no sentido de construção de um novo sujeito entendedor do funcionamento do sistema com proposta de mudanças frente aos órgãos de decisão e da realidade vivida, com forte interesse em procurar criar, mediante conjunto de ações devidamente planejadas, condições favoráveis de aproximar o saber escolar do saber historicamente construído, dando resposta positiva aos processos produtivos e a própria produção, com possibilidades de elevar o nível de melhoria de vida dos membros da comunidade. A pretensão sempre será o crescimento intelectual dos estudantes para se tornarem agentes ativos e participativos no desenvolvimento socioeconômico da comunidade e dos sujeitos que a compõem.

Esta lei da educação brasileira dá liberdade ao processo de organização quanto às séries, para haver adaptações de acordo com as condições ambientais ou socioeconômicas existentes em cada lugar, conforme Artigo 23. "A educação básica poderá organizar-se em séries anuais, períodos semestrais, ciclos, alternância regular de períodos de estudos, grupos não seriados, com base na idade, na competência e em outros critérios, ou por forma diversa de organização, sempre que o interesse do processo de aprendizagem assim o recomendar". De acordo com este artigo da lei da educação, o ensino no município de Parintins e em suas escolas de terra firme são seriados e divididos por tempo de aula para cumprir 200 dias letivos ou 800 horas/aula. Em Vila Amazônia, estão assim constituídos: três primeiros tempos de cinquenta minutos e os últimos dois tempos de quarenta e cinco minutos. 
A escola possui três (3) sextos anos, com trinta e cinco (35) estudantes por sala, perfazendo um total de cento e cinco (105) estudantes. Há três (3) turmas do sétimo ano, com 30 estudantes em cada turma, perfazendo um total de noventa (90) estudantes. As duas (2) turmas do oitavo ano possuem vinte oito (28) estudantes por sala, num total de cinquenta e seis (56) estudantes. Tem uma turma do nono ano com apenas quarenta e dois (42) estudantes. O número de estudantes do ensino fundamental, de sexto ao nono ano, perfaz um total de duzentos e noventa e três (293), frequentando regularmente as aulas.

As aulas de Geografia estão assim divididas (Tabela 1 e 2) por tempo de aula e por ano de ensino:

\section{Horário de Aula}

\begin{tabular}{|c|c|c|c|c|c|}
\hline Tempo de Aula & $2^{\mathrm{a}}$ Feira & $3^{\mathrm{a}}$ Feira & $4^{a}$ Feira & $5^{\mathrm{a}}$ Feira & $6^{\mathrm{a}}$ Feira \\
\hline $\mathbf{1}^{\circ}$ & $6^{\circ}$ ano $\mathrm{C}$ & $6^{\circ}$ ano $\mathrm{C}$ & $\overline{---}$ & $7^{\circ}$ ano $\mathrm{A}$ & $\overline{---}$ \\
\hline $2^{\circ}$ & $6^{\circ}$ ano $B$ & $7^{\circ}$ ano $\mathrm{C}$ & $6^{\circ}$ ano $\mathrm{A}$ & $7^{\circ}$ ano $\mathrm{B}$ & $6^{\circ}$ ano $\mathrm{A}$ \\
\hline $3^{\circ}$ & $7^{\circ}$ ano $B$ & --- & $6^{\circ}$ ano $\mathrm{C}$ & $7^{\circ}$ ano $\mathrm{C}$ & $6^{\circ}$ ano B \\
\hline $4^{\circ}$ & --- & $7^{\circ}$ ano $\mathrm{B}$ & $7^{\circ}$ ano $\mathrm{A}$ & $6^{\circ}$ ano $\mathrm{A}$ & $7^{\circ}$ ano $\mathrm{C}$ \\
\hline $5^{\circ}$ & $7^{\circ}$ ano $\mathrm{A}$ & --- & $6^{\circ}$ ano B & --- & --- \\
\hline
\end{tabular}

Tabela 1 - Horário de aula do Professor Admilson/2012

\section{Horário de Aula}

\begin{tabular}{cccccc} 
Tempo de Aula & $2^{\text {a }}$ Feira & $3^{\text {a }}$ Feira & $4^{\text {a }}$ Feira & $5^{\text {a Feira }}$ & $6^{\text {a }}$ Feira \\
\hline $\mathbf{1}^{\mathbf{0}}$ & $9^{\mathbf{o}}$ ano A & --- & --- & --- & $8^{\circ}$ ano B \\
$\mathbf{2}^{\mathbf{o}}$ & --- & --- & --- & --- & \\
$\mathbf{3}^{\mathbf{o}}$ & --- & --- & --- & -- & \\
$\mathbf{4}^{\mathbf{0}}$ & --- & $8^{\mathbf{o}}$ ano A & --- & --- & \\
$\mathbf{5}^{\mathbf{0}}$ & $8^{\mathbf{o}}$ ano B & $9^{\mathbf{o}}$ ano A & --- & -- & $8^{\mathbf{o}}$ ano A \\
\hline
\end{tabular}

Tabela 2 - Horário de aula do Professor Antônio/2012

Com as mudanças da Lei, a Geografia perdeu espaço na escola deixando de ter três tempos semanais passando a ter somente dois tempos, de acordo com o mapa do horário semanal das aulas na Escola Tukasa Uetsuka. Esta mudança de redução do número de aula deixa o ensino da Geografia mais fragmentado e mais superficial. Ainda, em pleno século $\mathrm{XXI}$, são mantidos os resquícios deixados sobre a geografia como a disciplina em que "se decorando se aprende"; é preciso mudar esta visão nas escolas da Amazônia e mostrar o valor 
e a importância da geografia na reflexão sobre o lugar, sobre a realidade e ver o quanto pode ser fundamental para criticar toda e qualquer pobreza ou miséria existente no Brasil e no mundo, podendo contribuir com o desenvolvimento sociocultural das populações ribeirinhas a partir das estratégias de planejamento sobre o espaço ou lugar vivido.

Os professores da escola Tukasa Uetsuka, além de darem aula nesta escola, tem que se deslocar para ministrar aula em escola na cidade de Parintins. Saem de Parintins às seis horas da manhã e retornam ao meio dia. Esses professores são exemplos de migração pendular. Essa migração deveria estar sendo trabalhada em sala de aula a partir do seu exercício prática de ir e vir.

No horário da tarde são atendidos os estudantes de alfabetização e os de $1^{\circ}$ ao $5^{\circ}$ ano, na Escola Tukasa Uetsuka. Este arranjo foi necessário para atender os pequenos, porque a condução (ônibus escolar) passa muito cedo para conduzi-los até a escola. A escola atende as seguintes comunidades: Santa Maria - Vila Amazônia ${ }^{16}$ (onde se encontra a Escola); Cabeceira do Inferno - Zé Açu; Miriti; Colônia Flor de Maio - Miriti e Colônia Irmãos Coragem - Matogrosso. Para que todos consigam chegar no horário de sete horas para o início da aula, o ônibus inicia o percurso às quatro horas da manhã.

\footnotetext{
${ }^{16}$ O município de Parintins trabalha com denominação de comunidade e localidade. Comunidade está intimamente ligada ao pequeno povoamento, onde está o tempo religioso, a escola, o posto de saúde e as residências dos moradores e construtores daquele lugar. Localidade se refere a uma grande área, podendo ter uma ou mais comunidades. Podendo ser assim exemplificado: Vila Amazônia é uma localidade, possuindo apenas a comunidade de Santa Maria. Zé Açu é uma localidade e possui mais de cinco comunidades. Itaboraí é uma localidade e se divide em Itaboraí de Cima - possui uma comunidade; Itaboraí do Meio - possui duas comunidades e Itaboraí de Baixo - possui duas comunidades. A gleba de Vila Amazônia envolve localidades e várias comunidades.
} 


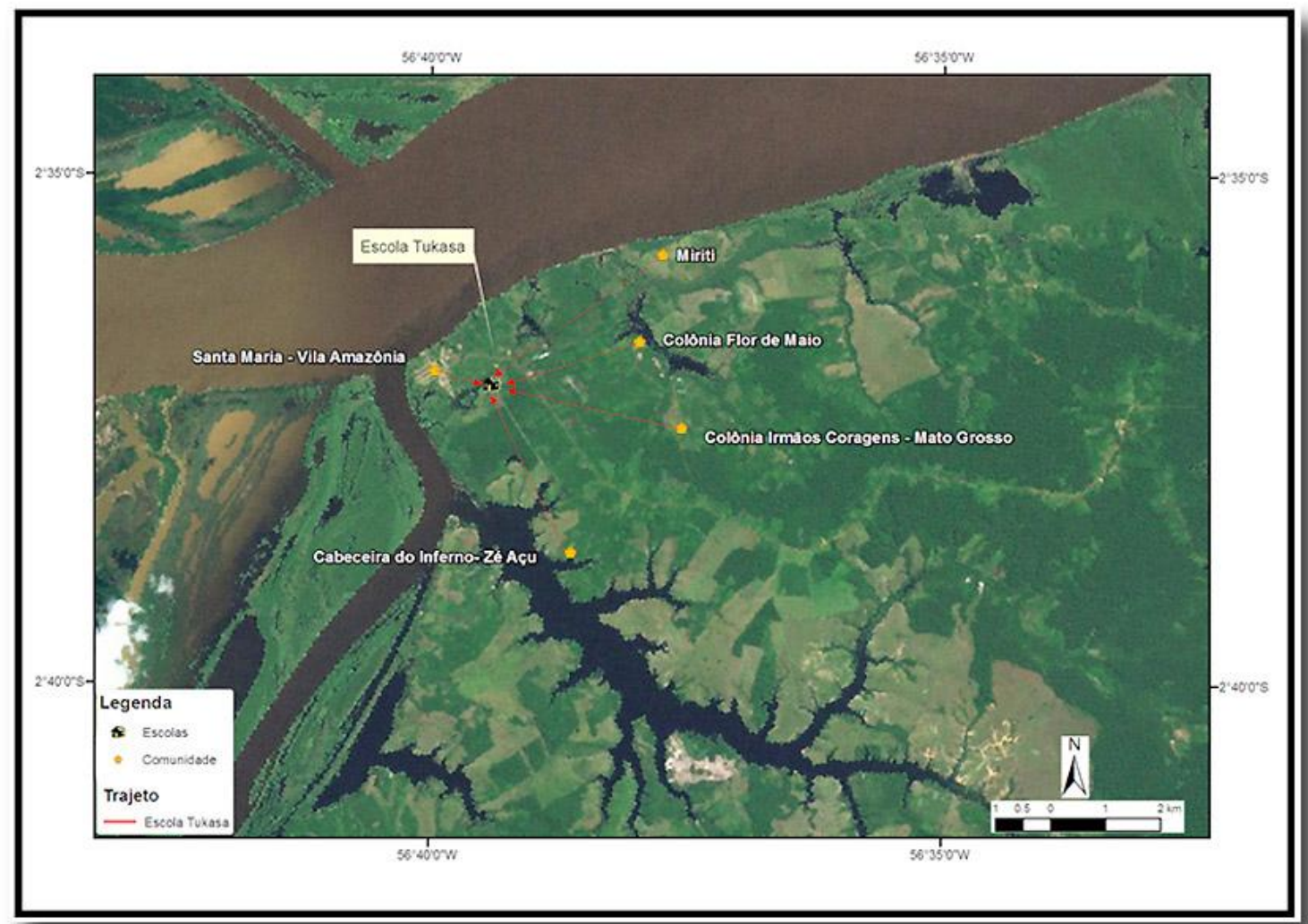

Mapa 5 - Localização das comunidades dos estudantes da Escola Tukasa Uetsuka Organizado por Willer Pinto /Nov/2012

O ensino seriado pode ser reestruturado e, para tanto, necessita de planejamento, discussão e foco nos objetivos pretendidos: uma escola que possa dar resposta ao ribeirinho da água e da terra e floresta, mesmo porque, o impulso na Educação constitui condições essenciais para o desenvolvimento de qualquer lugar. Os esforços direcionam combinações e circunstâncias fundantes para a melhoria do processo educativo nas escolas do município de Parintins, podendo ser projetadas para a Amazônia a partir de programas e projetos de política educacional voltados para o professor aprender e praticar novos métodos ou metodologias para seu trabalho pedagógico educativo, continuamente.

Os professores tem que aprender a planejar suas aulas do ano letivo coletivamente, trocando ideias, aproximando conteúdos e pensando possibilidades de um trabalho mais integrado, mais interdisciplinar, mais intertranscultural, para melhoria e fortalecimento do ensino seriado. Para tanto, o professor, tem que ter voz ativa na construção da proposta curricular do município, porque segundo Romão (2010) os planejadores, os que tomam decisão e apontam os direcionamentos não são os mesmos que executam ou os que realizam o 
que foi decidido. Tem que haver a participação dos sujeitos executores nas decisões, nos planejamentos, para haver uma construção coletiva de um currículo participativo.

Assim sendo, acredita-se em um processo educativo participativo, gerador de desenvolvimento e resultante de produto de forças que atuam na escola e tem seus reflexos positivos do ensino-aprendizagem, onde muitas pessoas são afetadas positivamente e pode haver um processo dinâmico de desenvolvimento socioeconômico das comunidades ribeirinhas. Uma escola sozinha, sem participação dos sujeitos, não participa da vida comunitária e não gera um desenvolvimento estável para o lugar.

\subsection{Ensino multisseriado: uma aprendizagem conturbada}

As complexidades existentes na estrutura do ensino ribeirinho do município de Parintins estão distantes de serem sanadas e as velhas estruturas vão sendo mantidas, como as escolas com as classes multisseriadas. Este sistema, no contexto do ensino brasileiro, já deveria ter sido superado mas ainda é presente nas escolas do interior da Amazônia. Uma das principais razões dessa manutenção está ligada a questão financeira, porque verba para a Educação no Brasil é gasto e não investimento. Então, é mantido um professor ou uma professora para assumir a escola com uma única sala de aula com multisséries.

$\mathrm{Na}$ classe multisseriada o professor é responsável por ministrar entre quatro a seis disciplinas para os estudantes de primeiro ao quinto ano do ensino fundamental. Este herói ou heroína do processo educativo reúne todas as suas energias para conduzir a aula em ritmo que possa atender em grupo ou individualmente os estudantes, tentando realmente ensinar. Os estudantes reunidos em uma única sala de aula são separados em grupos por ano de ensino e esta forma dá uma dinâmica diferente para a realização da aula. A explicação de um determinado conteúdo para o primeiro ano, serve para todos os estudantes, por mais que os de outros anos de ensino permaneçam de cabeça baixa fazendo exercícios. Ocorre o mesmo processo quando é explicado conteúdo para os estudantes do quinto ano de ensino. Todos participam diretamente da aula e os mais avançados tiram proveito porque estão sempre relembrando o que já estudaram. Os que estão iniciando sentem muito mais dificuldades de compreensão do conteúdo ministrado.

Geralmente, os conteúdos são de diferentes disciplinas para cada série, ou seja, não é só língua portuguesa, mas geografia, história, ciência, matemática. O professor-herói ou professora-heroína tem que dar conta de raciocinar de forma diferente quando passa dar 
explicação de um conteúdo para determinada ano, no momento em que encerra a explicação de um conteúdo diferente de outro ano de ensino e de outra disciplina. É complexo, mas é uma das realidades existentes nas escolas das comunidades ribeirinhas amazônicas. Seguindo este raciocínio, Pinheiro (2009, p.39) faz a seguinte afirmação: “A multisseriação segue a mesma lógica da seriação quanto à organização dos conteúdos por série, planejamento, etc. Uma das diferenças se dá na prática do trabalho docente que ao invés de desenvolver o ensino e a aprendizagem para alunos de uma única série, o faz com várias séries no mesmo espaço e ao mesmo tempo".

Esta atenção dada aos cinco anos de ensino ao mesmo tempo vai ser determinante no baixo nível de aprendizagem porque o processo de ensino-aprendizagem das escolas ribeirinhas vai estar comprometido em termos de qualidade. É importante salientar que o professor não é o culpado deste processo, mas a própria estrutura do sistema educacional.

Ressalta-se que a classe multisseriada poderia ser uma grande alternativa para as escolas municipais, caso houvesse um planejamento, como ocorreu na década de 1980, com o Projeto "Educação para o Meio Rural do Amazonas", proposto e implantado pelo Instituto de Educação Rural do Amazonas, que além de contextualizar a realidade local poderia ser uma alavanca de discussão e criticidade sobre a realidade vivida, pelo próprio estudante que passaria a ler e reler sua e outras realidades próximas e distantes, criticando-as. Freitas (2005, p.43) fortalece o raciocínio desenvolvido quando diz que:

\footnotetext{
A educação do campo/classes multisseriadas que queremos, deve ser uma prática fundamental de reinvenção social, onde se possa questionar, construir, desconstruir os dispositivos que são utilizados pelas políticas públicas globalizantes a fim de manter a desigualdade e a exclusão dos que, por medo, não lutam e os que lutam são tombados. Estes são os que nos dão forças para reinventar novas formas de intervenção na educação da Amazônia e, por que não, deste país.
}

São caminhos tortuosos. No primeiro momento, distante de ser alcançado. Mas há possibilidade de trilhar mudanças e fazer acontecer se houver discussão e decisão coletiva, partindo sempre das classes populares, como afirma Romão (2010) para realmente ser o grande suporte das reivindicações para ocorrer melhorias de vida em cada comunidade a partir da escola e da sistematização do conhecimento e sua aplicação nas práticas cotidianas associada ao saber historicamente construído.

O processo de ensino-aprendizagem em classe multisseriada pode representar um processo alternativo de aprendizagem se for criado uma metodologia que facilite o diálogo entre os alunos de anos de ensino diferentes, onde todos possam aprender conjuntamente. Para 
que isso possa acontecer é necessário preparar o professor para trabalhar nessa escola, com multissérie.

Pinheiro (2009), em sua dissertação de mestrado, Currículo e seus significados para os sujeitos de uma escola ribeirinha multisseriada do Município de Cametá, procura apresentar a complexidade da educação multisseriada de Cametá - PA, que não é diferente da de Parintins. Apresenta uma verdadeira descrição de todos os aspectos dos moradores e das crianças que vivem a margem do rio Tocantins, adaptadas ou ciclo da maré e ao mesmo tempo o movimento da água conduz e possibilita as crianças acesso ao saber formal escolar e ao saber não-formal, a partir dos conhecimentos historicamente construídos e revividos e mantidos de geração a geração. As comunidades ribeirinhas de Parintins vivem a sazonalidade do rio Amazonas - cheias e vazantes - e o modo de vida está adaptado a este processo tanto no aspecto produção agrícola quanto a vida escolar. Apresenta a complexidade da escola e de seu currículo, que não atende as reais necessidades do ensino na escola ribeirinha, deixando de lado ou mantendo fora de leitura à realidade vivida por cada estudante, que não consegue ler e discutir seu mundo vivido, percebido, sentido e mais ainda o que mantém dentro de si o seu sentimento de identidade cultural. Após ter feito toda descrição do lugar - casas palafitas, o transporte fluvial, o tempo de viagem - passou a analisar o currículo na perspectiva deste ser o grande guia do conhecimento, abarcador da realidade local, porém, como não é construído como processo escolar, mas imposto pela Secretaria de Educação não tem sentido de processo, mas de guia de conteúdo adotado na escola de Cametá - PA ou que deve ser seguida na escola ribeirinha.

Freitas (2005), no entanto, em sua dissertação de mestrado - O ensino de Ciências em Escolas Multisseriadas na Amazônia ribeirinha: um estudo de caso no Estado do Pará - faz uma abordagem panorâmica sobre a realidade das escolas ribeirinhas no município de Belém - Pará, destacando o ensino em classe multisseriada. Apresenta, com base em suas pesquisas, os problemas vivenciados pelas professoras na árdua profissão de ensinar e as dificuldades vividas pelos alunos no processo de aprender. Na mesma linha de questionamento abre espaço para lançar crítica aos programas e proposta do governo federal que não contempla a Amazônia em sua multiplicidade e complexidade sociocultural e socioambiental educativa, ou por desconhecimento ou simplesmente por não ter desenvolvido uma política educacional que atenda a heterogeneidade do Brasil e em particular da Amazônia, mas trabalhando sempre na perspectiva da homogeneização educacional. Apresenta sabiamente as dificuldades vividas por professores que se dedicam ensinar e educar para a vida as crianças do rio e da floresta 
diante de todas as condições obstaculizantes para um ensino-aprendizagem significativo. Porém, ninguém desiste, mas insiste na vontade de fazer diferente e contribuir com as mudanças.

As duas realidades do Estado do Pará são idênticas à realidade de Parintins e de outras realidades do estado do Amazonas no tocante a classe multisseriada e ao processo educativo. A única diferença existente é que em Parintins as classes multisseriadas não estão mais somente no fundamental de primeiro ao quinto ano, isto é, já se estendeu para o fundamental de sexto ao nono ano. Este último tema vai ser tratado no item ensino modular.

Cinthya da Cruz Martins, em sua dissertação de mestrado - Espacialidade e saber: $a$ nucleação das escolas rurais de Nova Olinda do Norte - Amazonas - navega analisando a dinâmica da educação ribeirinha deste município na tentativa de compreender as singularidades e as particularidades existentes como determinantes regionais importantes mas não vista pelo currículo adotado. Procura retratar o modo de vida dos moradores da beira do rio que aprendem com este e constroem saberes que lhes ajudam a viver e utilizar com racionalidade os recursos naturais, ou seja, plantando na várzea ou pescando nos lagos, os quais se traduzem em temporalidades e espacialidades dentro do município de Nova Olinda do Norte, dentro do Amazonas e Amazônia. Para melhor entender e contribuir com a leitura do ensino ou da educação das escolas ribeirinhas de Nova Olinda do Norte - localizada no Rio Madeira - que é uma contribuição para entender a educação do interior da Amazônia, Cinthya desenvolveu o estudo em dois Polos: I- Lugar Machurinin, Comunidade Santa Fé e Costa do São Domingos (área de várzea) e II - Vila São João, Comunidade Boa Fé e Lago do Moura (área de terra firme), lugares herdados de ancestralidades indígenas e marcas dos colonizadores. Vidas foram ceifadas, sangue manchou o solo, a água tingida ficou e o espaço amazônico foi tomado e transformado pela vontade de seus habitantes pretéritos e atuais, registrado nas páginas do tempo histórico. Outro aspecto importante é a análise feita sobre as políticas públicas educacionais implantadas a partir da Lei de Diretrizes e Base 9.394/1996: projetos educacionais, mudanças nas propostas de ensino, as quais exigem adaptações dos integrantes do processo educacional das escolas de várzea e terra firme. Os sujeitos mais interessados não participaram das discussões para as mudanças implantadas onde seus anseios escolares, suas lutas, a história de seu lugar de vida, nada da realidade local foi respeitada pelos projetos implantados. Isto não é política publica mas política de governo. A escola e a educação deste município são iguais as do Pará e também de Parintins, com núcleo de ensino, 
classe seriada, classe multisseriada, problemas sociais, econômicos diversos e educacionais lembrados apenas em tempos de campanha política partidária.

O diálogo sobre classe multisseriada abre espaço de visualização inter e transcultural, não como modelo, mas como alternativa ou proposta de desenvolvimento a partir da própria escola no momento em que forem adotadas ações de organização e participação de todos os sujeitos integrantes e responsáveis pela comunidade, pois a luta deverá ser em prol de uma escola mais cidadã e mais integrada, procurando soluções para a falta de recursos e apoio didático (necessitando cursos contínuos aos professores), apoio de orientação pedagógica para uma adequação do ensino das escolas ribeirinhas amazônicas.

A escola tem que ser espaço aberto de diálogo, de construção e fortalecimento de relações socioeducativas e sociocultural, dentro de contextos socioambientais e socioeconômicos, para continuar existindo como meio articulador de desenvolvimento intelectual e voltado para ler e tecer crítica à realidade local, para ter e manter sua presença de espaço dialógico e de produção de saber, para ser o elo fortalecedor de todas as relações comunitárias, pois, segundo Gadotti (2008, p. 93) a escola sendo o "espaço de relações" mantém na sua história de construção de cidadãos dinâmicos e ávidos por mudanças, o sentido de serem altamente críticos e exercitando sua criatividade, para deixar o lugar - escola - cheio de representações sociais.

\footnotetext{
A escola não é só um lugar para estudar, mas para se encontrar, conversar, confrontar-se com o outro, discutir, fazer política. Deve gerar insatisfação com o já dito, o já sabido, o já estabelecido. Só é harmoniosa a escola autoritária. A escola não é só um espaço físico. É, acima de tudo, um modo de ser, de ver. Ela se define pelas relações sociais que desenvolve. E se ela quiser sobreviver como instituição, no século 21, precisa buscar o que é específico dela numa sociedade de redes e de movimentos que é a sociedade atual. A escola não pode mudar tudo e nem pode mudar a si mesma sozinha. Ela está intimamente ligada à sociedade que a mantém. Ela é, ao mesmo tempo, fator e produto da sociedade. Como instituição social, ela depende da sociedade e, para mudar-se, depende também da relação que mantém com outras escolas, com as famílias, aprendendo em rede com elas, estabelecendo alianças com a sociedade, com a população. (grifo do autor).
}

Essa escola é constituída por professores, estudantes, pais de estudantes, comunitários e demais sujeitos participantes das construções das múltiplas relações sociais fortalecedoras do sentimento de pertencimento e valorização do lugar de vida.

Os professores das escolas ribeirinhas de Parintins não ficam por muito tempo na mesma escola. A Secretaria de Educação faz o remanejamento para que o professor não crie vínculo com a comunidade, refletindo como estratégia de política partidária para que este não 
possa trabalhar o processo educativo politizador e que venha dar autonomia de pensar e agir aos comunitários. Além destes aspectos descritos e da situação complexa da classe multisseriada, o professor(a) da escola ribeirinha de Parintins enfrenta problema de moradia, porque não há nenhuma casa construída para ele ou ela residir, e, muita das vezes, vive em casa dos comunitários, sem muita privacidade.

Outro desafio do professor é o ato de ensinar porque tem que planejar suas aulas e não sobra tempo de pescar seu alimento. Por isso fica na dependência do comunitário de lhe fornecer o alimento do almoço e do jantar. Assim, tem de encontrar condições viáveis para ensinar e fazer com que os alunos se sintam em um lugar de liberdade, porque são possuidores de liberdade (figura 23), assim expressada por uma estudante da escola Tiradentes, da comunidade Menino Deus, do Itaboraí do Meio, quando lhe foi perguntado se gostaria de ir morar na cidade e lá estudar:

"Eu gosto de morar aqui na comunidade. Aqui eu tenho liberdade de andar de canoa. Tenho liberdade para ir tirar o peixe da malhadeira. Tenho liberdade de pular n'água, de correr na beira do rio, de ir buscar o gado para o curral. Na cidade... eu já fui lá, mas não posso sair para a rua, por causa do perigo. Se for sair de casa tenho que sair acompanhada. Quase todo tempo presa em casa." (estudante do sexto ano do ensino fundamental - 12 anos).

A liberdade é construída na relação de confiança na comunidade, entre pais e filhos, e na responsabilidade assumida pela criança na execução de pequenas atividades, no momento em que seus pais estão trabalhando na produção agrícola ou na pescaria. 


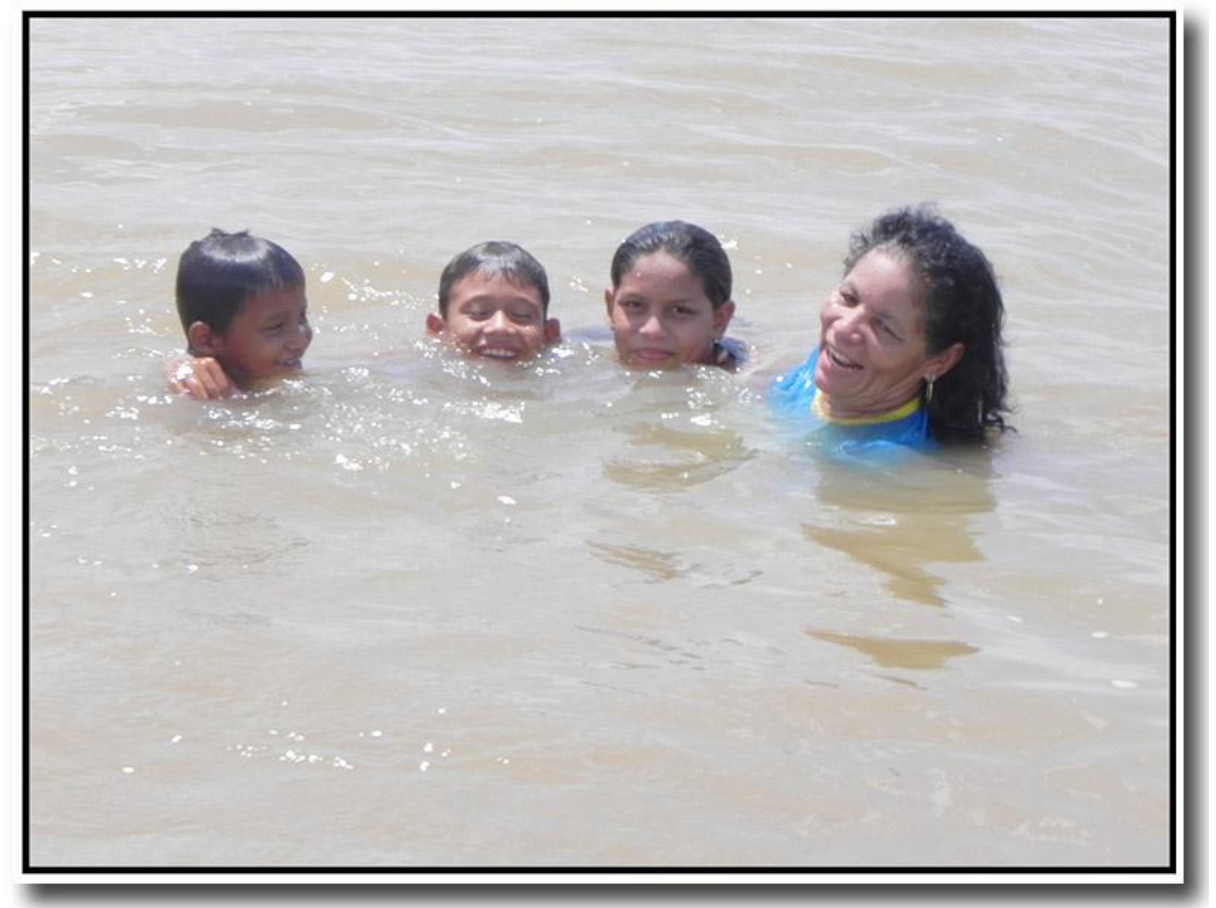

Figura 23 - crianças tomando banho, com a gestora da escola, antes do almoço e da aula. Foto: Camilo Ramos - outubro/2011

Há alegria nesta escola e vontade de construir conhecimentos dentro das possibilidades existentes. E assim é mantida viva a alegria de aprender porque o ser infantil existente dentro de cada professor está presente em cada sala de aula representado pelos estudantes ávidos e sedentos de aprendizagem, como questiona e ensina Gadotti (2008, p.9798):

O professor precisa saber muitas coisas para ensinar. Mas o mais importante não é o que é preciso saber para ensinar, mas como devemos ser para ensinar. O essencial é não matar a criança que existe dentro de nós. Matá-la seria uma forma de matar o aluno que está a nossa frente. $\mathrm{O}$ aluno só aprenderá quando tiver um projeto de vida e sentir prazer no que está aprendendo. $\mathrm{O}$ aluno quer saber, mas nem sempre quer aprender o que lhe é ensinado. Devemos aprender com a rebeldia do aluno, que é um sinal de sua vitalidade, um sinal de sua inteligência e de seu desejo de aprender. Ela deve ser canalizada para a criatividade social e não para a violência. (grifo do autor).

Foi possível perceber na Escola Tiradentes o envolvimento dos professores e alunos durante a aula como em momentos fora do horário de aula. Da participação ativa nas atividades propostas, indo do capinar o campo de futebol até o momento de plantar na pequena horta escolar suspensa (balcão suspenso por causa da enchente - produz tanto na vazante quanto na enchente - figura 24). 


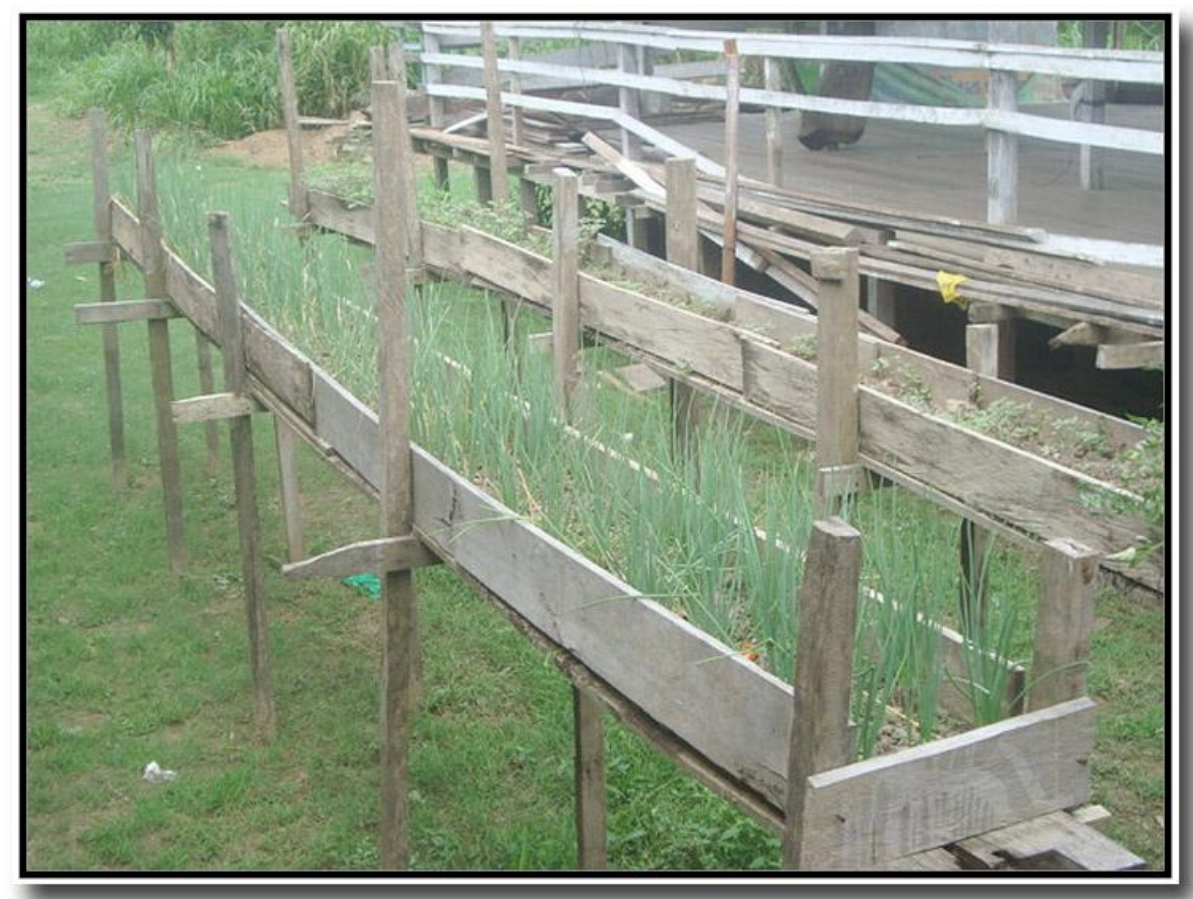

Figura 24 - Balcão suspenso por causa da enchente - horta da Escola Tiradentes Foto: Camilo Ramos - outubro de 2011

Considerando a diversidade de elementos existentes na escola de várzea o ensino multisseriado, poderia a ser chave para os estudantes de anos de ensinos diferentes. Terem momentos para dialogar e aprender a partir do que fazem e como fazem. Infelizmente, o ensino ainda está moldado no que foi estabelecido em tempos pretéritos e ainda não houve proposta de mudanças.

Mudança foi feita no calendário da várzea, que ocorreu na década 1980, acompanhando a sazonalidade do rio Amazonas, ou seja, tem seu início em agosto e seu término final de abril. Esta mudança atende o que determina a Lei de Diretrizes e Base 9.394/1996 - em seu Capítulo II - Da Educação Básica -, Seção I - Das Disposições Gerais, Art. 22, no $\S 2^{\circ}$ “ $O$ calendário escolar deverá adequar-se às peculiaridades locais, inclusive climáticas e econômicas, a critério do respectivo sistema de ensino, sem com isso reduzir o número de horas letivas previsto nesta lei". Esta adequação, antes da lei, foi feita porque os pais tiravam os filhos da escola para que pudessem ajudar na colheita, antes que a água cobrisse a várzea e assim tivessem prejuízos. Dessa forma, os estudantes não tiveram que abandonar a escola porque ajudam aos pais a plantar em julho e colher a produção em janeiro e fevereiro, sem que tenham perdas escolares. 
As perdas estão na organização do ensino multisseriado, que passou a ser chamado de agregados, comportando a educação infantil e de primeiro ao quinto ano. Continua o mesmo sistema da classe multisseriada. Poderiam ocorrer mudanças significativas se a educação fosse vista como investimento e não como gasto. Investimento no planejamento coletivo voltado para o trabalho em classe multisseriada como também a equipe de pesquisadores em constante diálogo com professores e alunos. Com isto, poderia surgir os meios possíveis para elevar a qualidade do ensino neste sistema existente nas escolas ribeirinhas. É importante destacar que os professores que compõem o quadro da Escola Tiradentes possuem nível superior (ou estão cursando), mas não estão preparados para trabalhar com esta forma de ensino e muito menos para assumirem disciplinas diversificadas e distantes de sua formação.

A classe multisseriada exige um professor que possa dominar multiconteúdo. Assim o professor tem que saber se nivelar para dialogar com alunos de diferentes níveis de ensino: $1^{\circ}$, $2^{\circ}, 3^{\circ}, 4^{\circ}$ e $5^{\circ}$ ano. Foi possível observar o uso da mesma linguagem para se comunicar com alunos de todos os níveis. Este professor, atuante neste tipo de turma, traz dentro si um super profissional porque é um professor multidisciplinar, não que seja preparado para atuar com multidisciplinas mas pela imposição do sistema educacional vigente nas escolas das comunidades ribeirinhas amazônicas. A lógica capitalista de exploração se apresenta em todos os sentidos do trabalho do professor da escola ribeirinha amazônica. Fica muito mais evidente quando o professor assume sem questionar, pela necessidade do salário, turmas estruturadas para a contratação de um único profissional da educação.

Seguindo a discussão e analisando as múltiplas possibilidades da classe multisseriada se tornar o elemento primordial na junção dos conhecimentos formais, com os conhecimentos historicamente construídos ou tradicionais e com o cotidiano, porque deixaria fluir diálogo entre professor e estudante, estudante de níveis diferentes em uma mútua relação de troca de saberes, diálogo com os pais em sala de aula formando um todo de aprendizagem, onde as disciplinas estariam interdisciplinarmente integradas e constituindo bases sólidas para a comunicação de saberes. Nesta sequência de pensamento se encontra a visão instigante de Freitas (2005, p. 46)

As vivências e os conhecimentos dos alunos e da professora de classes multisseriadas, tornam-se saberes e conhecimentos diferentes em interações sociais mediadas em sala de aula, que juntos podem ensinar e aprender interativamente. O sujeito desenvolve suas aprendizagens mediado/orientado pelo adulto (na escola pelo professor) e em cooperação com seus colegas mais capazes. O desenvolvimento da criança, então, está atrelado ao outro, às suas interações sociais. Este é o grande desafio para se trabalhar com as classes multisseriadas, uma vez que nem sempre todas as crianças interagem entre si. A própria organização da sala de aula os 
diferencia em suas séries e o mais agravante é que os alunos da $4^{\mathrm{a}}$ série, em muitas ocasiões, por já haverem desenvolvido certa habilidade com a leitura e a escrita, acabam inibindo que os mais pequenos exercitem suas. (grifo nosso).

$\mathrm{Na}$ estruturação existente da classe multisseriada não se observou este elo de comunicação entre os estudantes como forma de aprendizagem, mas pairava um verdadeiro silêncio na sala, porque o saber está todo concentrado na pessoa do professor. A proposta de Freitas é importante e instigante. Para se chegar a este nível de trabalho educativo é necessário ter um planejamento sistemático para estruturar as mudanças e o professor exerça a função, também, de pesquisador.

Muitos são os caminhos a serem seguidos para as mudanças nas escolas e no processo ensino-aprendizagem para obter qualidade no que é ensinado e como é aprendido. Tudo vai depender da forma como se planeja as aulas ou como pode ser reestruturado o currículo atual. Mudanças são precisas e necessárias para que a escola possa exercer e ser o suporte estruturante do desenvolvimento socioeconômico comunitário.

Tudo que está sendo apresentado e discutido faz parte da geografia existente na escola da comunidade ribeirinha amazônica, mas não está inserido na proposta curricular. Isto tudo poderia compor o corpo de conteúdo e, além disso, tornaria mais e mais rico a aprendizagem, fugindo de modelos e da uniformização do ensino ribeirinho, seja de várzea ou de terra firme.

\subsection{Ensino Modular: uma nova proposta para a escola de várzea de Parintins}

Navegando nas ondas da educação e ancorando no último aspecto da estrutura do ensino das escolas ribeirinhas amazônicas e, principalmente, na Escola Tiradentes - realidade instigante porque o ensino modular foi multisseriado e seriado no fundamental de sexto ao nono ano. Esta estruturação advém da imposição da Secretaria de Educação quando faz

funcionar a escola com apenas quatro professores para trabalharem entre nove a dez disciplinas.

A estrutura disciplinar no ano letivo de 2008/2009, segundo os professores, dificultava o trabalho porque tinha sala de aula que passava a ter dois tempos seguidos da mesma disciplina para poder trabalhar cinco tempos diários, assim exemplificados: $1^{\circ}$ tempo $=6^{\circ}$ ano; $2^{\circ}$ tempo $=7^{\circ}$ ano $; 3^{\circ}$ tempo $=8^{\circ}$ ano $; 4^{\circ}$ e $5^{\circ}$ tempo $=9^{\circ}$ ano. 
Esta estrutura passa a ser substituída no ano letivo seguinte 2009/2010, por blocos de disciplina, sendo estruturado pela Secretaria Municipal de Educação e enviado à escola para ser adotado e colocado em prática, sem a participação dos professores no planejamento e sim só na execução.

$\mathbf{1}^{\mathbf{0}}$ Bloco = Matemática e Língua Portuguesa

$\mathbf{2}^{\mathbf{0}}$ Bloco $=$ Ciências e Geografia

$\mathbf{3}^{\circ}$ Bloco $=$ História e Artes

$4^{0}$ Bloco = Inglês, Educação Física e Religião

A escola faz a distribuição dos blocos para que os professores possam ministrar aula, sendo: os três primeiros tempos para uma disciplina e para um único ano (exemplo $-8^{\circ}$ ano) e dois últimos tempos para a outra disciplina e o outro ano de ensino (exemplo $-9^{\circ}$ ano). No dia seguinte as disciplinas do $9^{\circ}$ ano passam ter três tempos e as do $8^{\circ}$ ano passam para dois tempos. Este mesmo padrão se repete no $6^{\circ}$ e $7^{\circ}$ anos. Sempre trabalhando com o equilíbrio do tempo e assim mantendo a regularidade dos conteúdos.

Estes blocos de disciplinas seguem a seguinte distribuição por meses do ano letivo:

$\mathbf{1}^{\mathbf{0}}$ Bloco = Matemática e Língua Portuguesa: agosto e setembro e parte de outubro

$\mathbf{2}^{\circ}$ Bloco $=$ Ciências e Geografia: outubro e novembro e parte de dezembro

$3^{\mathbf{0}}$ Bloco $=$ História e Artes: dezembro e janeiro e parte fevereiro

$4^{0}$ Bloco = Inglês, Educação Física e Religião: fevereiro e março e mais abril

As informações aqui colocadas, estão de acordo com as recebidas na escola, quando se dialogou sobre este arranjo para que os professores pudessem trabalhar as disciplinas sem problema, acúmulo ou sobrecarga. É importante frisar que a aula se estende até o mês de Abril, dependo do tipo de enchente. Se for uma enchente dentro da normalidade, a aula vai até Abril e se necessário até Maio. Mas se for uma enchente grande, a aula encerra em Fevereiro ou Março, por causa da submersão do assoalho do prédio escolar.

Nessa distribuição por mês estão inseridas todas as atividades socioculturais da escola e da comunidade bem como as datas comemorativas e os feriados, incluindo Natal e Ano Novo.

Quando questionados sobre a nova forma - blocos de disciplina - que substituiu a forma de ensino disciplinar diária por tempo de aula, obteve-se a seguinte resposta dos professores: 
"Trabalhar por bloco foi melhor do que trabalhar por disciplinas diversas, porque fica, o aluno, preocupado em estudar somente as duas disciplinas por bloco".

Considerando o envolvimento do estudante em dois meses de aula em duas disciplinas, emergiu os seguintes questionamentos:

- Como perceber que o aluno aprendeu o que foi ensinado do bloco passado para o bloco seguinte das disciplinas?

Pelo que foi percebido, não há um acompanhamento sistemático no ano letivo seguinte para saber o que realmente o estudante aprendeu e fica caracterizado como não houvesse uma sequência lógica entre o conteúdo de um ano de ensino ( $6^{\circ}$ ano) para com o outro $\left(7^{\circ}\right.$ ano), ou seja, como se os conteúdos só servissem para aquele ano de ensino estudado e não sua continuidade educacional no ano de ensino seguinte. Ainda é preciso fazer um acompanhamento mais estruturado para realmente saber o grau de aprendizagem dos conteúdos.

- Como saber se o aluno domina o conteúdo de todos os blocos no final do período letivo?

Este questionamento está relacionado ao primeiro. Novamente vai de encontro com a necessidade de se fazer um acompanhamento mais sistematizado para saber se houve ou não aprendizagem dos conteúdos necessários a sua construção de vida social ou profissional futura. Pelo que foi observado nas aulas e no processo ensino-aprendizagem, principalmente a aprendizagem, tudo fica muito estanque, parado, como se não necessitasse dar continuidade ao estudo. Não foi possível visualizar a aplicação do que foi estudado pelos estudantes no seu fazer diário. Alguns estudantes foram observados nos trabalhos que realizam e em nenhum momento foi notada a utilização do conteúdo estudado na escola. Em relação à geografia não foi visto o uso dos conhecimentos, mesmo estando próximo da erosão fluvial junto à suas casas, o transporte escolar e os inúmeros meios de transporte que passam pelo rio Amazonas em frente às suas casas, conduzindo pessoas, mercadorias, ou seja, transportando relações socioculturais e socioeconômicas e outros aspectos geográficos que não são compreendidos, mas fazem parte da vida cotidiana de cada estudante. 
- O aluno conhece o lugar que estuda? Qual o sentido de conhecer?

Pode-se dizer que os estudantes conhecem o seu lugar de vida e de estudo e por conhecerem passam a valorizar porque nutrem sentimentos de pertencimento e valorizam o seu modo de vida comunitária.

Estas respostas ainda não são suficientes para dar conta de um todo existente nas relações escolares e nas relações comunitárias mas, segundo as professoras, toda estrutura de ensino por bloco de disciplina é positiva e os alunos gostaram mais dessa forma de estudar porque - como também é para as professoras - a preocupação dentro de dois meses é apenas com duas disciplinas.

O importante não é o que se ensina sim como se ensina para que passe a ter valor de vida, dando sentido ao que se quer ou que se está aprendendo.

Quando este subsistema estruturante da aula foi implantado a distribuição por professores ficou assim configurado:

\section{Professora Nelcélia: $8^{\circ}$ e $9^{\circ}$ ano}

Trabalhando Ciências e Matemática.

Formação acadêmica: Ciências Naturais.

\section{Professora Sônia: $8^{\circ}$ e $9^{\circ}$ ano}

Trabalhando Língua Portuguesa, Geografia, História e Inglês.

Formação acadêmica: Pedagogia.

\section{Professor Moisés: $6^{\circ}$ e $7^{\circ}$ ano}

Trabalhando Geografia, Língua Portuguesa, História e Inglês

Formação acadêmica: História.

\section{Professora Rosa: $6^{\circ}$ e $7^{\circ}$ ano}

Trabalhando com Matemática e Ciência

Cursando Pedagogia.

Considerando a formação dos professores e as disciplinas que ministram, passam encontrar muitas dificuldades para desenvolver um bom trabalho no processo ensinoaprendizagem. É importante destacar o esforço e o empenho de cada professor no ato de ensinar. No processo de observação, foi possível perceber que mesmo sem ter o conhecimento vertical sobre determinada disciplina, há o empenho em passar com clareza, dentro das limitações, os conteúdos ensinados. 
Esse arranjo na educação é que deixa cada vez mais o ensino com menos qualidade e também deixa os estudantes com a aprendizagem comprometida e com o conhecimento fragmentado. Nessa luta vale o esforço de todos e também de cada um no sentido de ampliar e fortalecer os conteúdos estudados e aprendidos.

O agente principal deste processo educativo não foi levado em consideração e tomado como principio de desenvolvimento escolar: o estudante. Seria muito importante construir bases teóricas para a estruturação de um subsistema educacional adequado às necessidades, aspirações e valores existentes no lugar para se chegar à transformação da realidade socioeconômica, sociocultural, socioambiental e as relações estabelecidas diariamente.

Nesse contexto, a escola poderia promover a participação e a organização mais efetiva dos membros comunitários porque neles se encontra o suporte das ações reivindicatórias no sentido de procurar a melhoria do ensino para se chegar à melhoria de vida e, desta forma, contribuir com a melhoria da economia dos pequenos agricultores e criadores que são os próprios comunitários. Assim, estaria edificando uma escola que tivesse sentido de existência na comunidade e não uma escola que promova o êxodo dos estudantes para a cidade. Jacobi (2006, p. 18) ao prefaciar o livro A educação rural no Brasil: o caso da Escola do Campo no Paraná, tece a seguinte argumentação:

\footnotetext{
Por que o jovem que nasce e se cria no ambiente rural deseja desesperadamente buscar uma nova vida fora desse ambiente? Certamente a resposta está na falta de uma educação que o eduque para sua realidade, para o seu desenvolvimento, para que veja novas perspectivas para sua vida e de sua família. Parece haver um grande descompasso entre seus desejos e reais necessidades, e os instrumentos que a sociedade the oferece através da educação. Por que então esta permanente insistência na uniformização dos modelos? Talvez possamos explicar pela origem dos profissionais que trabalham na zona rural. A maioria tem a sua formação focada na realidade urbana que é onde reside e se identifica. As pesquisas sobre novos métodos, novas abordagens, novas tecnologias, novas estruturas curriculares não têm contemplado a educação como uma estratégia de desenvolvimento, regionalizado, localizado e sustentável, social, econômica e ambientalmente. Pelo contrário, insiste em ser um modelo de educação linear, um produto padronizado para facilitar sua produção.
}

Estes questionamentos e suas respostas sintetizam o que já foi questionado e analisado sobre a educação e o ensino das escolas ribeirinhas de Parintins. Por isso, acredita-se na necessidade de romper com a estrutura estabelecida ao ensino ribeirinho, para conduzir à estruturação intelectual deixando-o preparado para estudar tanto na cidade de Parintins quanto em outro lugar do Brasil. Ousar em fazer diferente e apresentar propostas de discussões para alterar esta estrutura seriada, multisseriada ou de bloco de disciplina e modular, dando voz e permitindo a fala dos sujeitos aprendentes juntamente ouvindo os pais para saber que tipo de 
escola que preferem para seus filhos, porque são conhecedores de sua realidade, onde carecem de reflexões sobre condições sociais e econômicas.

A escola ribeirinha não pode ser apenas uma receptora e executora de ações pensadas e planejadas na visão urbana e distante de sua realidade. Tem que haver processo de discussão na escola e o resultado deverá ser encaminhado a Secretaria de Educação, que após discutir com seu quadro técnico promoveria uma assembleia no sentido de discutir mudanças na estrutura do ensino a partir dos movimentos sociais organizados ou base popular, onde sejam estabelecidos Projetos e Programas de abrangência de desenvolvimento socioeducativo para se chegar a um desenvolvimento socioeconômico e assim estabelecer a valorização do trabalho dos ribeirinhos.

Se não há produção no campo, a cidade não se alimenta e a indústria não transforma. Isto para entender que a cidade depende do campo e, se o campo não for valorizado a partir da produção familiar, a cidade sofrerá as consequências. Valorizar o trabalho do campo é valorizar o sujeito produtor e assim também trabalhar a valorização da escola e do ensino na oferta de condições de crescimento e melhoria educativa e intelectual dos sujeitos aprendentes.

A estrutura escolar da maneira que está estabelecida, atende somente um fim que é a dominação e controle, não permitindo diálogo e mudanças, para que o tipo de governança se mantenha dominando, conforme afirmação de Pacheco Júnior e Torres (2009, p.9):

Este contexto expressa a negação estrutural das possibilidades do ser mais e a
vocação humanizadora dos indivíduos: práticas educacionais bancárias que refletem
uma estrutura de poder e dominação que domestica e inibe a criatividade, que
desconhece homens e mulheres como seres históricos; ações antidialógicas que
mitificam, dividem, manipulam e invadem culturalmente a classe e os oprimidos;
remodelamento da realidade de acordo com a ideologia dominante com vistas à
manutenção da estrutura de poder. Nessa conjuntura fortemente marcada por tais
contradções, as práticas em Educação Popular refletem a necessidade da
organização da classe trabalhadora para superação das contradições históricas mais
latentes, contribuindo com a construção de um novo mundo possível. (grifo dos
autores)

Esta discussão conduz a pensar sobre os objetivos da escola na comunidade ribeirinha - porque ainda não conseguiu romper os laços herdados do provincianismo e da manutenção da situação de controle - quando não propõe uma escola participativa e cidadã. A escola deve ser estimuladora de mudanças que se fazem necessárias para a implantação de propostas inovadoras que atendam às aspirações e necessidades do lugar, promovendo perspectivas de vida diferente aos estudantes e aos pais dos estudantes. Não que se esteja pensando em encher 
a escola de responsabilidade, mas uma escola cidadã tem que ser presente e fomentadora de mudanças estruturais.

Deve haver articulação com os diversos setores da área social e econômica, no sentido de formar parceria para desenvolver ações integradas junto aos comunitários como processo de formação e de desenvolvimento comunitário e assim manter todos como sujeitos ativos dentro do processo de mudança escola-comunidade.

Esta forma de ensino modular, engessa e prende o professor em sua docência como mero repassador de conteúdos contidos em livros didáticos, obedecendo ao estabelecido pela Secretaria de Educação e não permitindo realizar possíveis mudanças necessárias porque vai ser cobrado quando da visita do quadro de orientadores pedagógicos pelo não cumprimento da aplicação dos conteúdos contidos na proposta curricular de ensino. Nesta luta de interesses, os professores abafam suas inquietações, suas vontades, seus projetos de mudanças e seus objetivos e sonhos de uma escola mais integradora e mais cidadã. Sonhos de crescimento e aperfeiçoamento intelectual. Nos diálogos formados, durante a pesquisa, a professora de Geografia solicitava auxílio porque não dominava os conteúdos, principalmente na parte cartográfica. E isto levou a pensar uma oficina que facilitasse a comunicação de ensino professora-aluno. Foi mostrado o processo interdisciplinar para trabalhar coordenadas geográficas juntamente com a matemática nas coordenadas cartesianas. Para ficar compreensivo, foram utilizadas as frestas do assoalho para determinar as linhas imaginárias dos meridianos e os paralelos que foram definidos com barbante. Após a montagem das linhas imaginárias foi mostrado como fazer a localização, utilizando objetos da comunidade e os próprios alunos (figura 25) como elementos ou pontos marcadores no globo e como deveriam visualizar as coordenadas geográficas e as coordenadas cartesianas. 


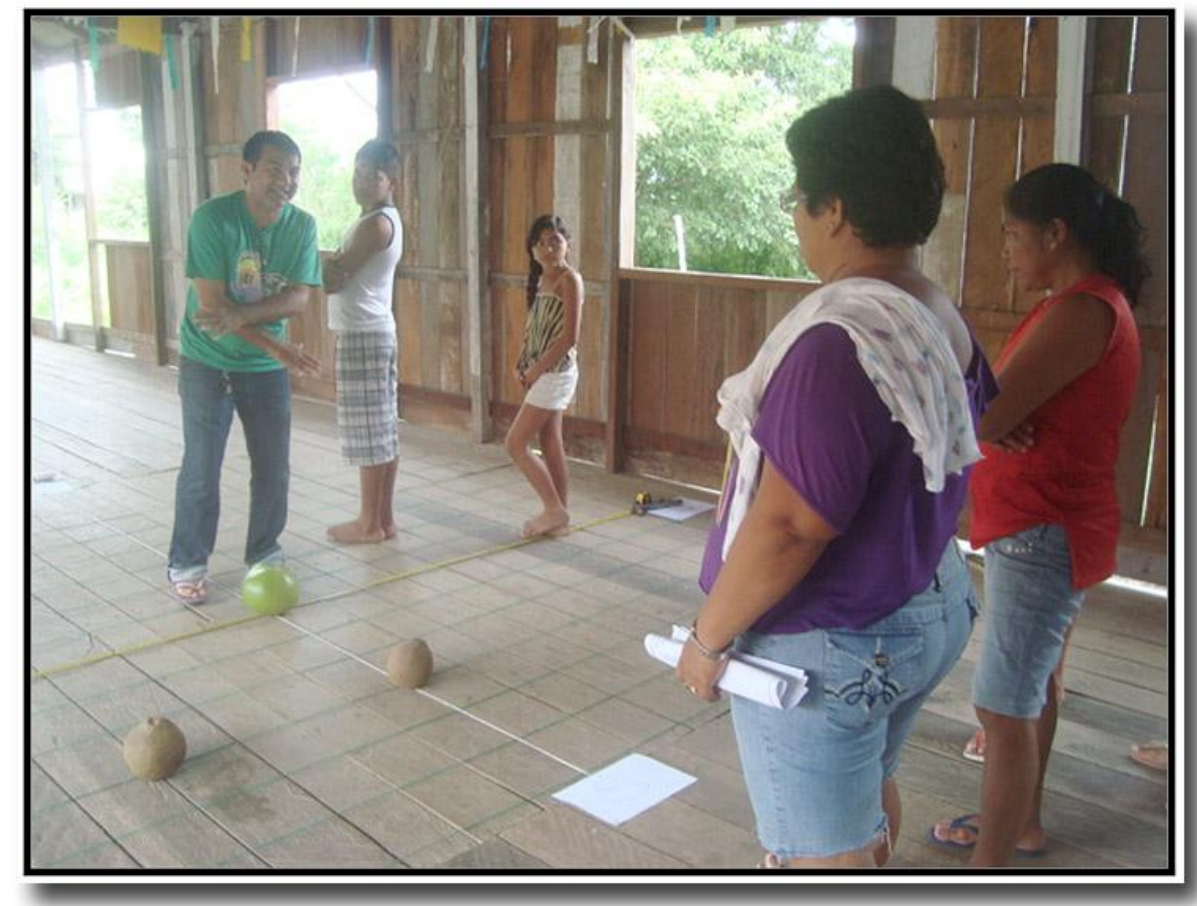

Figura 25 - Explicação de coordenada geográfica no piso Foto: Camilo Ramos - outubro/2011

A proposta da atividade não era ensinar conteúdo e muito menos passar um modelo ou uma receita, o pretendido foi aflorar a criatividade das professoras e também mostrar como se trabalhar de forma interdisciplinar.

Isso deixa evidente que o ensino cristalizado não permite a criatividade de construir possibilidades de ensinar e nem de facilitar a compreensão do estudante do conteúdo trabalhado. Não permite ao professor ver e criar os recursos didáticos a partir dos recursos naturais existentes na comunidade. Esta forma prática de ensinar, demonstrada na oficina, conduz a questionamentos de ordem sociocultural, socioeconômica e socioambiental, questionando a estrutura de ensino estabelecida e mexe com a vontade dos sujeitos por mudanças e melhoria do ensino para a comunidade.

Há inúmeras geografias na comunidade. Enquanto não for rompida esta estrutura que molda a escola, será muito difícil aproveitar os recursos naturais para ensinar e aprender e conduzir os estudantes a perceber que caminham e navegam em lições geográficas, em conteúdos da geografia nas múltiplas relações humanas e físicas e nas suas jornadas diárias ou cotidianas - e que estão utilizando saberes geográficos aprendidos com seus pais - e não conseguem associar os conhecimentos geográficos aprendidos na escola com seus afazeres domésticos e nos trabalhos da agricultura, criação ou nas práticas extrativistas da pesca. 
A Geografia se faz presentes nas histórias de visagem, na crendice da cobra grandecausadora do fenômeno terras-caídas, nas entidades protetoras do rio (iara) e da floresta (curupira, juma, mapinguari, jurupari). Um universo de conhecimento a ser explorado nas salas de aulas que podem ser associados aos conteúdos ministrados, porque nessas relações socioculturais e de vida ribeirinha de várzea e de terra firme há espaço geográfico e muitas territorialidades.

A Geografia nesta estrutura modular - e as outras disciplinas - ficam apenas nas informações contidas nos livros didáticos e não transpondo as paredes para olhar o todo geográfico existente na comunidade e no seu entorno. Com isso os estudantes não conseguem olhar o seu lugar de vida e perceber como a Geografia se faz presente e se apresenta em sua vida.

Assim sendo, as discussões demonstram que a estrutura do ensino atual não dá resposta às ansiedades ribeirinhas e nem à todas as escolas de todos os lugares, por não alargar horizontes no que concerne aos Programas e Projetos e ainda não se vislumbra uma política de valorização dos professores através de cursos regulares para obtenção de base teórica sólida - já que o professor é multidisciplinar, tendo que dar conta de disciplina completamente fora da sua área abrangência de conhecimento. 


\section{CAPÍTULO 4 - GEOGRAFIA E CARTOGRAFIA NAS ESCOLAS DAS COMUNIDADES RIBEIRINHAS DO MUNICÍPIO DE PARINTINS}

As experiências vividas na beira do rio são traduzidas em conhecimento a partir do tempo em que se passou navegando e balançado pelos banzeiros (ondas grandes do rio Amazonas), indo ao encontro de respostas a questionamentos sobre a Geografia nas Escolas das Comunidades Ribeirinhas. Em cada percurso, a exuberante floresta de várzea ou de terra firme observa silenciosamente o navegador, pois são muitos os que passam indo para seus lares, para pesquisar e outros vão à procura de seus alimentos nos lagos. Suavemente movimentadas pela brisa, as árvores balançam como um "até logo mais" ou uma despedida como se fossem braços levantados e as mãos espalmadas em sinal de um "até breve" ou um "adeus".

Quando se chega num porto - sendo que neste é onde tudo começa ou tudo termina as expectativas sobre o que vai encontrar aumentam por ser sempre um lugar de descoberta. Porque nada está pronto, mas tudo está para ser construído ou compreendido no seu processo continuo de relações socioculturais ou socioeducativas. A recepção na comunidade é um momento de encontro como se o visitante fizesse parte do lugar - e, fazendo parte, passa a ter e viver a liberdade de estar junto e ser bem recebido por todos os comunitários, professores e alunos, mantendo diálogo de contato. Toda vez que retornar à comunidade para dar continuidade à pesquisa, será como se fosse à primeira vez.

Os primeiros momentos são de intensa exploração mental do lugar, onde tudo passa a ser observado na tentativa de compreensão da dinâmica natural e humana, seja na várzea ou na terra firme, como elementos estruturantes de cada comunidade, resultados de relações socioeconômicas ou socioambientais. Porque o sentido é conhecer para melhor compreender a geografia do lugar e sua representação cartográfica, em todo processo de aprendizagem pelos sujeitos envolvidos diretamente no processo educativo ou escolar - professor e o estudante.

É neste momento de ir ao encontro do objeto pensado, para torná-lo concreto, que emerge o medo, porque este é também reflexo de toda relação cultural de construção do próprio ser humano (TUAN, 2005) e passa ser importante por abrir reflexões sobre a tensão existente entre o saber formal e o saber tradicional. Então, para superação do medo e das inquietações, para melhor trabalhar a leitura do pretendido na pesquisa, foi necessário se sentir e ser parte integrante da comunidade e ao mesmo tempo estar presente e junto na sala 
de aula em processo interativo com os professores, alunos, gestoras e pais de alunos, dialogando e aprendendo através dos risos, dos abraços, de um gole de café e até mesmo nas rodas de conversas.

E, nesse ritmo de engajamento comunitário, foi possível perceber - e assim projetar - a tensão existente entre conhecimento escolar e conhecimento tradicional, dentro do estudo de caso, pois foi observada a existência de um fosso que os separam - apesar de um estar próximo do outro que, em decorrência desta situação, fez-se a seguinte projeção para ilustrar a geografia e as possibilidades de representações comunitárias.

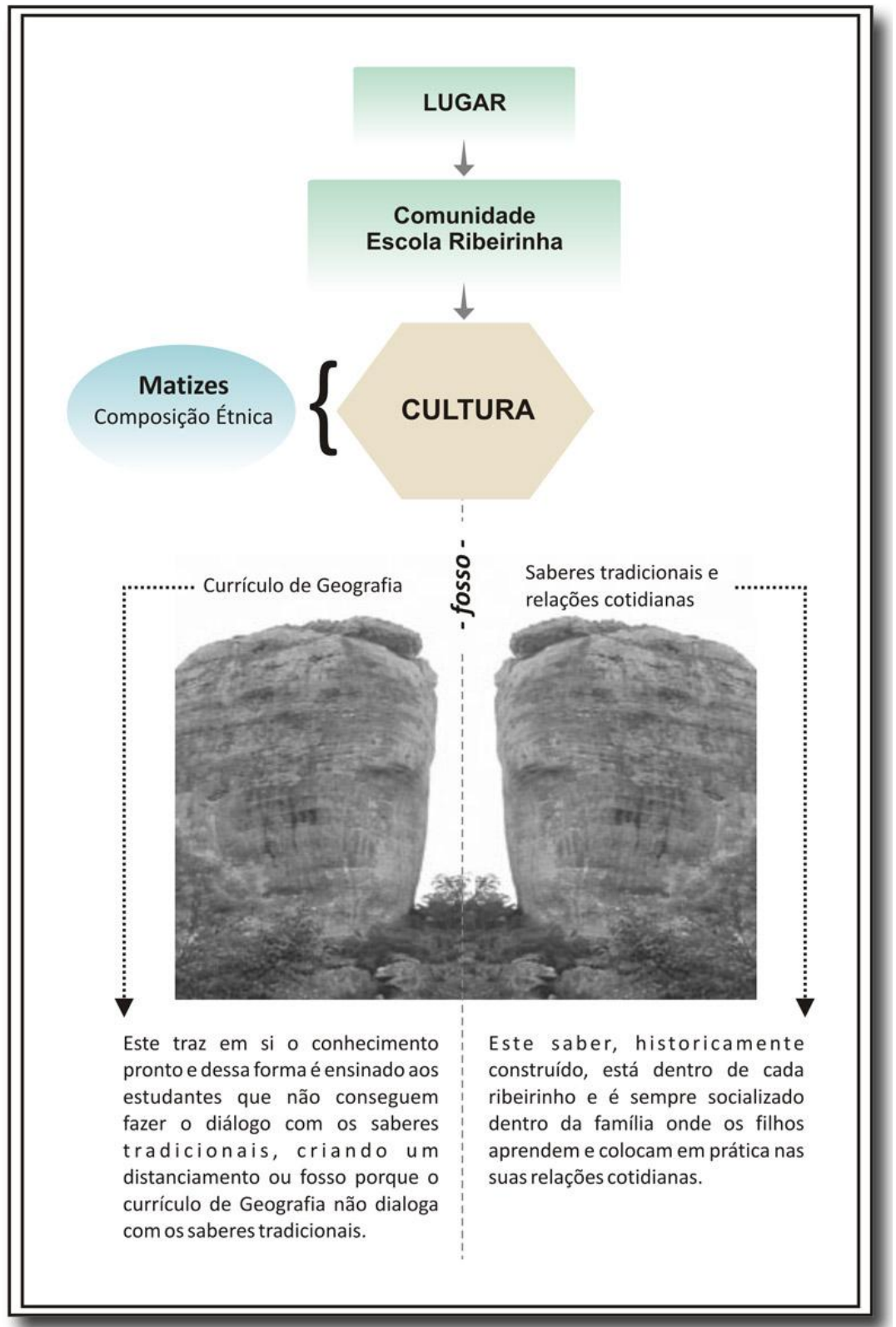

Figura 26 - Esquema representativo da tensão: escola - currículo/saber tradicional Org.: Camilo Ramos 
Este primeiro esquema (figura 26) procura mostrar a cultura como eixo central estabelecido entre o currículo de geografia e os saberes tradicionais, podendo ser o eixo de união entre os dois saberes e fazendo desaparecer o fosso existente porque já foi analisado e compreendido e, ainda, romper com a atual estrutura escolar. É importante salientar a existência da tensão entre o saber geográfico formal e o saber tradicional em todas as escolas ribeirinhas do interior da Amazônia e o que está sendo apresentado, discutido, analisado nesta tese. Pode ser o eixo norteador para a superação deste distanciamento entre os dois saberes e assim elevar o ensino como o propulsor de mudanças estruturais na e da política educacional.

Há de se considerar a importância dos matizes existentes nas comunidades ribeirinhas e para tornar o currículo mais significativo no processo ensino-aprendizagem, as categorias geográficas devem ser trabalhadas para que, de posse das mesmas, os estudantes possam ler e entender a sua realidade: lugar, espaço geográfico, paisagem e território, em todos os anos do ensino fundamental e médio (CAVALCANTI, 1998). Desta forma, o estudante vai construir sua base de conhecimento podendo se posicionar criticamente contra todo processo de exploração que o envolve e manter uma postura crítica em relação às múltiplas realidades socioeconômicas e ambientais resultante de interesses particulares internos e externos.

O segundo esquema (figura 27) procura mostrar as relações existentes na geografia das escolas das comunidades ribeirinhas, considerando os ambientes de várzea e terra firme como parte fundante de toda relação socioeducativa e de construções de múltiplos saberes e da firmação de pertencimento (ALMEIDA, 2010). Estes dois ambientes refletem nos seus moradores o lugar do viver. O primeiro, da várzea, em virtude da sazonalidade do rio apresenta sempre um início de vida em cada enchente ou em cada vazante, sendo um recomeço de tudo. $\mathrm{O}$ segundo, da terra firme, tem em sua vida uma continuidade e não vive a sazonalidade da enchente, mas é afetado pela vazante, por causa da dependência do acesso ao alimento básico, oriundos dos lagos de várzea - o peixe de cada dia. 


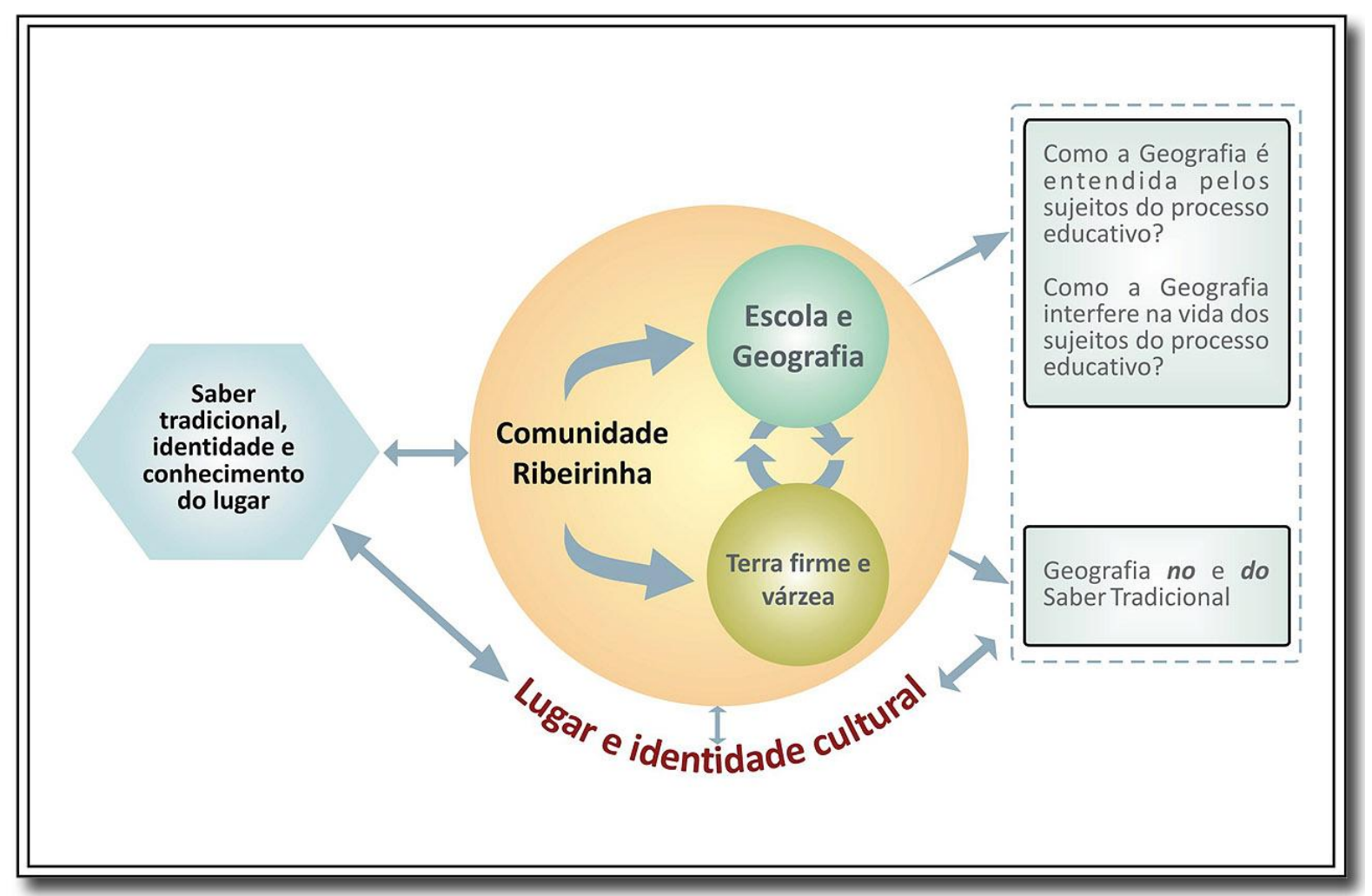

Figura 27: Relações de saberes geográficos e concepções educativas Org.: Camilo Ramos

Tanto os sujeitos da várzea como os da terra firme conhecem e tem, no seu viver, a geografia do lugar, presente no seu fazer cotidiano. Este fazer está no ato de escolher o melhor terreno e a época certa para plantar e esperar amadurecer para poder colher, isto na terra firme. Os da várzea sabem o tempo de plantar e o tempo de colher, para ter sempre o alimento básico e para comercializar. Esses moradores aprenderam a observar o comportamento dos seus ambientes de vida e por isso possuem tempos desiguais de cultivar e de criar animais, assim como são diferentes no ato de educar seus filhos para ajustarem dentro dos dois sistemas naturais.

Esse olhar em saber de quem vive sobre a água ou na parte de terras contínuas nasce da procura em aprender, observando o comportamento climático (o calor e a ocorrência de chuva), o comportamento dos animais e o uso dos ensinamentos de seus antepassados para compreender cada fenômeno natural e não ser surpreendido. Por isso, o ribeirinho procura estar sempre preparado para o ano seguinte ou para as mudanças rápidas ocorridas atualmente, para não ser apanhando de surpresa. Mesmo assim, são fortes e batalhadores, 
demonstrando o seu grau de resistência e sua insistência em permanecer cultivando o seu lugar de vida que foi também lugar de seus antepassados.

Cada ribeirinho tem em si o sentimento de vencedor e procura demonstrar na sua simplicidade de viver e na sua pacata forma de receber quem chega na sua casa.

\subsection{Geografia das quatro paredes nas escolas ribeirinhas de Parintins}

Em todo percurso da construção desta tese foram apresentadas possibilidades para uma proposta curricular que ajude a leitura do lugar de vida dos sujeitos do processo educativo, tornando o ensino de Geografia - base estruturante de compreensão das múltiplas relações socioeconômicas e socioambientais que interferem diretamente na vida de qualquer sujeito nos longínquos estirões amazônicos - como um sistema dinâmico e envolvente de cada realidade local, nacional ou global.

Nas sugestões, estão explicitas e implícitas a vontade de construção de um currículo e de uma escola diferente, com propostas de ensino-aprendizagem de Geografia que atenda os anseios dos aprendentes ribeirinhos e que estes se sintam valorizados com o que aprendem, quando ressignificam os conteúdos praticados nas suas relações cotidianas.

O olhar se verticaliza sobre a proposta curricular construída pela Secretaria Municipal de Educação de Parintins e enviada a cada escola ribeirinha, tanto de terra firme quanto de várzea, também para as escolas da cidade, para que os conteúdos sejam trabalhados no período de um ano letivo, ou seja, 200 dias letivos com uma carga anual de 800 horas/aula (LDB 9394/1996).

Esta proposta curricular possui os objetivos, as competências e as habilidades, seguindo as recomendações dos Paramentos Curriculares Nacionais (1998), mas os conteúdos seguem a forma preteritamente trabalhada nas escolas. A Tabela 3 traz a apresentação dos conteúdos do $6^{\circ}$ ano, deixa visível a distribuição dos conteúdos, os quais diferem do que apresenta os PCN. Foram retiradas as competências e habilidades para analisar os conteúdos. 


\section{Proposta de Conteúdo no Município de Parintins $-6^{\circ}$ ano}

2. O tempo da natureza:

- Origem do universo, movimentos e transformações;

1. Geografia: conceito e importância do estudo

- Corpos e seus movimentos;

- Movimentos da Terra e as estações do ano;

- Camadas que envolvem a Terra.

3. Coordenadas Geográficas:

- Paralelos e Meridianos;

- Latitude e Longitude;

- As zonas da Terra;

- Fusos horários.

5. A natureza e o trabalho humano: . A natureza A natureza e seus elementos: o ar, a água, os animais, os vegetais e os minerais;

- Interdependência dos elementos da natureza (ecossistema);

- O trabalho humano

- A construção do espaço geográfico através do trabalho;

- A natureza transformada em produto pelo trabalho humano.

4. Espaço Natural Geográfico:

- Descrição do espaço vivido;

- Mapas;

- Legendas;

- Escalas;

- Orientação.

6. Aproveitamento econômico do espaço e suas relações com as condições naturais:

Setores econômicos:

- Primário: pecuária; extrativismo (animal, vegetal e mineral); agricultura; pesca.

- Influência do clima sobre as atividades econômicas primárias (agricultura, pecuária, silvicultura, caça, pesca, extrativismo).

- Secundário: indústria, madeireira, alimentícia, naval, movelaria, olaria, serralheria, confecções, entre outros;

- Terciários: comércio, turismo e serviços.

Atividade Extrativa vegetal

- O extrativismo como atividade não reprodutiva;

- O extrativismo e a destruição do meio ambiente;

- As formas de extrativismo vegetal;

- Agricultura e as condições naturais (solo, clima e relevo);

- Impactos ambientais causados pela agricultura;

- Atividade extrativa mineral

- Minerais e minérios;

- Forma de extrativismo mineral;

- Extrativismo mineral e meio ambiente.

Tabela 3: Conteúdos do $6^{\circ}$ ano.

Fonte: Secretaria Municipal de Educação de Parintins/ 2011-2012 
Estes conteúdos merecem uma atenção especial e alguns aspectos devem ser questionados: a distribuição dos conteúdos é estanque e fragmentada não havendo comunicação entre eles e não dando dimensão de seu grau de importância para a vida cotidiana do estudante ribeirinho, que pratica os conteúdos "Natureza e o trabalho humano" e "Aproveitamento econômico do espaço e suas relações com as condições naturais", mas quando ensinado na sala de aula são vistos distantes de suas atividades diárias.

Esses alunos convivem com a pecuária cujas criações são a bovina e bufalina. Praticam agricultura nas várzeas e na terra firme. Aprendem com seus pais a extrair recursos de origem vegetal, como: andiroba, copaíba, breu branco, palha, cipó, tábua e frutas diversificadas. Praticam a pesca utilizando todos os tipos de arreios e comercializam o peixe. Estes pontos apresentados são para demonstrar o que existe próximo do estudante ribeirinho, mas o conteúdo geográfico trabalhado na sala de aula o deixa distante de sua realidade.

Os conteúdos de "coordenadas geográficas e mapas, legendas, escalas e orientações" poderiam ser trabalhados conjuntamente e não de forma separada. Pelo que foi observado, estes conteúdos são ministrados superficialmente porque o professor não domina os conceitos cartográficos ou por tentar trabalhar da mesma forma que aprendeu na universidade. Existem várias orientações de como trabalhar a cartografia e uma das sugestões é a atividade com Mapas Mentais (NOGUEIRA, 2006), porque as representações partem do vivido e do experienciado. No percurso do ensino, devem ser inseridos os conceitos de escala, legenda, paralelos, meridianos, coordenadas geográficas. Isto daria consistência ao ensinado e romperia com o ensino fragmentado.

Quanto aos conteúdos voltados à astronomia, há somente o que o livro didático apresenta nos desenhos. Não é ensinado ao aluno observar as estrelas e procurar questionar o porquê da existência das estrelas, dos planetas e como se formam as constelações para tentar compreender se exercem influência ou não sobre a Terra. Entender os meteoritos atravessando a camada atmosférica que são chamados de "estrelas-cadente". Tudo pode ser observado para ser compreendido mas, da forma como está sendo ensinado, tudo fica distante da realidade vivida e praticada nas escolas e comunidades ribeirinhas amazônicas.

Esta forma de ensinar fragmentada encontra-se no $7^{\circ}$ ano, conforme distribuição dos conteúdos na Tabela 4. No primeiro momento não há comunicação com os conteúdos estudados no $6^{\circ}$ Ano, ficando evidente o problema da continuidade do que foi estudado e também da não associação do saber tradicional nesta construção de ensino de geografia. 


\section{Proposta de Conteúdo do Currículo no Município de Parintins $-\mathbf{7}^{\circ}$ ano}

1. O Brasil no globo terrestre: A produção do espaço geográfico brasileiro; Localização e área;

- $\quad$ Antes de 1500 os povos que viviam onde hoje é o Brasil. (Quem e quantos eram, sua distribuição espacial, quem eram para os europeus);

- $\quad$ Colonizador e a apropriação dos espaços indígenas (do contato à colonização e relações de conflito).

- Órgãos defensores e os espaços indígenas do século $\mathrm{XX}$ ao XXI, sua regulamentação e seu futuro

Regiões brasileiras:

4. Região Norte: A construção de espaços geográficos:

Estados e capitais

- Relevo

- Hidrografia

- Clima

- Vegetação

- $\quad$ Formação da população tipos e características

- O Extrativismo do látex

- As reservas extrativistas e os espaços geográficos atuais.
2. População brasileira:

5. Região Nordeste: A

- O espaço Geográfico do

7. Região Sudeste: a construção de espaços geográficos

Estados e capitais

Relevo

Hidrografia

Clima

Vegetação

Formação da população tipos e características

A mineração e a produção de espaços geográficos

A imigração estrangeira

O sudeste e suas empresas multinacionais.

Tabela 4: Conteúdos do $7^{\circ}$ ano.

Fonte: Secretaria Municipal de Educação de Parintins/ 2011-2012

A desertificação dos campos
Densidade demográfica;

Crescimento da população;

Mobilidade da população;

Formação do povo brasileiro. construção de espaços geográficos

Estados e capitais

Relevo

Hidrografia

Clima

Vegetação

Formação da população tipos e características

O Espaço geográfico da

Zona da Mata atual

O Espaço geográfico do Agreste

O Espaço geográfico do Sertão Meio Norte.

3. Regionalização do espaço brasileiro:

As várias divisões que o Brasil já teve desde a sua descoberta;

Divisão Regional do Brasil: Estados e Capitais (segundo IBGE).

- Divisão Geoeconômica do Brasil.

6. Região Centro-Oeste: A construção de espaços geográficos.

- Estados e capitais

Relevo

Hidrografia

- Clima

\section{Vegetação}

Formação da população tipos e características

- $\quad$ A produção de espaços em tempos recentes (1940 a 2000).

9. O território brasileiro e as condições ambientais

8. Região Sul: a construção de espaços geográficos

Estados e capitais

Relevo

Hidrografia

Clima

\section{Vegetação}

Formação da população tipos e características

A destruição da mata dos pinhais. do Rio Grande do Sul.
- Biodiversidade e ambientalismo (as unidades de conservação da natureza do Brasil)

- O novo Código Florestal brasileiro 
Esta proposta de conteúdo do $7^{\circ}$ ano está voltada inteiramente para o Brasil e poderia representar caminhos de conhecimento sobre cada região ou cada lugar na sua dimensão sistêmica, mas apresenta vários Brasis e múltiplas características humanas e naturais de forma isolada e não deixando clara a comunicação e interferência social, natural ou econômica em todo território nacional. Não dimensiona a relação centro-periferia e o processo da expansão urbano-social, as perdas de ordem sistêmica ambiental, responsável pela alteração de aspectos hidrográficos e geomorfológicos, resultando em catástrofe nas cidades e também nas áreas de produção agropecuária. Além desses impactos, há também alteração na dinâmica dos rios, lagos, paranás, igarapés e nascentes, tornando a vida no Brasil problemática, onde há destaque para poluição e contaminação de canais e proliferação de doenças como dengue, malária e outras provenientes da destruição ou alteração dos habitats naturais.

A proposta de conteúdo com estrutura fragmentada conduz à uma leitura parcial e superficial do Brasil e não permite a compreensão de conjunto e das relações intra e interregional, nos que diz respeito aos aspectos socioculturais, socioeconômicos, socioambientais. Dessa forma, o estudante ribeirinho nunca terá uma leitura de conjunto do Brasil e nem entenderá os reflexos positivos ou negativos diretamente na vida comunitária dentro da Amazônia e, assim, nunca valorizará a Geografia.

No $8^{\circ}$ ano, o encaminhamento de conteúdo corresponde ao estudo da construção do continente americano, tanto do aspecto físico-geográfico quanto do aspecto socioespacial e sociocultural. Convida a uma viagem a partir da deriva dos continentes, abrindo perspectiva de conjunto, mas o roteiro é fragmentado. Assim, como foram apresentados os conteúdos do $6^{\circ}, 7^{\circ}$ e agora no $8^{\circ}$ ano (Tabela 5), também será do $9^{\circ}$ ano onde o ensino de geografia é descritivo e quantitativo, conduzindo o estudante a decorar o ensinado e não fazendo relação das influências externas nas suas práticas cotidianas amazônicas, deixando-o sem visão de análise crítica sobre a realidade local e global que o envolve.

A Geografia ensinada não possibilita a compreensão, pelo estudante, da continuidade de rochas ou relevo e também das interferências climáticas pela circulação atmosférica da Amazônia em relação ao Nordeste e ao Sul do Brasil. Da mesma maneira que não permite o entendimento das massas de ar que atingem a Amazônia, oriundas do Atlântico, fazendo a ocorrência de mudanças no tempo através das precipitações pluviais. 
Proposta de Conteúdo do Currículo no Município de Parintins - $8^{\circ}$ ano

1. Divisão regional da Terra

Divisão da Terra em continentes

- A deriva dos continentes e as placas tectônicas Oceanos e mares (origem)

As grandes paisagens naturais

A divisão norte/sul - desenvolvimento

As origens da dependência

Divisão internacional do Trabalho

A globalização

\section{América Latina}

Localização geográfica

- Regiões da América Latina (divisão política)

- México

- América Central

- América Andina

- Guiana

- Platina

- Brasil

- Relevo

- Clima

- Vegetação

- Hidrografia

5. América Anglo Saxônica e o Canadá Localização geográfica

Regiões da América Anglo-Saxônica

Relevo

Clima

- Vegetação e hidrografia

- Canadá

- $\quad$ Aspectos econômicos e sociais

- NAFTA

7. Oceania - Novíssimo Mundo

Principais características

- Divisão política da Oceania
2. Continente Americano - O Novo Mundo

Localização geográfica

Divisão do continente

- América do Norte

- América Central

- América do Sul

- Divisão histórico-cultural

- América Latina (o que significa)

- América Anglo-Saxônica (o que significa)

4. Aspectos econômicos da América Latina Extrativismo: agricultura e pecuária

Atividade Industrial

- Comércio e transporte

- MERCOSUL

Tabela 5: Conteúdos do $8^{\circ}$ ano.

Fonte: Secretária Municipal de Educação de Parintins/ 2011-2012

6. As regiões polares

O Ártico

- Aspectos físicos

- População e atividades econômicas

- Antártida

- Aspectos físicos

- Potencial econômico e científico 
Estes conteúdos ensinados e aprendidos sistemicamente proporcionariam diálogos interpretativos da ocorrência dos fenômenos naturais, como geadas, alta temperaturas (secas), furacões, terremotos, maremotos, que abalam as estruturas sociais, econômicas e ambientais das sociedades e dos países americanos, refletindo sobre o Brasil e a economia global.

Conduziria o estudante à compreensão dos movimentos migratórios não só dos animais como também das pessoas, em tempos diferentes, à procura de novos espaços econômicos de trabalho e de estudo, principalmente para os Estados Unidos da América. Na discussão sobre migração, o estudante poderia ser conduzido a compreender a migração da várzea para a terra firme tanto por conta da enchente quanto pela plantação das roças de mandioca e produção de farinha, em diferentes escalas.

Estas observações levam a postular a necessidade da articulação do local com global, através de consultas em revistas, livros, documentários, obras literárias, onde o estudante estaria fazendo um exercício de estudo e pesquisa para construção de conhecimentos. Como não há luz elétrica na várzea, as notícias podem ser acompanhadas pelo rádio, através da $V o z$ do Brasil e na comunidade de terra firme, onde há luz elétrica. Os estudantes podem fazer acompanhamento dos acontecimentos nacionais e internacionais através dos telejornais.

Os conteúdos apresentados sobre o continente americano e ensinados de forma articulada aproximariam as realidades sociais e ambientais, as desigualdades socioeconômicas, das realidades vividas pelos estudantes ribeirinhos em cada comunidade. É importante salientar a necessidade de utilizar sempre a base cartográfica para representar as compreensões e também se o uso dos conceitos das categorias geográficas para solidificar sua base teórica de leitura analítica.

Os conteúdos do $9^{\circ}$ ano (Tabela 6) seguem o mesmo padrão descritivo e quantitativo sem conduzir o estudante à compreensão da organização sócio-espacial da Europa, da África, da Ásia e suas múltiplas relações socioeconômicas e um quadro de instabilidade geopolítica, decorrente das políticas geoeconômicas de exploração de recursos naturais e do processo expansionista dos novos países hegemônicos, a insegurança dos países imperialistas frente aos avanços técnico-científicos dos emergentes.

O ensino sendo fragmentado não deixa avançar a reflexão unificada e totalizante sobre a complexidade do mundo contemporânea e seus reflexos locais. Impossibilita ainda o aprofundamento do conhecimento pelos alunos impedindo-os de exercitarem criativamente a consolidação dos conteúdos estudados do $6^{\circ}$ ao $9^{\circ}$ ano. 
Proposta de Conteúdo do Currículo no Município de Parintins- 9 Ano

1. Continente europeu

- Localização geográfica

- Divisão política

- Limites e área

- População atual

- Aspectos físicos

- Relevo

- Clima

- Vegetação

- Hidrografia

- União Europeia

\section{Continente africano}

- Localização geográfica

- Divisão política

- Limites e área

- População atual

Aspectos físicos

- Relevo

- Clima

- Vegetação

- Hidrografia

Regiões da África

- África do Norte

- África Ocidental

- África Centro-Ocidental

- África Meridional

- África Centro-Oriental

- Problemas Sociais

- Fome

- Doenças

\section{Continente asiático}
4. Os tigres asiáticos.

- Localização geográfica

- Divisão política

- Limites e área

- População atual

- Regiões da Ásia

- Oriente Médio

- Subcontinente indiano

- Sudeste e Leste asiático

- Extremo Oriente.

Tabela 6: Conteúdos do $9^{\circ}$ ano

Fonte: Secretária Municipal de Educação de Parintins/ 2011-2012 
Trabalhar os conteúdos nesta estrutura curricular de Geografia é um desafio enfrentado pelos professores ribeirinhos do município de Parintins, principalmente das escolas Tiradentes e Tukasa Uetsuka, pois não conseguem romper as imposições ou as amarras estabelecidas ao processo ensino-aprendizagem porque tem que cumprir a lista de conteúdos do currículo, reduzindo a capacidade criativa do professor e do próprio estudante. Fernandes (2002, p.243) faz apresenta a seguinte argumentação:

\begin{abstract}
Nessa escola, reuniram-se certos saberes em vez de outros, algumas geografias no lugar de outras; os compêndios em uma língua transformada em nacional ou na língua do colonizador; alguns professores em vez de outros. Podemos dizer, estendendo um pouco a idéia de tradição seletiva concernente à historia do currículo, que houve tradição seletiva em todos os aspectos relacionados à própria conformação da disciplina Geografia, como, por exemplo, a formação de professores.
\end{abstract}

Esta argumentação de Fernandes remete diretamente ao processo de formação de professores de Geografia mas o que se pretendeu foi ressaltar as heranças colonialistas da escola e da estrutura curricular que teima em permanecer amordaçando a liberdade do estudante aprender e exercitar sua cidadania através do que aprendeu. Enquanto não existir essa liberdade, o estudante não se tornará um leitor crítico da realidade social local, nacional e global.

Outro conflito interno que o professor enfrenta é o que aprendeu na Licenciatura de Geografia e a Geografia que é ensinada na escola. A situação se agrava quando este professor não possui formação em Geografia, passando a reproduzir somente o que se encontra nos livros didáticos. Quando possui formação em Geografia, quer ensinar tudo que aprendeu e como aprendeu, por não conseguir realizar a transposição do conhecimento acadêmico para um conhecimento escolar, segundo Cavalcanti (2012) a geografia aprendida na universidade deve ser o suporte estruturante para a Geografia que se ensina na escola. Por ser processo e também por expressar a adequação de conteúdos em relação à realidade, procurando entender que tanta uma Geografia quanto a outra são diferentes e que se relacionam na estruturação da vida e das relações cotidianas da vida do estudante.

As reflexões sobre o que se ensina em Geografia na escola ribeirinha em confronto ao que aprendeu o professor na universidade para ensinar, passam a ser, na prática escolar, descrições de aspectos físicos e humanos, enumerações de acontecimentos e registros de fenômenos naturais e sociais, decorrente de uma proposta curricular cristalizada como verdade absoluta e não podendo ser alterada, negando a estruturação de conceitos geográficos 
para associar o saber tradicional em toda extensão necessária do espaço de vida cotidiana, sem perder a dinâmica e complexa transformação do mundo contemporânea, agindo indiretamente no lugar. Assim sendo, segundo ainda Cavalcanti (2008, p.50) “O lugar é, portanto, o habitual da vida cotidiana, mas, por outro lado, também é por onde se concretizam relações e processos globais. O lugar produz-se na relação do mundial com o local, que é ao mesmo tempo a possibilidade de manifestações do global e de realizações de resistência à globalização". Da forma como esta estruturada ${ }^{17}$ a Geografia das quatro paredes das escolas ribeirinhas, ou seja, a apresentação dos conteúdos através da proposta curricular encadeadora de um ensino de base tradicional, não se chegará ao nível de discussão e compreensão do valor da Geografia Escolar, possibilitadora de mudanças estruturais socioeducativa e sociopolítica.

O Ensino de Geografia nas escolas ribeirinhas de Parintins ou da Amazônia, precisa romper as estruturas para obter liberdade exploratória do laboratório geográfico amazônico, conduzindo os estudantes a entenderem o solo e sua importância para as plantações. Compreenderem a dinâmica dos rios, igarapés, lagos, conservando as nascentes para a vida na floresta e para o próprio ser humano. Conceberem o funcionamento sistêmico da Amazônia no e do lugar, projetando o raio de influência e abrangência no contexto nacional e global. Considerando também toda riqueza aquífera, mineralógica, madeireira, florística e faunística, onde acontece o funcionamento da teia de maneira integral, mas muito fragilizada diante da exploração antrópica de modo irracional. Toda mudança para a escola ribeirinha poderia ser baseada na proposta da escola indígena ou em toda proposta de construção coletiva.

Para obter esse tipo de leitura compreensiva é preciso trabalhar com os conceitos geográficos, oportunizando ao estudante o exercício mental de refletir sobre o que vê no seu entorno, a partir de conhecimento adquirido na sala de aula e alimentado por todo saber advindo dos ensinamentos de seus pais nos diversos percursos diários. Assim se estaria construindo uma escola e uma proposta curricular desejável, a partir das discussões coletivas comunitárias.

A escola e sua estrutura curricular - seja ela ribeirinha ou urbana, de Parintins ou de qualquer lugar do Brasil - vivem momentos difíceis e enfrentam crises profundas por não dar respostas desejadas à contribuição na formação do estudante e também por não conseguir acompanhar as mudanças e as complexidades do mundo contemporâneo, onde surgem novas demandas a serem trabalhadas na geografia porque surgem novas territorialidades com as

\footnotetext{
${ }^{17}$ Esta estruturação vale para a maioria das escolas brasileiras.
} 
lutas das minorias étnicas, por seus direitos e a questão de gênero. Há exigência de uma geografia que possa despertar interesse dos estudantes em aprendê-la para compreender a sua diversidade local reflexo das desigualdades da sociedade, onde se destacam as diversas contradições no seu próprio interior, mas precisando de respostas aprofundadas e críticas.

\subsection{Geografia na comunidade ribeirinha de Parintins: entre o risco e o rabisco do estudante}

Ao entrar no universo do estudante, percebe-se como constrói as suas representações de significados e seu nível de abstração, a partir da compreensão da geografia existente na comunidade ribeirinha, demonstrando a visão que possui de seu mundo como sujeito construtor de sua própria história dentro de lugar de vida.

Este universo, mundo ou o lugar mencionado, são as comunidades ribeirinhas detentoras de múltiplos significados e representações de vida, clarificando o contexto amazônico vivido e percebido nas lidas diárias de cada estudante, demonstradas por representações gráficas (desenhos). Os desenhos evidenciam todo processo de aprendizagem na terra firme ou na várzea.

Para compreender as representações dos estudantes foi necessário se apoderar de saberes de Almeida, Rosângela (2003) quando apresenta desenhos de estudante em sua obra Do desenho ao mapa: iniciação cartográfica na escola, na qual procura dimensionar a representação espacial concebida e projetada a partir de um estudo do meio, realizado com alunos que, motivados, fizeram representações gráficas e cartográficas sobre o bairro visitado. Além desse livro, lançou-se mão de mais duas obras organizadas por Almeida: Cartografia Escolar (2007) e Novos rumos da cartografia escolar: currículo, linguagem e tecnologia (2011), dando suporte na leitura analítica sobre os desenhos dos estudantes ribeirinhos. Outra obra enriquecedora da análise foi Geografia e Conhecimento Cartográfico: a cartografia no movimento de renovação da Geografia brasileira e a importância do seu uso de mapas, de Souza, José Gilberto e Katuta (2001), resultado de dissertação de mestrado e apresenta preocupações quanto à metodologia, o estudo cartográfico, abrindo discussões diversas e sobre a dicotomia da geografia e formação de professor. Outra obra importante, organizada por Jörn Seemann (2005), é A aventura cartográfica: perspectivas, pesquisas e reflexões sobre a cartografia humana, por auxiliar e embasar a compreensão da dimensão cartográfica e sua importância para o ensino. 
Após a realização da viagem por este universo de conhecimento cientifico no sentido de obter uma base teórica de leitura e reflexão sobre os desenhos dos estudantes ribeirinhos, houve aproximação direta em seu universo representado. Estes desenhos foram projetados a partir de questões instigadoras sobre sua realidade local. Então, foi feita a apresentação unificada por turma, pois há muita semelhança nas respostas, mas os desenhos estão cheios de significados e significante. Diálogos abertos foram necessários para explicar o andamento da atividade, que se valeram de sua liberdade para exercitar a mente na construção e representação dos lugares por eles visitados e conhecidos, próximo ou distante de cada comunidade.

As respostas e os desenhos não serão identificados por nome dos alunos, por escola ou pela comunidade, para conservar e resguardar o direito ao anonimato. Alunos serão identificados por letras se houver necessidade e as comunidades por: da água e da terra e floresta. Outro aspecto importante é que as questões não estão ligadas ao currículo trabalhado na escola, estão voltadas mais para a verificação da compreensão geográfica da comunidade ribeirinha e das relações de trabalho de seus pais.

A resposta dos estudantes à pergunta sobre comunidade, remete a pensar suas representações e manifestações no lugar em que constrói seus momentos de aprendizagem e ressignifica seu modo de vida. 
"Comunidade é onde as pessoas ficam unidas e ajudam uma com as outras e tem o mesmo costume e é onde tem paz e harmonia. Amor e solidariedade. Comunidade é só uma família e uma família é feito de Pai e Mãe e filhos assim como minha família". (alunos do $6^{\circ}$ Ano da escola da água).

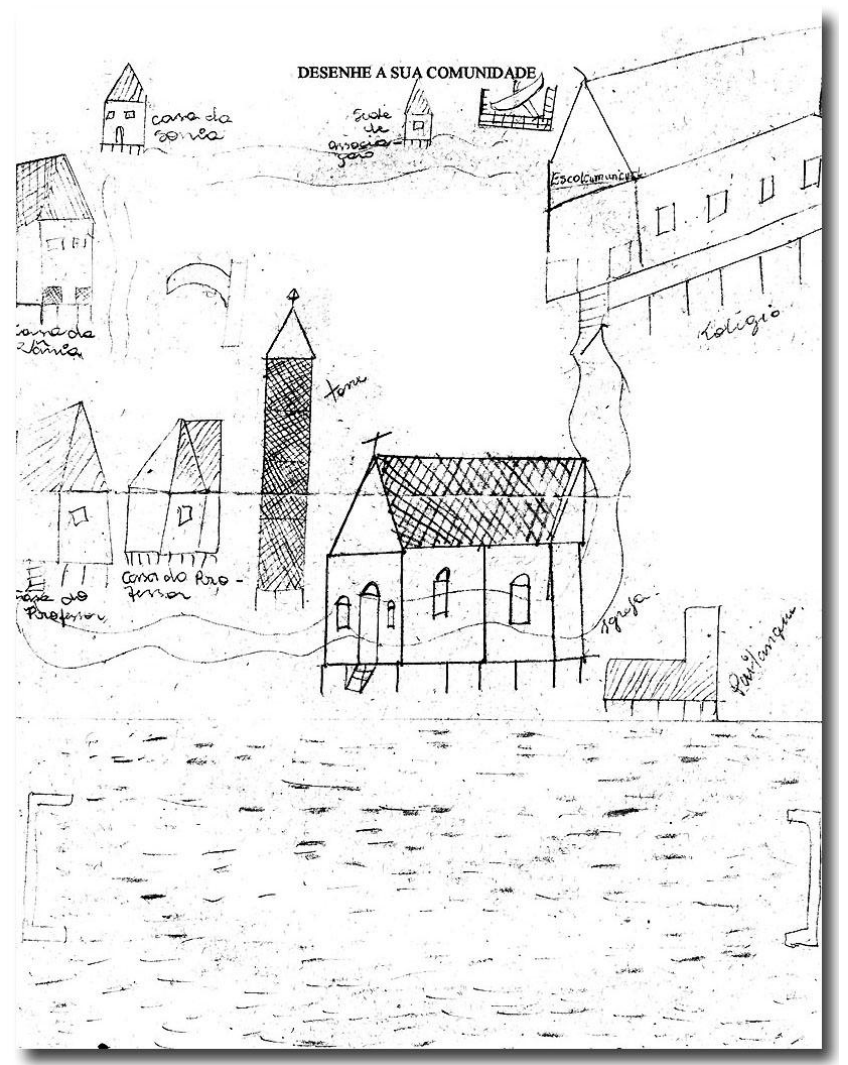

Figura 28 - aluno da água 
"A comunidade é formada por várias famílias. Em cada comunidade existem suas autoridades como. Presidente, vice-presidente, tesoureiro, agente de saúde, agente de polícia. Para a comunidade seguir em frente é precisa que todas as pessoas tomem as mesmas decisões. Através dessas funções é que se forma uma comunidade." (alunos do $7^{\circ}$ Ano da escola da água).

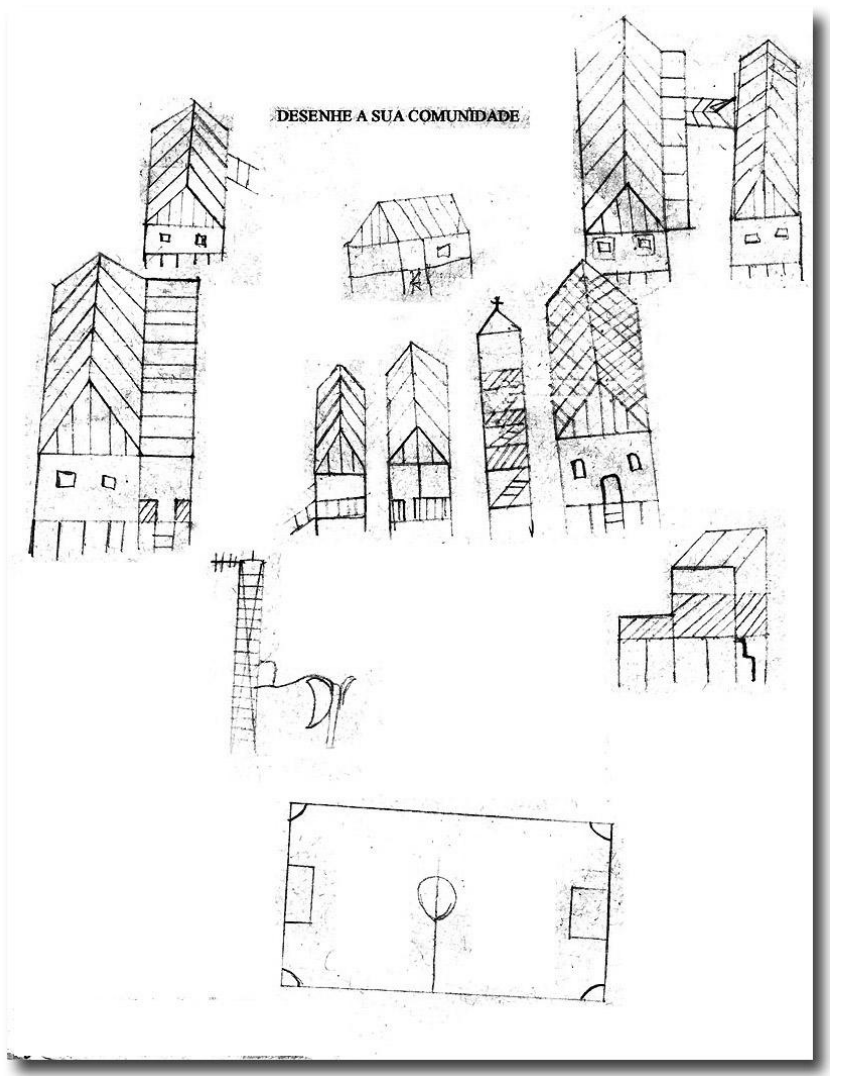

Figura 29 - aluno da água 
"A comunidade é um grupo de pessoas e ela se reúne em família. A comunidade ela é também um pouco organizada onde as pessoas podem se agrupar e fazer uma comunidade organizada e não desorganizada por que isso não dá apoio". (alunos do $8^{\circ}$ Ano da escola da água).

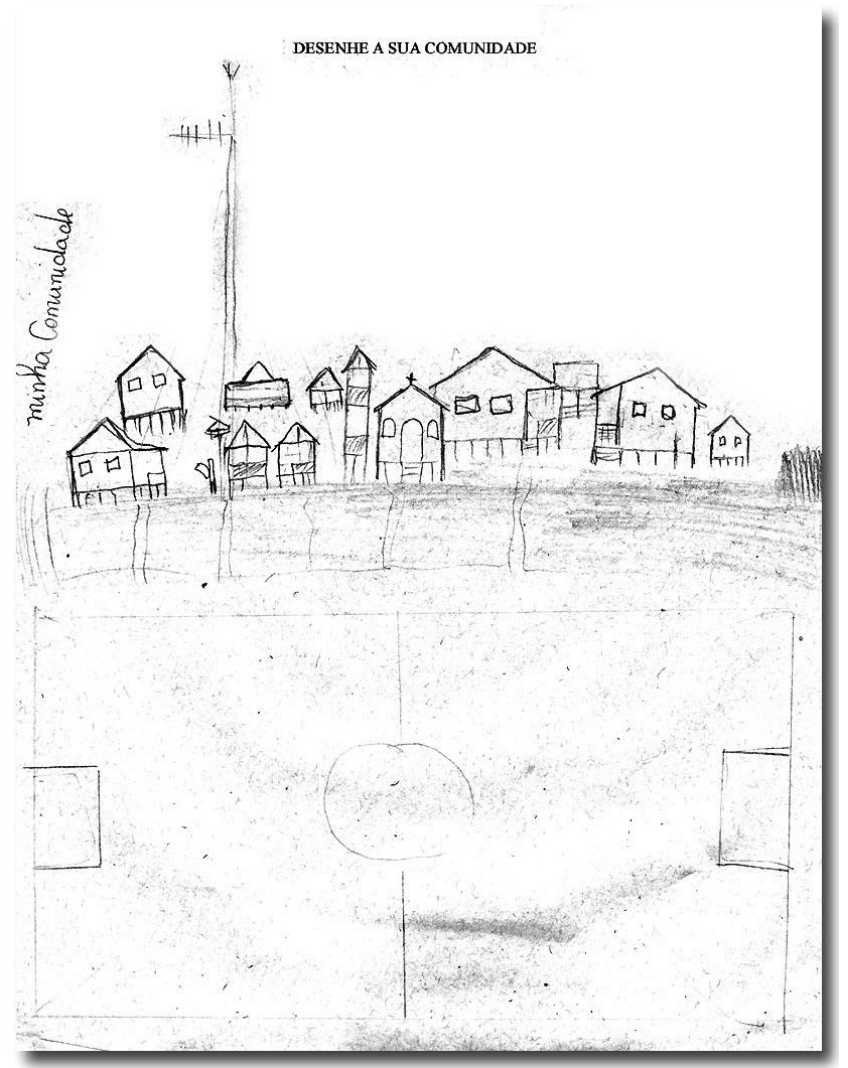

Figura 30 - aluno da água 
"A comunidade é um grupo de pessoas que se organiza para garantir o melhor caminho para crianças acordos e regras que gera a lei, dando direitos e deveres aos comunitários". (alunos do $9^{\circ}$ Ano da escola da água).

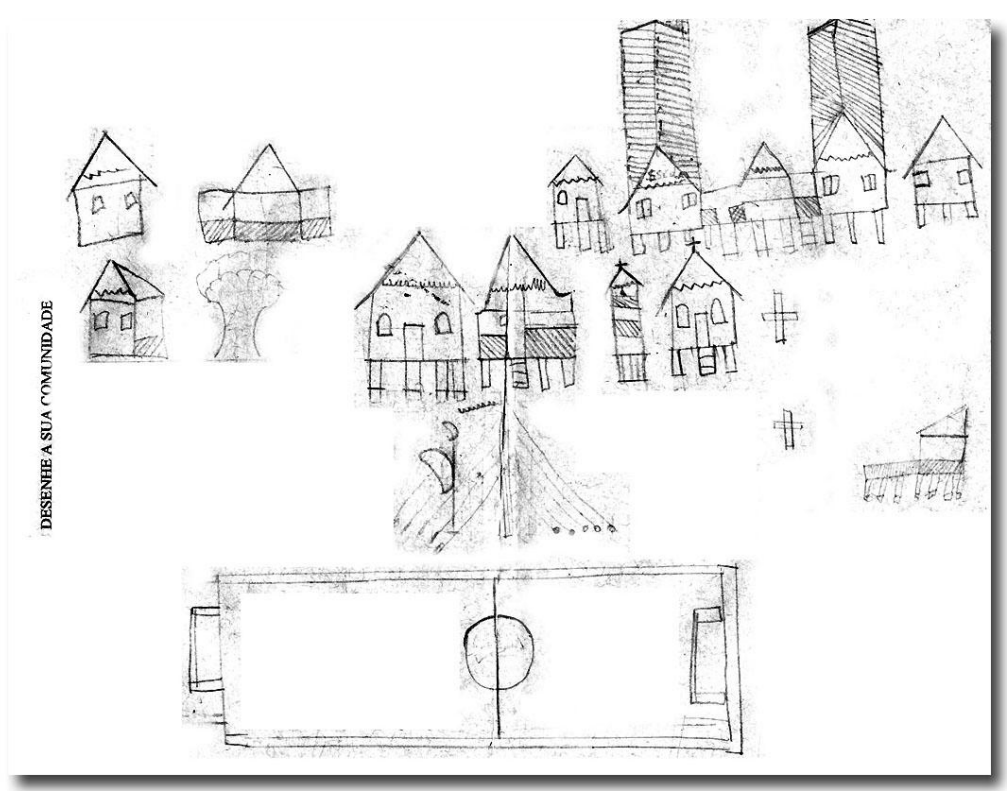

Figura 31 - aluno da água

Fica patente a unidade familiar e o processo de organização sócio espacial e tendo o reflexo de sua aprendizagem tanto na escola quanto na relação religiosa e familiar. Estes estudantes participam das reuniões com seus pais para fazerem todas as anotações do que é falado e com isso passam a aprender com as informações dialogadas pelos órgãos públicos, igrejas e escola. Sempre há inteiração e ampliação do aprendido na sala de aula.

Os alunos da escola da água retrataram a comunidade como espaço de vida e manifestaram, em cada traçado, o sentimento de pertencimento igualmente como fizeram os alunos da escola da terra e da floresta. As figuras $28,29,30$ e 31 são alunos do $6^{\circ}$ ao $9^{\circ}$ ano, onde mostraram o espaço socialmente construído, no sentido de retratar a geografia da comunidade repleta de significados e significantes.

Os alunos da escola da terra e floresta detém outra visão de comunidade, talvez seja pela proximidade da própria cidade de Parintins, tendo a influência direta do urbano nesta comunidade. 
"A comunidade é onde tem adolescentes, jovens, crianças que faz uma só família e uma grande cidade, um país que vive casas, árvores e muitos animais selvagens que se chama ser vivo são porcos, bois, cavalos, cachorro, galinha, gato. (alunos do $6^{\circ}$ ano da escola da terra e floresta)

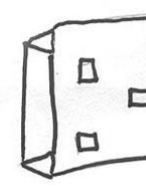
DESENHE A SUA COMUNIDADE
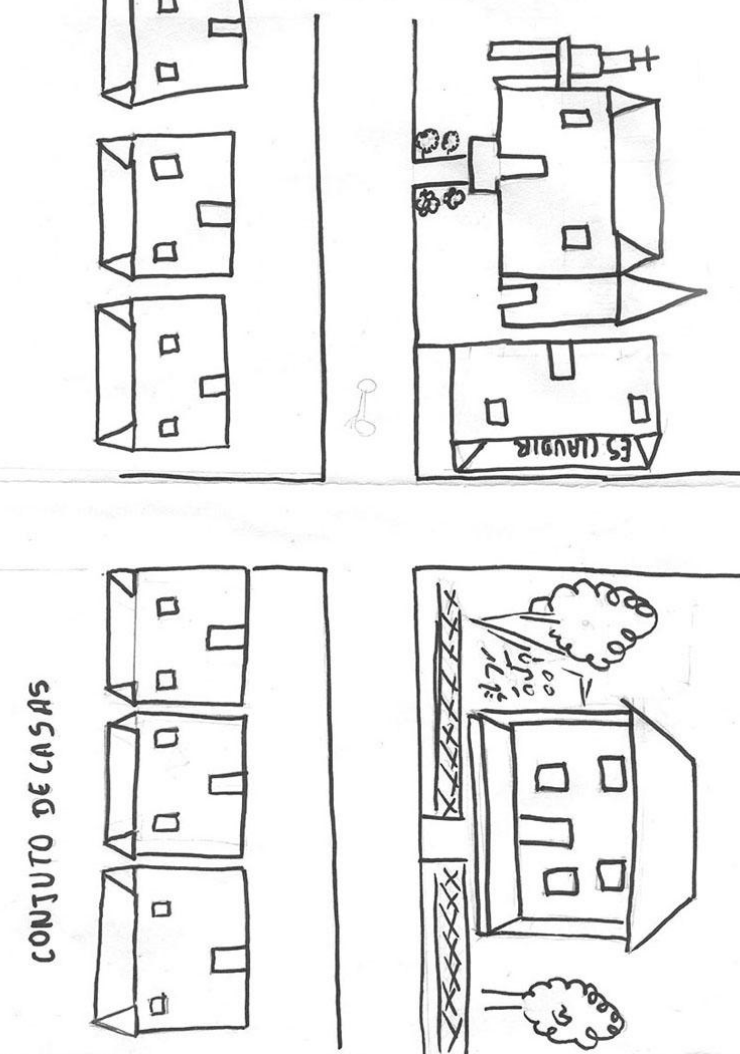

Figura 32 - aluno da terra e da floresta 
"É uma cidadezinha aonde pessoas de cidade grande vem morar e constrói sua casa. Comunidade é pequena mais muitas pessoas vão visitar. (alunos do $7^{\circ}$ Ano da escola da terra e floresta)

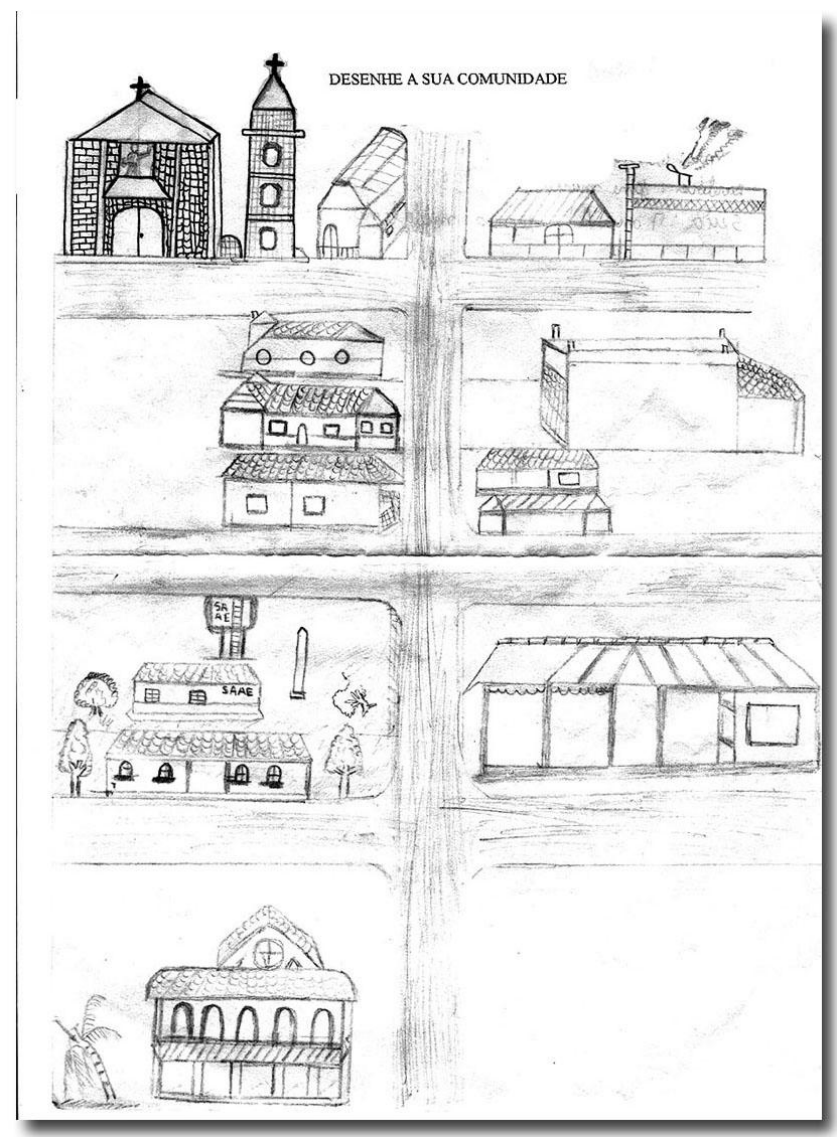

Figura 33 - aluno da terra e floresta 
"Comunidade é um município aonde há um grande movimento; bem como a cidade, por exemplo: tem movimento, tem renda de vida, onde até hoje tem bem movimento e renda de família e também temos várias rendas". (alunos do $8^{\circ}$ Ano da escola da terra e floresta)

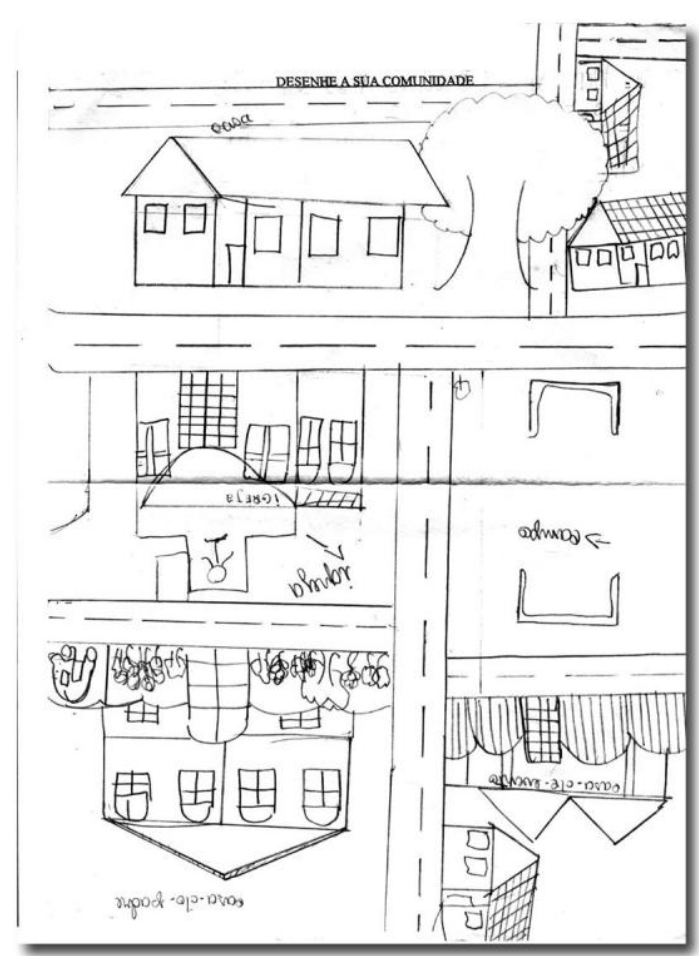

Figura 34 - aluno da terra e floresta

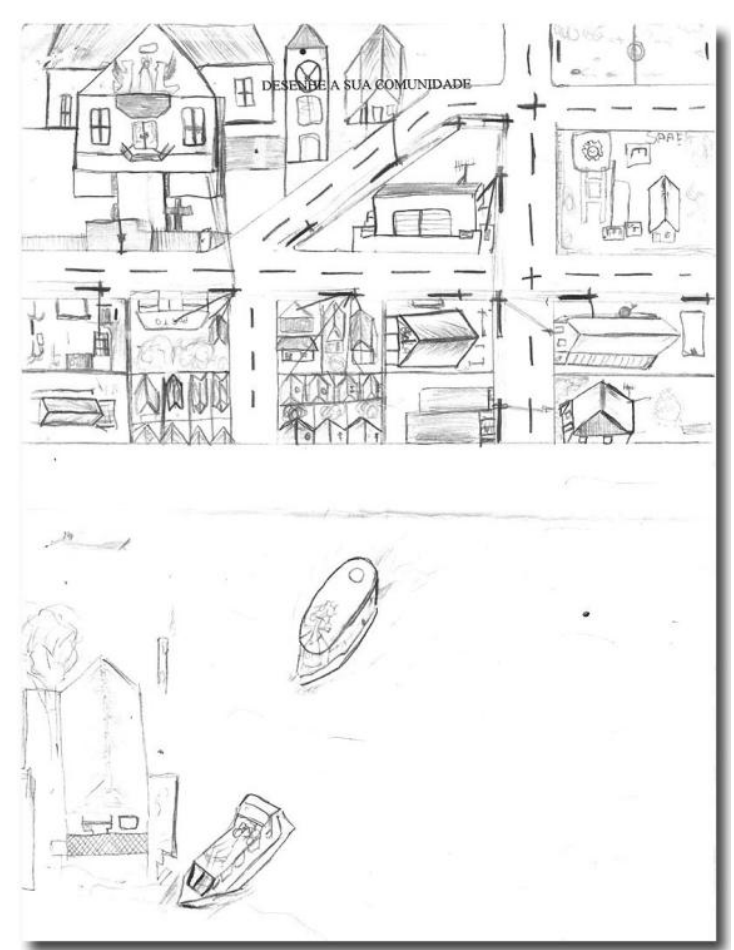

Figura 35 - aluno da terra e floresta

Pelo que foi observado, não só nas respostas mas na convivência, os estudantes relacionam comunidade ao fluxo diário de pessoas oriundas de Parintins, pela proximidade que a comunidade possui com a cidade.

Nestas respostas, os estudantes fizeram sua representação em forma de desenho, demonstrando o grau de conhecimento que possuem de sua comunidade e deixando bem claro a geografia vivida e guardada na mente para poder ser representada no papel.

Os desenhos dos estudantes da terra e florestas evidenciam a capacidade de ter na mente a sua comunidade e de representar a organização espacial. As figuras 32, 33, 34 e 35 são os espaços de vida que a cada dia. São ressignificados e traduzidos em conhecimentos geográficos e representações cartográficas.

A geografia ensinada poderia se tornar mais interessante, mais atrativa e valorizada por cada sujeito aprendente se fosse permitido associar o conteúdo estudado com a geografia vivida cotidianamente. Cada desenho representa o seu eu dentro do lugar de vida dos estudantes ribeirinhos por dar sentido ao processo de aprendizagem e concepção de espaço. 
Importante ressaltar que o exercício praticado demonstrou o poder de apreensão mental e, por consequência, possibilitou autonomia no fazer do estudante, no seu exercício prático de vida ao desenhar sua comunidade.

As respostas dos estudantes - tanto de várzea quanto de terra firme sobre o gostar de viver na comunidade - são significativas e expressivas de suas relações como o lugar de vida. Você gosta de viver na comunidade? Se gosta, por que?

"Sim. Gosto por quê moro nela desde quando me criei, mas não é somente isso que tenho a falar. O que eu gosto mesmo, é de estudar, rezar, brincar com meus colegas, na sala de aula, juntamente com as professoras. Com isso vou terminando as minhas pequenas explicações." ( $6^{\circ}$ ano - escola da água)

"Sim. Eu gosto da minha comunidade porque ela é muito importante na minha vida nela eu posso observar como é o meio-ambiente. Existe muitas pessoas importantes legais com a sociedade". ( $7^{\circ}$ ano - escola da água)

"Sim. Porque é bom viver na Comunidade como uma pessoa. Que é uma comunidade unida, todos se ajudam no que precisa pra comunidade. Uma comunidade unida jamais será vencida". ( $8^{\circ}$ ano - escola da água)

"Sim. Porque não existe muito barulho como de automóvel, carro, ônibus e outros. Na comunidade as pessoas vivem na paz e na bondade entre pais e filhos com qualquer ser humano vivem em união com seus próximos. Não tem o risco de ser matado e de ser roubado”. ( $9^{\circ}$ ano - escola da água)

Viver em comunidade é estar em convívio fraterno com todos os sujeitos construtores de espaços de significados. É se sentir seguro e protegido porque as relações comunitárias representam e transmitem paz. Nessa relação de convivência, renova-se a vontade dos aprendizes em querer, social e coletivamente, manter-se comunitariamente vivendo.

"Sim. Porque existe muitas famílias que são ótimas que se dão com todo mundo e que tem professores que ensino muito bem." ( $6^{\circ}$ ano - escola da terra e floresta).

"Sim. Porque as vezes ela é calma, tem pessoas que gostam de conversar. Tem lugares para frequentarem como bares, igrejas e etc. A Vila Amazônia é um lugar calmo, onde as pessoas trabalham para o sustento deles". ( $7^{\circ}$ ano - escola da terra e floresta)

"Sim. Eu gosto porque foi aqui que eu cresci com a minha família e assim sempre gostei dela. Tem muitas coisas divertidas, legais e nunca vou esquecer da minha comunidade. Aqui conheci minhas amigas que são muito legais, divertidas, muito importante para mim." ( $8^{\circ}$ escola da terra e floresta). 
Os alunos do $9^{\circ}$ ano não responderam esta e outras questões. Foi mantida a forma como os estudantes escreveram para não interferir no sentido do conteúdo da escrita.

As respostas expressam o sentimento de pertencimento de cada estudante e a relação de vida que possuem com o seu lugar de vida. Deixam clara a relação comunitária de viver e estar em comunidade. Demonstram o sentimento de identidade construída nas relações de convivência e a harmonia que os faz eternizarem o gosto por viver coletivamente, onde a ajuda mútua tem significado de vida e sobrevivência. A paz e tranquilidade são componentes importantes para a valorização do lugar seja de várzea ou de terra firme.

Nenhuma resposta foi dada negativamente, porque o negativo não se faz presente pela harmonia que paira no lugar. Isto não quer dizer que não há desentendimento pessoal. Há, mas tudo se resolve no lugar, através de diálogo. Na comunidade de Santa Maria de Vila Amazônia, há presença diária da policia militar - que mantém um posto em pleno funcionamento - pela comunidade apresentar um padrão de bairro da cidade de Parintins.

Quando foi perguntado se conheciam a sua comunidade, as respostas remetem o leitor a um universo repleto de significados de vida.

"Sim. Realmente conheço porque convivo nela. Quando vivemos nesta comunidade, posso explicar o porquê do conhecimento dessa comunidade, onde nascemos e vivemos que ao mesmo tempo é bem movimentada, onde temos as aulas mais avançadas, como bem ensino fundamental ao ensino médio e até computação com a nossa técnica, etc.". (6 $6^{\circ}$ ano - escola da água).

"Vou falar um pouco, sobre minha comunidade. Minha comunidade, é assim: é pequena, mas nela existe uma linda escola, uma igreja, casas, árvores e principalmente as pessoas que são os comunitários. E também o que eu acho importante em minha comunidade, é o lindo rio, que fica em sua frente”. ( $7^{\circ}$ ano - escola da água).

"Sim. Conheço a minha comunidade, tem poucas pessoas. Mas é uma comunidade de paz, porque todos os vizinhos são bons, porque um ajuda o outro; nunca vence a luta sozinho, vence sempre com a força da Comunidade”. ( $8^{\circ}$ ano- escola da água).

"Sim. Na minha comunidade as pessoas são a parte semelhantes pessoas. Sempre querem-se valorizar na sua forma como o povo de diversos tipos. A comunidade, ela é formada de pessoas adequadas. As pessoas todas se conhecem". ( $9^{\circ}$ ano - escola da água). 
Responder se conhece ou não a comunidade não é enumerar o que existe construído. Mostrar, sim, o sentimento que se nutre pelo lugar que representa a vida, estabelecendo apego a cada centímetro do chão que lhe fez crescer e de tudo que ajudou a construir como membro comunitário.

"A minha comunidade foi fundada com uma família de japoneses que transformou a nossa comunidade. Mais tem muitas casas bonitas mais de que eu pensava na minha vida". ( $6^{\circ}$ anoescola da terra e floresta).

"Minha comunidade tem lojas, tem posto de saúde para as crianças e adultos, para não ficarem doentes, minha comunidade tem o campo de futebol". ( $7^{\circ}$ ano - escola da terra e floresta).

"Bom, primeiro tem o banho que várias pessoas frequentam quando esta cheio. Depois tem as festas que várias pessoas de Parintins vem para ver como é. Tem igreja que dia de domingo as pessoas vão para lá. E tem a boate que vários dias tem". ( $8^{\circ}$ ano - escola da terra e floresta).

Nas respostas dos estudantes deste questionamento, já se evidencia um olhar muito diferente sobre o conhecimento de sua comunidade. Os estudantes da escola da terra e floresta, até pelo tamanho da comunidade e pela proximidade da cidade de Parintins, expressam muito de sua relação com o urbano. Já passaram a incorporar muito do modo de vida urbano, associado ao seu modo de vida rural. Quanto às respostas dos alunos da escola da água, mantém o sentimento de ser ribeirinho, expressando o seu modo de vida comunitária, apesar de terem contato com o modo de vida urbana. Esta resistência se deve ao distanciamento da comunidade do centro urbano.

Foi solicitado que descrevessem o que existe ao redor (entorno) de sua comunidade e fizessem a mesma descrição da organização da comunidade em estrutura física e social. As respostas a estas questões se complementam, confirmando o conhecimento que possuem sobre sua comunidade.

"O que posso descrever na minha comunidade. É que existem vários tipos de coisas importantes. Bem como os moradores. Como as casas das professoras, as matas, as hortas da escola, o telefone a antena do telão do tecnológico e outros mais. Com isso a organização da nossa comunidade até nesse instante tá contribuindo bem com a nossa estrutura física. $O$ que quero dizer com essas organizações da comunidade, é que estamos felizes com a nossa comunidade que está quase organizada, só não está bem organizada porque ainda falta o poço artesiano, o posto de saúde, a luz para todos". ( $6^{\circ}$ ano - escola da água) 
"Que existe ao redor da minha comunidade tem casas, árvores, frutas, animais e também capim, casas, igreja - isso existe redor em torno da nossa comunidade. A organização da minha comunidade está muito fundamental estrutura que é valorizado em uma modificação por causa das pessoas que valorizam ela e, socialmente, transformado pela divisão que é papel fundamental”. (7. Ano - escola da água).

"Existe ao redor da comunidade: campo de joga bola, telefone pra gente comunicar, mais rápido possível e muito vizinho. Casas de professores e muita floresta Amazônica, e muito animais domésticos, etc. Está muito legal porque as pessoas são muito boas e atenciosas e alegres. Com todo mundo que chegar para fazer alguma coisa por nossa organização física e social". ( $8^{\circ}$ ano - escola da água).

"De modo especial existe: a Igreja, a casa do professor, a casa da gestora, a sede da associação, o Colégio Tiradentes, o pavilhão, o barco e o campo de futebol, o telefone, a torre a antena do tecnológico e somente isso que existe em minha comunidade e outras coisas que Deus falta botar. Ela é organizada por pessoas de capacidade de estrutura física porque eles vivem". ( $9^{\circ}$ ano - escola da água).

Aflora em cada descrição a vontade de mostrar o quão é importante o que existe na comunidade para todos os comunitários. O quanto representa a casa de palha, de alvenaria ou de madeira. O importante é se sentir bem como agente ativo e participante da construção da organização do espaço socialmente construído.

"Que existe ao redor é casa de telha de alvenaria outra de palha. É quando está organizada algumas famílias e casas". ( $6^{\circ}$ ano - escola da terra e floresta).

"Existe ao redor de minha comunidade fazenda grande, o rio Amazonas, muitos lagos grandes e lagos pequenos. Sim, minha comunidade tem estrutura física sim porque tem posto de saúde, mercearias pequenas, lojas, escola para nós estudar". ( $7^{\circ}$ ano - escola da terra e floresta).

"Tem vários terrenos que tem gados para serem criado. Só em torno da Vila tem o rio Amazonas. Tem também vários barcos. A Vila, esta estruturada no caso do asfaltamento para algumas ruas porque tem ruas que não tem asfalto. Socialmente no caso que já tem várias associações de moradores". ( $8^{\circ}$ ano - escola da terra e floresta).

Nota-se o quanto os estudante precisam aprender a descrever o lugar que vivem. Expressam com muito mais detalhes nos seus desenhos. Quanto à organização da estrutura física e social, dentro de suas limitações de conhecimento demonstram a compreensão que possuem. $\mathrm{O}$ que ficou percebido que lhes falta mais leitura geográfica, ou seja, falta melhor fundamentar com conceitos geográficos para que possam compreender todo processo de 
organização existente na comunidade. Isto não invalida suas respostas. As respostas são cheias de significados e saberes.

Entrando, na escala maior, é uma tentativa de refletir sobre o quanto concebem seu lugar de vida todos os questionamentos foram direcionados para a casa. Serão usadas as respostas de alguns estudantes, representando todas as outras respostas, até porque em alguns detalhes elas são parecidas. Como é sua casa? De que é feita sua casa? Descreva-a. O que existe no terreiro de sua casa? Descreva o lugar que você mora.

"A minha casa é bonita bem grande. Tem 17 metros de comprimentos com 8 de largura. Toda rodeado de varanda- com isso tem 220 folhas de telhas. Ela também é pintada de azul e branca. Minha casa é feita de madeira coberta de telha e pintado de azul-claro e tem cozinha e um quarto. Existe muitos capins e muitas árvores. No lugar tranquilo em muitas pessoas podem ouvir os pássaros os animais cantarem”. (Aluno (a) - $6^{\circ}$ ano - escola da água).

\section{DESENHE SUA CASA E O QUE EXISTE AO REDOR}

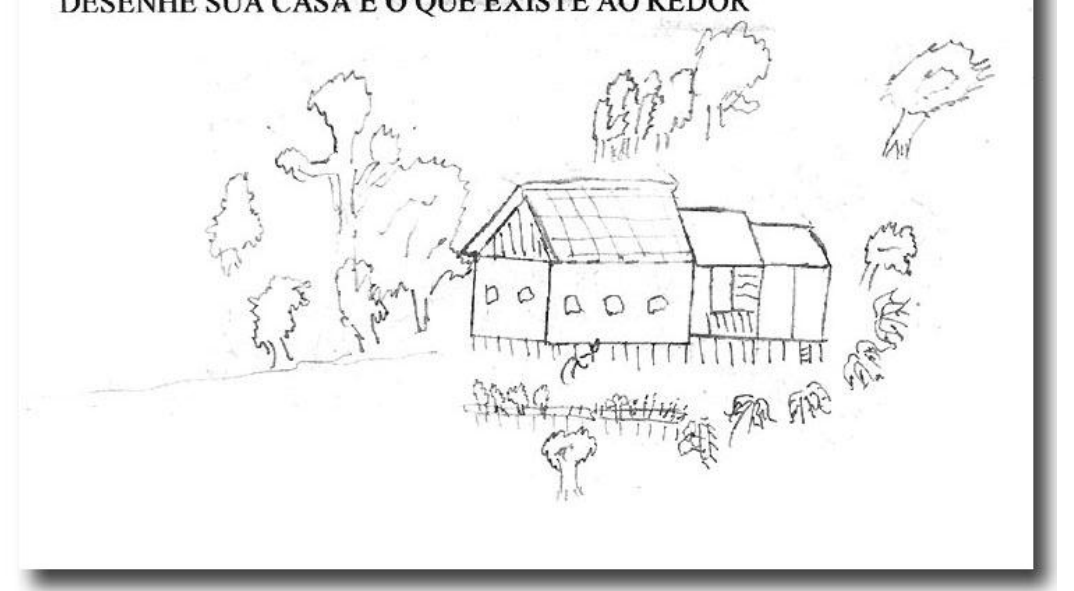

Figura 36 - aluno da escola da água 
"Minha casa e tem quarto, tem cozinha, móveis, armários, cama e também tem pátio, janela, varanda e também a minha casa é muita coisa boa para mim. De madeira, telha brasilit. Existe capim, plantas, árvores. Eu moro no rural do Menino Deus" (aluno (a)- $7^{\circ}$ ano - escola da água).

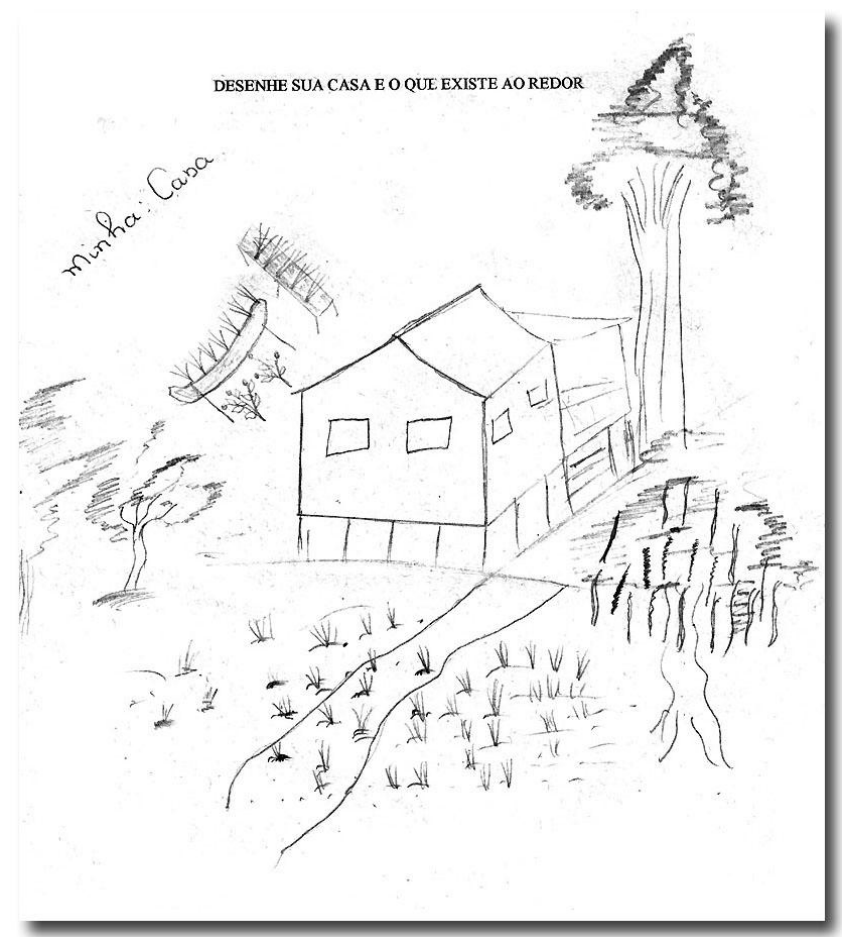

Figura 37 - aluno da escola da água

“A minha casa é grande e bonita só que ainda não esta tudo terminada. A minha casa ela também é feita de telha esteio, taboa, parede sobre telha, prego ou também parafuso. Existe várias coisas no meu terreiro, tem mato, tem sapo, tem galinha, tem planta. Lugar onde eu moro é na comunidade Menino Deus do Itaboraí do Meio. Por lugar onde a gente mora é muito importante para todos os comunitários que vivem nela". (aluno (a) - $8^{\circ}$ ano - escola da água).

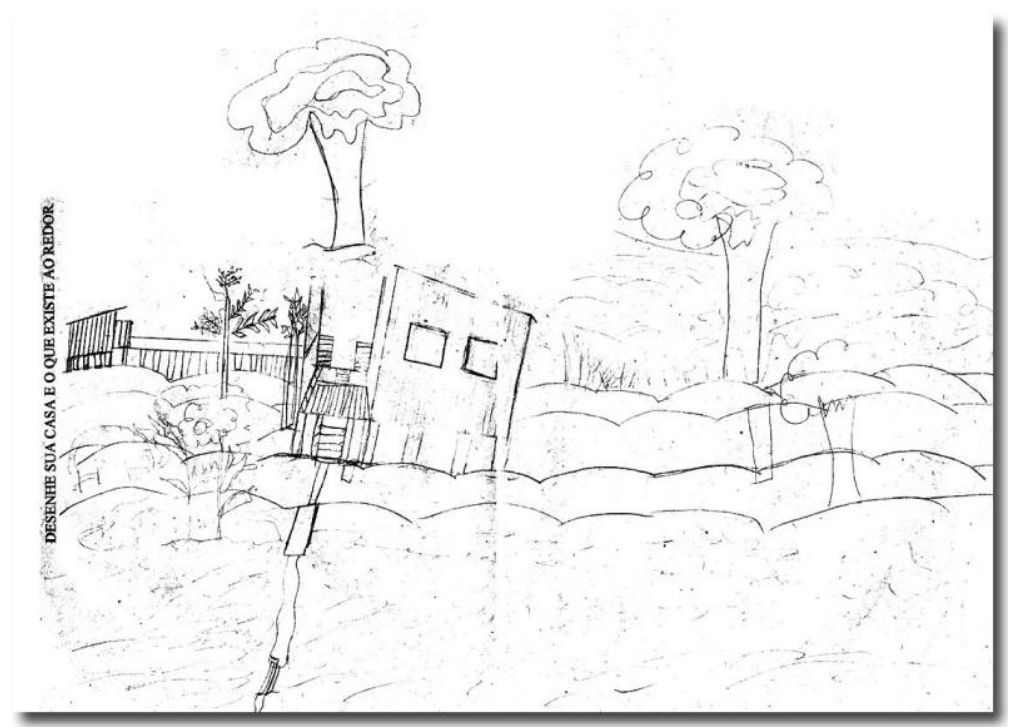

Figura 38 - aluno da escola da água 
"A minha casa é de assoalho alto, com varanda tem 3 quartos e cozinha e pintada de cor verde e branca e fica de frente para o rio. É feita de madeira e coberta de telha brasilite. Existem vários tipos de árvores e pequenas criações de animais, plantação de juta e malva. Eu moro no terreno Santa Teresa situada a margem a esquerda do rio amazonas lado sul com 60 metros de frente e com 1500 de lado”. (aluno (a) - 9ªno - escola da água).

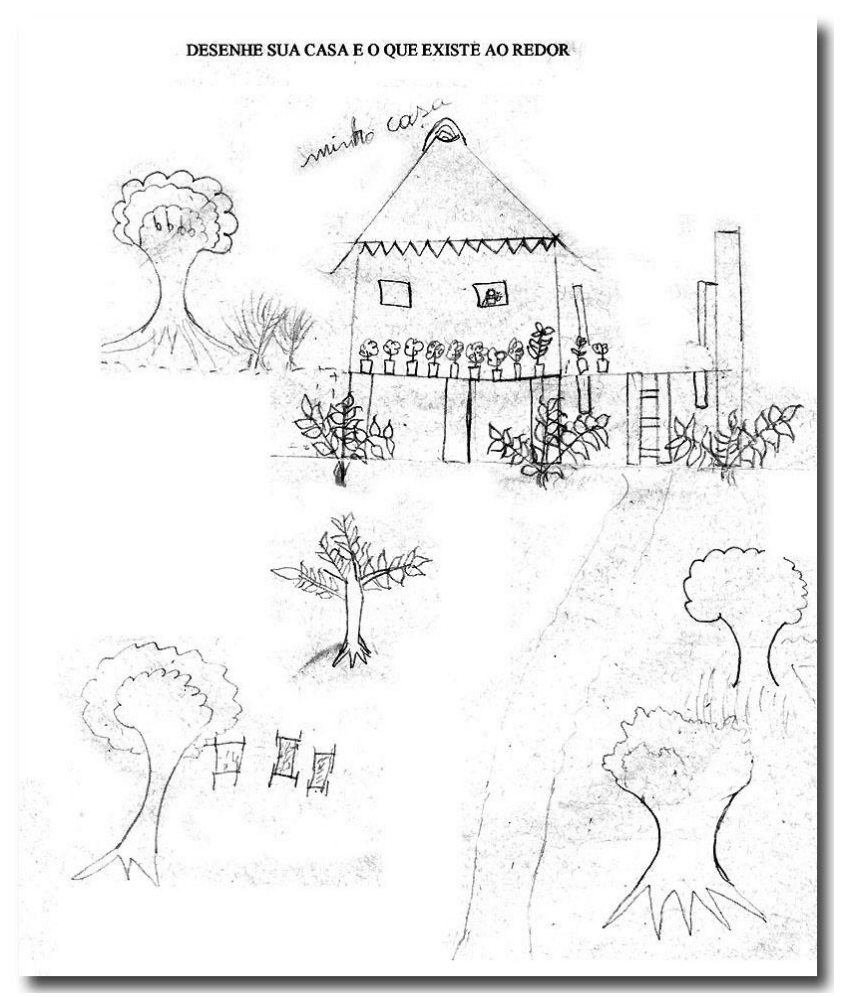

Figura 39 - aluno da escola da água

A casa é o lugar que mais aproxima os sujeitos e mantém uma estrutura social de convivência, representando um ambiente de aprender constantemente as lições de vida e de receber a preparação de maturação para viver em sociedade, convivendo com os conflitos e sabendo se posicionar com criticidade diante das imposições de injustiças sociais. 
"Minha casa é maravilhosa, é grande, é coberta de telha e rodeada de talba e plástico. Minha casa é feita de telha redoada de talba e plástico. Planta, árvore, campo de jogar bola. O lugar onde eu moro é cheio de planta, casa e muitas famílias". (aluno (a) - $6^{\circ}$ ano- escola da terra e floresta).

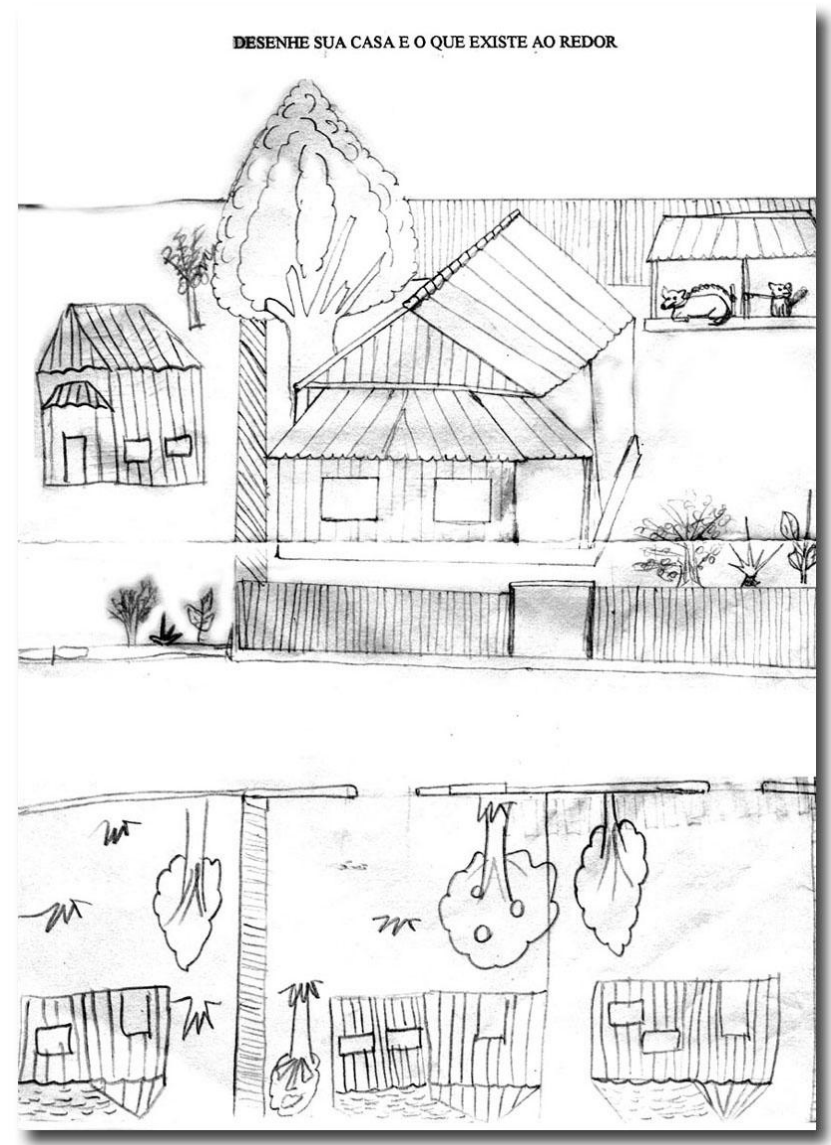

Figura 40 - aluno da escola da água 
"Minha casa é pequena porque meu pai não terminou de construí, eu e meus irmãos toda nossa família ficam na comunidade. Minha casa é feita de alvenaria. Moro na casa da minha tia. Muitas arvores, mangueira, quiabeira, jambeiros, acerola no meu quintal existe essas. $O$ lugar que eu moro é muito tranquilo, onde eu moro na comunidade". (aluno (a) - $7^{\circ}$ ano escola da terra e floresta).

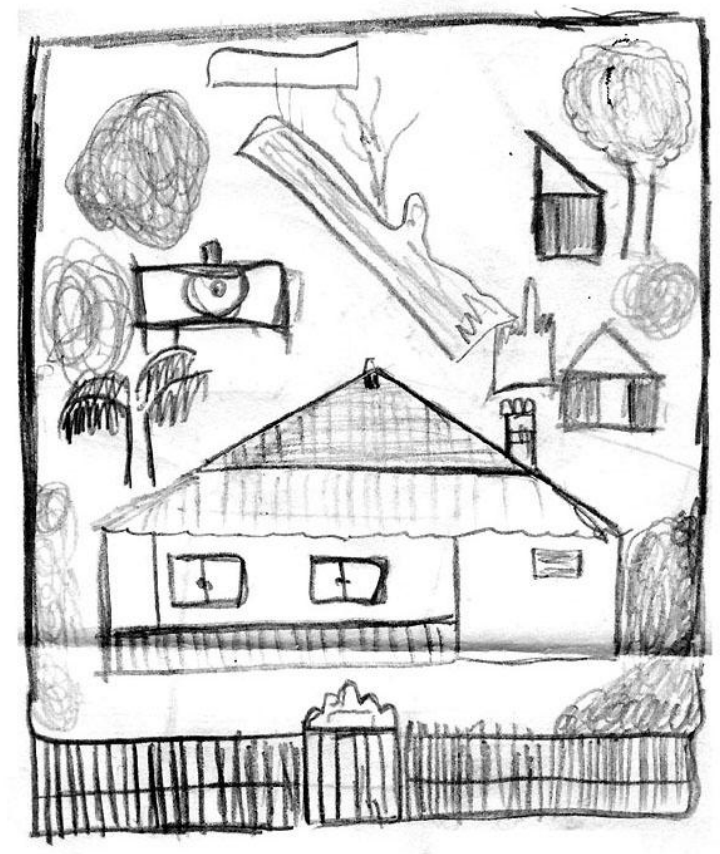

Figura 41 - aluno da escola da água 
"A minha casa é muito grande, na frente ela é pintada de ver de e amarelo. Ela tem várias flores na frente, o telhado dela é de barro. Existe árvores de ingá, tem frutas. Tem também um galinheiro, para as galinhas". (aluno (a) - $8^{\circ}$ ano - escola da terra e floresta).

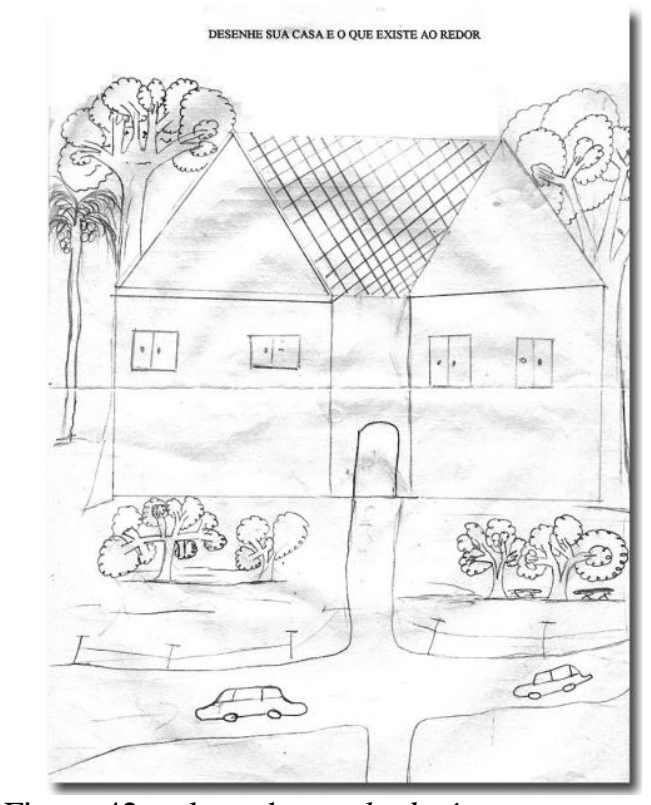

Figura 42 - aluno da escola da água

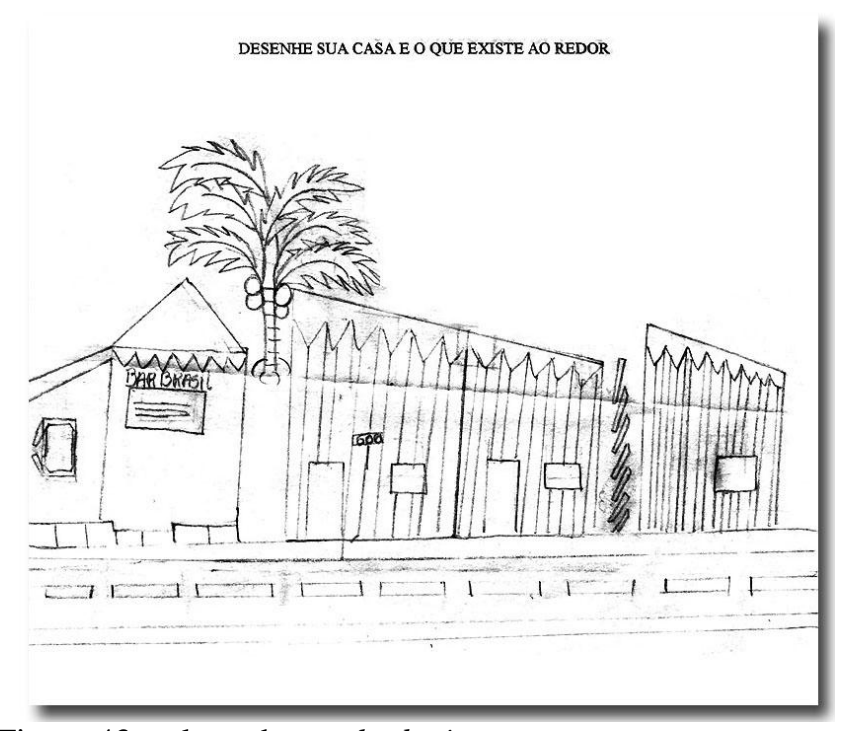

Figura 43 - aluno da escola da água

É perceptível o sentimento de pertencer ao lugar. O gostar traduz a vontade de permanência e fortalece as relações familiares e culturais da comunidade. A família é sempre colocada em primeiro plano nas relações de convivência e de construção de convívio social. Esta forma de se sentir na comunidade e no convívio social pode ser base de toda aprendizagem, que poderá ser ressignificada se o ensino de geografia proporcionar este fortalecimento.

Os desenhos reforçam o que foi escrito pelos estudantes em suas respostas aos questionamentos sobre a sua casa. Estes desenhos dos alunos da escola da terra e floresta são demonstrativos de suas percepções espaciais do que existe próximo e das suas relações de convivências.

Partindo deste parâmetro ou dos desenhos, pode ser dimensionado o quanto o estudante aprenderia em geografia se fosse exercitado continuamente seu saber e seu aprender. 
A delicadeza do desenho é a expressão do quanto significa o lugar de vida dos estudantes das escolas ribeirinhas. Entendem o lugar e traduzem em saberes por que se sentem e são parte integrante, extraindo do seu eu toda sua expressão de vida, na representação do espaço social de vivência comunitária.

Quando inquiridos sobre a escola, as respostas não fogem à regra do que já foi respondido e mantém aflorado o sentimento de sua identidade cultural. O que é escola? Você conhece sua escola? O que leva a conhecer sua escola? Como você vive na escola? Como a escola contribui na melhoria de sua vida?

"A escola que faz a gente se educar, aprender, ensinar que tem mais alunos, jovem, adolescente, crianças. Eu não conheço muito bem porque quando em vim para a Vila Amazônia eu não sabia onde ficava a escola si era pra frente ou pro centro e o transporte. Aprender se educar, estudar e outras mais com os professores e responsável. Muito bem educada com todos os meus colegas, professores, funcionários". ( $6^{\circ}$ ano - escola da terra e floresta).

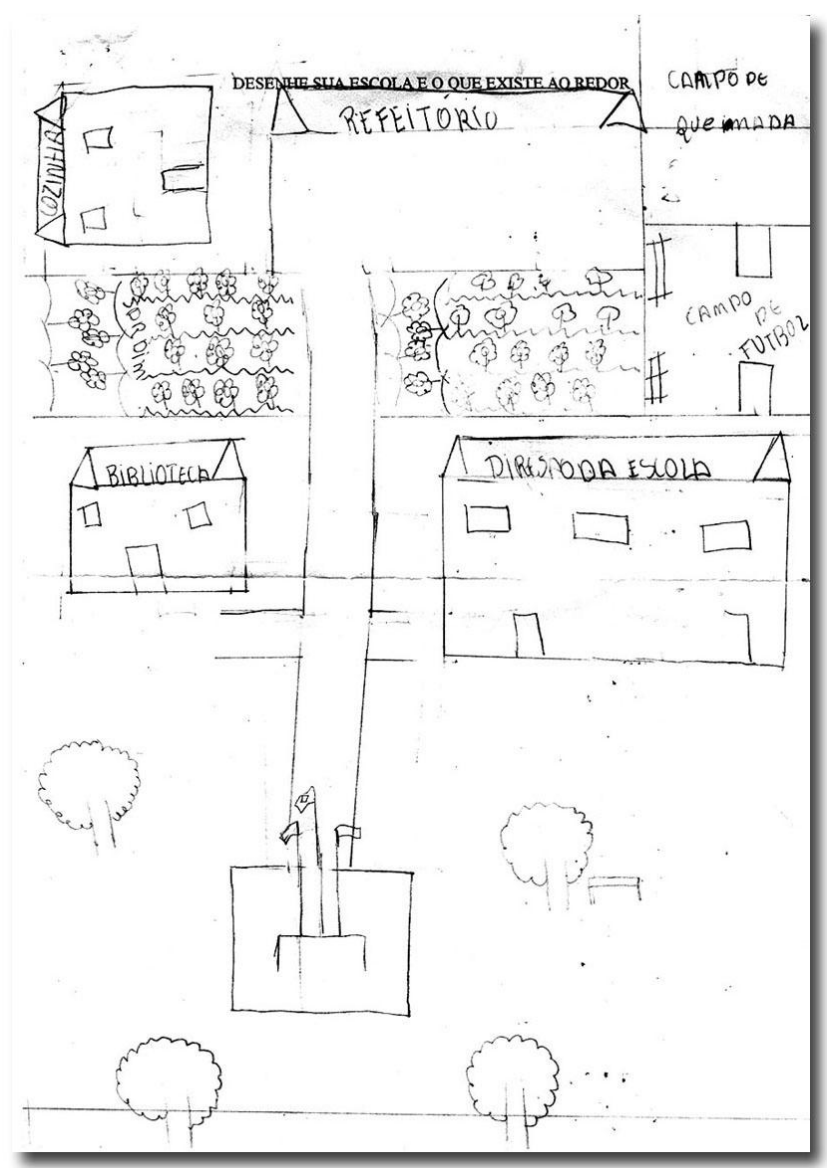

Figura 44 - escola da terra e floresta - Tukasa Uetsuka 
"A escola é um lugar onde as pessoas aprendem a estudar e aprender para ser alguém na vida. Sim, conheço sim bem minha escola. Leva a conhecer muito escola porque ela é divertida. Na escola eu vivo muito bem porque a diretora é muito para a nossa escola, os professores são muito legais". ( $7^{\circ}$ ano - escola da terra e floresta)

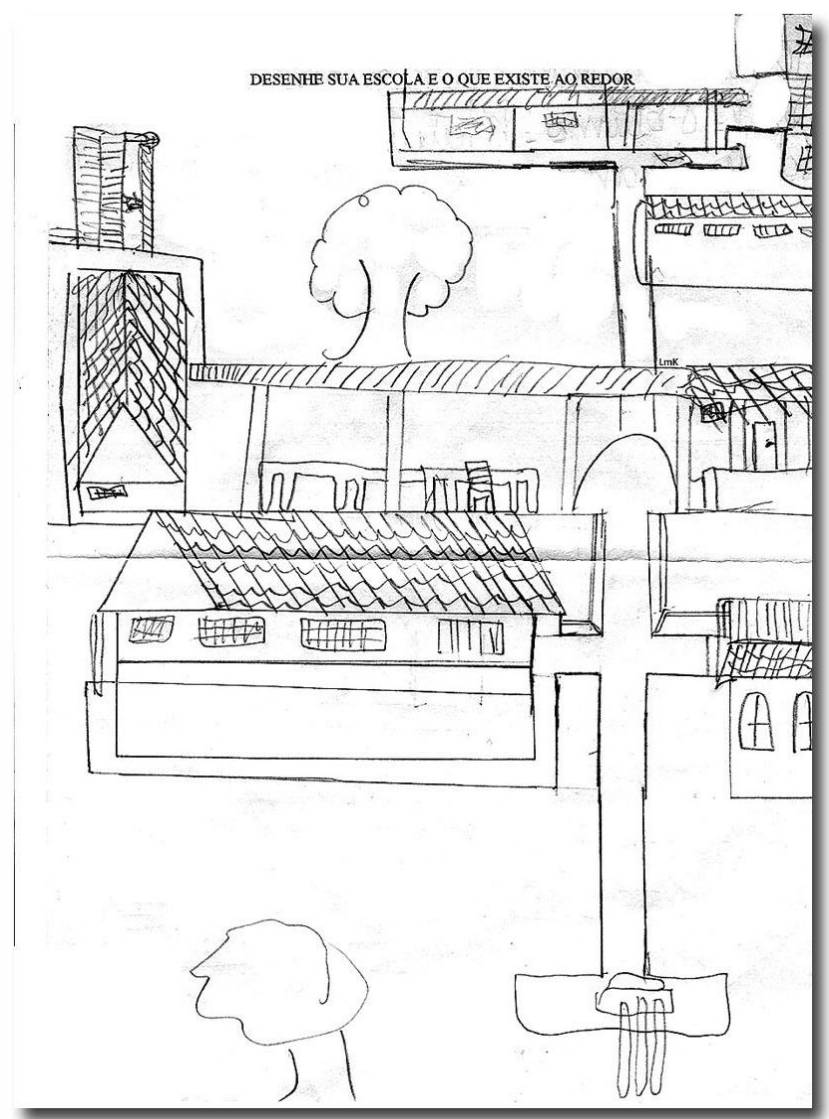

Figura 45 - escola da terra e floresta - Tukasa Uetsuka 
"Onde as pessoas estudam e aprendem sobre todas as matérias na escola. Sim, os alunos e os professores, para ver se eles respeitam os alunos. Eu vivo bem comportada, prestando atenção nas aulas. Para mais tarde eu ensinar para outras pessoas. Contribui dando boa educação, esporte e lazer". ( $8^{\circ}$ ano - escola da terra e floresta)

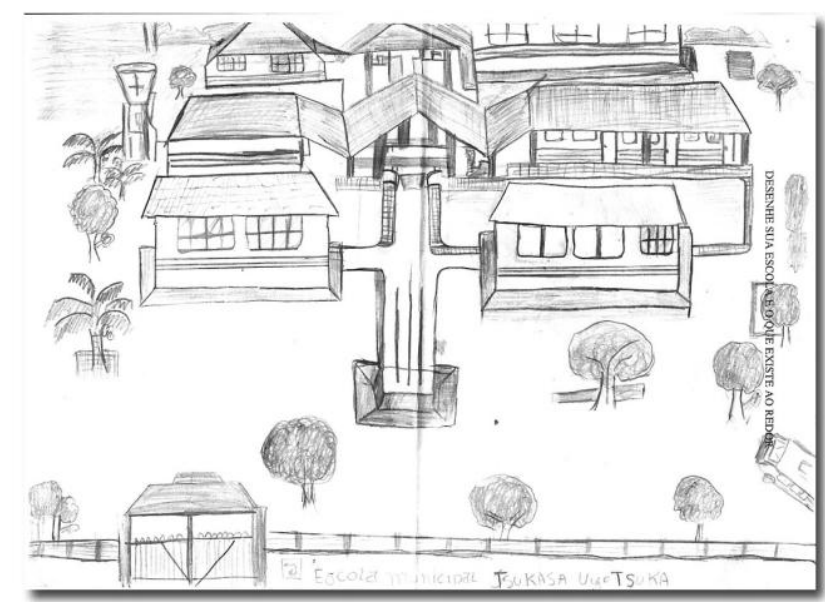

Figura 46 - escola da terra e floresta - Tukasa Uetsuka

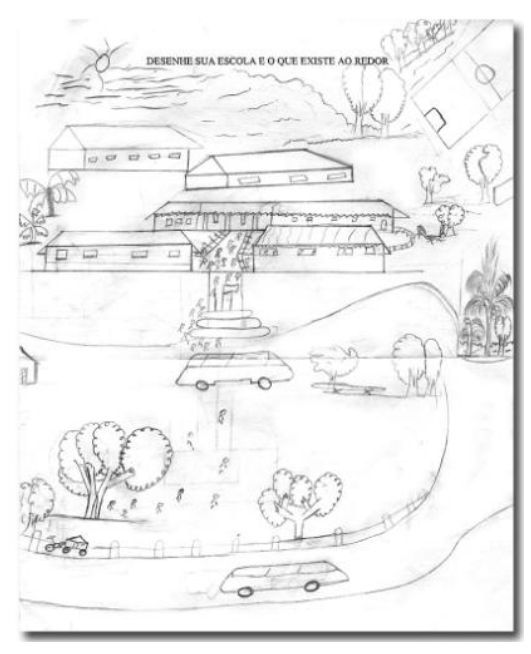

Figura 47 - escola da terra e floresta

Escola não é o prédio escolar. Este é um lugar que representa fisicamente a escola e que se torna guardiã da vida de todos os sujeitos envolvidos no processo ensinoaprendizagem. Mesmo assim, o espaço de construção de conhecimento não é apresentado aos estudantes e, por não ser, passa ser mais lugar comum. A secretaria da escola representa o lugar da punição e geralmente, quem é encaminhado, recebe suspensão. A diretoria, sala do gestor da escola, representa punição severa, transferência.

O prédio escolar deve ser apresentado aos estudantes para que possam perceber a organização espacial e a funcionalidade do prédio e o que representa cada ambiente, além da sala de aula. A escola resulta de inúmeras relações socioeducativas, mantenedora de processos de ensino-aprendizagem que transformam o ser aprendente, em sujeito ativo socialmente. 
"Escola é onde aprendemos a ler e a escrever e é onde eu vou terminar de estudar. Sim. Ela é a explosão da nossa vontade porque foi elaborada pelos nossos representantes (os políticos que o povo elege pelo voto), reunidos em assembleia nacional constituindo. Vamos conhecer um pouco do que diz a nossa constituição? Constituindo objetivos fundamentais da República Federativa do Brasil. Construir uma sociedade livre justa e solidária, garantir desenvolvimento nacional". ( $6^{\circ}$ ano - escola da água).

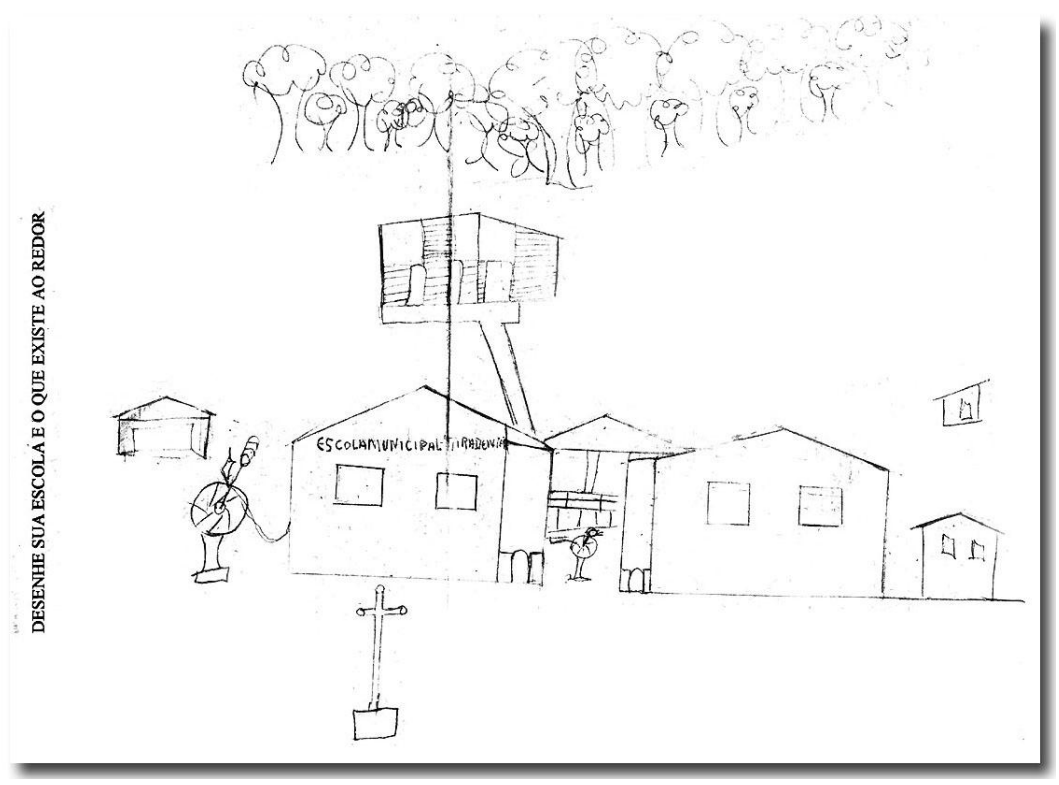

Figura 48 - aluno da água - Tiradentes 
"Estabelecimento público onde se trabalha a educação. Fazem parte desse estabelecimento, professores, alunos e outros funcionários públicos: merendeiros, auxiliares de serviços gerais. Sim. Porque ela é uma escola muito agradável para os comunitários. Chega da nossa escola e também vem da inteligência, categorias na nossa criatividade. A escola leva a conhecer várias coisas como aprendizagem. Com a nossa professora aprendemos várias coisas para o nosso futuro. Vamos conhecer um pouco do que diz a nossa constituição? Constituindo objetivos fundamentais da República Federativa do Brasil. Construir uma sociedade livre, justa e solidária, garantir desenvolvimento nacional". ( $7^{\circ}$ ano - escola da água).

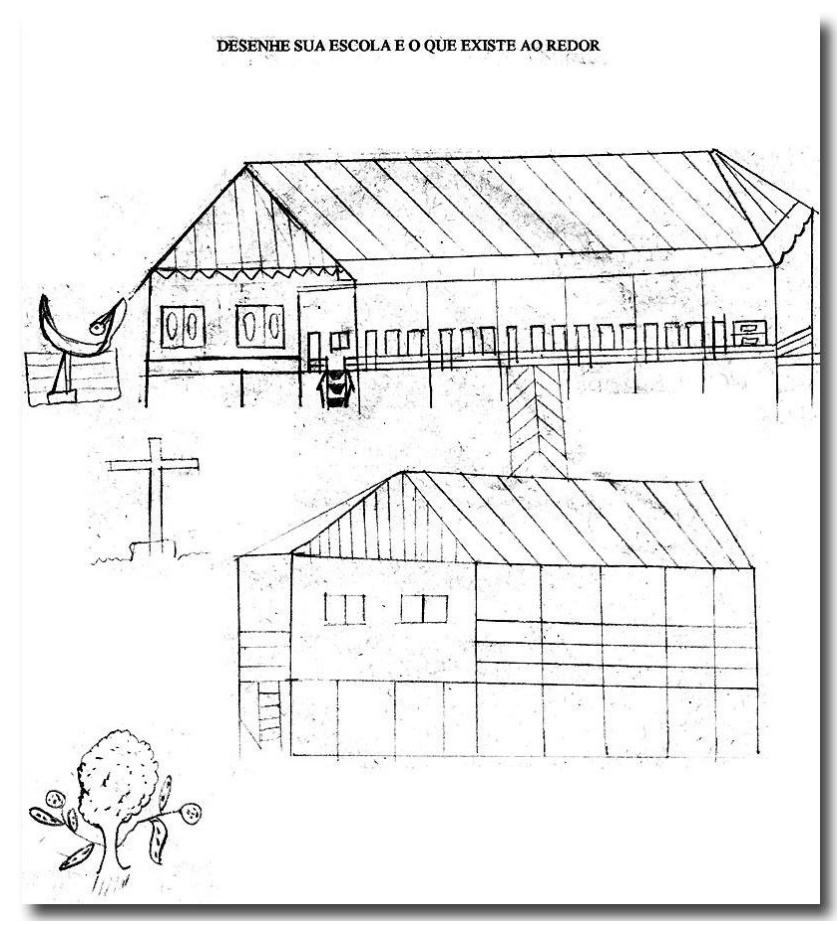

Figura 49 - aluno da água - Tiradentes 
"Escola é uma casa onde nos aprendemos muitas coisas interessantes porque agente aprende a ler e escrever então por isso que a escola ensina os alunos. Eu conheço a escola através do estudo que ela acolhe agente, para estudar e aprender, que é bom pra todos nós. Leva através de toda parte onde nos aprendemos nela, por ela, é nossa segunda casa onde os alunos estudam por isso que é comunidade. Eu fico atrás indo estudar e fazendo a tarefa que o professor manda a gente responder. Se os alunos não responder, a gente não pega nota então por isso que a gente vive na escola. A escola contribui por várias partes onde os alunos aprendem ler a escrever. Então por isso que a escola dá melhoria para cada aluno que quer aprender". ( $8^{\circ}$ ano - escola da água)

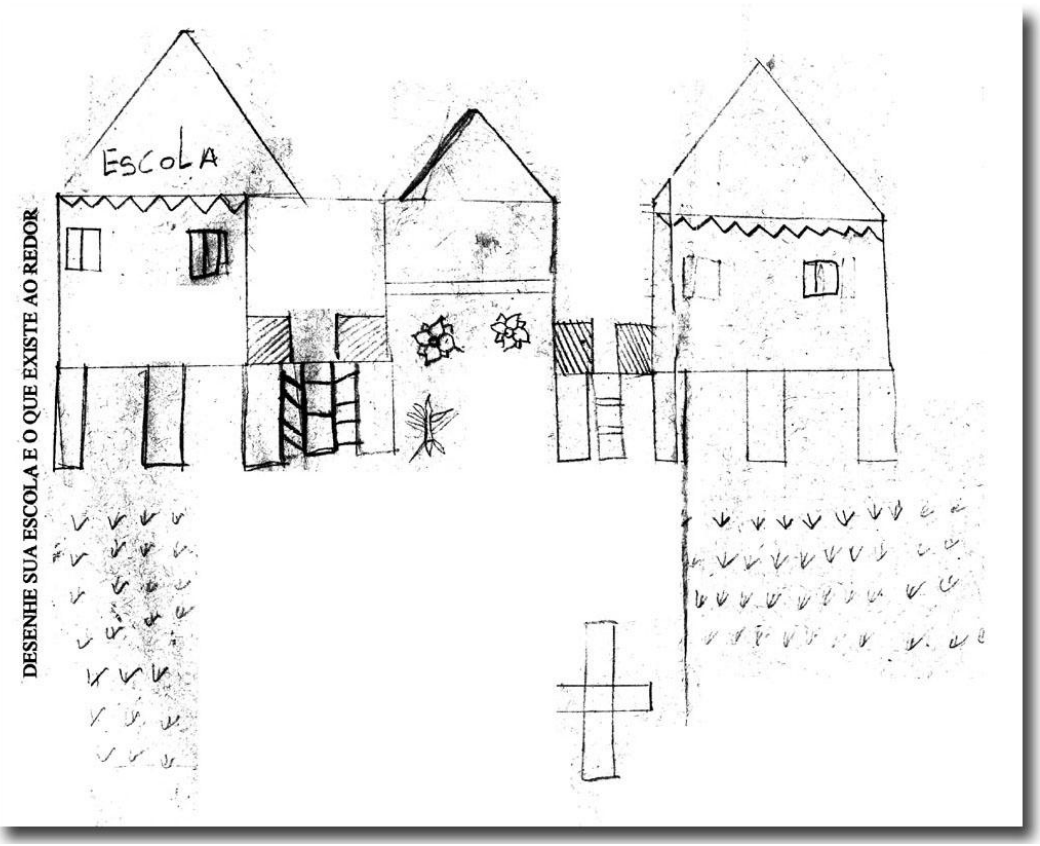

Figura 50 - aluno da água - Tiradentes 
"A escola é um grupo de professores e alunos. Sim. Conheço ela: tem 5 salas, secretaria, merendeira e a biblioteca feita de madeira. O bom interesse, as perguntas que fazemos, ser bem interessado, ouvir o que as professoras falem, ser educado, etc... Professores e os meus colegas, às vezes, eu levo um pouco na brincadeirinha. Recebendo a Bolsa-Escola, a bolsa bem que ela ajuda bastante os alunos, a comprar nossos materiais, tudo que precisamos". ( $9^{\circ}$ ano - escola da água).

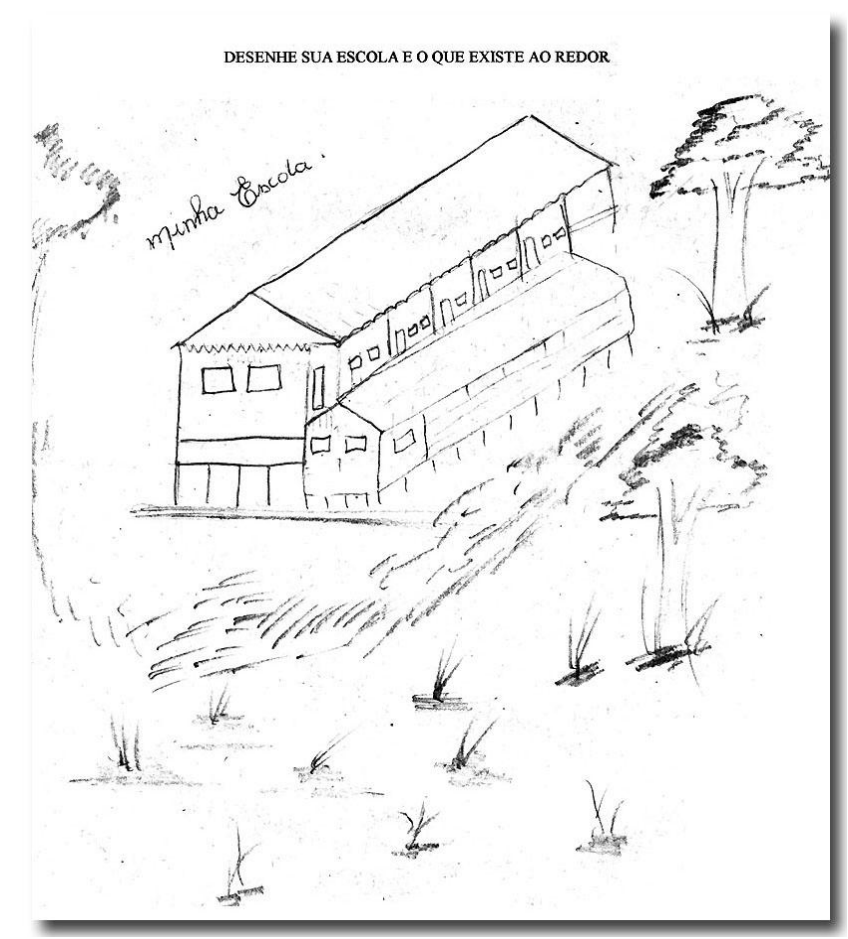

Figura 51 - aluno da água

Para os estudantes da escola da água, da terra e floresta - a escola representa não só a oportunidade de aprender. Representa mudança de vida e de comportamento. Representa a oportunidade de crescer intelectualmente e conquistar objetivos da vida pessoal.

Nas respostas que foram dadas, fica evidenciado o que representa a escola para cada estudante e a oportunidade que é estabelecida pelo conhecimento no projeto de vida de cada sujeito aprendiz.

O sentimento nutrido pela escola é projetado nas representações gráficas, demonstração de quem aprende continuamente exercitando mentalmente o que percebe na convivência de espaços sociais e educativos.

Os desenhos representam o real do prédio escolar. Os detalhes de cada prédio e o do existente no entorno mostram o quanto cada estudante guarda na sua memória o que observa na convivência diária. 
Foi solicitado que desenhassem a sua escola. A representação que fizeram, dimensiona o espaço socialmente construído. Este lugar foi projetado para ser uma escola agrícola, com sistema de internato, onde o estudante aprenderia para ajudar seus pais nas suas atividades agrícolas ou agropecuárias. O projeto foi abandonado e somente na década de 2000, voltou a funcionar como escola regular.

Os desenhos dos estudantes da escola da água ganham representatividade espacial e social, resultante do exercício mental de reproduzir o percebido a partir do vivido.

Representação cartográfica ou gráfica? Os desenhos são bastantes instigadores e reveladores dos pensamentos projetados no papel e encaminham reflexões acerca da realidade escolar. Cada desenho é uma demonstração de saberes geográficos adquiridos nas relações cotidianas. Estas representações é o entendimento que possuem da geografia como um bem social, que permitem o estudante a fazer exercício de criatividade, explorando seu lado artístico.

$\mathrm{Na}$ invisibilidade de cada desenho, é possível ver a leitura geográfica do espaço de aprendizagem. Fica claro que a geografia ou a cartografia poderá conduzir às leituras das realidades presentes nas comunidades ribeirinhas.

Avançando na compreensão da geografia nas comunidades ribeirinhas e procurando refletir sobre o currículo e o ensino de geografia e o reflexo de toda aprendizagem na vida do estudante, foram feitos vários questionamentos para ver o quanto de conhecimento sobre lugar cotidianamente vivido, conhecem:

O que é várzea para você? O que existe na várzea? O que é terra firme para você? O que existe na terra firme? Qual a diferença entre várzea e terra firme? O que é rio para você? O que você faz no rio? O que é lago para você? O que você faz no lago? O que é ilha para você? Explique como se forma a ilha?

As questões formuladas são condutoras de verificação do grau de conhecimento que cada aluno detém sobre aspectos particulares da Amazônia. 
"As várzeas são os terrenos baixos juntos aos grandes rios de águas barrentas que ficam inundadas na época das cheias. A várzea é justamente fértil porque a cada enchente que dura cerca de seis meses, os rios depositam sobre ela restos de animais e vegetais que adubam o solo. As terras firme são os terrenos mais elevados, livres das mudanças causadas pelas cheias dos rios. Os igapós são terrenos permanentemente alagadas pelos rios de águas pretas. A cor escura desses rios decorrem da forte dissolução de um ácido proveniente da decomposição de matéria orgânica vegetal que recobre os chãos das florestas. Na terra firme tem capivara anta e onça. A planície do rio Amazonas é uma faixa de terras baixas que acompanha o rio Amazonas e seus afluentes inclusive a ilha de Marajó. Nela destacamos os seguintes menus ou de grandes terras firmes, várzeas e igapós. Rio é uma fonte de vida e é onde se encontra vários tipos de peixes. O fenômeno ocorre quando as águas da maré crescente procuram invadir o terreno enquanto isso se opõe com grande resistência a massa fluvial provocando uma grande onda que com um grande estrondo, pode ser ouvida há muitos quilômetros de distância. Enquanto o mundo valoriza a floresta em pé, o Brasil parece valorizar a floresta no chão. E a Amazônia, objeto de muitas polêmicas, é protesto diante do projeto de modificação do código florestal, como esta se comportando. A Amazônia dá o troco na bancada ruralista e aos interessados em diminuir a floresta para alavancar os negócios na agricultura, os projetos de desenvolvimento prioriza dois lados. O que a gente faz no lago, a gente pesca, para a nossa comida, a gente pesca para gente ganhar nosso dinheiro. A ilha é um topo de um morro ou montanha submarina que emergiu e ficou acima do nível do mar. A superfície terrestre é muito irregular, isto é, apresenta diferentes formas. A essas formas damos o nome de relevo. Quando falamos em relevo, devemos levar em consideração tanto o relevo da superfície como o relevo submarino. O relevo da superfície se encontra acima do nivel do mar, o relevo submarino se encontra abaixo do nível do mar". ( $6^{\circ}$ ano escola da água)

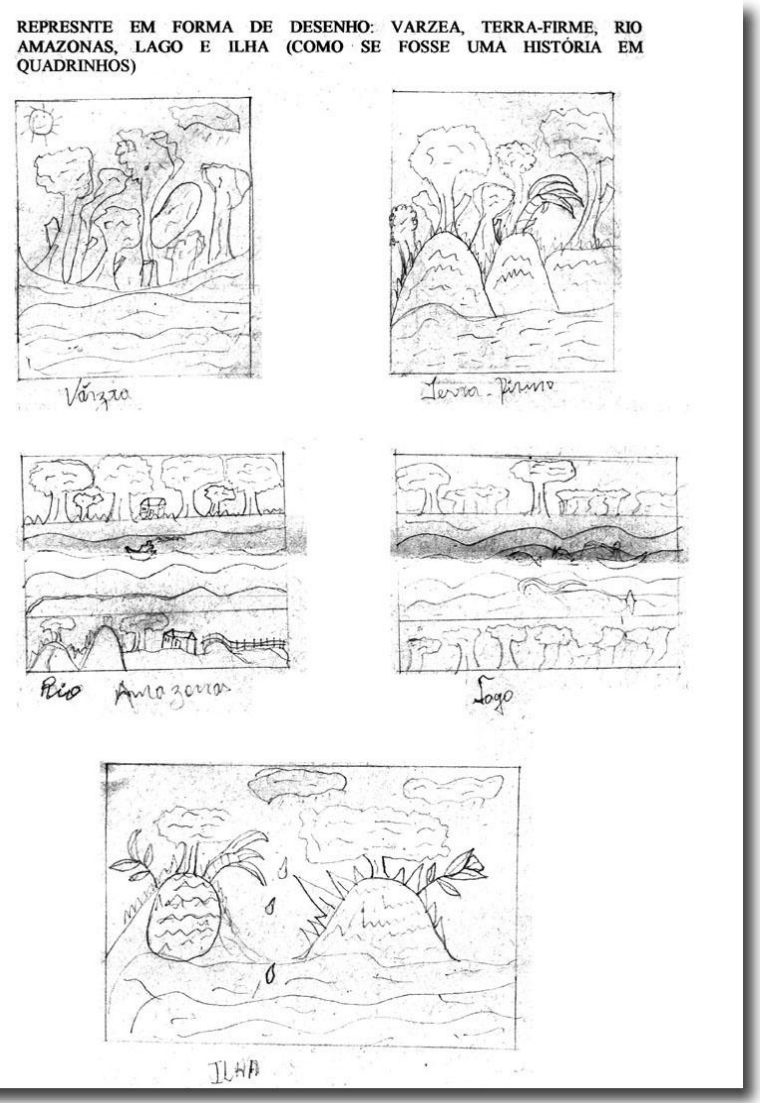

Figura 52 - aluno da escola da água 
"A várzea é extremamente fértil porque, a cada enchente que dura cerca de seis meses, os rios depositam sobre ela restos de animais e vegetais que adubam na época das cheias. A várzea é constatada pela presença pela presença de grandes números de pássaros e animais aquáticos como, jacarés, peixe-boi, tartaruga e outros animais que ali vão em busca de alimento para homem. As terras firme são os terrenos mais elevados livres das mudanças causadas pelas cheias dos rios. Nas terras firmes tem matas, laços, entradas, rios, lagos, igarapés, riacho e etc. Na várzea costumam cair terras, vai no fundo tem varias tipos de caça. Na terra firma não caem terras, não vão no fundo os tipos de caça que na várzea tem na terra firme não tem. Os rios são cursos de água doce que correm de terreno baixo para os terrenos altos ate desaguarem num outro rio. No rio nos pescamos vários tipos de peixe como peixe liso, peixe de escamas e dos rios no tempo da piracema que as pessoas pescam. Lago é um poço de água que nele existe em vários tipos de peixe e animais. No lago as pessoas ponham a malhadeira para pegar peixes, quando pegamos peixe fazemos o almoço para aguentar ate a tarde, depois que pescamos peixes, os peixes pegam são transportados por pessoas que pescam. A ilha é um torrão de terras altas que ficam no meio dos rios ou igapós. Para mim a ilha é formada por terras altas e matos, pessoas que vivem nas ilhas". ( $7^{\circ}$ ano - escola da água)

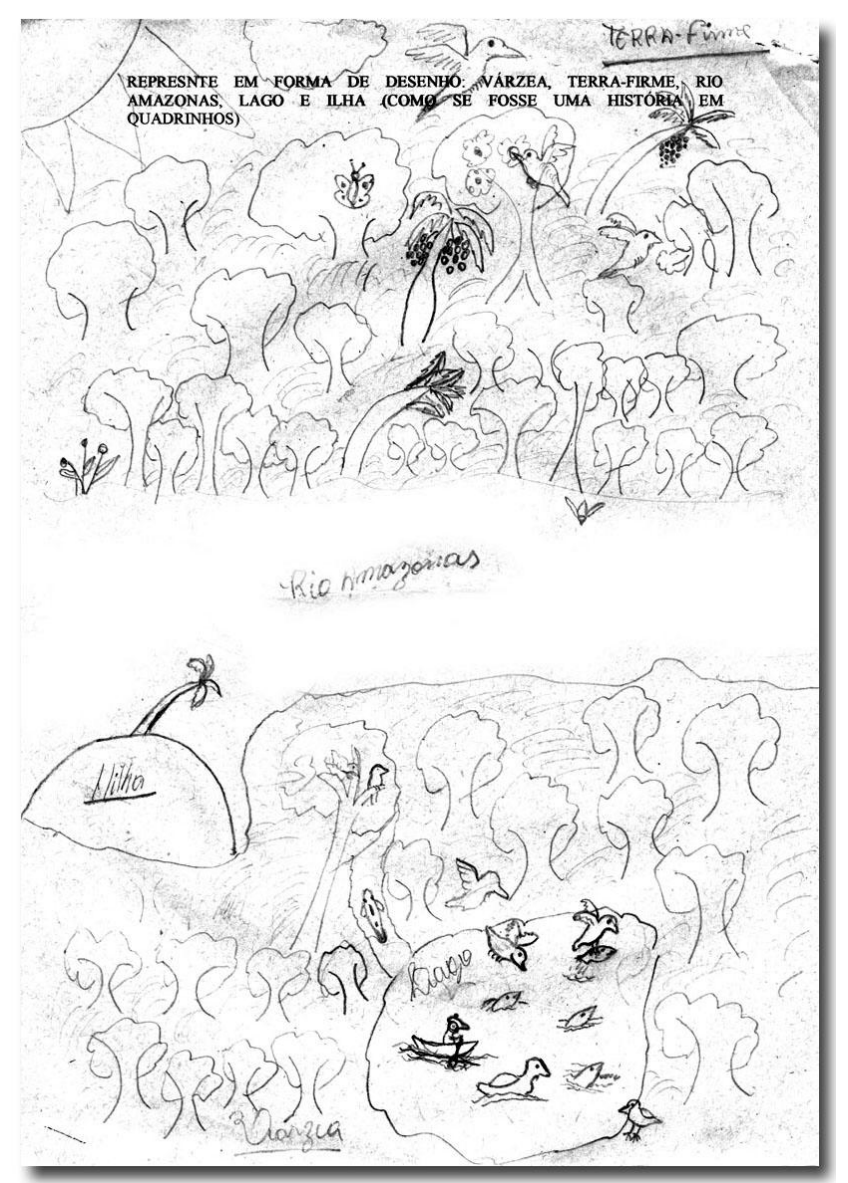

Figura 53 - aluno da escola da água 
"Terreno baixo plano e feito nas margens de água de um curso da água. Existe casa pássaro, animal, gado, cavalo, cachorro, tem lama, carapanam. Terra firme é para mim porque na terra firme tem vários tipos de coisa onde agente possa morar. Existe casa, cachoeira, planta, tem animal como onça, capivara, curupira. Por várzea, é terreno plano e onde vai no fundo, então por isso que tem a diferença entre várzea e terra firme: é uma terra mais alta onde não pode ir no fundo por que ela é mais alta que a várzea. O rio é importante para a sociedade humana como fonte de água, navegações, lazer, irrigação, alimento, isto é, ele produz águas limpas para a sociedade. As pessoas, quando não tem nada para comer, então elas são obrigadas a pescar no rio, para sua família se alimentar todos os dias. $O$ lago é onde nos pega nosso alimento, então por isso que o lago é importante para cada um de nós. A gente põem a malhadeira no lago e depois vai, puxa peixe quando dá aquele minuto. Eles só vem ver a malhadeira se já tem seu alimento preferido e agradecem a Deus que deu seu alimento. As ilhas são porções de terras emersas cercadas pelas águas de um oceano, mar, rio ou lago. Elas podem ter pequenas ou grandes dimensões. A várzea é um ecossistema complexo, com imensa riqueza biológica, passível de apropriação humana. Também são áreas periodicamente inundáveis por ciclos anuais regulares de rios de água branca, ricas em sedimentos. A várzea é uma área que oscila uma fase terrestre e outra aquática, portanto, comporta organismos terrestres e aquáticos, adaptados à uma alteração. A ilha se forma de terras extensas com continente e água cercada por todos os lados". ( $8^{\circ}$ ano - escola da água).

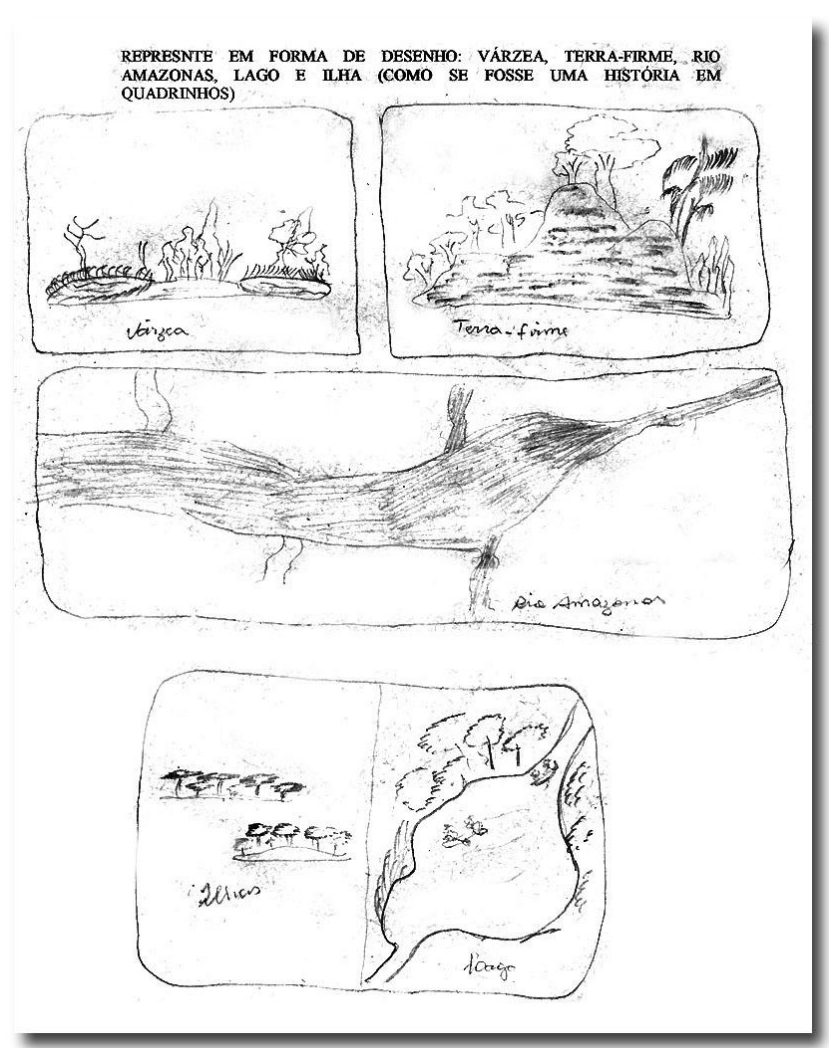

Figura 54 - aluno da escola da água 
"É o ministro de ensino coletivo, entre os alunos e professores e pessoas a escola. São os ramos do saber, é o estabelecimento público, qualquer forma compositivo de pessoas que promove o estudo, etc. Totalmente eu conheço escola como um lar que eu admiro tanto de aprender muitas coisas importantes. Eu sou um aluno educado, respeito minha professora, gestora, secretaria e outras pessoas. Eu me interesso nos meus assuntos, não gosto de bagunça, só brinco nas horas precisas, na hora do estudo só bastante interessado. Recebendo a Bolsa-Escola; , a bolsa, bem, ela ajuda bastante nos alunos a comprar nossos materiais, tudo que precisamos. A várzea é um lugar onde eu minha família moramos e cultivamos plantações e criações domésticas. Existem plantações de alimentos para os seres humanos $e$ frutas para os peixes e criações de animais. A terra firme é um lugar onde levamos as nossas criações de animais e onde fazemos pequenas plantações de capim para os animais. A diferença é grande porque a várzea vai no fundo e a terra firme não vai. A diferença é grande porque a várzea vai no fundo e a terra firme não vai. Os rios são cursos naturais de água doce que correm sobre os continentes e as ilhas, eles são muitos importantes para a sociedade humana, pois fornecem água e alimentos, são utilizados para geração de elétrica, permitem a navegação e a irrigação de áreas agrícolas e servem para o lazer. Eu tomo banho, eu viajo de barco, eu pesco, eu ando de canoa e somente isso. São originados pelo acúmulo de água nas áreas mais baixas do tempo. Esse acúmulo pode ser devido ao derretimento de geleiras, a chegada de águas subterrâneas à superfície ou a deposição das águas de um rio. Eu boto malhadeira para pegar o peixe, preservo o lago. São porções de terras emersas, cercadas pelas águas de um oceano, mar, rio ou lago. Elas são também pequenas ou grande dimensões. São formadas por terras caída a partir dos vulcões que emergem do fundo do oceano". ( $9^{\circ}$ ano - escola da água).

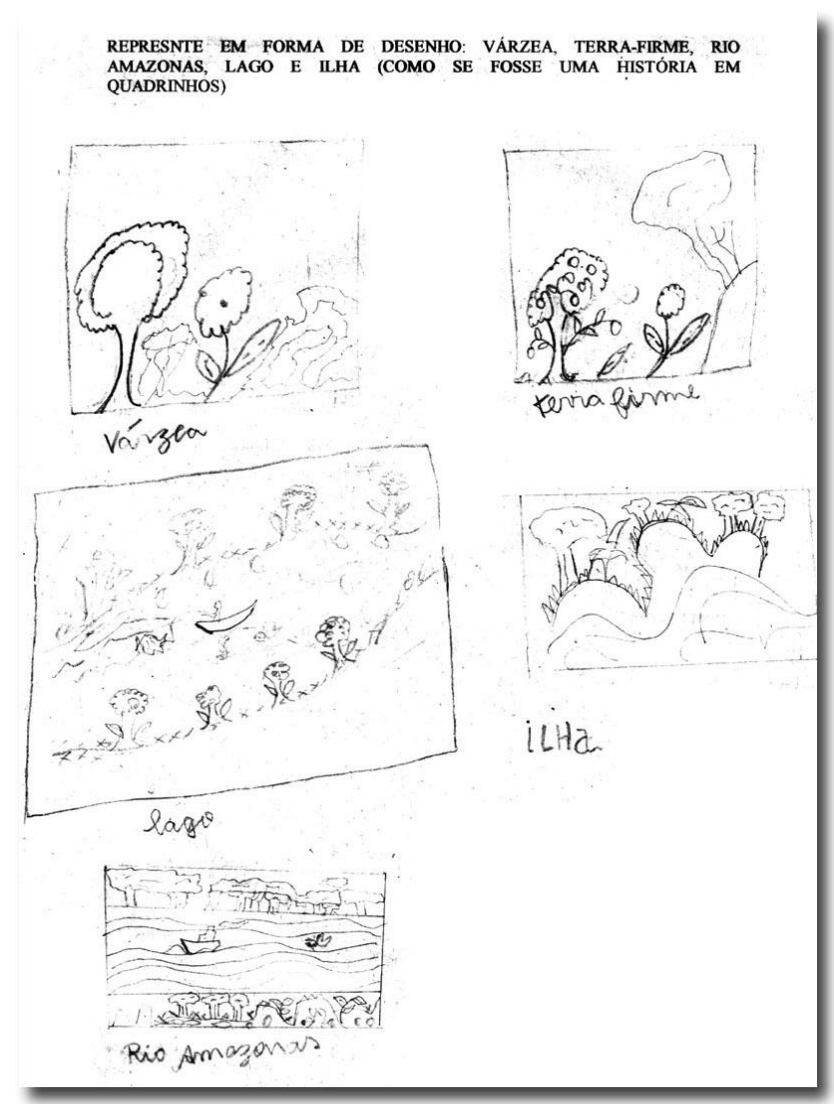

Figura 55 - aluno da escola da água 
Cada resposta dos alunos da escola da água está bem estruturada, porém, nota-se que não é uma resposta de compreensão pessoal. As respostas devem ter sido copiadas de algum livro. Mesmo assim, para transcrever tem que realizar uma boa leitura para poder escrever a resposta. O interessante que existe, no meio de cada resposta, informação pessoal do que os estudantes fazem nos lagos e nos rios. Demonstram a compreensão que possuem sobre o fenômeno das terras-caídas, das várzeas e na visão deles, não há a ocorrência na terra firme.

Fazem outras leituras sobre lago e a existência dos animais tanto na várzea quanto na terra firme. No pouco que experimentaram responder espontaneamente, mostraram o quanto conhecem sobre várzea, lagos, rios, de forma empírica. São conhecimentos construídos a partir das práticas realizadas na convivência com seus pais, nas pescarias.

"A várzea para mim é onde tem rio que é chamada de água, que tem casa, árvore. Casa, árvore, água, peixe, animais. A terra firme é onde não tem água, é seca, não é enchente, tem árvore e casas. Casa, árvore, animais. Que várzea é enchente e terra firme é seca. É onde tem peixes. Tomo banho, pesca, passeia de barco, casco, canoa, balsa. É onde tem peixes diferentes. Toma banho, pesca, passeia de canoa, barco, canoa. É coberta de terra. A ilha é tufada para cima e transforma a ilha". ( $6^{\circ}$ ano - escola da terra e floresta)

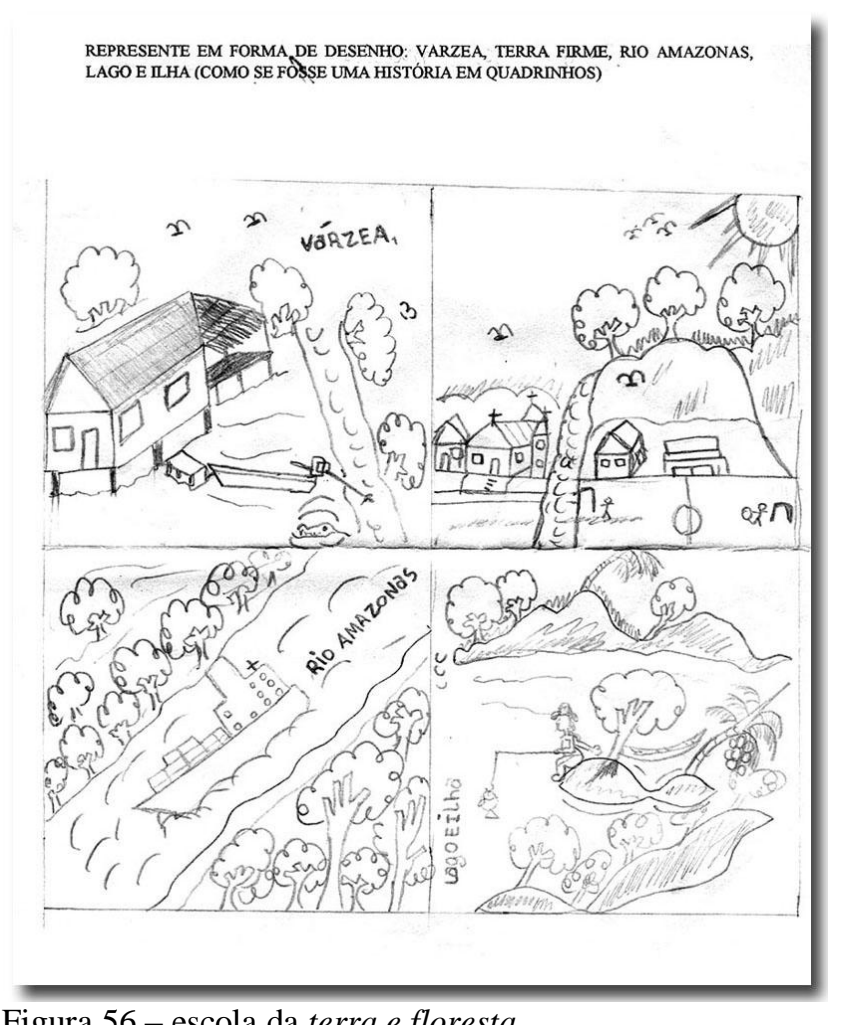

Figura 56 - escola da terra e floresta 
"Não sei. Plantações. A terra firme na nossa comunidade. Não sei. Não sei. Rio é grande e onde eu tomo banho. Tomo banho. Não sei. Eu pesco. E a ilha é muito pequena. Não sei”. (7º ano - escola da terra e floresta).

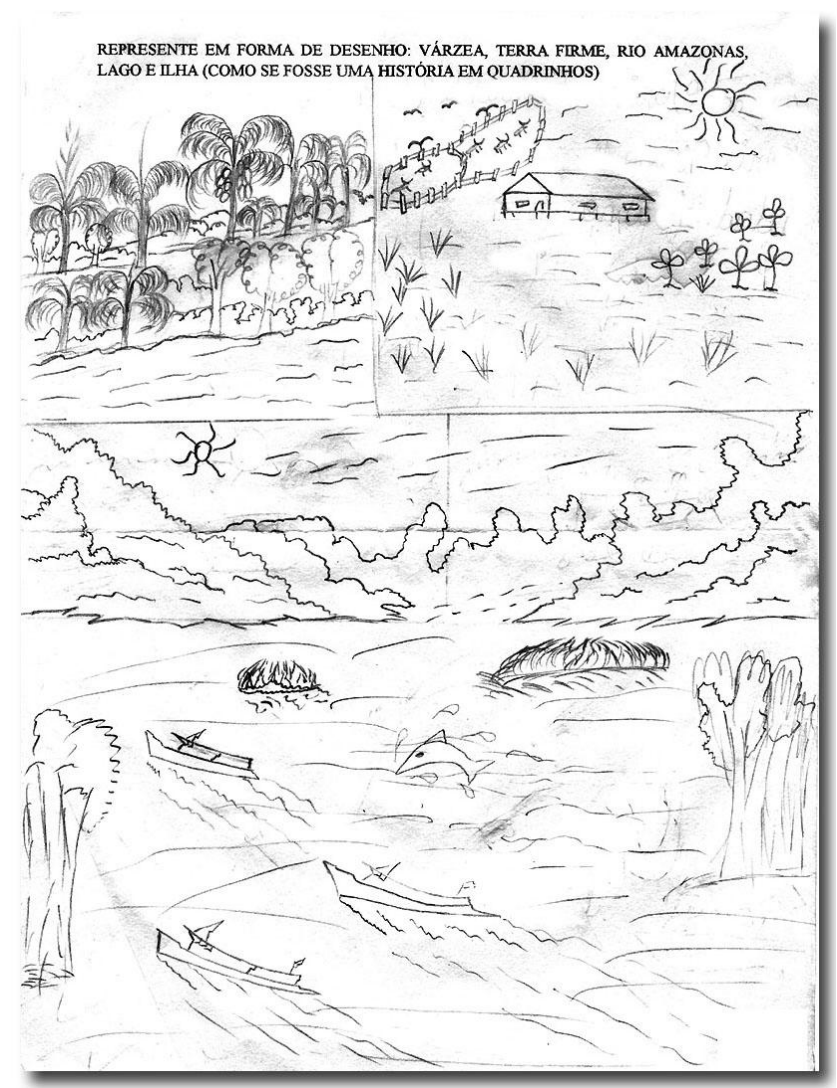

Figura 57 - escola da terra e floresta 
"É lugar calmo, onde existe plantas e animais. Para mim várzea é isso. Gado, cavalo, búfalo e plantas, etc. Carros, motos, pessoas, mas terra firme é mais agitada. É que terra firme tem mais recursos do que a várzea. É um lugar onde as pessoas passeiam e se divertem nadando. Eu preservo, eu pulo n'água, eu ajudo as pessoas a pescarem. É um rio parado onde não tem tubarão. Para algumas pessoas o lago é muito legal porque podem pescar. Eu admiro as pessoas a trabalharem para sustentar sua família. É onde existe plantas, animais e frutas. Elas é um deserto, onde a natureza é pura. Ela se forma no meio de um rio onde se obtém água em torno dela". ( $8^{\circ}$ ano - escola da terra e floresta).

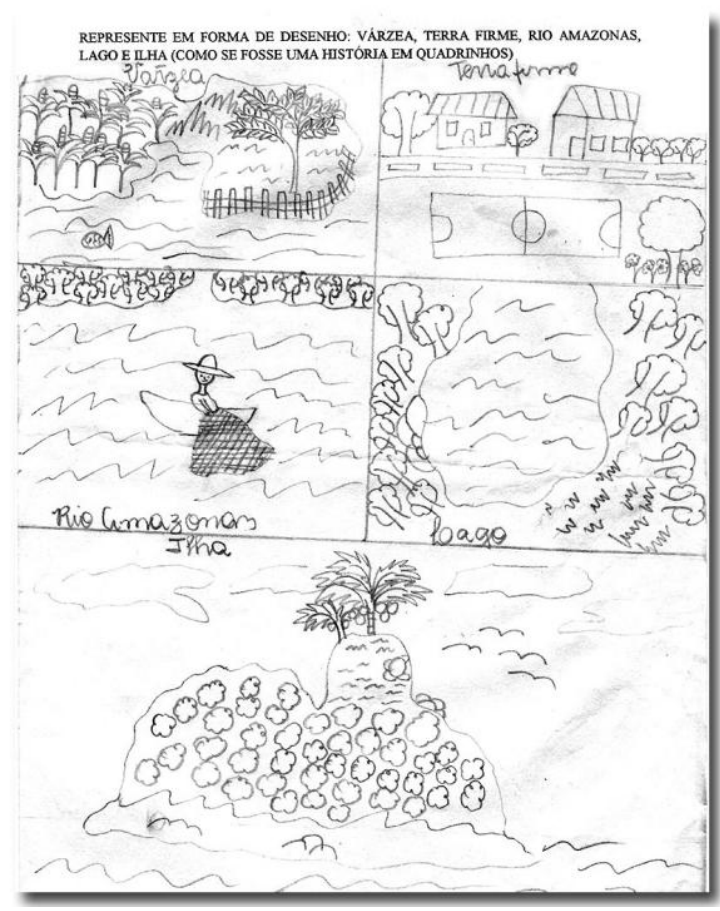

Figura 58 - escola da terra e floresta

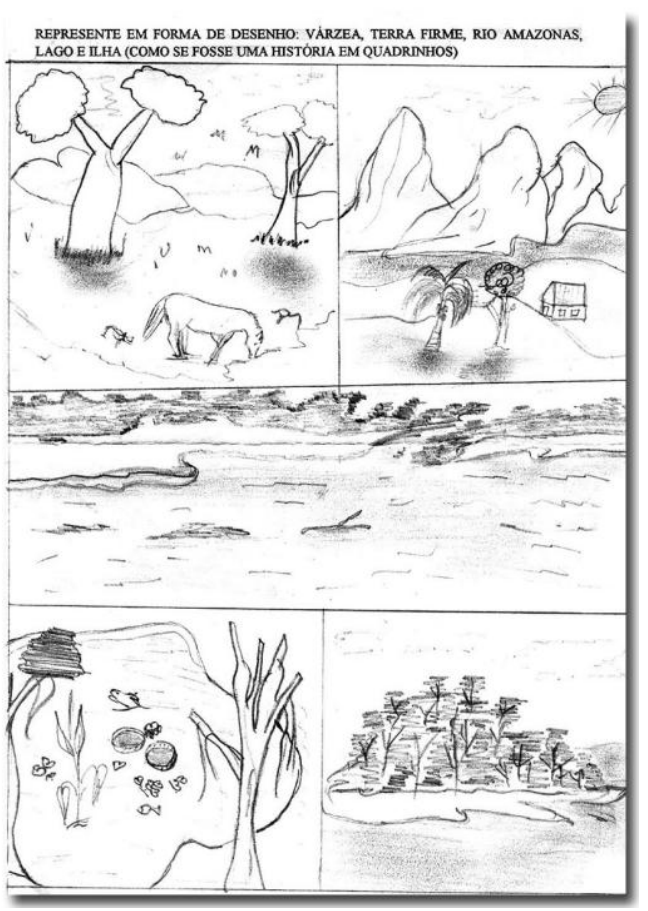

Figura 59 - escola da terra e floresta

Os alunos da escola da terra e floresta, na sua sincera resposta, demonstram que, apesar de viverem na terra firme, não conseguem expressar com palavras o que representa o que entendem sobre aspectos regionais existentes em suas comunidades.

As respostas são reflexões das concepções da geografia diariamente exercitadas e aprendidas a partir do sentido de observação, capaz de conduzir a compreensão da realidade física existente na comunidade e nas proximidades, como também entender os fenômenos naturais. 
De acordo com os desenhos, não é percebida a relação com os conteúdos ensinados na escola, a não ser as respostas dadas pelos estudantes da escola da água. As respostas são sempre a partir da vivência, não mantendo uma harmonia dos ensinamentos formais com a aprendizagem nos espaços não-formais.

Assim, os estudantes podem passar a consolidar sua base de conhecimentos porque darão sentido e significado a tudo que aprendem. Na incansável luta de construção de saberes, as respostas ao ensino de geografia e à aprendizagem estão nas representações ou projeções das respostas em forma de desenhos. O sentido é sempre perceber o quanto de Geografia é praticada pelos estudantes.

Diferentemente das respostas, os desenham expressam o conhecimento que os estudantes possuem sobre cada elemento das questões formuladas. Esta trajetória marca a relação que o aluno possui com o lugar de estudo e de moradia, onde se constrói como eterno aprendiz.

\subsection{Aprendendo com o saber tradicional nas comunidades ribeirinhas de Parintins}

As comunidades ribeirinhas da Amazônia são cheias de representações, tais como: a casa construída sobre assoalho, o templo religioso, a sede de reuniões e as reuniões, as plantações e o trabalho, a distribuição das residências, a floresta e inúmeros animais, a erosão fluvial e o próprio rio - que permite navegar para lugares próximos e distantes, através de cascos, canoas ou de barcos regionais, transportadores de vidas e esperanças de um lugar para outra, entre uma paisagem natural ou paisagem cultural, dentro da mesma região.

Estas representações compõem os matizes amazônicos, principalmente as comunidades que, ao serem vislumbradas na distância, parecem manchas brancas em contraste com o verde da floresta e o amarelo da água barrenta do rio Amazonas. Apresentamse em sua forma e em sua organização sócio espacial, quando se aproxima.

São lugares pequenos, simples e humildes, mas grandes na sua forma de ser. Comunidade é ter, no meio, a escola que ensina e aprende nos múltiplos momentos de convivências dos saberes sistematizados da Geografia (currículo) e dos saberes tradicionais, todos responsáveis pelos ensinamentos aprendidos por estudantes ribeirinhos. Por serem e estarem relacionados, existem e estão conjunta e paralelamente na comunidade. Por que estes saberes não se comunicam diretamente? Eles se negam ou eles só convivem na comunidade? 
O que falta para se tornarem um único saber, tornando o currículo de Geografia mais significativo e a aprendizagem com um outro sentido de aprender? As respostas aos questionamentos se faz presente na ausência de diálogo entre os dois saberes - saber escolar e saber tradicional. O segundo não é negado, mas não é utilizado como processo de aprendizagem na sala de aula.

Os ribeirinhos da várzea possuem um contato direto com a água, projetando seu imaginário sobre o que não compreendem e encontram, na crendice ou nos mitos, respostas às dúvidas sobre determinado fenômeno natural. Os da terra firme são envolvidos pela floresta e passam a criar seres protetores de todos os recursos florestais. Tanto um quanto outro acredita na existência dos encantados e nas entidades que protegem o vale amazônico, impondo medo aos amazônidas e respeito ao que chegam.

\begin{abstract}
Assim, o amazônida procura conviver, viver e fazer viver o mito, como energia que alimenta a alma e fortalece o conhecimento do caboclo ou do índio. Estes procuram agir com respeito sobre a floresta que o protege e o alimenta. É na floresta que percebe o quanto precisa respeitá-la para poder conhecê-la, porque dentro dela há os protetores como o curupira, o mapinguari, o juma, o jurupari e muitos outros seres que vivem protegendo-a das mazelas e interesses dos homens. Além da floresta há também a água que guarda segredos indecifráveis como a cidade encantada que fica embaixo d'água, onde os botos são soldados e que vivem de forma diferente dos humanos. (SOUZA, JOSÉ CAMILO 2005, p. 74).
\end{abstract}

Os ensinamentos dos pais aos filhos ocorrem nas rodas de conversa no final de tarde. Os jovens ou as crianças apenas ouvem e assimilam o que está sendo falado e depois lhes é dito para que tenham atenção e cuidado com os encantados, quando forem à beira (margem) do rio pegar água ou tomar banho, porque na água há vidas diferentes, que não é só de peixe. Há bichos (animais) desconhecidos. O encantado seduz as pessoas e as leva para sua moradia fazendo desaparecer do convívio social terreno para viver no mundo dos encantados e volta apenas nos sonhos de seus pais. Assim, o medo e o respeito formam conjunto de cuidado e aprendizagem.

Os relatos são repletos de significados geográficos por envolver o lugar e todos os aspectos sociais, culturais, ambientais. Torna-se elemento essencial para a estruturação da aprendizagem significativa. O relato de uma roda de conversa na casa dos moradores da comunidade onde se encontra a escola Tiradentes, Itaboraí do Meio, ilustra e enriquece o imaginário de quem alimenta e exercita a mente, fazendo projeção de imagem do fato ocorrido e relatado. 
É importante frisar que o diálogo, na roda de conversa, foi mantido na íntegra para que se possa perceber a riqueza de informações, dos detalhes dos acontecimentos e da forma como os pais ensinam seus filhos.

Em 2010, o administrador da Área de Proteção Ambiental Nhamundá, mas conhecida como complexo de lagos do Macuricanã, inicia o diálogo falando de um projeto de diversas plantações que se pretende implantar na comunidade. A conversa fluía livremente com muitos risos. Após troca de várias informações, foi direcionado o diálogo com uma simples pergunta:

A: vocês moram aqui desde quando?

$B^{18}: 37$ anos morando.

A: 37 anos... Vocês vieram da onde?

C: ele veio lá da cidade. Nós somos daqui mesmo do Itaboraí.

D: foi ela que arranjou ele.

B: nós casemos lá e depois nós viemos embora para cá.

C: os pais dele moram lá na Senador Álvaro Maia, naquele que vai da Cordovil para sair prá lá.

A: aqui vocês produzem o que, além de criar gado ou não criam gado?

C: esse gado aqui é do meu filho; para não dizer que não temos, temos uma vaca.

E: plantam feijão, melancia...

C: não temos mais plantado essas coisas devido a esse negócio de criação.

A: vocês trabalharam com a juta?

$B$ : trabalhamos com a juta logo que chegamos aqui.

A: vocês pescam?

B: pesca agora não pesco, mas já pesquei muito.

A: seus filhos pescam?

B: este pesca.

A: a malhadeira quem é que faz?

B e C: ele mesmo que faz... Ele mora aqui perto de casa, mas ele mesmo faz.

A: Quem ensinou ele a fazer a malhadeira.

$C$ : ele aprendeu com os outros que sabem

E: o senhor pescava de que... de arpão?

B: de arpão, de zagaia de caniço, caniço, espinhel, tarrafa; até hoje ainda tenho...

D: a pescaria com a malhadeira... O peixe cai na malhadeira se ele quiser. (risos). Porque eu estava no galho do pau, tava assistindo a coisa do peixe, tava olhando a malhadeira que tinha colocado para pegar a broca (comida), um igarapezinho estreito; eu disse quero ver o jeito desse peixe como ele vai cair nessa malhadeira; ele subia até uma certa parte na malhadeira e ai ele baixava; ai mergulhou pelo fundo e passou por baixo. Ele cai na malhadeira se ele quiser. (risos).

A: como o senhor identifica no lago que lá tem peixe?

D: porque a gente fica manjando o movimento do peixe, ai a gente vê eles.

A: como o senhor sabe, quando vai colocar a malhadeira, que ali vai passar peixe?

\footnotetext{
${ }^{18} \mathrm{O}$ nome dos moradores e todos os participantes deste processo de roda de diálogos serão denominados por letras $\mathrm{A}, \mathrm{B}, \mathrm{C}$ e assim sucessivamente. O sentido é guardar o anonimato, mas manter a forma da fala do informante para expressar a riqueza do que foi falado, como foi falado, mostrando a geografia existente em cada fato ou acontecimento exposto. Assim, estará sendo protegido o direito ao anonimato da pessoa. Além dos que se expressaram, havia outras pessoas que permaneceram caladas somente ouvindo, assim como as crianças que sorriam com o ritmo da conversa.
} 
D: porque fica pitiú a água. O caboco chega lá mete a mão na água e cheira e se tá pitiú ele joga o arreio porque ele sabe que tem peixe

A: então o peixe se denuncia para o senhor.

D: ele se mostra (risos de todos os presentes)

A: qual é o melhor horário para pescar?

D: eu prefiro fazer um trabalho do que estar na proa de uma canoa, porque não é lucro para mim. Não é lucro porque o cara passa o dia inteiro sentado; antes pegar no cabo do terçado e estar sabendo que vai produzir.

A: assim, quando o senhor vai colocar a malhadeira para pegar a broca, só para comer. Qual o melhor horário para pescar?

$D: E$ de manhã, porque a partir das 9 h o peixe vai embora pro barranco, pronto. Ai ele não vem mais porque o sol tá quente. Esquentou a água que clareia e ele vê tudo.

A: quando o senhor vai para o lago. Como acerta ir e voltar? Uma vez fomos aqui no lado do Macuricanã, a gente se perde. Como o senhor se orienta? (risos pela C)

D: uma comparação: aqui eu não estou sabendo da estrada, mas ai o cara já vai fazer a estrada dele mesmo; ele faz no local - pela mesma que ele vai ele vai ter que voltar; se ele vê se prá cá dá para ele ir, ele vai mais na frente; aí ele não vem mais por aqui e ele já quer atalhar; já vem sair aonde ele foi.

A: lá no lago está cheio, aconteceu conosco, no outro lado não se está vendo nem árvore, porque os lagos são muito grandes. Como se guia ai?

D: mas olhe, quando o rio é grande igual esse aqui, se você prestou atenção, prá cá é uma ilha prá lá é outra, você não vai se guiar pela ilha que você está olhando, vai voltar se guiando pela ilha que você veio. Senão você vai perder o equilíbrio; se perdeu vai ficar muito longe.

E: aí, por exemplo, o senhor se guia por uma árvore?

D: pela árvore e mesmo pela coisa da corrente, da correnteza; se ele for só pela coisa da árvore ele não volta.

A: se o senhor entrar num igapó, por exemplo, como o senhor sai de lá.

D: se for escuro... Tira o rumo (risos do $C$ ).

A: como tira o rumo?

D: se for uma comparação, prá cá, eu vim prá cá e eu vou sair aqui e ai eu tiro para sair fora.

E: esse rumo o senhor se baseia em que? Por exemplo: eu me oriento assim, o rumo é prá cá mais tem aquela árvore lá que eu não posso me esquecer, porque eu tenho que ir direito naquela árvore, porque também num descuido a canoa roda, e aí?

D: aí, também, você já coisa, se guia, pela coisa do vento, também.

$E$ : aí tem que ver o vento.

D: se tiver ventando daqui eu vou prá cá. Você vai a favor do vento. Se for contra o vento, mano, já era. Nem que ser aqui prá traz; aqui é um igapozão; não tem estrada, não tem nada; você diz, ainda vou em tal paragem e ai você vai embora, até onde der para ir e voltar, porque se anoitecer prá lá você não volta, porque é muito escuro.

C: mas, se ele souber por onde ele foi, né...

D: é, ele pode até voltar, mas de noite, assim no escuro é meio difícil e se voltar tem a cobra, né, ainda mais descalço.

A: tem pessoas que vão pegar pitiú (quelônio) e vão no escuro, como ele sabe ir e voltar.

D: porque ele vai na praia.(risos do $C$ )

A: tem uns que pegam no barranco; fazem aquela queimada. 
D: porque ele vai aberando o lago. Não tem que sair para terra. Todo tempo vai na canoa.

A: me diga uma coisa: e a visagem? (risos do $C$ e A)

D: não sei se tem visagem.

A: e o boto?

D: o boto se ele se engera, mas o homem também. (risos de todos)

E: me disseram que tinha o calça molhada.

D: porque olha, sabe o que faz o medo? É a pessoa mesma

E: Quem faz a visagem é a pessoa.

D: Ele mesmo faz a visagem. Porque vai dizer faz visagem em tal parte, mas não tem. Eu ainda não vi nada.

C: um tempo, logo que chegamos para cá tinha um negócio...

$F$ : carregando um pirarucu molhado lá do lago rapo rapo rapo (riso de todos)

E: tem uma história aqui, não sei qual a comunidade, de uma mulher que foi menstruada para o lago ai ficou gestante e quando nasceu, nasceu um bicho igual сиіисиiu.

C: o puraqué...

$F$ : o caboco era feio mesmo. (riso de todos).

A: como aconteceu?

E: não esse negócio das mulheres quando estão menstruadas não pode ir para a beira do lago, ai ela foi desobedecer essa regra e foi pescar e quando ela veio de lá ela ficou gestante e quando nasceu era uma gente, mas a cabeça era de cuiucuiu. (silêncio).

F: ela desejou muito a cabeça de cuiucuiu. (risos de todos).

A: e na enchente como vocês passam aqui?

B e C: nós passamos na terra firme. Nós temos uma terra firme. Vivemos com a água até um metro.

$C$ : quando não menos. Antes a gente ficava por aqui mesmo, não tinha perigo.

A: na cheia, onde vocês pescam? Aonde arrumam comida?

B: a gente pesca por aqui mesmo e lá na terra firme a gente dá um jeito de pescar.

A: e a cobra-grande? A sucuriju não aparece?

$B$ e C: já faz um certo tempo que não tem aparecido, mas que tem, tem. Inclusive jacaré deve ter por esses lagos. Agora jacaré dá medo da gente andar; daqui de casa a gente escuta o urro do bicho; e eu digo mesmo Deus do Céu.

B: já pesquei muito nesse mundo, quando eu era bom. Saía aqui de casa e ia embora e anoitecia muito longe e chegava prá cá duas ou três horas da madrugada. Nunca vi nenhuma marmota de visagem. Meu corpo é fechado, graças a Deus.

E: papai disse que tinha uma tapiraiauara.

$B$ : tapiraiauara tem; só vi o movimento dela.

A: como é que é a tapiraiauara? O senhor já viu?

B: tipo uma rês, assim. Estranha. Ela não se mostra prá gente vê. Já ouvi falar que o pé e mão é de capivara. O corpo é de animal mesmo e tem a cara de cavalo; a cor dela é preta. Ela urra, bate n'água, assim: teipei teipei teipei.

D: ela protege mais o aningal. Ela gosta mais do aningal; do barranco, porque é a casa dela. Ela vai em terra, mas é de repente, mais é n'água.

A: você já ouviu ela?

D: eu já vi foi ela pura. Ela é preta. Só que ela é, a cara dela é de cavalo, mão de boi. Só que ela não é um bicho que prejudica e come gente, porque se ela fosse, partia para cima de nós. Agora ela joga uma catinga e o cara fica logo zambeta. Catinga é um fedor. 
A: e a cobra grande o senhor já ouviu falar? Será que é ela que derruba o barranco?

$D$ e B: ainda não vi ela não. Acho que é ela sim. O cara não deve abusar muito, porque no fundo que ela fica. Só vê ela se ela boiar; ela não o fogo dela; o olho dela.

A: como o senhor ensina o seu filho conhecer o lago e a pescar?

$D$ e B: quando eles estão pequenos eles já vão na popa para irem aprendendo, porque se um dia o velho faltar ele já tomam a frente.

A: desde que idade o senhor levou eles para pescar?

D: os meus, quando começaram já estavam com dez anos, porque se criaram mais na cidade; prá viaja só vieram depois de tarem já home já.

Estes diálogos na roda de conversa, expõem o lugar de pescaria e quem é o guardião do lago. Fala do tipo de vegetação, componente importante para a alimentação dos peixes e também serve de esconderijo para a reprodução e povoamento dos lagos. O ribeirinho tem registrado em sua mente que o lago é detentor de mais peixe. E ensinam os filhos a perceberem através de folhas comidas, do cheiro dá água e de frutos. Como um grande observador, desenvolvido pela vivência, aprendeu andar "tirando o rumo", ou seja, sabe se orientar pelos lagos, matas ou rios, sempre com a certeza do retorno. $\mathrm{O}$ aspecto sociocultural se faz presente, assim como a crendice e os mitos se projetam em suas falas, permitindo a construção das imagens na mente, um verdadeiro exercício mental.

Vários outros relatos foram feitos, seguindo a mesma linha desta roda de conversa. Em um momento ímpar, convidado a participar de um circuito de observação nos lagos do complexo Macuricanã, em um determinado momento, o pescador parou a canoa junto ao bloco grande de capim e falou que iria contar pirarucu.

Foi observado o exercício mental, verdadeira engenharia matemática na contagem, onde chegou a determinar o tamanho e projetar o peso aproximado de cada peixe. Sempre chamando a atenção do filho para prestar atenção. Depois disse que o pirarucu vem à superfície respirar sempre no mesmo lugar. Naquele lugar se encontravam vinte pirarucus, entre pequenos e grandes. Não se fez o relato detalhado da contagem do pirarucu para preservar este saber local, mas representa uma importante base de saber, que poderia auxiliar no ensino de geografia na escola. O conjunto de informação existente na roda de conversa poderá ser transposto ao conhecimento escolar, associado aos conceitos geográficos, valorizando o dialeto local, por ser o elo revelador da identidade cultural: manjando (observando), pitiú (se refere ao cheiro do peixe), aberando (seguindo pela margem) e engera (transforma). Há muitas outras expressões que determinam o lugar de vida de quem o constrói diariamente. 
Os filhos aprendem com seus pais na prática diária do fazer, porque é a luta pela sobrevivência e pelo viver a liberdade existente dentro de cada ribeirinho, seja de terra firme ou várzea, mas o sentido é o mesmo, saber lidar com a água e com a floresta, conhecendo suas limitações pessoais, com respeito, podendo ir até onde for possível ou permitido, como foi dito na entrevista, "senão não volta". Seguir os ensinamentos dos mais velhos é aprender a conhecer cada ambiente natural e saber retirar ou explorar com racionalidade os recursos naturais para manter atualmente o que existe e conservando para as gerações futuras.

A vivência nas margens do Amazonas requer um ensinar e aprender contínuo para enfrentar as diversas situações exigidas para sobrevivência local. Na figura 60 é possível ver a habilidade da mulher em atracar e desatracar do barco-empurrador de balsa, que transporta carreta e outros produtos do sudeste para Manaus, sem que este reduza a sua marcha de viagem, ou seja, a velocidade em que está viajando. Esta movimentação só foi percebida nesta comunidade, apesar de ter visitado todas as comunidades da margem do rio Amazonas dentro do município de Parintins, até a cidade de Manaus. Há registro de prática de comercialização de açaí no Estreito de Breve, no estado do Pará. Os moradores de Vila Amazônia, comercializam toda sua produção em Parintins.

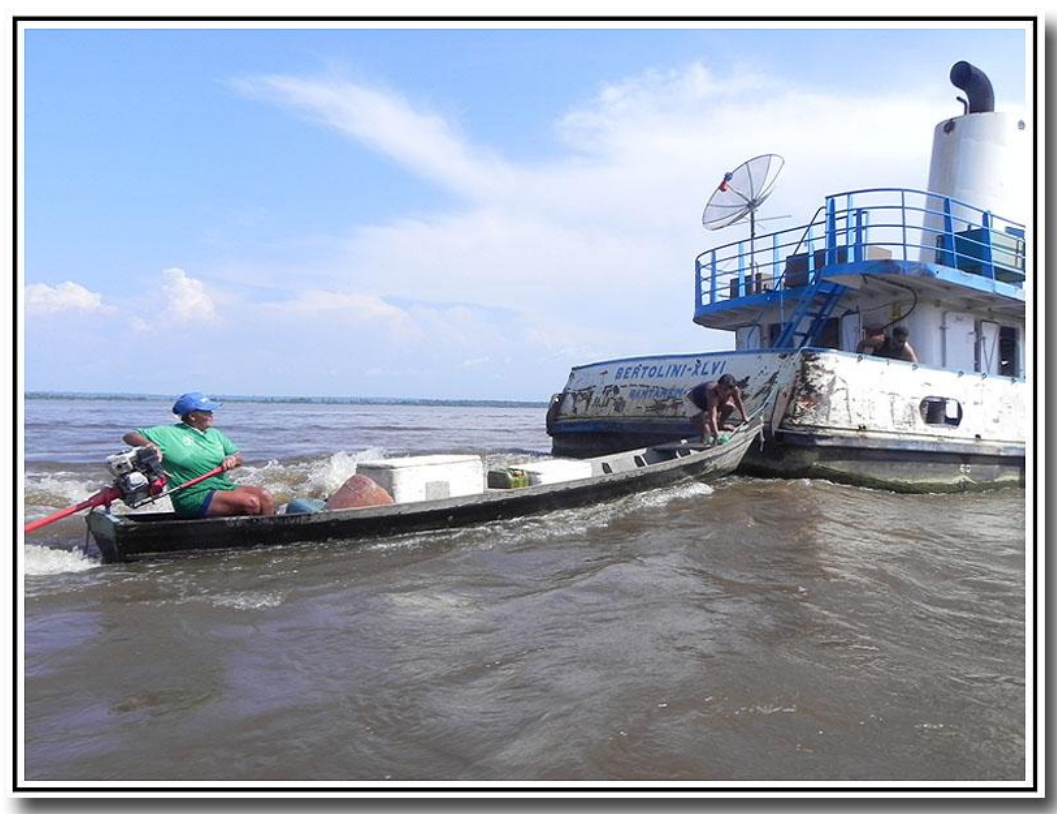

Figura 60 - mulheres do Itaboraí comercializando produtos agrícolas e peixe. Foto: Camilo Ramos/ outubro/2011 
Esta prática na comunidade do Itaboraí do Meio acontece somente com algumas famílias. As crianças, homem ou mulher, são responsáveis de cuidar das plantações e das criações e também de verificar a malhadeira na margem do rio Amazonas de onde extraem o seu alimento. As mulheres mais velhas e os jovens adolescentes são responsáveis por pescaria nos lagos distantes, onde tem que percorrer em média entre um a dois quilômetros de distância de ida e o mesmo percurso de volta, mas com o peso do que foi pescado. O caminho por terra, no período da enchente é feito em parte dentro da floresta de várzea, parte em áreas alagadiças e parte em vegetação rasteira do tipo gramínea. Em todo percurso há sempre o perigo de animais peçonhentos, caminham com todo cuidado para não serem acometidos por doenças, porque afeta o ritmo de suas vidas ribeirinhas.

Devido à distância para a cidade de Parintins, segundo a matriarca da família, passaram a comercializar a sua produção com as embarcações que navegam diariamente pelo rio Amazonas, no sentido Leste-Oeste ou Oeste-Leste. Já criaram um código de comunicação: quando querem peixe dão duas buzinadas ou quando querem outro produto buzinam apenas uma vez, para avisar. Toda comercialização se dá por dinheiro ou por escambo (troca de produto por produto). Esta prática auxilia os moradores que não precisam mais ir à cidade vender a sua produção.

No período da enchente a prática continua porque a produção agrícola de hortaliças é feita em balcão suspenso e a captura de peixe também segue o mesmo ritmo da enchente, com uma grande diferença, o deslocamento é feito de canoa, facilitando o transporte e a vida de quem vive da e na água. 


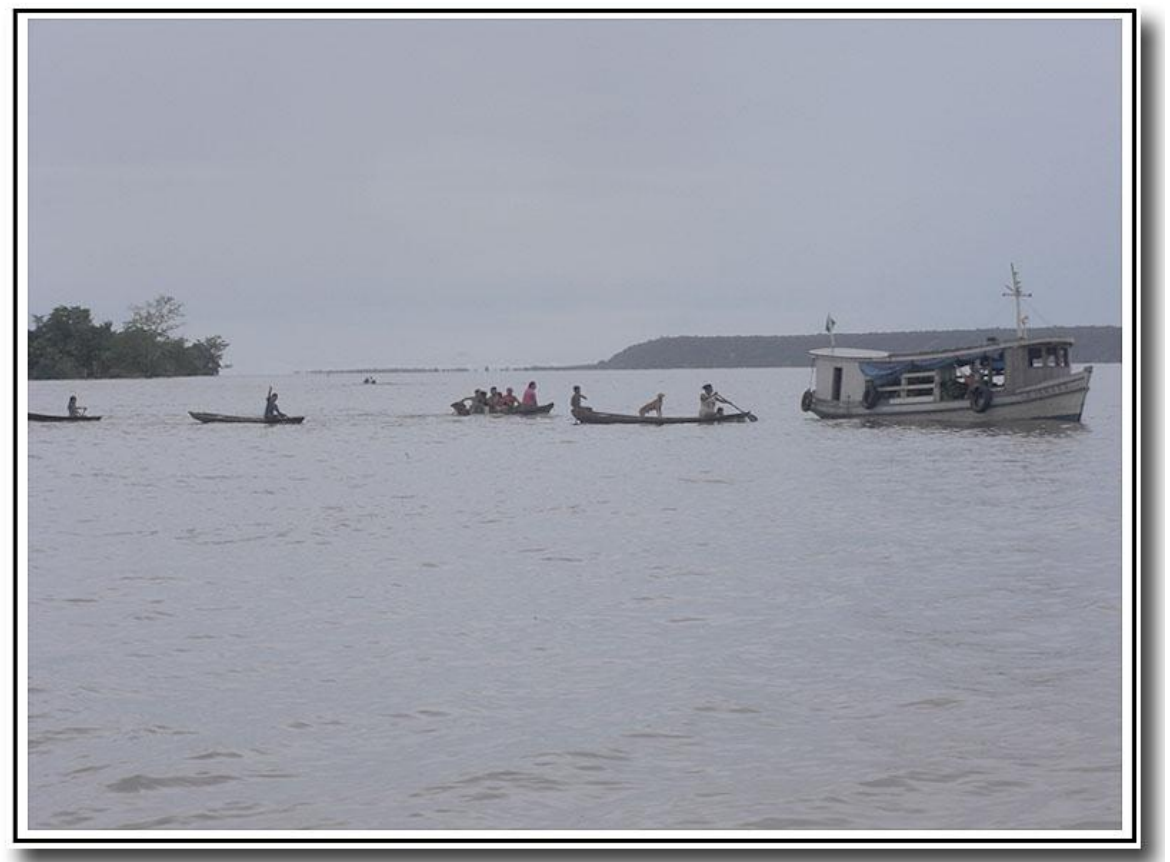

Figura 61 - moradores do Itaboraí do meio comercializando sua produção na enchente Foto: Camilo Ramos - abril/ 2010

A contribuição ao ensino de geografia está na geografia praticada, mesmo não sendo percebida ou identificada ou os conteúdos estudados na sala de aula não permitam uma leitura do que está sendo feito é Geografia Econômica, Geografia do Transporte (Meios de Transporte), Geografia Agrária, Geografia da População e de forma mais abrangente a Geografia Cultural. A escola poderia trabalhar o currículo oficial exercitado na sala de aula com o currículo praticado na comunidade pelos estudantes nas atividades domésticas e comunitárias.

A aprendizagem seria muito mais significativa, porque morar sobre a água é viver a dinâmica do próprio rio, pela falta de peixe ou pela impossibilidade do morar, mas como a vida do morador da várzea é sempre um recomeço de tudo, também é uma forma de aprender e ensinar a viver a dinâmica do rio Amazonas. Os moradores das comunidades de várzea vivem dois momentos distintos: o primeiro é no período da vazante, em que todos são empenhados em produzir para comercializar, como para guardar parte do alimento para o período da enchente. O segundo é a enchente, que faz ficar dentro de casa, saindo somente para pescar. No período da cheia, as famílias ficam indefesas, principalmente, contra os ataques de animais peçonhentos (sucuriju) e dos grandes banzeiros (ondas fortes) produzidos pelos navios (Figura 63) que arranca o assoalho da casa (Figura 62). 


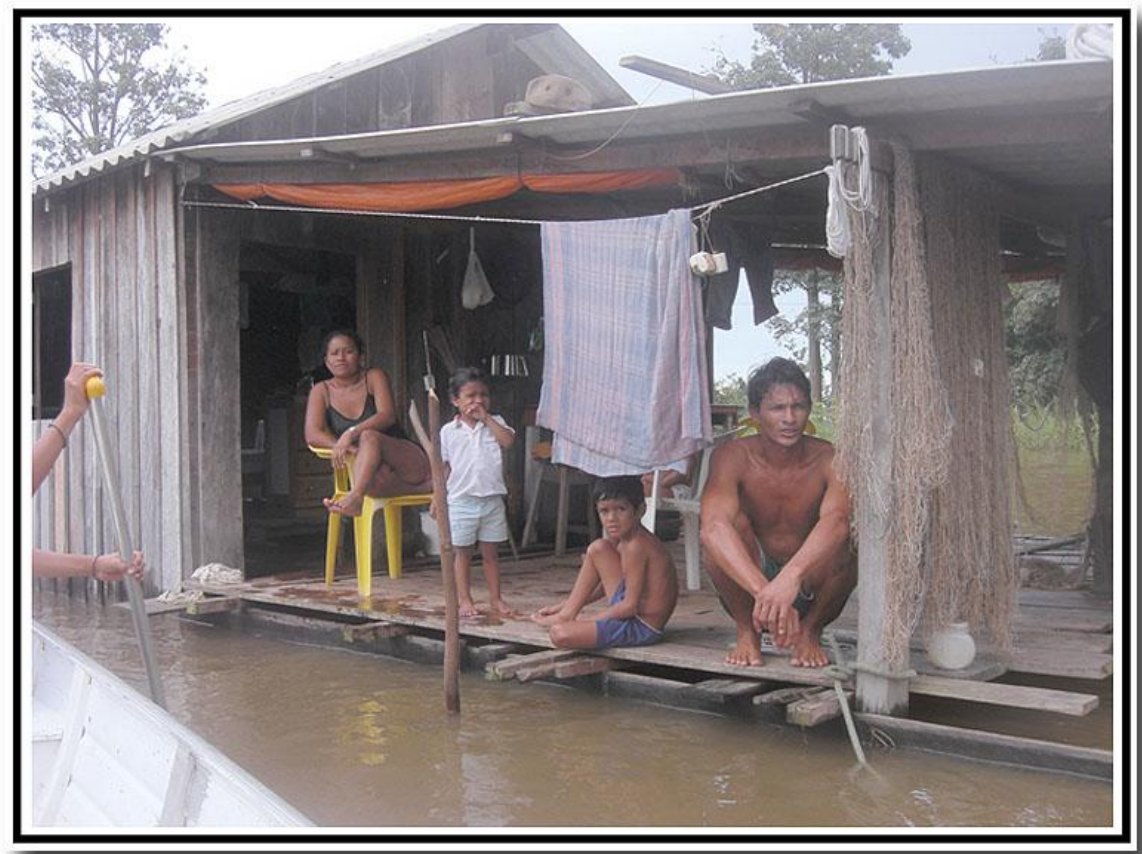

Figura 62 - Ribeirinhos no período da enchente

Foto: Camilo Ramos - abril/2009

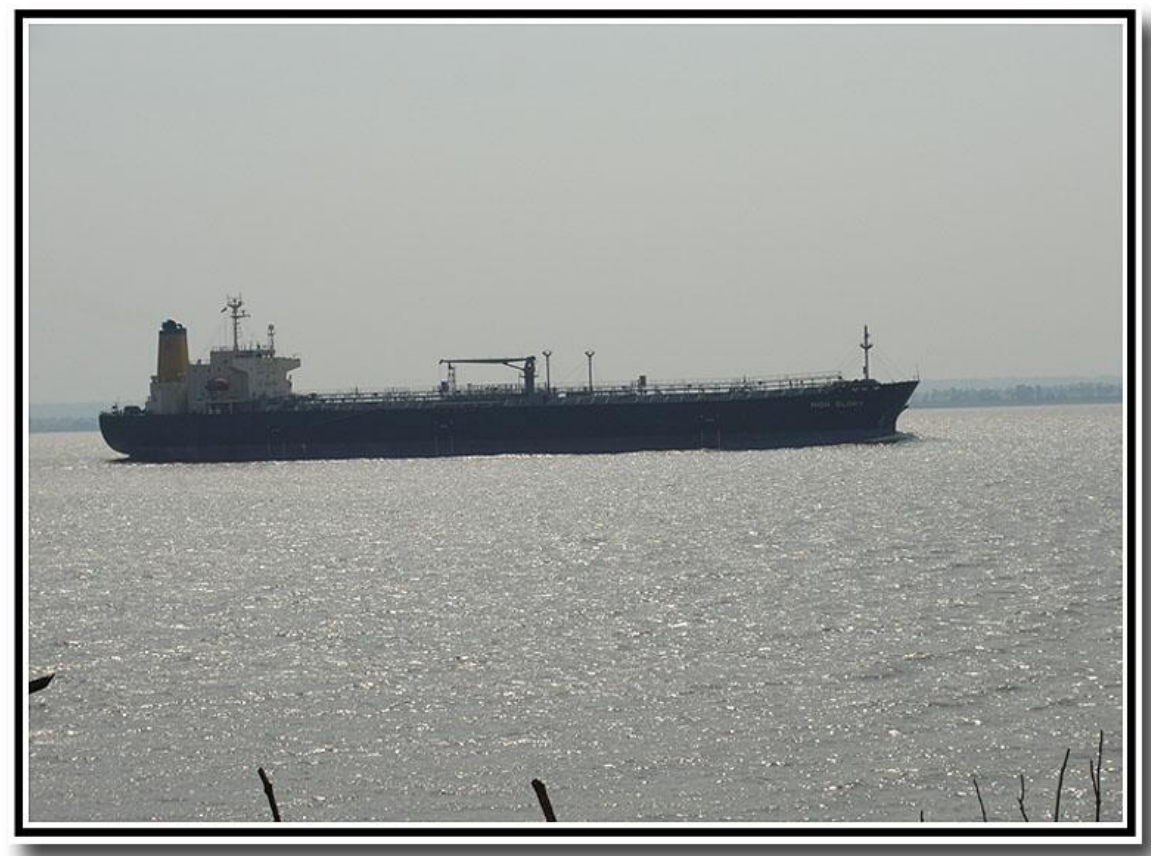

Figura 63 - Navio cargueiro - produz ondas que prejudicam o assoalho da casa do ribeirinho Foto: Camilo Ramos - abril/2009. 
Os ribeirinhos da terra firme não vivem esta dinâmica fluvial e mantém outro padrão de viver e aprender, mesmo porque estão mais voltados para a produção contínua e a utilização dos recursos naturais, como a coleta de sementes, extração de óleos vegetais, madeira e outros produtos que podem ser comercializados ou utilizados para sua própria alimentação.

Este olhar sobre a realidade ribeirinha amazônica demonstra a complexidade existente e a riqueza de informações para o ensino de Geografia no Amazonas e na Amazônia, onde o saber sistematizado e o saber tradicional são fundamentos importantes para os sujeitos aprendentes (pais, professores e alunos) estruturarem o viver em comunidade, mantendo as relações inter e intrapessoal, social e cultural no lugar de vida. Aprendendo a viver e conviver com os dinâmicos acontecimentos ou fenômenos amazônicos, a partir dos saberes tradicionais, ressignificadores do seu cotidiano.

\subsection{Possibilidades didáticas para ensinar Geografia}

Os caminhos trilhados para ver a geografia nas escolas e nas comunidades ribeirinhas do município de Parintins fizeram pensar possibilidades de abertura do espaço de representação e de construção de conhecimentos, na perspectiva de discussão do sistema amazônico percebido. Este sistema está apresentado a partir de uma folha de árvore, não como uma forma metodológica de ensinar, mas como instigador de utilização dos recursos naturais existentes em cada comunidade - para ensinar Geografia - transformando-os em recurso didático.

A representação da geografia amazônica na folha está como interação entre os meios utilizados no sentido da percepção dos novos saberes adquiridos pelos alunos no processo ensino-aprendizagem, a partir dos saber sistematizado e do saber tradicional.

Essa perspectiva de ensinar, aprender ou conhecer a geografia do lugar, fomentará temas pertinentes na realidade local como também a transformação do que é abstrato em concreto, do empírico em teórico, no sentido de facilitar a compreensão do existente em termos de conhecimento construído no currículo de geografia e também no processo de comunicação dos saberes tradicionais, demonstrados na geografia na e da folha do vegetal.

Importante destacar, neste meio instigador, o exercício mental criativo e interpretativo para ver a geografia e toda relação sistêmica entre o meio natural e toda produção do espaço socialmente organizado e explorado pelas relações antrópicas. É capaz de conduzir o 
estudante às inúmeras visões de percepção do que está próximo com o distante, compreendendo as influências inter-relacionadas dos processos globais.

A experiência com os estudantes ribeirinhos nesta atividade de ensino, dá liberdade de trabalhar com o imaginário a partir de toda fundamentação teórica, porque é investimento na ampliação do empírico para ganhar grau de importância o conhecimento da realidade vivida interligada com a nacional e global, através dos quais podem ser ressignificados cotidianamente.

Então, foi pensado, após vários momentos de observação, o que poderia se aprender com uma folha e para tanto foi construído sistema-esquema geográfico, considerando a riqueza de informações a serem trabalhadas no processo ensino e aprendizagem, na sala de aula. É importante salientar que a folha de vegetal permite realizar um ensino interdisciplinar com a Matemática, Biologia, Língua Portuguesa, Química, Física, Artes, História. Pode-se dizer ainda, que vai aguçar o poder de observação sobre os aspectos físico-naturais e sobre todas as relações de igualdade e desigualdade social. 


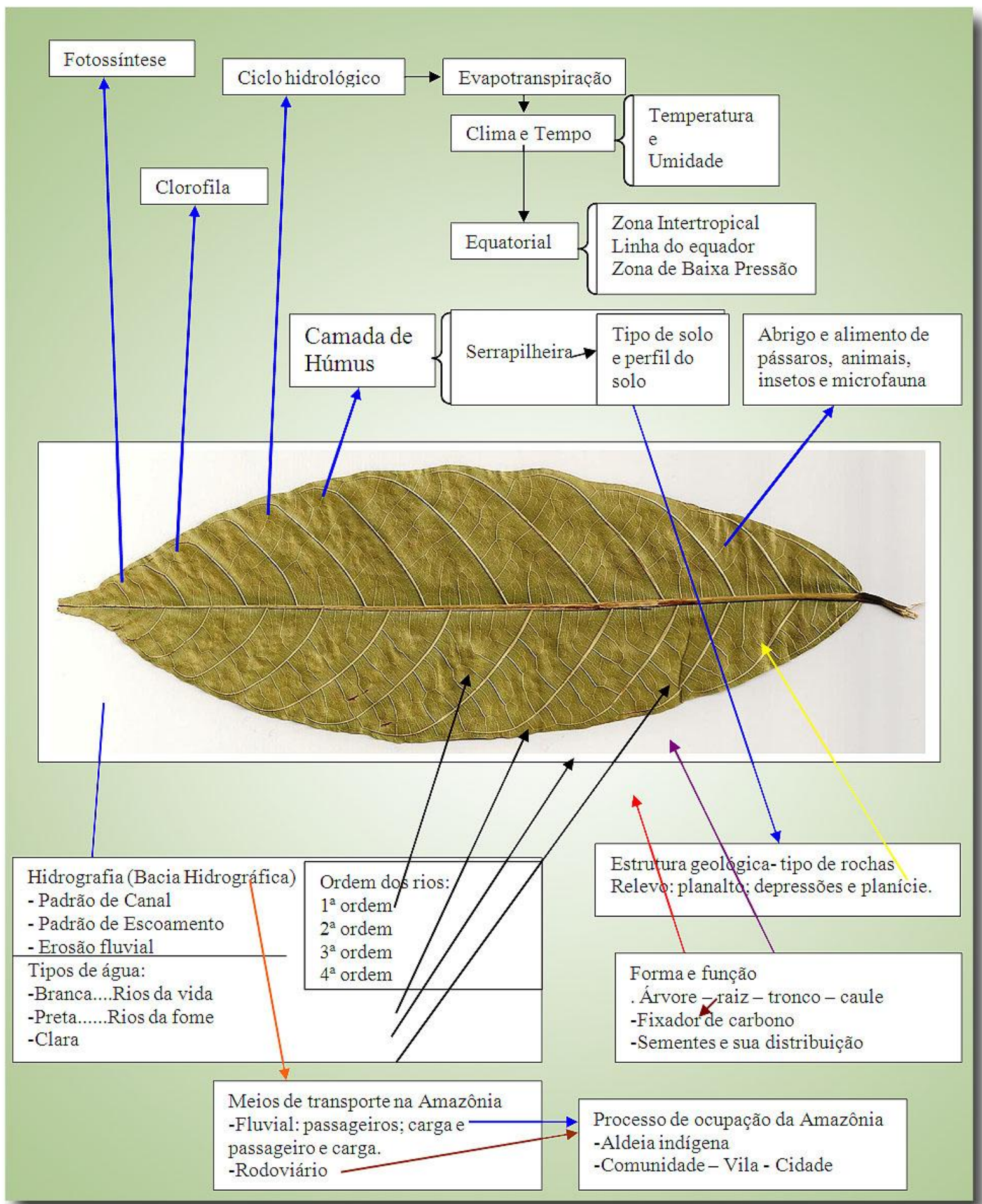

Figura 64 - representações geográficas na folha de vegetal 
No prosseguimento da exposição do sistema-esquema será feito um detalhamento das partes para, posteriormente, voltar à totalidade a ser estudada. Procurou-se trabalhar, a partir do teórico, toda relação empírica do conhecimento amazônico observado e percebido na folha para depois exercitar, em forma de aula, com os alunos das duas escolas ribeirinhas.

\section{Função da folha - Olhar Biogeográfico}

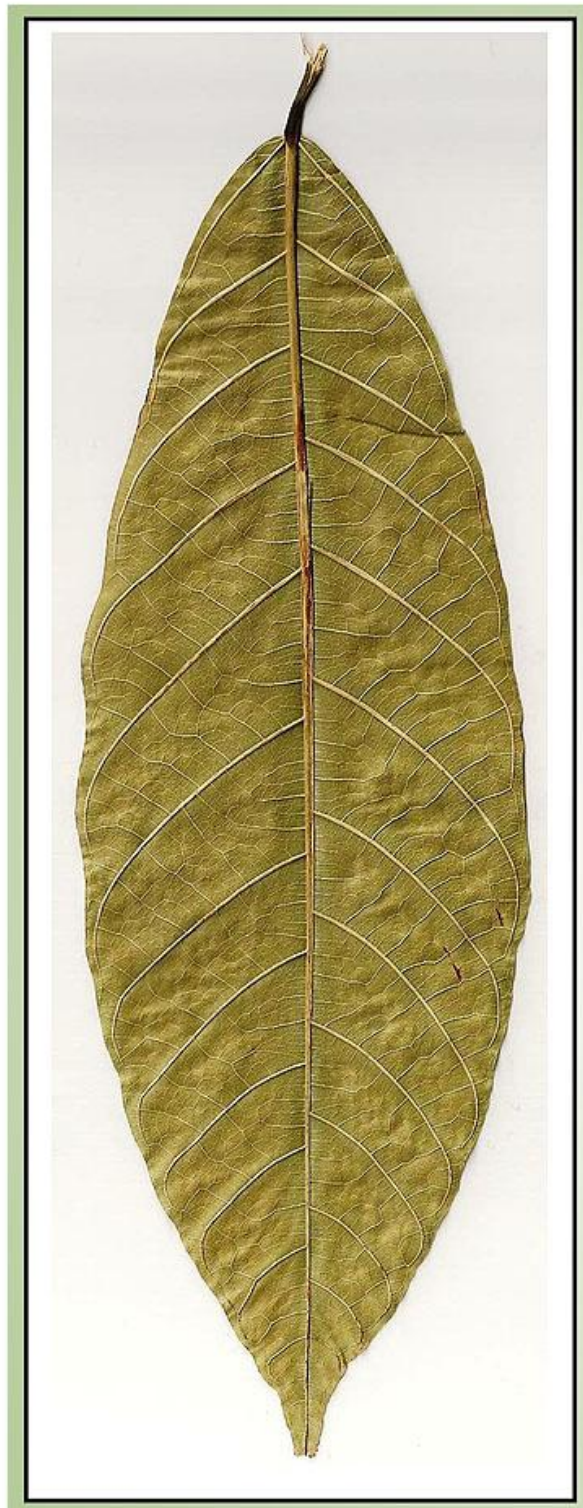

A forma achatada é favorável à exposição ao sol, por onde capta energia solar; sua cor verde advém da clorofila, a qual possibilita a realização da fotossíntese.

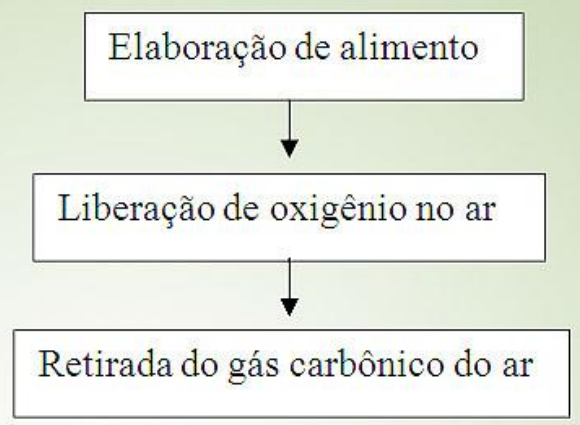

Neste processo intenso há a liberação de água pela folha (evaporitos).

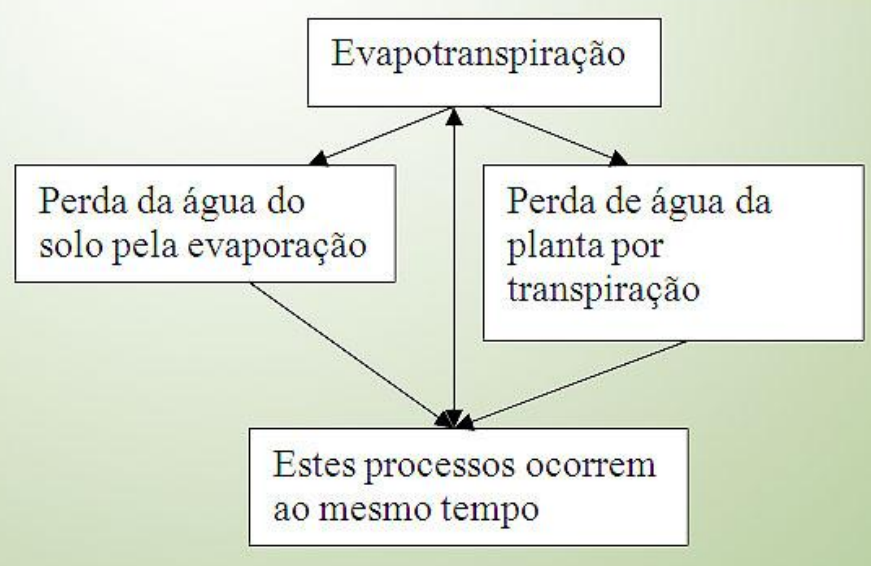

Figura 65 - Função da folha - Olhar Biogeográfico 
A água evapotranspirada vai compor a umidade do ar (quantidade de vapor d'água no ar atmosférico). Esta água no ar transforma-se em nuvens e depois de condensadas precipitam em forma de chuva. À noite, sem o calor do sol, descem molhando a superfície - lugar - outra forma de precipitação.

O olhar instigador está para ver e aprofundar o que é possível trabalhar com a folha, em termos geográficos, ou seja, o encadeamento está ligado ao processo climático, considerando a zona tropical dentro dos dois trópicos: o de câncer e o de capricórnio.

Pela proximidade da linha do equador, na Amazônia tem a predominância do clima equatorial, interligado com o tropical e subtropical.

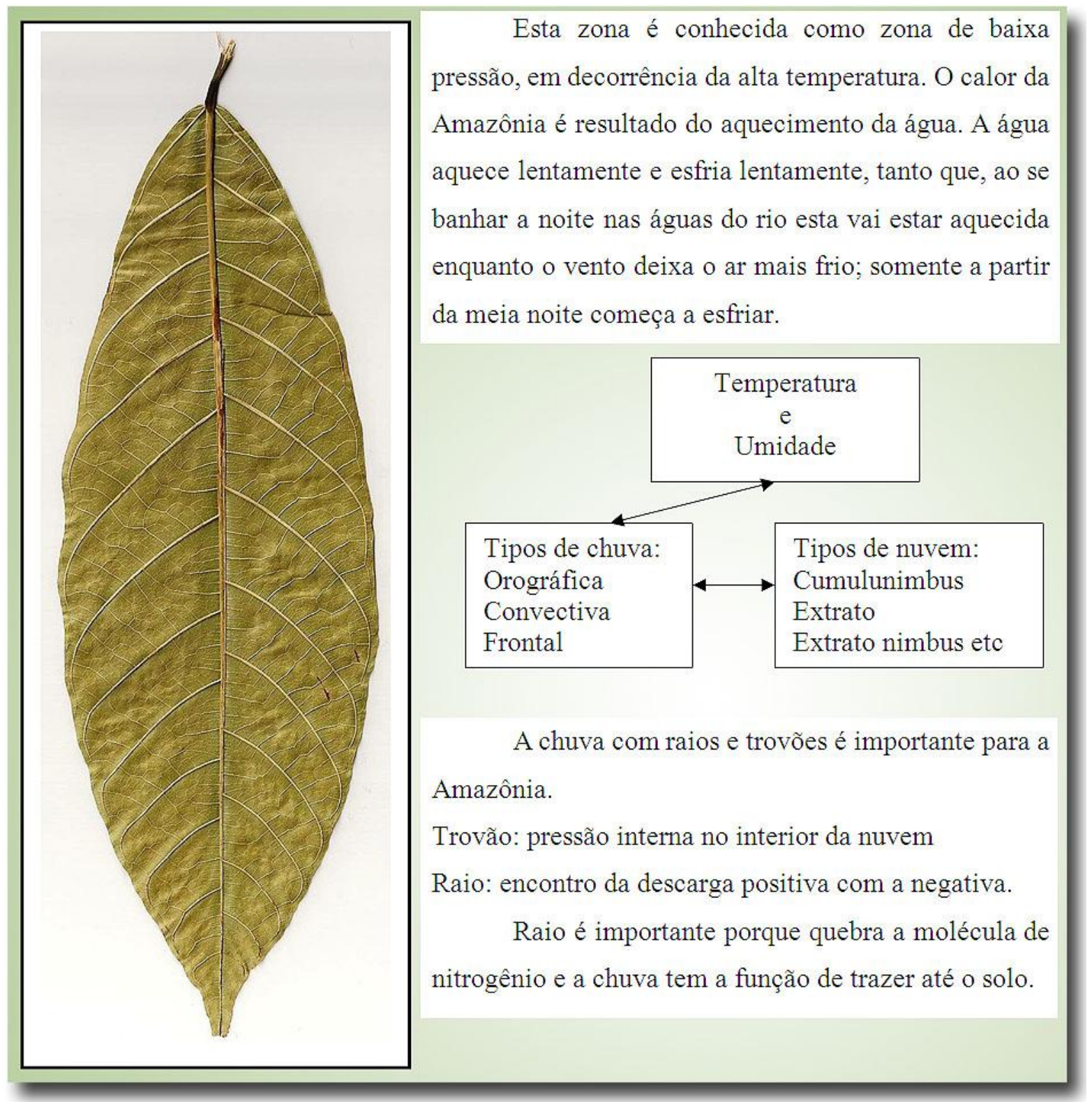

Figura 66 - Função da folha - Climatologia 
A água da chuva no solo executa a lixiviação ou a percolação. Esta água junto à camada de húmus - serrapilheira, transforma em nutriente no solo para a planta e também é alimento de insetos e da microfauna (mircrodecompositores).

Este encaminhamento permite estudar o solo e ver o perfil e as camadas; permite pensar o tipo de solo existente, como: arenoso, argiloso e os latossolos (SOUZA, 1991). Ao falar de solo o encaminhamento é dado à estrutura geológica e os tipos de rocha (GUERRA, 2003) e na sequência o relevo (GATTO, 1991), podendo ser visto nas bordas da folha o planalto, no meio a depressão e a planície nas proximidades das nervuras.

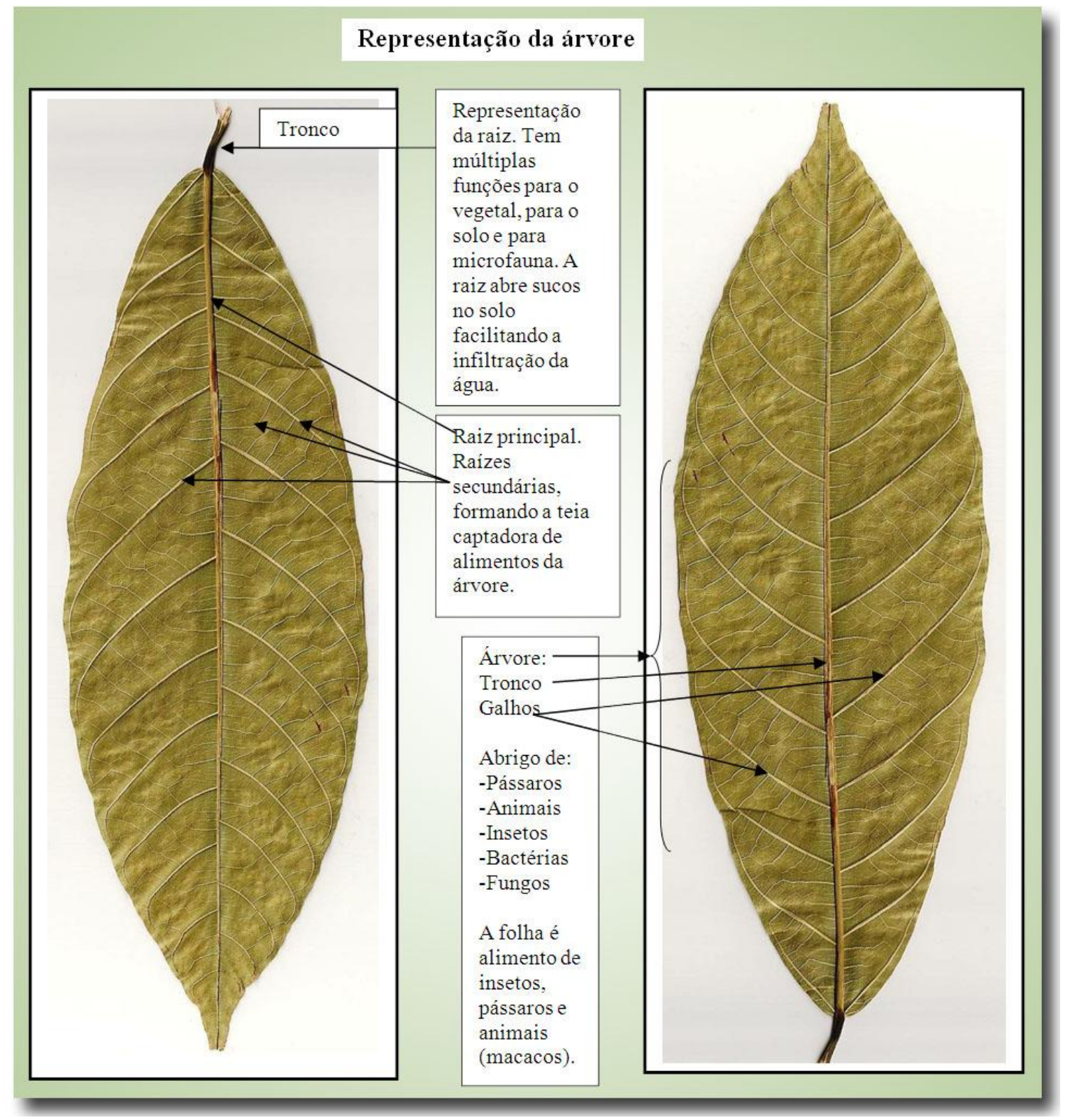

Figura 67 - Representação da árvore 
Há outras representações geográficas a serem vistas na folha, aguçadoras do imaginário e que auxiliam no exercício do pensar lógico e sistemático e, ainda, traduzem a realidade local em saber sobre aspectos hidrográficos da Amazônia.

O conjunto de nervuras da folha representa os inúmeros canais interligados formadores de bacia hidrográfica amazônica.

\section{Bacia Hidrográfica}

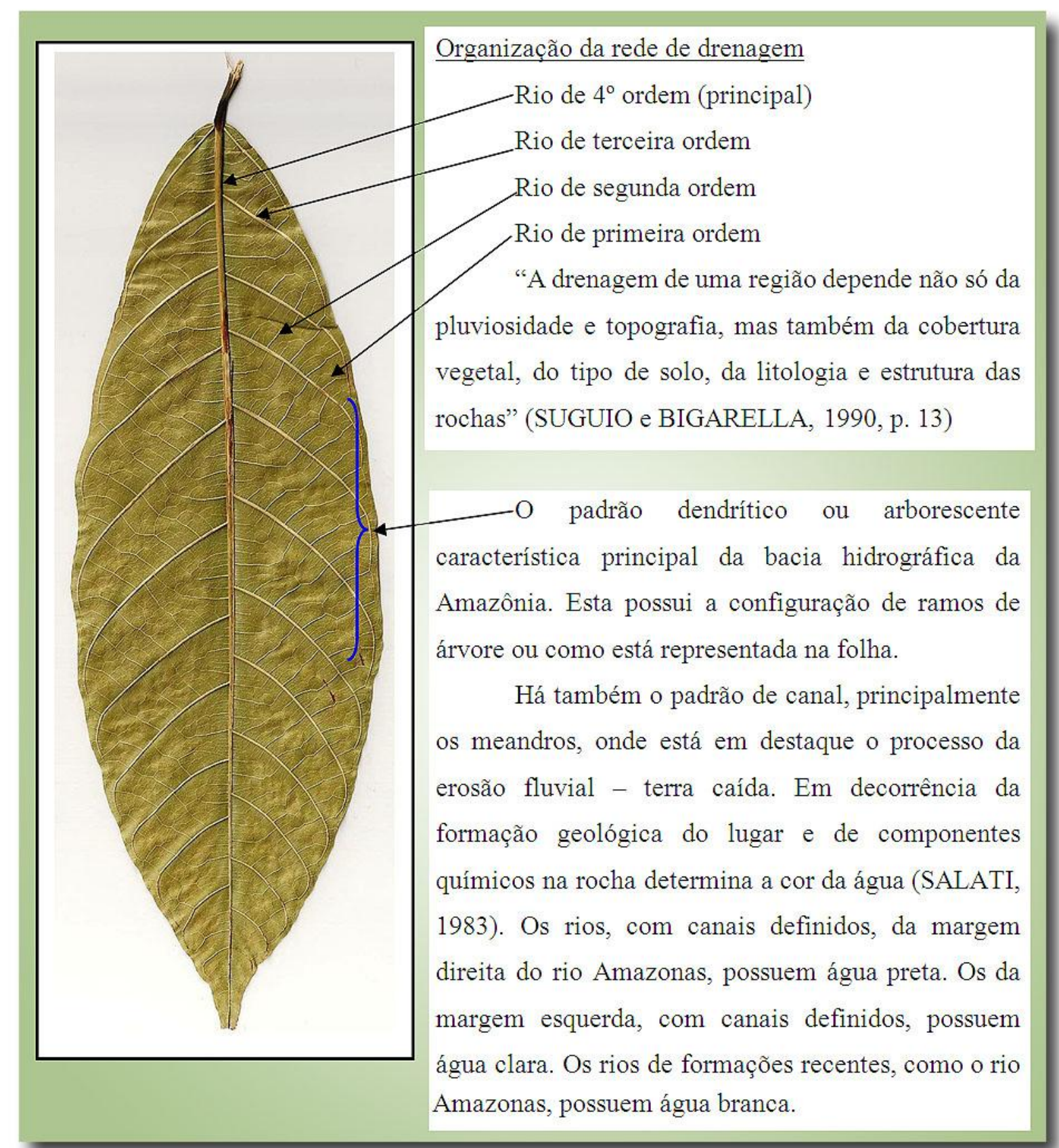

Figura 68 - Função da folha - Bacia Hidrográfica 
Esta leitura geográfica da folha conduz a um novo olhar. Este olhar é para ver o que há de mais regional representado na própria folha. Por isso, faz-se necessário exercitar o imaginário e trocando o olhar para ver outras representações, como: o meio de transporte.

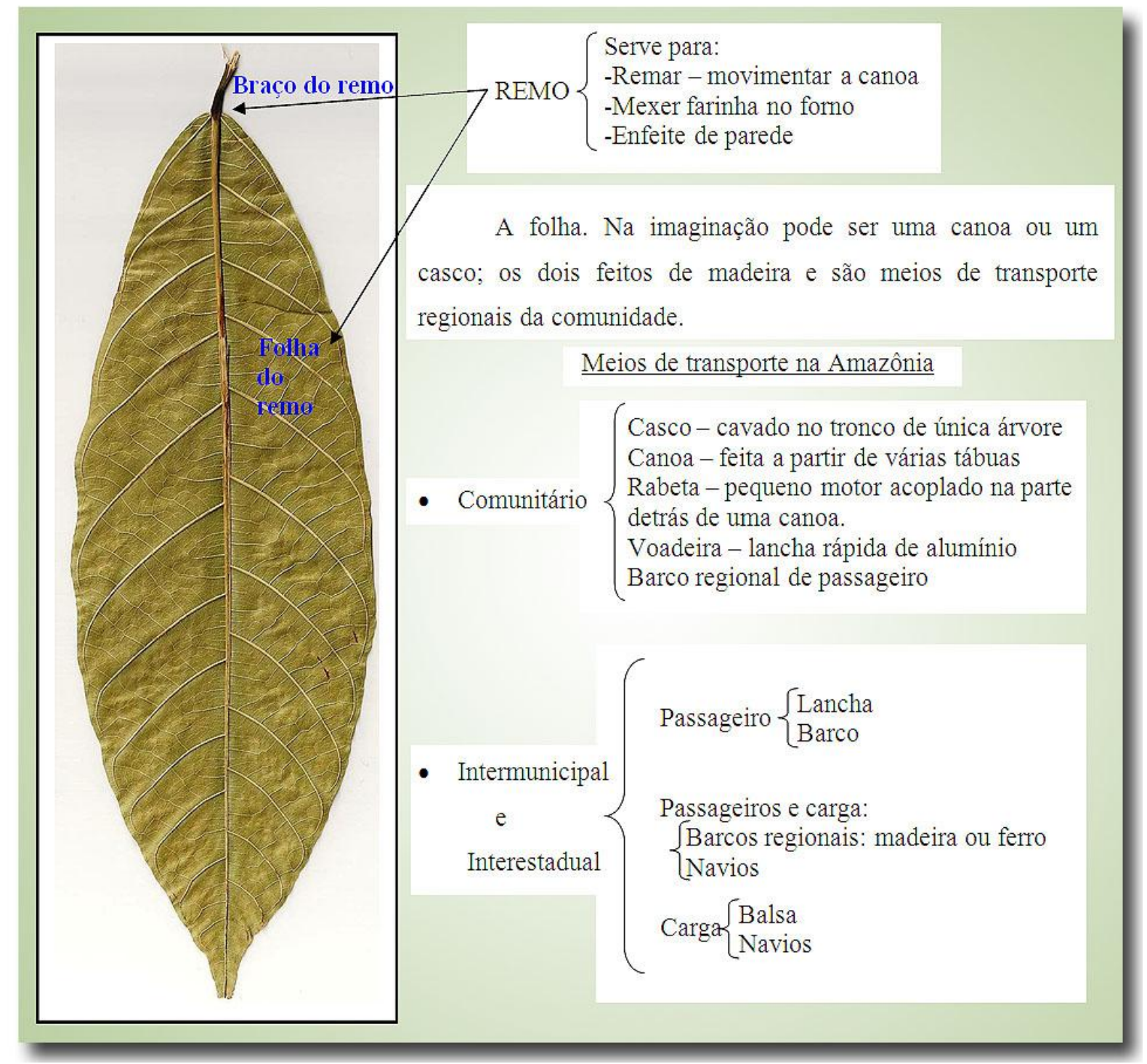

Figura 69 - Função da folha - Meios de Transporte

As nervuras da folha podem ainda representar as estradas ou rodovias da Amazônia: as municipais, as estaduais e as federais. Tem por finalidade ligar as cidades, os Estados e as regiões, facilitando o escoamento da produção e o abastecimento das cidades. 
Os rios e as rodovias foram responsáveis pela ocupação e estruturação urbana da Amazônia. O primeiro momento se deu pelo rio e o segundo pelas estradas. Por isso é possível visualizar, na folha, o processo de urbanização da Amazônia, sendo:

1. Pelos rios (período da colonização)

2. Por terra (abertura de estrada pelos militares, no sentido de "integrar para não entregar")

3. Povoamento:

- Povos nativos - aldeias - já existentes antes da chegada dos colonizadores.

- Comunidades - foram construídas ao longo dos rios.

- Vilas - novas estruturações urbanas (OLIVEIRA, 2000).

- Cidades - seguem o padrão dendrítico (CÔRREA, 1991; OLIVEIRA, 2000).

- Militares: Agrovila e Rurópolis (OLIVEIRA, 2000).

Seguindo as orientações de Suguio (1990) é possível perceber, na folha, a fisiografia da bacia, mas serão mostrados alguns padrões de drenagem.

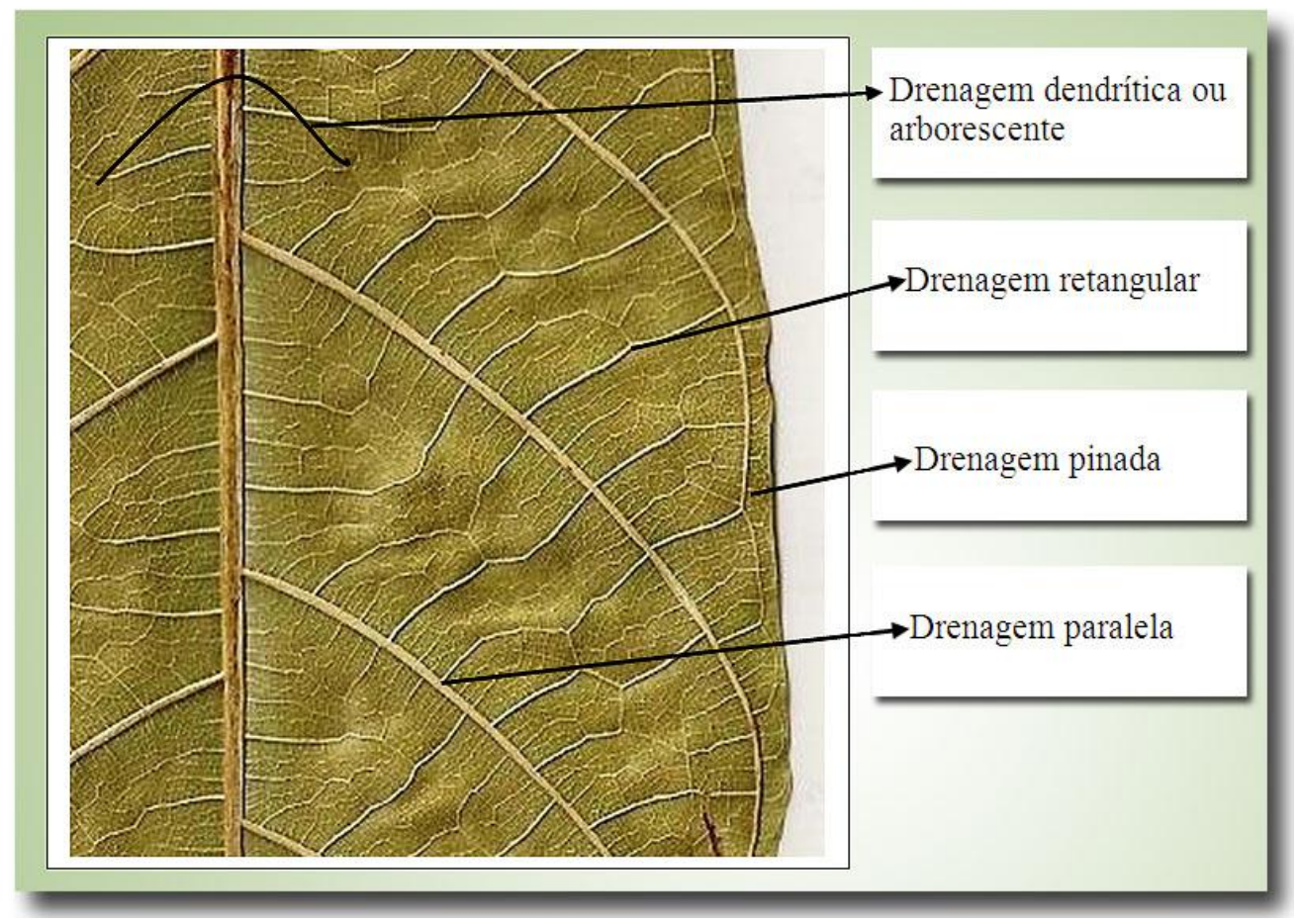

Figura 70 - Função da folha - Padrões de Drenagem 
Firmando o olhar, é possível ver a representação dos padrões de canais: retilíneo, anastomosado e meandrante. O padrão de escoamento configura na bacia exorréica, a qual destina suas águas para o mar, como a bacia amazônica. Nas endorréicas, segundo Seguio (1990, p.18) “[...] o escoamento é interno, isto é, não se faz para o oceano. Neste caso as águas fluem para uma depressão (playa ou lago) [...]”, podendo considerar as micro bacias internas, que circulam suas águas dentro das depressões amazônicas.

$\mathrm{Na}$ escola, foi repassada uma folha de um vegetal para cada estudante. Eles foram orientados a observar e depois dizer a geografia ou qualquer representação de seu dia-a-dia, por eles visualizados. Após uma hora de observação, tinham realizadas anotações nos seus cadernos e unanimemente falaram: "estamos vendo o telhado de uma casa". Então, foi solicitada a descrição de objeto visualizado, na folha e assim expuseram:

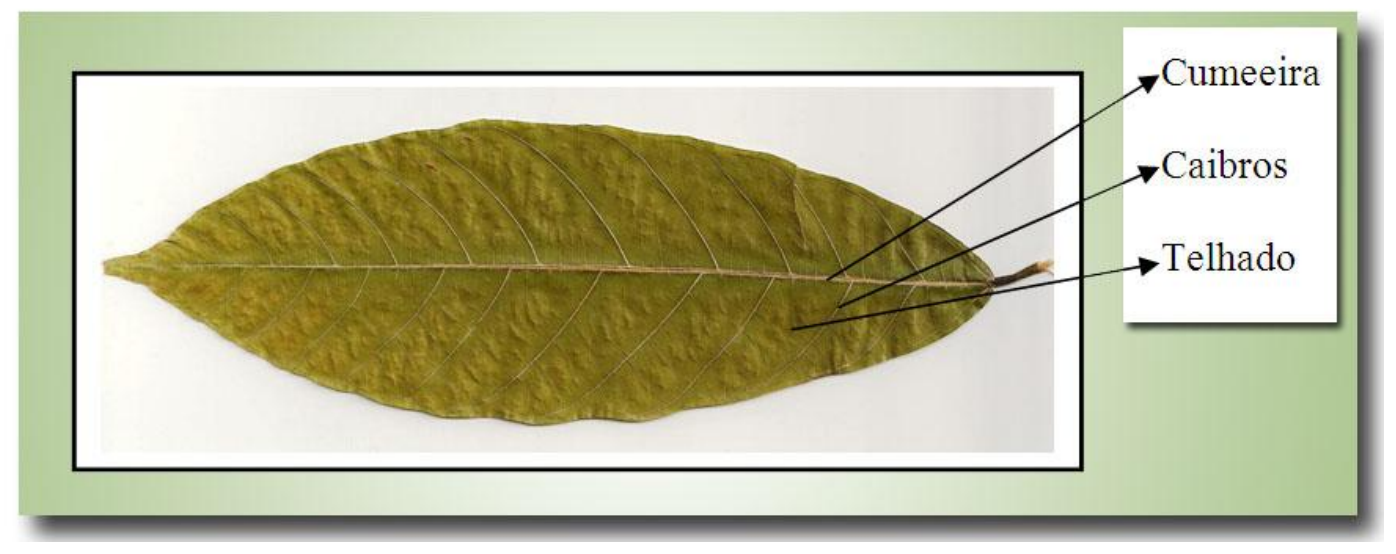

Figura 71 - Função da folha - Padrão das casas

Instigados a pensar nas possibilidades do que mais poderiam ver na folha falaram dos esteios que sustentam o telhado (palha ou telha) e o assoalhado de suas casas (palafitas) e de como resistem às enchentes. A partir deste momento foram apresentadas todas as possibilidades de ver a configuração geográfica descritas, estimulando cada vez mais o imaginário dos estudantes.

O que foi representado na folha está diretamente ligado à visão sistêmica do objeto pesquisado, o qual foi visto e visitado. O sentido é também expor caminhos de possibilidades para ensinar Geografia, porque o estudante conhece parte do que foi mostrado, pelos ensinamentos escolares e de seus pais. 


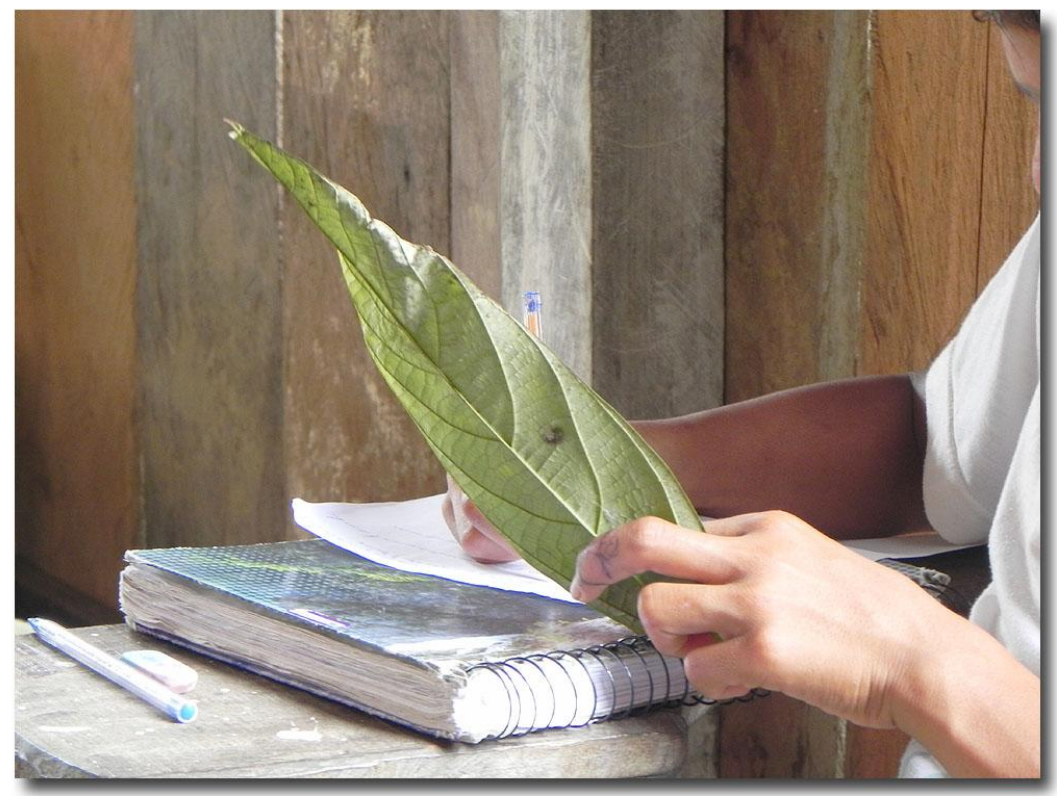

Figura 72 - aluno em atividade com a folha vegetal

A folha é a representação de um mapa mas, antes de ser, é a reflexão em si do conhecimento existente na Amazônia. Partindo de um exercício mental e fundamentado na base teórica da geografia vai sendo materializado, no sentido de sua construção como recurso de aprendizagem e ao mesmo tempo gerando um importante elemento significativo no saber construído pelo estudante das escolas ribeirinhas. É no contato direto que seus pais ensinam seus filhos a conhecer o seu lugar de vida e é na materialização dos conteúdos abstratos que a escola pode tornar o conteúdo trabalhado mais significativo.

Ema uma oficina interdisciplinar com Matemática e Educação Ambiental realizada com para os professores na escola Tiradentes, demonstrou-se outros meios de ensinar geografia utilizando frutos de árvores nativas da várzea existentes na própria comunidade, conhecida popularmente como castanha de macaco. 


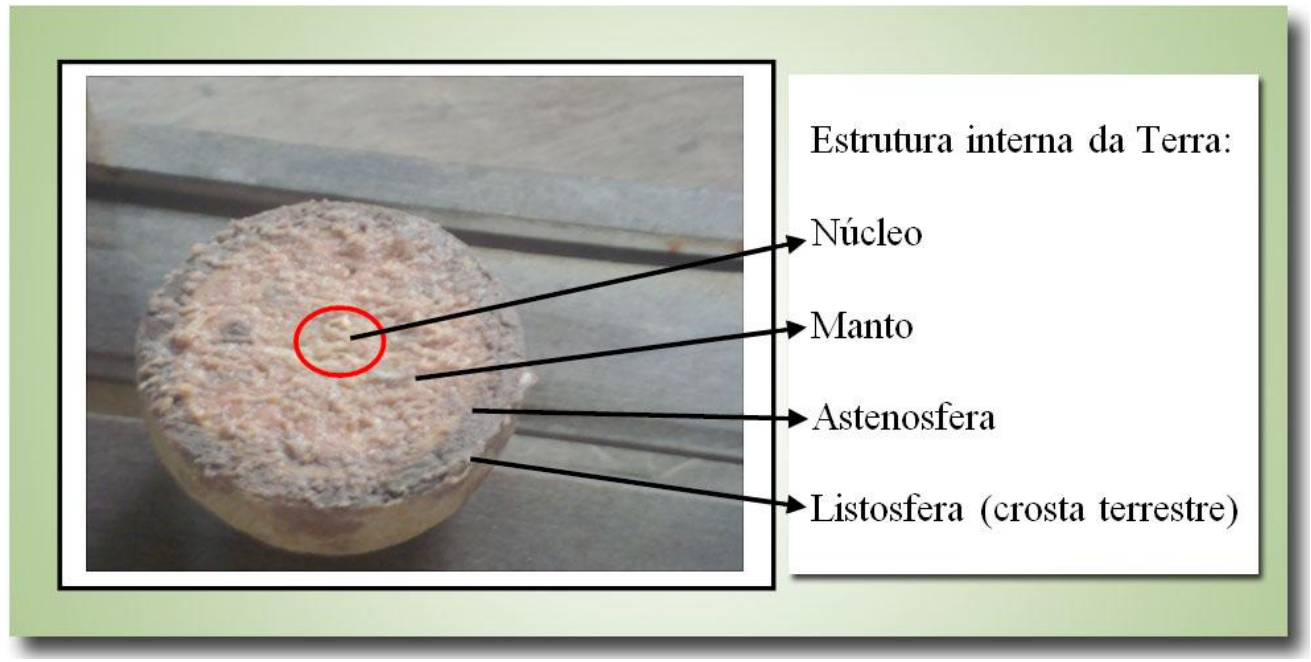

Figura 73 - Função da castanha de macaco - Estrutura interna da Terra

Após a demonstração da estrutura do interior da Terra e tecidos os comentários sobre a temperatura do interior do planeta, foi demonstrado a deriva dos continentes, o seu afastamento ano-a-ano e o atrito das placas tectônicas causadoras de abalos sísmicos. Para a demonstração, foi utilizado a parte de massa da própria castanha de macaco. Isto foi trabalhado em conjunto com a matemática, no uso da fração, círculo e circunferência.

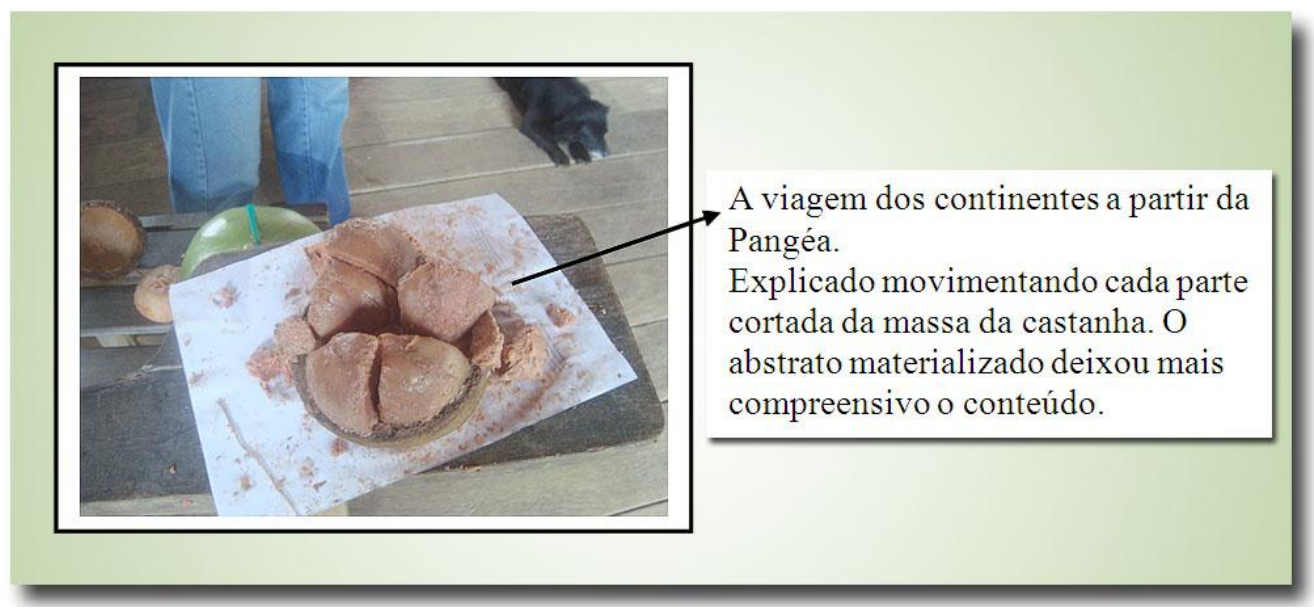

Figura 74 - Função da castanha de macaco - Deriva continental 
Outro recurso utilizado foi uma cuia como globo terrestre. Foi mostrada a forma da Terra e as possíveis divisões, como: zonas frias, zonas temperadas e zona tórrida. Demonstrou-se o movimento de rotação e como se forma o dia e a noite; o movimento de translação, determinante das estações do ano. A matemática trabalhou esfera e os elementos da esfera.

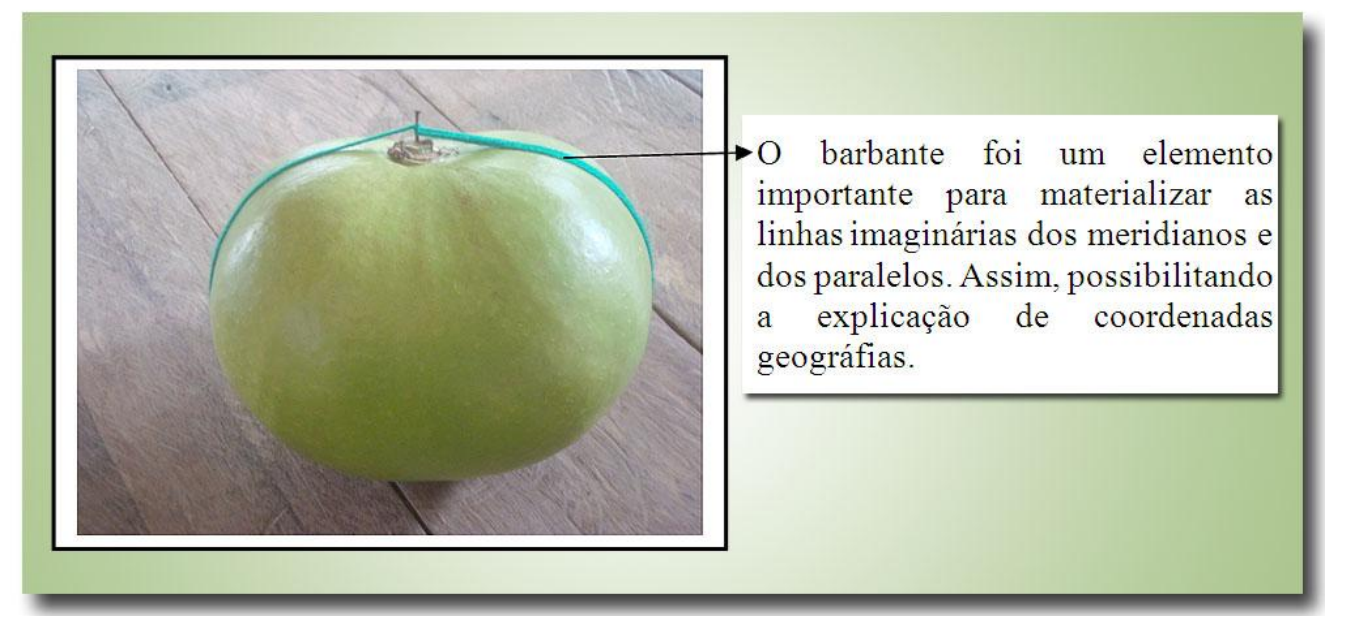

Figura 75 - Barbante e coordenadas geográficas

A metodologia consiste em o aluno ir construindo passo-a-passo, realizando as devidas anotações no seu caderno, sob a orientação do professor. Neste processo ocorre ensinoaprendizagem e avaliação do estudante.

Estes resultados, preliminarmente apresentados, são frutos das inquietudes que conduzem a tentativa da compreensão do fenômeno de articulação entre o currículo de geografia e os saberes tradicionais - presentes na história de vida dos estudantes que são sujeitos da escola ribeirinha do município de Parintins, protagonistas de seu aprendizado e da construção de sua própria história. Eles articulam e projetam suas vidas a partir dos impactos que são gerados nas suas representações do lugar vivido, como elo de resistência das imposições do externo, mas sem, contudo, deixar de viver as relações com que é produzido e processado globalmente. 
O que foi apresentado como proposta de recursos metodológicos são possibilidades para deixar o ensino de geografia mais próximo do aluno e da realidade vivida, principalmente quando se utiliza dos próprios recursos de ordem natural existentes na própria comunidade. Esta proposta para o ensino de geografia, instiga o professor e o aluno à exercitarem suas criatividades, dando sentido ao conteúdo trabalho pelo professor a aprendido pelo aluno. 


\section{CONCLUSÕES}

O percurso realizado na construção deste trabalho de tese está intimamente ligado à trajetória dentro da educação de Parintins e mais presente na percepção do ensino de Geografia nas escolas das comunidades ribeirinhas, distante dos conhecimentos construídos em tempos pretéritos e vividos e revividos em dias atuais, detentores do conhecimento do lugar e da geografia presente em cada comunidade do município de Parintins e da Amazônia.

Assim, esta tese reúne informações sobre a geografia das escolas das comunidades ribeirinhas, no sentido da compreensão do processo escolar de ensino-aprendizagem a fim de revelar os caminhos e as dificuldades vividas pelos professores, estudantes e comunitários nas construções de saberes formal e não-formal. Estes saberes e todo processo educativo dimensionam a geografia aprendida pelos estudantes, tanto na escola quanto na vivência diária.

O reflexo da construção da Amazônia e dos sujeitos construtores - o ribeirinho sobre a geografia existente, tanto na comunidade ribeirinha amazônica de várzea quanto na de terra firme, surgiu nas rodas de conversa por haver compreensão do modo de vida em cada lugar e se fazer presente nas traduções escritas neste trabalho de tese. A reflexão e questionamentos se estenderam ao currículo adotado nas escolas, ao cotidiano e aos saberes tradicionais ou historicamente construídos, que dimensionaram o ensino de Geografia na escola e permitiram leituras compreensivas sobre a tensão entre os saberes.

Os resultados apresentados correspondem ao processo de estruturação de um pensar lógico sobre a fundamentação do conhecimento construído nos percursos realizados pelas realidades das escolas de várzea e de terra firme e de abertura de novas possibilidades de ler e compreender a realidade de cada lugar de maneira a extrair compreensões do ensino de geografia escolar, posto que não dialoga com o saber existente e repassado de pai para filho.

Mencionar a inexistência do diálogo entre o saber geográfico ensinado na escola e o saber construído nas relações interpessoais - pais e filhos - seria óbvio. O que existe neste processo de ensino-aprendizagem é a negação, não no sentido de negar a existência, sim de ignorar o conhecimento empiricamente construído e ensinado às crianças pelos seus pais. Saber que foi experimentado, praticado e não está sendo associado ao conteúdo ensinado na escola. Se fosse trabalhada a construção do conhecimento geográfico a partir do saber existente na comunidade, sendo este enriquecido pelos conceitos e categorias geográficas, haveria a aplicação na vida prática de cada sujeito aprendente. 
Ressalta-se que esta negação se dá pelo desconhecimento por quem ensina na escola. Outro aspecto se deve em decorrência de não saber como realizar as transposições necessárias dos conteúdos geográficos para as realidades existentes. Assim, o saber adquirido pelos estudantes na vivência do trabalho no roçado e de atividades de pescaria não são aproveitados na sala de aula. Com isso, o ensino de Geografia continua seguindo as velhas lições das verdades contidas nos livros didáticos.

A geografia existente na comunidade ribeirinha, apesar de ser vivida pelos estudantes, ainda não é percebida porque não foi concebida e logo não pode ser utilizada porque se encontra na invisibilidade do saber e do desconhecimento de quem ensina, compondo o currículo oculto na comunidade e na escola.

Em termos de conteúdo, toda vegetação que compõe o quadro natural da comunidade e do entorno, pode ser trabalhada a partir da distribuição dos vegetais (fitogeografia) tanto da várzea quanto da terra firme, fazendo a diferença dos dois ambientes, como também os vegetais de várzea que se adaptam na terra firme e como alguns da terra firme conseguem se adaptar à sazonalidade do rio. Além destes aspectos de conteúdo, pode ser trabalhada a extinção dos vegetais associada a dos animais. Mostra-se como o vegetal é importante para a terra e na composição de floresta a sua forma de autossustentação (serapilheira ou camada de húmus), autoproteção (a heterogeneidade protege das pragas e impede a proliferação das mesmas), como se compõe dentro do sistema. Além de poder trabalhar a construção sociocultural e o desaparecimento de muitas espécies vegetais e animais, causada pela irracionalidade do uso. Assim, poder fazer um composto de conhecimentos interligados na construção da firmação da importância dos saberes tradicionais, enriquecendo os conhecimentos formais trabalhados em sala de aula.

Alternativas para se ensinar geografia nas escolas ribeirinhas existem, precisando despertar o olhar da criatividade do professor e que este se permita a construir conhecimentos a partir da relação sistêmica que envolve o viver e o existir, aproveitando todo recurso natural como recurso didático.

Ao verticalizar o olhar sobre o ensino de geografia nas escolas das comunidades ribeirinhas de Parintins e de outras escolas ou realidades educativas da Amazônia, as alternativas apresentadas, em todo percurso da tese, estão intimamente ligadas ao conhecimento de Geografia Agrária, quando envolve o sistema, o modo e a relação de produção. A Geografia Econômica, quando é praticado o escambo e outras formas de comercialização, encontrada por mulheres agricultoras e pescadoras. A Geografia do 
Transporte pode ser observada pela janela das casas e dos prédios escolares quando singra o rio os barcos de passageiros, barcos de transporte de carga e por grandes navios cargueiros e de turistas, além das pequenas embarcações utilizadas pelos comunitários. Basta saber ver a geografia do lugar e envolver nos conteúdos trabalhados nos anos escolares, ou seja, de $6^{\circ}$ ao $9^{\circ}$ ano, sempre fazendo a transposição do lugar para o regional, nacional e internacional ou global.

O professor, ousadamente, ainda poderia iniciar o trabalho dos conteúdos com questionamentos, para instigar o pensar do estudante: como é a produção agrícola no sudeste do Brasil? A forma de cultivar na Amazônia, no sudeste do Brasil seria igual à da Europa? Como o ribeirinho aprendeu a trabalhar com a terra (solo) entendendo a interpendência existente na Amazônia? Estes questionamentos são para dimensionar as inúmeras possibilidades de ensinar, associando os conteúdos geográficos às práticas trabalhadas pelos ribeirinhos, onde os seus filhos, estudante da escola, ajudam e aprendem a cultivar, a trabalhar o arranjo espacial da agricultura.

É nesta perspectiva do ensino na escola ribeirinha que se faz oportuno o apoderamento das características locais para enriquecer os conteúdos trabalhados em sala de aula e ao mesmo tempo fortalecer a representação de lugar, montando um quadro da formação étnica do amazônida e um quadro dos saberes tradicionais, no sentido de valorizar e fortalecer os conhecimentos secularmente transmitidos de geração a geração, perdurando até os dias atuais.

A negação ou a tensão entre os saberes estariam sendo minimizados e o ensino de geografia ganharia importância na vida de quem está aprendendo, porque saberia aplicar no fazer diário, seja no roçado, nas viagens por dentro das matas em busca de alimento ou de produtos para comercializar.

Nesta perspectiva conclusiva, o encaminhamento dado criaria alternativa para o redimensionamento da classe multisseriada - que ganharia importância pois os estudantes aprenderiam mutuamente, como processo dialógico, e construiriam conhecimentos coletivamente. Mantendo a estrutura atual da classe multisseriada, o resultado sempre será a negação porque o trabalho se dá de forma individualizada. Para o ensino avançar com melhoria, é necessário ousar no ato de ensinar geografia e também de outras disciplinas porque o intento é transpor o processo ensino-aprendizagem para interdisciplinar ou transdisciplinar. 
Na pequena vivência e observações na sala de aula e na escola, ficou evidente que o estudante não se sente parte integrante da escola, apenas vai e volta sem dar muito sentido e importância ao conteúdo apresentado em sala, pois o conteúdo estudado não tem sentido na sua vida. Não tem importância o que se estuda na escola por não conseguir manter relação do que é estudado com os afazeres diários. Assim, a escola não é parte integrante do estudante como este não se sente parte da escola. Apesar de estar dentro, sente-se distante e fora do espaço escolar. Nas escolas ribeirinhas todo conteúdo deveria ser a mola propulsora, não só de leitura compreensiva do mundo, mas além da leitura crítica sobre sua realidade. Saber utilizar determinados conhecimentos geográficos - principalmente o de orientação e localização - que, associados a todo conhecimento repassado pelos seus pais, daria segurança nos percursos pela mata, sejam de terra firme ou de várzea. Assim, o interesse pelo conteúdo estudado ganharia sentido e seria valorizada a aprendizagem.

Tudo pode ser discutido na sala de aula a partir da geografia existente na comunidade, relacionando o conhecimento adquirido na convivência do trabalho, da pescaria e nas lições dos seus pais, para o estudante passar a ter uma leitura crítica sobre as múltiplas realidades existentes frente à exploração dos recursos naturais da Amazônia e da cobiça internacional sobre essa região.

Toda informação deve ser canalizada para o ensino de geografia, no sentido de mudar a escola atual e, para tanto, poderia ser proposto ou estabelecido um roteiro de observações na beira do rio quando iniciasse a vazante e depois, sistematicamente, durante o período em que a várzea está totalmente emersa. E até o momento em que inicia a enchente para que o estudante possa perceber toda mudança ocorrida e assim estabelecer leituras e compreensões da dinâmica natural do rio e da várzea. Poderia também colocar uma estaca, como se fosse um metro, para ver quantos centímetros de sedimentos são depositados durante cada enchente.

$\mathrm{Na}$ terra firme o roteiro estaria voltado para a erosão pluvial, onde seria possível ver os perfis do solo e o tipo de material que o compõe. Também poderia ser estendido para trilhas na floresta e entorno da escola onde os estudantes perceberiam a variedade de vegetação e as inúmeras populações de insetos, fungos e outros componentes da floresta, agindo ativamente na manutenção da cadeia alimentar e do sistema amazônico. Nesta trilha poderiam ser chamados alguns pais para acompanharem o grupo e assim fazerem a identificação dos vegetais e suas propriedades fitoterápicas. Os pais, nessa participação, estariam demonstrando os saberes que possuem sobre o lugar e o que nele existe. 
A escola, tanto da água como da terra e floresta, poderia trabalhar com projeto, construindo um herbário com o registro da vegetação local. Também propor o levantamento, feito por estudantes, em um metro quadrado de área, com o intuito analisar tudo que perceberem, tanto em termos de vegetação quanto em termos de micro fauna.

O projeto seria mais uma alternativa para dinamizar o ensino, porque abriria diálogo com a Secretaria de Educação no sentido de possibilitar intercâmbio entre os estudantes das escolas ribeirinhas e os da cidade (e vice-versa), bem como visitas sistematizadas entre estudantes das escolas de várzea com os das escolas de terra firme.

Assim estará construindo um ensino de geografia mais cheio de significados e significantes, tornando-o mais interessante, mais atrativo e valorizado por cada sujeito aprendente porque passará dar maior sentido ao processo da aprendizagem. Importante ressaltar que os conteúdos praticados obterão maior poder de apreensão mental e, por consequência, possibilitarão autonomia ao estudante no seu exercício prático de vida.

Os conteúdos contidos na proposta curricular e apresentados nas tabelas, por ano escolar, por estarem fragmentados e não comunicando a continuidade, não permitem aos estudantes - até por falta de determinados recursos didáticos na escola - a alfabetização em Geografia, ou seja, não conseguem dominar os conceitos básicos de lugar e de todas as categorias geográficas, não entendendo a sua própria relação com a natureza. No contexto cartográfico, por falta de mapas e globo na sala de aula, na ausência do domínio da transposição da cartografia científica para a escolar, conduz o estudante a manter deficiência na leitura e compreensão de mapas, até por falta de contato com esses recursos didáticos. Como resultado, o sentido de orientação e de localização vai ser prejudicado e não saberão aplicar na prática. Em consequência dessa deficiência do ensino, o estudante não compreenderá a dinâmica da sociedade na transformação do espaço e, com este, a sua própria transformação.

Qual o ensino de geografia existente? Qual o ensino de geografia que se pretende ter? Quais as mudanças que se quer obter? É possível realizar mudanças?

Estes questionamentos são condutores de outras reflexões sobre a realidade escolar, de várzea e terra firme, que foi vivenciada durante inúmeras viagens e tendo como princípio a observação de toda geografia existente no percurso realizado pelo rio Amazonas até as comunidades-base da realização da pesquisa. Percurso realizado por muitos estudantes quando vão à cidade ou quando estão nas pescarias com seus pais, momento em que aprendem observando e vão assimilando os ensinamentos transmitidos através dos diálogos. 
O que foi observado pode e deve ser os grandes passos para discussões acerca da Geografia fora do livro didático e assim pensar em mudanças no ensino, construindo alternativas concretas de mudanças, que apesar de toda dificuldade enfrentada pelo professor de escola ribeirinha, podem processar aulas diferentes por dominarem os conceitos e as teorias da Geografia.

O barco do transporte escolar ou o ônibus poderiam representar um lugar de aprendizagem se fossem equipados com bibliotecas. Poderiam ser utilizados para pequenas excursões em que os estudantes pudessem experimentar na prática os conteúdos estudados. Nesses meios de transporte escolar seria o transporte dos sedentos por conhecimento e o líder, professor, seria o maestro dessa orquestra de aprendizagem e de construção de conhecimentos.

Esses professores, heróis da beira do rio, possuem graduação, alguns em Geografia e os que não são da área, sempre pedem auxílio, principalmente em conteúdos que não dominam. Por serem necessários, deveriam ser mantidos cursos de curta duração e de formação contínua aos professores de formação pedagógica, que ministram aulas de geografia nas escolas ribeirinhas.

No encaminhamento de todas as propostas para o ensino de geografia, nunca deve ser deixado à margem as experiências de vida dos estudantes de várzea e de terra firme, porque podem enriquecer os conteúdos com suas experiências e assim poderão viver projeções de seus futuros, poderão construir seus espaços de vida e de esperança, por se tornarem construtores de saberes a partir de suas dificuldades, de seus conflitos nas relações cotidianas de aprendizagem e por estarem instigados a se transformar em eternos aprendizes. Na vida em construção, cada lugar é de aprendizagem - para que se possa construir um lugar ideal de vida por perceber e conceber a importância do aprender continuamente. A realidade da aprendizagem está registrada nas respostas e nos desenhos projetados no papel a partir do vivenciado. Demonstrando assim, o saber construído socialmente e cotidianamente.

Cada resultado apresentado permitiu refletir sobre a importância do ensino de Geografia na vida de cada estudante. Porém, para se alcançar um resultado mais positivo é necessária à construção de um currículo que contemple as propostas dos atores educativos e de todos os sujeitos da aprendizagem, que anseiam por um currículo de significados e condutor de compreensão do espaço vivido. 
Como sempre, na Amazônia ou no Amazonas, tudo que pode dar autonomia ao ribeirinho é desfeito, como ocorreu com o projeto Educação para o Meio Rural do Amazonas. No processo de ensino e defesa da escola, as resistências devem ser mantidas para se construir coletivamente uma escola diferente para estudantes ribeirinhos diferentes.

As respostas a todos os questionamentos - ou as que faltaram nesta tese - só poderão ser dadas com o avanço de novas pesquisas. Porém, estes resultados são ensaios de discussões para possíveis mudanças na estrutura de escola ribeirinha do Amazonas e ousadamente da Amazônia. Assim sendo, espera-se que as novas pesquisas possam trazer novas contribuições para as escolas ribeirinhas, no sentido de discutir e construir o currículo participativo, a escola integradora e multicultural, o ensino de geografia possuidor de comunicação com outras áreas do conhecimento, para o fortalecimento do sentimento de identidade do estudante ribeirinho e valorização do saber tradicional ou historicamente construído, repassado aos mais jovens. 


\section{REFERÊNCIAS}

ALMEIDA, Alfredo Wagner Berno de [et al.]. (Orgs.). Conhecimento tradicional e biodiversidade: normas vigentes e propostas. $2^{\mathrm{a}}$ ed. - Manaus: PPGAS-UFAM/ NSCACESTU - UEA Edições, 2010.

ALMEIDA, Rosângela Doin de (Org.). Novos rumos da cartografia escolar: currículo, linguagem e tecnologia/ organização Rosângela Doin de Almeida. São Paulo: Contexto, 2011.

Paulo: Contexto, 2007.

Cartografia escolar. Rosângela Doin de Almeida, (organizadora). São Do desenho ao mapa: iniciação cartográfica na escola / Rosângela

Doin de Almeida. 2. ed. São Paulo: Contexto, 2003 - (Caminhos da Geografia).

AMORIM, Marília. O pesquisador e seu outro: Bakhtin nas ciências humanas/ Marília Amorim. - São Paulo: Musa Editora, 2004.

APPLE, M. W. Repensando ideologia e currículo. In: MOREIRA, A.F. e SILVA, T. T. da. Currículo, cultura e sociedade. $4^{\mathrm{a}}$ ed. São Paulo, 2000.

Conhecimento oficial: a educação democrática numa era conservadora / Machael W. Apple; tradução de Maria Isabel Edelweiss Bujes. - Petrópolis, RJ: Vozes, 1997.

ALVES, Laura Maria Silva Araújo. A tradição oral na Amazônia: a mitopoética dos espaços nas narrativas de encantamentos, visagens e assombrações. In. ALVES, Laura Maria Silva Araújo... [et al.]. Cultura e educação: reflexões para a prática docente. Belém: EDUFPA, 2008.

BATISTA, Djalma. Amazônia - cultura e sociedade. / Djalma Batista; organização de Tenório Teles - Manaus: Editora Valer / Governo do Estado do Amazonas / Editora da Universidade Federal do Amazonas, 2003.

BETTANINI, Tonino. Espaço e ciências humanas / Tonino Bettanini; tradução de Liliana Laganá Fernandes; revisão técnica de Moacyr Marques. - Rio de Janeiro: Paz e Terra, 1982. (Coleção Geografia e sociedade; v. 2).

Brasil. [Lei Darcy Ribeiro (1996)]. LDB : Lei de Diretrizes e Bases da Educação Nacional : lei no 9.394, de 20 de dezembro de 1996, que estabelece as diretrizes e bases da educação nacional. - 5. ed. - Brasília : Câmara dos Deputados, Coordenação Edições Câmara, 2010.

BRASIL. Secretaria de Educação Fundamental. Parâmetros curriculares Nacionais: Geografia. Brasília: MEC/SEF, 1998.

CALLAI, Helena Copetti. Aprendendo a ler o mundo: a geografia nos anos iniciais do ensino fundamental. In. Cadernos Cedes. Educação geográfica e as teorias de aprendizagens. Campinas, vol. 25, n. 66, p. 129 - 272, maio/ago. 2005. 
Do ensinar geografia ao produzir o pensamento geográfico. In. REGO, Nelson, AIGNER, Carlos, PIES, Cláudio e LINDAU, Heloísa (Orgs.). Um Pouco do Mundo cabe nas Mãos; Geografizando em Educação o local e o global. Porto Alegre: Editora da UFRGS, 2003.

CASTELLS, Manuel. O poder da identidade. Tradução Klaus Brandini Gerhardt. $3^{\text {a }}$ ed. São Paulo: Paz e Terra, 2002.

CASTROGIOVANNI, Antonio Carlos... [et al.]. Geografia em sala de aula: práticas e reflexões. Porto Alegre: Editora da UFRGS/ Associação dos Geógrafos Brasileiros - Seção Porto Alegre, 2003.

CAVALCANTI, Lana de Souza. O ensino de geografia na escola. Campinas, SP: Papirus, 2012 - (Coleção Magistério: Formação e trabalho pedagógico).

A geografia escolar e a cidade: Ensaios sobre o ensino de geografia par a vida urbana cotidiana./ Lana de Souza Cavalcanti. - Campinas, SP: Papirus, 2008 (Coleção Magistério: Formação de Trabalho Pedagógico).

Cotidiano, mediação pedagógica e formação de conceitos: uma contribuição de Vygotsky ao ensino de geografia. In. Cadernos Cedes. Educação geográfica e as teorias de aprendizagens. Campinas, vol. 25, n. 66, p. 129 - 272, maio/ago. 2005.

Geografia, escola e construção do conhecimento/ Lana de Souza

Cavalcanti. - Campinas, SP: Papirus, 1998 - (Coleção Magistério: Formação e trabalho pedagógico).

CLAVAL, Paul. Terra dos homens: a geografia / Paul Claval; tradução Domitila Madureira. São Paulo: Contexto, 2010.

CORRÊAA, Roberto Lobato Corrêa. A organização urbana. In. Instituto Brasileiro de Geografia e Estatística, Diretoria de Geociências. Geografia do Brasil: Região Norte. volume 3. Rio de Janeiro: IBGE, 1991.

COSTA, Marisa Vorraber (Org.). O currículo nos limiares do contemporâneo. 4. edição. Rio de Janeiro: DP\&A, 2005.

CRUZ, Manuel de Jesus Masulo da. Territorialização camponesa na várzea da Amazônia. São Paulo, 2007. 274 f. (Doutorado em Geografia) - Faculdade de Filosofia e Ciências Humanas - Departamento de Geografia, Universidade de São Paulo, São Paulo, 2007.

DARDEL, Eric (1899-1967). O homem e a terra: natureza da realidade geográfica / Eric Dardel: tradução Werther Holzer. - São Paulo: Perspectiva, 2011.

DOLL Jr., William E. Currículo: uma perspectiva pós-moderna / William E. Doll Jr.; trad. Maria Adriana Veríssimo Veronese. - Porto Alegre: Artes Médicas, 1997.

FERNANDES, Manoel. Reflexões sobre a investigação em história da formação de professores de geografia. In. PONTUSCHKA, Nídia Nacib e OLIVEIRA, Ariovaldo Umbelino (orgs.).Geografia em perspectiva: ensino e pesquisa. São Paulo: Contexto, 2002. 
FRAGO, Antonio Viñao e ESCOLANO, Agustín. Currículo, espaço e subjetividade: a arquitetura como programa. / Antonio Viñao Frago e Agustín Escolano: [tradução Alfredo Veiga-Neto]. - 2. edição - Rio de Janeiro: DP\&A, 2001.

FRAXE, Therezinha de Jesus Pinto et.al. (Org.). A pesca na Amazônia Central - Ecologia, conhecimentos tradicionais e formas de manejo/ Therezinha de Jesus Pinto Fraxe, Antônio Carlos Witkoski e Suzy Cristina Pedroza da Silva (Organizadores). Manaus: Editora da Universidade Federal do Amazonas, 2009.

Paulo: Annablume, 2004.

Cultura cabocla-ribeirinha: mitos, lendas e transculturalidade. São

FREIRE, Paulo. Pedagogia da autonomia: saberes necessários à prática educativa / Paulo Freire. - São Paulo: Paz e Terra, 1996 (Coleção Leitura).

FREITAS, Maria Natalina Mendes. O ensino de Ciências em Escolas Multisseriadas na Amazônia ribeirinha: um estudo de caso no Estado do Pará. / Maria Natalina Mendes Freitas; Orientadora, Terezinha Valim Oliver Gonçalves. - Belém: [s.n.], 2005. 113f.:il Monografia (Mestrado). - Universidade Federal do Pará, Núcleo Pedagógico de Apoio ao desenvolvimento Científico, 2005.

FRÉMONT ARMAND. A região, espaço vivido. Tradução de António Gonçalves e revisão de António Gama Mendes. Coimbra - Portugal: Livraria Almedina, 1980.

GADOTTI, Moacir. Educação integral no Brasil: inovação em processo. São Paulo: Editora e Livraria Instituto Paulo Freire, 2009. - (Educação Cidadã, 4).

Reinventando Paulo Freire na escola do século 21. In. TORRES, Carlos Alberto... [et al.]. Reinventando Paulo Freire no século 21. São Paulo: Editora e Livraria Instituto Paulo Freire, 2008. - (Série Unifreire).

GATTO, Luis Carlos Soares. Relevo. In. Instituto Brasileiro de Geografia e Estatística, Diretoria de Geociências. Geografia do Brasil: Região Norte. Volume 3. Rio de Janeiro: IBGE, 1991.

GHEDIN, Evandro (Org.). Currículo, avaliação e gestão por projetos no ensino médio. Manaus: Editora Travessia/Seduc, 2007.

Por uma revisão dos processos educativos escolares. In. GHEDIN,

Evandro (Org.). Currículo, avaliação e gestão por projetos no ensino médio. Manaus: Editora Travessia/Seduc, 2007.

GOMEZ, Rodriguez Gregório. Metodologia de investigación Cualitativa. 2ed. Málaga: Aliibe, 1996.

GONZAGA, Amarildo Menezes. Currículo r sociedade: relevância e abrangência no processo de construção do sentimento de identidade. In. SOARES, Ana Paulina A. [et al] (Org.). Temas Introdutórios às Ciências da Educação / Universidade do Estado do Amazonas. Escola Normal Superior. Manaus: INCRA, 2004. 
GOODSON, Ivor R. Currículo: teoria e história / Ivor F. Goodson; tradução de Attílio Brunetta; revisão da tradução: Hamilton Francischetti; apresentação de Tomaz Tadeu da Silva. - Petrópolis, RJ: Vozes, 1995. - (Ciências sociais da educação).

GUERRA, Antônio Teixeira. Novo dicionário geológico-geomorfológico / Antônio Teixeira Guerra e Antonio José Teixeira Guerra - $3^{\mathrm{a}}$ ed. - Rio de Janeiro: Bertrand Brasil, 2003.

HALL, Stuart. A identidade cultural na pós-modernidade / Stuart Hall; tradução Tomaz Tadeu da Silva, Guaraeira Lopes Louro - 10. ed. - Rio de Janeiro: DP\&A, 2005.

JACOBI, Pedro Roberto. Prefácio. In. PASSADOR, Cláudia Souza. A educação rural no Brasil: o caso da Escola do Campo no Paraná. São Paulo: Annablume, 2006.

JUNK, Wolfgang Johannes. As águas da região amazônica. In SALATI, Enéas (org.). Amazônia: Desenvolvimento, Integração e Ecologia. São Paulo - SP: Editora Brasiliense S/A., 1983.

KIMURA, Shoko. Geografia no ensino básico: questões e propostas. São Paulo: Contexto, 2008.

MARANDOLA Jr., Eduardo, HOLZER, Werther, OLIVEIRA, Lívia de (Orgs). Qual o espaço do lugar?: geografia, epistemologia, fenomenologia. São Paulo: Perspectiva, 2012.

MARTINS, Cinthya da Cruz. Espacialidade e saber: a nucleação das escolas rurais de Nova Olinda do Norte - Amazonas / Manaus, 2002. 175 f. (Mestrado em Sociedade e Cultura na Amazônia) - Instituto de Ciências Humanas e Letras - Programa de Pós-Graduação em Sociedade e Cultura na Amazônia, Universidade Federal do Amazonas, 2002.

MATURANA, Humberto. A ontologia da realidade. Humberto Maturana; Cristina Magro; Mirian Graciano e Nelson Vaz: organizadores - Belo Horizonte: Ed. UFMG, 1997.

MEINERZ, Carla Beatriz. Fazendo referência à vida: a escola como espaço de diálogo entre memórias individual e coletiva. In. REGO, Nelson, MOLL, Jaqueline e AIGNER, Carlos (Org.); HEINDRICH, Álvaro Luiz... [et al.]. Saberes e práticas na construção de sujeitos e espaços sociais. Porto Alegre: Editora da UFRGS, 2006.

MERLEAU-PONTY, Maurice. Fenomenologia da percepção. (tradução Carlos Alberto de Moura) $-3^{\mathrm{a}}$ ed. - São Paulo: Martins Fontes, 2006. - (Tópicos)

MINAYO, Maria Cecília de Souza (org.). Pesquisa social:teoria, método e criatividade. $23^{\mathrm{a}}$ ed. Petrópolis, RJ: Vozes, 2004.

MONTEIRO, Carlos Augusto de Figueiredo. O mapa e a trama: ensaios sobre o conteúdo geográfico em criações romanescas/ Carlos Augusto de Figueiredo Monteiro. - Florianópolis: Ed. Da UFSC, 2002.

MORAES, Sérgio Cardoso de. Fragmentos de saberes tradicionais. In. ALVES, Laura Maria Silva Araújo... [et al.]. Cultura e educação: reflexões para a prática docente. Belém: EDUFPA, 2008a. 
. Comunidades rurais-ribeirinhas: processos de trabalho e múltiplos saberes. In. OLIVEIRA, Ivanilde Apoluceno de (Org.). Cartografias Ribeirinhas: saberes e representações sobre práticas sociais cotidianas de alfabetizandos amazônicos / Org. Ivanilde Apoluceno de Oliveira. $2^{a}$ Edição. Belém: EDUEPA, 2008b.

NODA, Hiroshi e NODA, Sandra do Nascimento. Produção agropecuária. In. Amazônia, uma proposta interdisciplinar de Educação Ambiental. Temas básicos. Brasília: IBAMA, 1994.

NODA, Sandra do Nascimento (Org.). Agricultura Familiar na Amazônia das Águas. Manaus: Editora da Universidade Federal do Amazonas, 2007.

NOGUEIRA. Amélia Regina Batista. A geograficidade dos comandantes de embarcação no amazonas. In. Amazônia... Terra Livre. Goiânia. Ano 22, v. 1, n. 26. Jan-Jun/2006.

. Mapa mental: recurso didático para o estudo do lugar. In. PONTUSCHKA, Nídia Nacib e OLIVEIRA, Ariovaldo Umbelino (orgs.).Geografia em perspectiva: ensino e pesquisa. São Paulo: Contexto, 2002.

Mapa mental: recurso didático no ensino de geografia no $1^{\circ}$ grau. São Paulo, 1994. 171 f. (Mestrado em Geografia) - Faculdade de Filosofia e Ciências Humanas Departamento de Geografia, Universidade de São Paulo, São Paulo, 1994.

OLIVEIRA, Inês Barbosa de. Currículos praticados: entre a regulação e a emancipação. Rio de Jeneiro: DP\&A, 2003.

OLIVEIRA, José Aldemir de. Cidades na Selva. - Manaus: Editora Valer, 2000.

PACHECO JÚNIOR, Israel e TORRES, Michelangelo Marques. Atualidade do pensamento de Paulo Freire na educação popular. In. ASSUMPÇÃO, Raiane (Org.). Educação popular na perspectiva Freiriana. São Paulo: Editora e Livraria Instituto Paulo Freire, 2009. - (Educação popular; 3 ).

PINHEIRO, Maria do Socorro Dias. Currículo e seus significados para os sujeitos de uma escola ribeirinha multisseriada do Município de Cametá - Pará; orientador, Prof. Dr. Salomão Antônio Muffarrej Hage. _ 2009. Dissertação (Mestrado em Educação) Universidade Federal do Pará, Instituto de Ciências da Educação, Programa de PósGraduação em Educação, Belém, 2009.

PONTUSCHKA, Nídia Nacib. Para ensinar e aprender Geografia/ Nídia Nacib Pontuschka, Tomoko Iyda Paganelli, Núria Hanglei Cacete. $1^{a}$ ed. - São Paulo: Cortez, 2007 - (Coleção docência em formação. Série ensino fundamental).

O conceito de estudo do meio transforma-se... em tempos diferentes, em escolas diferentes, com professores diferentes. In.VESENTINI, José William (org.). $O$ ensino de Geografia no século XXI. Campinas, SP: Papirus, 2004.

REGO, Nelson... [et al.]. Um pouco do mundo cabe nas mãos; Geografizando em educação o local e o global. Porto Alegre: Editora da UFRGS, 2003. 
ROMÃO, José Eustáquio. Sistemas municipais de educação: a Lei de Diretrizes e Bases (LDB) e a educação no município / José Eustáquio Romão. - São Paulo: Editora e Livraria Instituto Paulo Freire, 2010. - (Educação cidadã; 5).

ROSENDAHL, Zeny e COORÊA, Roberto Lobato (Orgs.). Geografia: Temas sobre cultura e espaço. Rio de Janeiro: EdUERJ, 2005.

SACRISTÁN, J. Gimeno. O currículo: uma reflexão sob a prática. 3ed. Porto Alegre: Artes Médicas, 1998.

SALATI, Enéas (org.). Amazônia: Desenvolvimento, Integração e Ecologia. São Paulo - SP: Editora Brasiliense S/A., 1983.

SANTOS. L. L.C.P e MOREIRA, A. F. Currículo: questões de seleção e organização do conhecimento. In: Caderno Idéias. N.26, FDE. São Paulo, 1996.

SEEMANN, Jörn. A aventura cartográfica: perspectivas, pesquisas e reflexões sobre a cartografia humana / Jörn Seemann (org.). Fortaleza: Expressão Gráfica e Editora, 2005.

SEMPRINI, Andrea. Multiculturalismo./ Andrea Semprini; tradução Laureano Pelegrin. Bauru, SP: EDUSC, 1999.

SERRANO, Glória Perez. Investigación Cualitativa. Retos e Interrogantes. Madrid: La Muralla S. A., 1994.

SCHÄFFER, Neiva Otero... [et al.]. Um globo em suas mãos: práticas para a sala de aula. 2.ed. - Porto Alegre: Editora da UFRGS/ Núcleo de Integração Universidade \& Escola da PROEXT/ UFRGS, 2005.

SHUBART, Herbert Otto Roger. Ecologia e utilização das florestas. In. SALATI, Enéas (org.). Amazônia: Desenvolvimento, Integração e Ecologia. São Paulo - SP: Editora Brasiliense S/A., 1983.

SILVA, Gláucia Oliveira da. Água, vida e pensamento: um estudo de cosmovisão entre trabalhadores da pesca. In. DIEGUES, Antônio Carlos. A imagem das águas. São Paulo: HUCITEC, 2000.

SILVA, Tomaz Tadeu da. Identidade e diferença: a perspectiva dos estudos culturais/ Tomaz Tadeu da Silva (org,). Stuart Hall, Kathryn Woodward. 10. ed. - Petrópolis, RJ: Vozes, 2011.

Documentos de identidade: uma introdução às teorias do currículo. 2. ed., 9a reimp. - Belo Horizonte: Autêntica, 2005.

Teoria cultural e educação: um vocabulário critico. Belo Horizonte:

Autêntica, 2000.

SOUZA, Celso Gutemberg. Solos. In. Instituto Brasileiro de Geografia e Estatística, Diretoria de Geociências. Geografia do Brasil: Região Norte. Volume 3. Rio de Janeiro: IBGE, 1991. 
SOUZA, José Camilo Ramos de. Parintins e Vila Amazônia: uma história de construção de vida urbana de imigrantes nipônicos. In. HOMMA, Alfredo Kingo Oyama; FERREIRA, Aldenor da Silva; FREITAS, Marilene Corrêa da Silva e FRAXE, Therezinha de Jesus Pinto. Imigração japonesa na Amazônia: contribuição na agricultura e vínculo com o desenvolvimento regional. Manaus: EDUA, 2011.

O mito e a escola de várzea. In. Caderno Educação, Cultura e Desafios Amazônicos/ Universidade Federal do Amazonas. Faculdade de Educação. Programa de PósGraduação. - vol. 1. N.1 (jan/dez. 2005) -, - Manaus: Editora da Universidade Federal do Amazonas, 2005.

SOUZA, José Gilberto de. Geografia e conhecimentos cartográficos. A cartografia no movimento de renovação da geografia brasileira e a importância do uso de mapa / José Gilberto de Souza, Ângela Massumi Katuta. - São Paulo: Editora UNESP, 2001.

STERNBERG, Hilgard O'Reilly. A água e o homem na várzea do Careiro/ Hilgard O'Reilly Stemberg. - 2.ed. - Belém: Museu Paraense Emílio Goeldi, 1998.

STRAFORINI, Rafael. Ensinar geografia: o desafio da totalidade-mundo nas séries iniciais / Rafael Straforini - São Paulo: Annablume, 2004.

SUGUIO, Kinitiro. Ambiente fluvial./Kinitiro Suguio; João José Bigarella. - 2. ed. Florianópolis: Editora da Universidade Federal do Paraná, 1990.

TRIVIÑOS, Augusto Nibaldo Silva. Introdução à pesquisa em ciências sociais: a pesquisa qualitativa em educação. São Paulo: Atlas, 1987.

TUAN, Yi-Fu, 1930 -. Espaço e lugar: a perspectiva da experiência / Yi-Fu Tuan; tradução de Lívia de Oliveira. - São Paulo: Editora UNESP, 2005.

Paulo: DIFEL, 1983.

-. Paisagens do Medo / Yi-Fu Tuan; tradução de Lívia de Oliveira. - São

-. Topofilia: um estudo da percepção, atitudes e valores do meio

ambiente / Yi-Fu Tuan; tradução de Lívia de Oliveira. - São Paulo: DIFEL, 1980.

WAGLEY, Charles. Uma comunidade amazônica: estudo do homem nos trópicos/ Charles Wagley; tradução de Clotilde da Silva Costa. - 3. ed. Belo Horizonte: Itatiaia; São Paulo: Editora da Universidade de São Paulo. 1988.

TYLER, Ralph. Princípios básicos de currículo e ensino. Porto Alegre: Globo, 1974.

WITKOSKI, Antonio Carlos. Terras, florestas e águas de trabalho: os camponeses amazônicos e as formas de uso de seus recursos naturais. Manaus: Editora da Universidade Federal do Amazonas, 2007. (Série: Amazônia: a terra e o homem).

VESENTINI, José William. Realidades e perspectivas do ensino de Geografia no Brasil. In.VESENTINI, José William (org.). O ensino de Geografia no século XXI. Campinas, SP: Papirus, 2004. 


\section{APÊNDICE}

\section{UNVERSIDADE DE SÃO PAULO \\ UNIVERSIDADE DO ESTADO DO AMAZONAS \\ DOUTORADO EM GEOGRAFIA FÍSICA}

Comunidade:

Localidade:

Escola:

Data:

Série:

Turma:

Turno

Nome do aluno (Opcional) Idade:

COMUNIDADE

O que é comunidade?

Você gosta de viver na sua comunidade? Sim ( ) Não ( )

Se gosta, por que?

Se não gosta, por que?

Você conhece sua comunidade? Sim ( ） Não ( )

Se conhece, descreva sua comunidade. 
Descreva o que existe ao redor (entorno) de sua comunidade.

Como está organizada sua comunidade em estrutura física e socialmente?

CASA

Como é sua casa?

De que é feita sua casa? Descreva-a.

O que existe no terreiro (quintal) de sua casa?

Descreva o lugar que você mora.

ESCOLA

O que é escola? 
Você conhece sua Escola?

O que leva a conhecer sua escola?

Como você vive na escola?

Como a Escola contribui na melhoria de sua vida?

ASPECTOS GERAIS

O que é várzea para você?

O que existe na várzea?

O que é terra firme para você? 
O que existe na terra firme?

Qual a diferença entre várzea e terra firme?

O que é rio para você?

O que você faz no rio?

O que é lago para você?

O que você faz no lago?

O que é ilha para você? 
Explique como se forma a ilha?

DESENHE A SUA COMUNIDADE

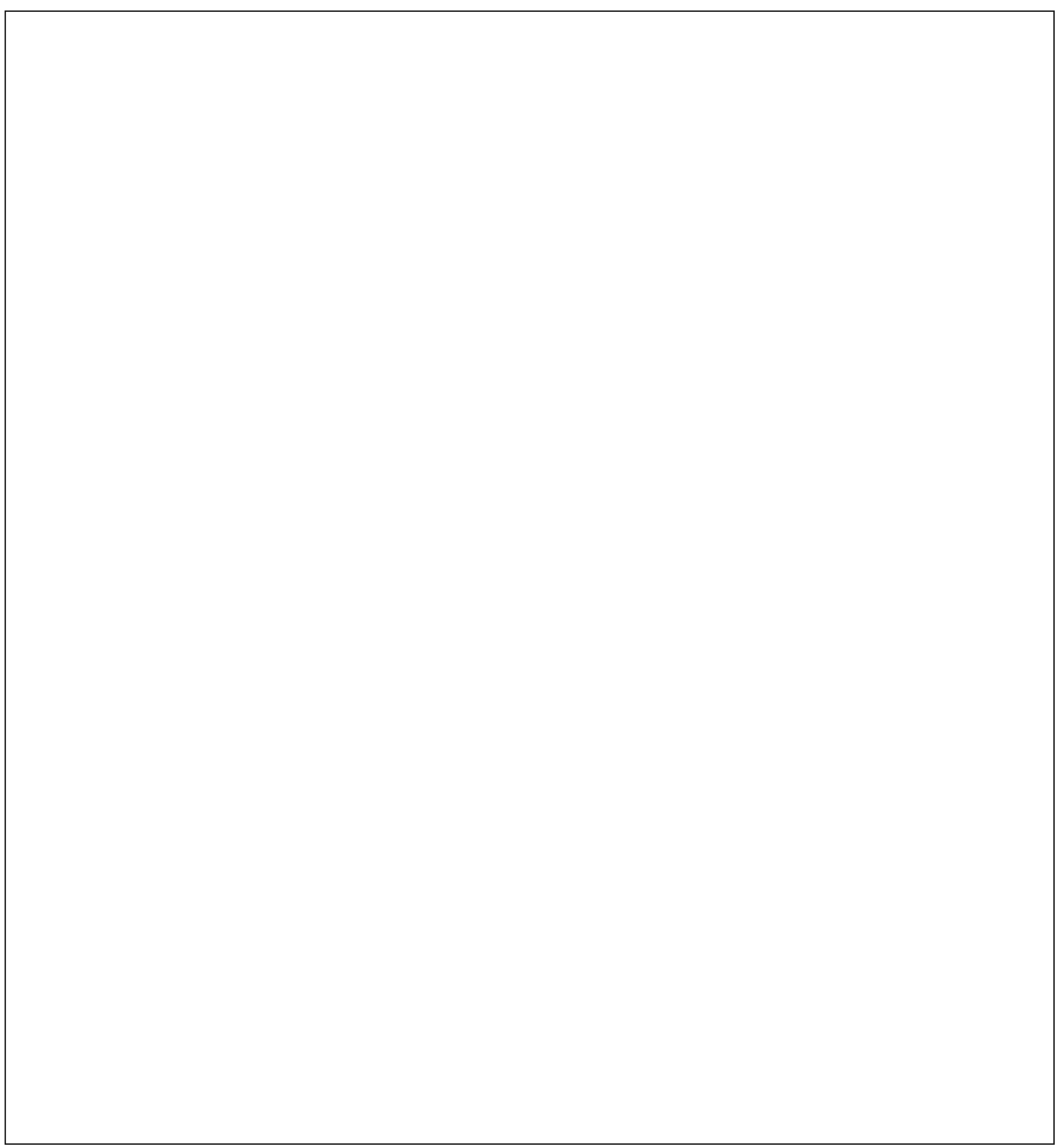


DESENHE A SUA ESCOLA E O QUE EXISTE AO REDOR

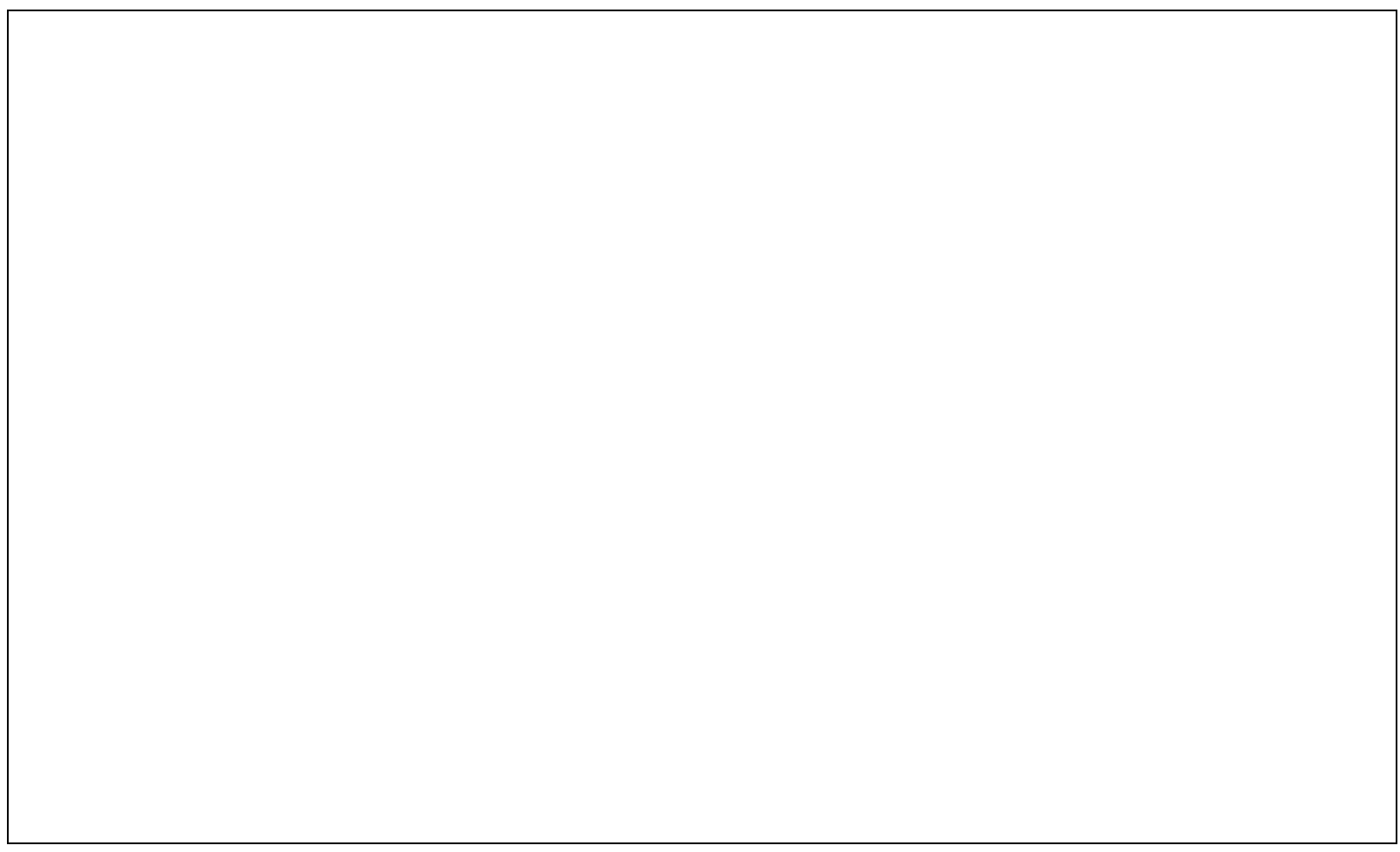

DESENHE SUA CASA E O QUE EXISTE AO REDOR

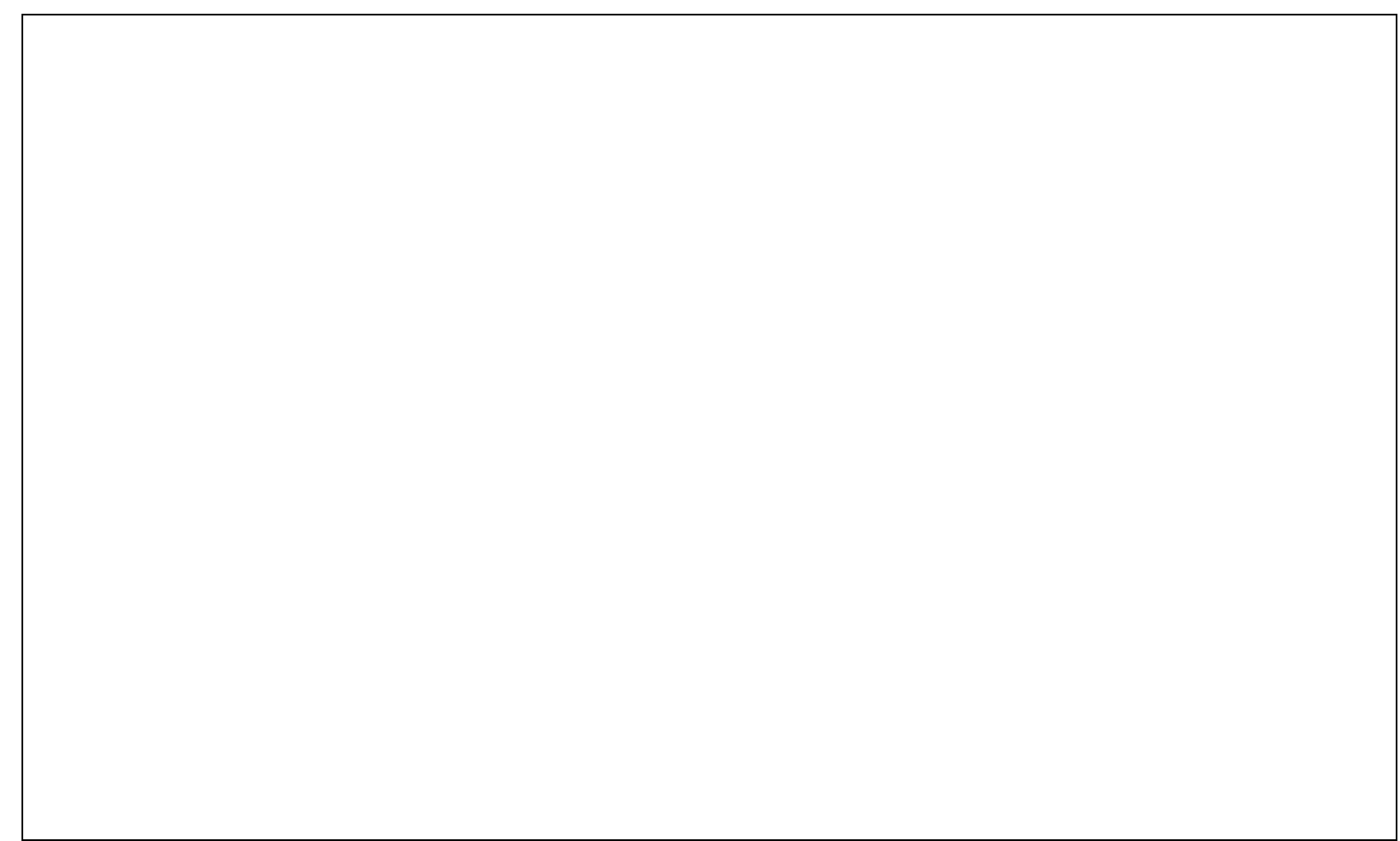


REPRESENTE EM FORMA DE DESENHO: VÁRZEA, TERRA firme, RIO AMAZONAS, LAGO E ILHA ( COMO SE FOSSE UMA HISTÓRIA EM QUADRINHOS)

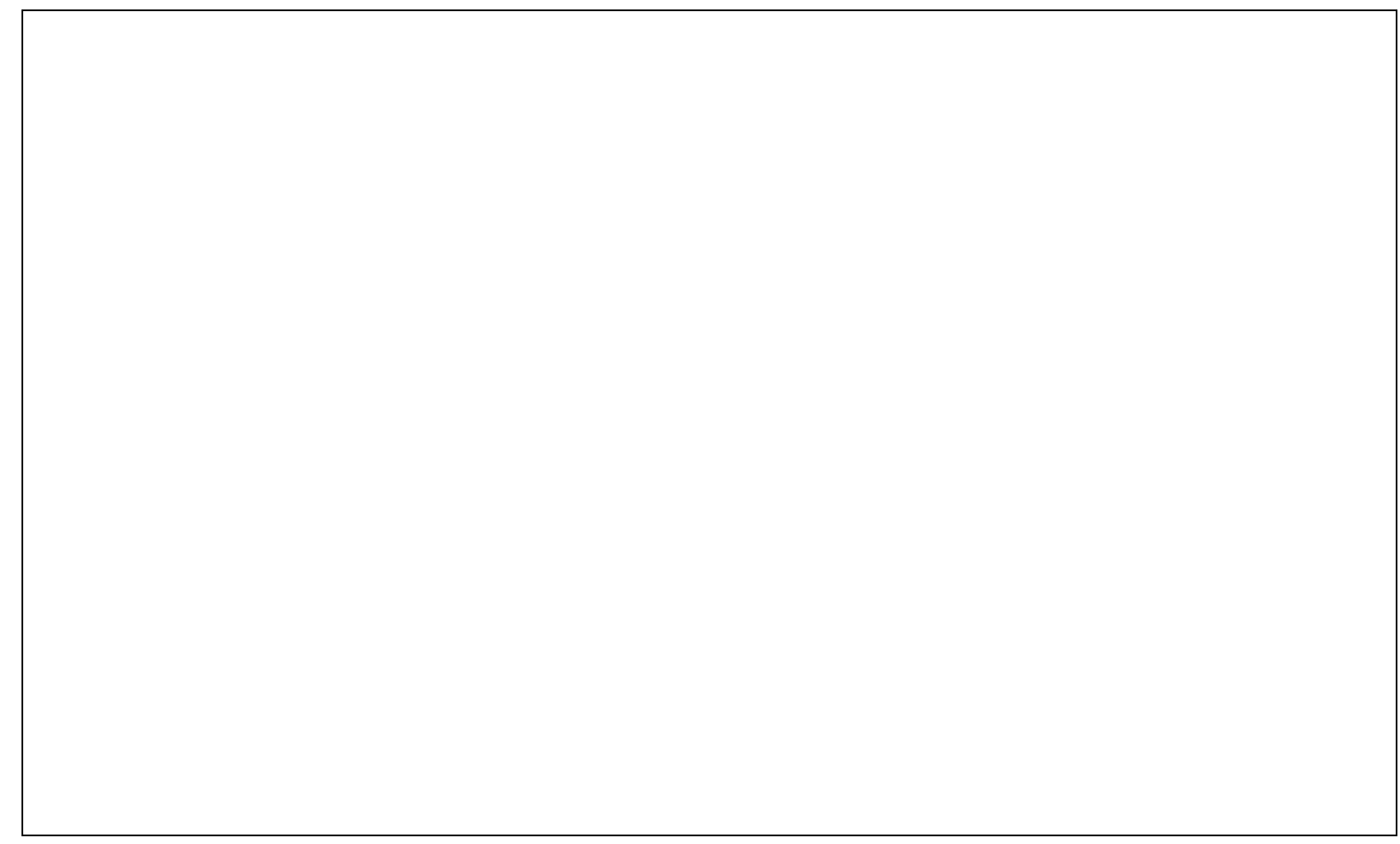




\section{ANEXOS \\ ENTREVISTAS COM RIBEIRINHOS}

\section{Dona Francisca}

JC: E aí, Dona Francisca, a senhora mora quanto tempo aqui?

Francisca: Uns... estou com 43 anos, desde quando nasci...

JC: Você é daqui mesmo?

\section{Francisca: (...)}

JC: E como era naquele tempo que você tava crescendo?

Francisca: era um pouco diferente de tudo de hoje. Porque... tem tempo. Quando a gente não tinha assim... Tempo que não tinha bolsa-escola então tinha que trabalhar (...) a gente não tinha os pais pra ajudar nós (...) às vezes estudava. A nossa merenda às vezes quando tinha peixe, levava (...) tirava lá do terreno de dna. Vanda. Seis horas da manhã, chegava 5 h da tarde, ficava o dia todo - só tinha a hora de meio-dia, pegava uma hora.

JC: o peixe é cru?

Francisca: Não, assava cedo, levava assado já (...)

JC: E aí, o peixe assado ia no prato, ia como?

Francisca: ia no prato mesmo!

JC: Punha na lata com a farinha...

Francisca: Ia no prato indo com a farinha...

JC: É...

???: Levava na lata...

JC: Eu também levava na lata, pirarucu enfiado na farinha...

Francisca: E agora não! Hoje é diferente porque as meninas tem o bolsa-escola, já tem mais que estudar mesmo sem estar se afastando da escola. Não se afasta, já tem merenda, só se afasta em caso de doença...

JC: O que é a merenda lá das escola?

Francisca: Feijão, arroz... suco de caju

JC: Mas por que não faz o mingau de jerimum?

Francisca: Porque agora tá meio "russo"

JC: Mas por que ficou "russo"?

Francisca: Porque assim - olha - quando planta, o gado do pessoal... os donos não tem um cuidado, em várias "pontas" e acaba tudo, não tão nem aí. Se for cobrar um pagamento, eles ficam com raiva da gente. Eles não querem ser amigo um do outro. Eles querem só ser inimigo porque eles não querem ajudar um ao outro. A gente vai - quando destrói e come tudo - a gente vai cobrar, eles ficam com raiva... 
JC: aí tá esta briga...

Francisca: Pra não ter briga é melhor acalmar e nem mais mexer com nada...

JC: E naquele tempo que a senhora estudava, lá pequenininha, a senhora ia de canoa ou ia pelo caminho?

Francisca: Canoa! Por terra quando era longe...

JC: Mas a senhora ia remando?

Francisca: a remo mesmo! neste tempo não tinha este negócio de "rabeta"...

JC: No remo?

Francisca: No remo mesmo!

JC: Quando volta de lá, vinha na vela?

Francisca: Hum... no remo de novo!

JC: Mas depois que comia dava aquela preguiça? Tinha que chegar em casa?

Francisca: Não!!! Tinha que chegar em casa. Chegava só de tarde...

JC: E a água pra tu (...) beira, como é que era? Trazia em que?

Francisca: Assim... vasilha mesmo, "carote”, balde. Mas este tempo só usava um balde de cuia...

JC: E aí, as cuieiras, cadê?

Francisca: As águas que "levaram"... Tem algumas agora...

JC: Mas não faz mais balde de cuia?

Francisca: Bem difícil. Agora é só "carote" pra carregar...

JC: Fica mais fácil. E aí, a senhora aprendeu a pescar naquele tempo?

Francisca: Só com malhadeira. Só bota a malhadeira...

JC: Ensinou ele a pescar com malhadeira?

Francisca: Ele sabe sim. Ficamos sem pai. Era só mamãe e aí, a situação. E tinha esta (...) que era menor. Minha sobrinha que... Minha irmã mais velha procurou, eu tinha que trabalhar (...) pra ajudar eles, que estavam tudo pequeno. Tinha que pescar, trabalhar, fazer a farinha... Tudo tinha que fazer no (...)

JC: A farinha? Plantava aqui a mandioca?

Francisca: Era aqui mesmo.

JC: mandioca ou macaxeira?

Francisca: Mandioca mesmo.

JC: E produzia a farinha aqui. Então a senhora sabe fazer a farinha?

Francisca: Sei sim.

JC: E quem lhe ensinou?

Francisca: Foi minha mãe mesmo...

JC: Mas a senhora mexia com remo, cuiapé, rodo...?

Francisca: Era remo, cuiapé, rodo... 
JC: Ai fazia aquele mexido assim com o remo e que jogava lá em cima, caí metade fora e metade dentro...

Francisca: Tudo dentro! Sei fazer piracuí... tudo eu sei.

JC: Piracuí de bodó?

Francisca: sim senhor! Só que eu não gosto porque corta muito a mão da gente

JC: Como é que é? Conte aí com se faz o piracuí?

Francisca: Assa o peixe, assa o bodó, descasca tudo, bate bem a massa. E coloca no forno. Conforme vai mexendo, vai tufando. Quando mais o piracuí tufa... e fica bonito o piracuí...

JC: O forno que vocês usavam antes, era do que, de barro ou de ferro?

Francisca: Era de ferro. Agora é de camburão.

JC: Nunca usaram forno de barro aqui?

Francisca: Não.

JC: E os meninos sabem fazer o piracuí?

Francisca: Esses não.

JC: Mas não aprenderam?

Francisca: Não. Só eu e o pai deles que ia fazer...

JC: E qual o tempo que faz piracuí?

Francisca: Este tempo já tá dando de fazer...

JC: Já tem piracuí pronto aí?

Francisca: Não. Porque já foi vendido. Que já fizeram e já venderam e agora vamos parar de vender (risos)

JC: Chegamos atrasados (risos) E agora, Zé? Temos que comer só a farinha... E o que a senhora cultiva aqui ainda? O que a senhora tá plantando?

Francisca: aqui não plantam não. É que eu estou lançando lá em cima. Porque era para eu já estar plantando mas é que capaz de morrer, o sistema fica afastado da cidade. Eu não tava por aqui... (...) Eu estou lá em cima pra plantar jerimum (...)

(???): Onde é lá em cima que a senhora fala? Pra lá da comunidade?

Francisca: É!!!

JC: Macaxeira vocês não plantam mais?

Francisca: É bem difícil!

JC: Maxixe? Quiabo?

Francisca: É difícil tudo! Teve quiabo, maxixe... tudo foi difícil!

JC: Me diga uma coisa: quando começa a encher, como é que fica a vida de vocês aqui?

Francisca: Quando começa a encher, fica uma dificuldade assim para os meninos. Eles vão na aula, quando já tá enchendo, já vão pela lama... Às vezes o transporte tem que levar lá fora, quando ela não 
pára. Pra quem estuda a noite, eles vão "à casco". Quem ainda estuda de dia, vai pela lama até pegar o barco e chegar na escola.

JC: E quando tá cheião já, próximo ao assoalho, vocês ficam aqui ou vão embora pra terra firme?

Francisca: Fica aqui mesmo. Quando vai só aí no fundo, faz maromba por cima.

JC: Como é a maromba?

Francisca: Só um lado (...) rolo de pau...

JC: E aí, tem algum problema?

Francisca: (...) Dá cobra...

JC: Cobra? Sucuruju?

Francisca: Não (...) estas que dão debaixo do assoalho...

JC: Mas cria galinha?

Francisca: Crio lá e tem lá em cima...

JC: E quando enche, a galinha vai pra onde?

Francisca: Vai pro galinheiro...

JC: Fica lá em cima, pendurada...

Francisca: É arriscado muito porque tem muito jacaré... porque quando vão pra beira... esta coisa de pegar... (...)

JC: E a (...)

Francisca: Não existe por aqui...

JC: Cobra grande?

Francisca: Só jacaré agora na beira.

JC: Só jacaré. Quer dizer que aquela história do boto virar homem, não se enxerga?

Francisca: Não

JC: Mas nunca ouviu falar?

Francisca: Existe mas por aqui não acontece.

JC: Nas outras comunidades acontece?

Francisca: Não sei.

JC: Vocês vendem na balsa, produto?

Francisca: Não.

JC: Mas tem pessoa que aqui vende?

Francisca: Eles fazem o que vendem de peixe na balsa...

JC: Só lá pra cima...?

Francisca: Aquele pessoal de perto dali da igreja...

JC: E eles vendem pra lá?

Francisca: (...) alimento do dia (...)

JC: A senhora gosta de morar aqui? 
Francisca: Desde de quando nasci. Nasci, me criei e me formei aqui mesmo.

JC: Mas a senhora gosta? Melhor do que na cidade?

Francisca: Muito. Você vive melhor que na cidade. Cidade não tem as coisas. Até para os alunos que estudam. Por que aqui eles encontram uma cobra. Na cidade - se for na noite - eles colocam o filho do interior pra cidade. Se não pegar a vaga do menino de rua, tudo bem. Quando dá, já estão no mesmo ritmo dos malandros de rua. Aqui eles estão estudando tranquilamente, sai, sabe que chega pra casa não tem problema nenhum. Mas na cidade é mais diferente. Aqui não, minha filha ela já tá terminando o $2^{\circ}$ dela, já vai pro $3^{\circ}$. O outro tá fazendo o $1^{\circ}$. Este aqui já tá na oitava... Se mexe, né?

JC: Eles vão pescar no lago?

Francisca: Vão. Mas só quando não tem aula pra eles que eles vão pro lago.

JC: Como é que eles seguiam pra ficar no lago?

Francisca: Vai pelo caminho do mato grosso mesmo, pega por cima. Quando é tempo de cheia, pesca aqui por perto mesmo.

JC: Caniço?

Francisca: Caniço, malhadeira, espinhel... Mas quando está tempo de verão, tem que ir por cima pra ir pegar o lago...

JC: é mais difícil?

Francisca: Mais difícil. Mais cansaço.

JC: Quer dizer que aqui é melhor do que viver na cidade? Mais tranquilidade?

Francisca: Mil vezes. Mais tranquilo.

JC: A água é na beira do rio? Toma banho no lago? Não tem arraia?

Francisca: Tem mas (...) (bocejo)

JC: E os remédios caseiros, o que a senhora usa aqui?

Francisca: Remédio caseiro é jambô. É aqueles negócios que dá em planta é remédio assim que (...)

JC: Jambô serve pra quê?

Francisca: Serve pra inflamação, serve pra ferida na boca, tudo serve. Mas diarreia, tudo é jobolon.

JC: Quais outros remédios que a senhora tem?

Francisca: Tem a mocrecida...

JC: Mocrecida pra quê?

Francisca: Também pra ferida, inflamação. É bom... (...)

JC: O que mais?

Francisca: Tem a cidreira, capim cheiroso. Tema a (cracá) que é bom pra banho...

JC: E frutas você planta aqui?

Francisca: Frutas... só estes ingazeiros que escapou da água.

JC: a água, quando vem, leva tudo?

Francisca: Leva tudo. É bananeira é tudinho leva. 
JC: Quer dizer que, a cada vazante é um recomeço?

Francisca: Cada vazante... tem planta que tiver... que vim a água, leva tudo, tudo mesmo.

JC: depois tem que plantar tudo de novo?

Francisca: tem sim. Negócio de bananeira aqui, quando a água vem, leva tudo, morre tudo.

JC: (...) tem cheiro-verde?

Francisca: a minha filha é que tem lá em cima (...)

JC: E ela não vende lá no barco?

Francisca: Ela troca o cheiro (...) lá na balsa...

JC: Que bom, né? Quer dizer que a senhora não troca o interior pela cidade?

Francisca: Não. Eu só apareço mesmo quando vou levando o menino no hospital e quando eu vou receber dinheiro do bolsa-escola deles.

JC: Não quer comer peixe congelado? Quer fresquinho?

Francisca: Fresquinho.

JC: Que bom, né? E seus filhos, querem ficar aqui também ou vão pra cidade?

Francisca: Aqui mesmo. Melhor aqui do que na cidade.

JC: A senhora estudou até que série?

Francisca: Estudei até a metade da $4^{\mathrm{a}}$ série - que eu esperava o tempo - a gente tinha que trabalhar, eu parei.

JC: a professora era a Vânia?

Francisca: Foi, com ela mesmo.

JC: a Vânia formou muita gente aqui?

Francisca: Foi, foi no tempo que eu procurei filho e eu saí da escola mesmo.

JC: Não foi o boto não?

Francisca: Não (risos). Não foi o boto que me emprenhou.

JC: Não?

Francisca: A minha irmã que estudou até a $4^{\mathrm{a}}$. Ela estou tudo, a $4^{\mathrm{a}}$ dela.

JC: Com a Vânia também?

Francisca: Com a Vânia também.

JC: A Vânia trabalhou com muita gente. Melhor, era a única professora daqui?

Francisca: No nosso tempo era só ela de professora... Não tinha quem fizesse merenda. Não tinha merenda mesmo! Enchia a água do pote era os alunos. Quem abre a escola eram alunos com ela. Não tinha negócio de zelador...

JC: Falo em pote e eu lembrei: antes vocês pescavam e tinha uma forma de conservar o peixe?

Francisca: Era no gelo, salgado...

JC: Mas antes já tinha gelo? 
Francisca: Não, não tinha gelo. Era só o salgado mesmo. E quando era bodó botava no caixa com água... era assim.

JC: E agora, só no gelo?

Francisca: Agora não. Quando é peixe... só o bodó põe na água mesmo. Quando é peixe branco, salga.

JC: Agora... por quê que a lua apodrece o peixe tão rápido?

Francisca: Porque ela é mais quente do que o sol. Ela apodrece mais rápido.

JC: Se não cobrir com o capim...

Francisca: Ela faz apodrecer o peixe. O sol pega no peixe mas ele não apodrece tão rápido. Agora é mais quente do que o sol...

JC: E tem que ter cuidado quando tá pescando a noite, com a lua?

Francisca: Verdade.

JC: Tá bom então, dona Francisca.

\section{Dona Maria}

JC: Quantos filhos a senhora tem, dona Maria?

Maria: Eu tenho 12. Eu tive 14.

JC: Quantos homens e quantas mulheres?

Maria: 12 mulheres e 2 homens. Só 2 homens. Só tive dois filhos homens. O resto só mulher. Morreu duas meninas e ficou 10. Todas as 10 são vivas.

JC: Moram todos com a senhora?

Maria: Não senhor. Moro com esta aqui, com a moreninha e a Cristiane e a minha caçula. (...) estudavam aqui e a mãe deles está em Parintins, aí fica difícil lá, sabe. Ela fez tudo pra tirar daqui, sair pra Parintins, chegou lá, cadê (...) (...) (...) E lá eu tinha filho. (...)(...)(...) e lá eu tinha filho - "minha filha, eu te falei: olha, eu tenho uma casa alugada lá. Mas eu não vivo só lá" - tem até um neto que tá pra lá. (...) Aí, ela entendeu de arrumar um companheiro, um rapaz novo, ela com 33 anos e ele com 16. Logo no começo ela foi... depois não foi dando mais certo. Ela pegou e foi embora, acho que gostou mais do companheiro do que dos filhos... (...)

JC: Me conte, como é que foi que surgiu esta história de vender lá nas balsas do navio?

Maria: Como foi?

JC: É. Foi a senhora que começou tudo.

Maria: Olhe... eu vivi 22 anos com o pai dos meus filhos. A peleja não era fácil não. Hoje já piso em tábua. Aquela era ripeira da beirada. Casinha de palha. E eu confio nos meus filhos e sempre o pai continuava bebendo, bebendo, bebendo... e ficava por aí. (...) Minha ainda mãe era viva. Minha mãe dizia assim "minha filha, aguenta". Depois da segunda filha - professor - eu queria desistir. Eu queria desistir, "to vendo que não dá certo" (...) "O que eu comer, tu come". (...) Os filhos iam aparecendo, 
aparecendo, aparecendo, e já tava vendo - perdendo meu tempo - eu desisti mesmo (...). Eu peguei de chorar e disse para os meus filhos "olha, meu filho, sabe porque eu to chorando. Pra mim já é até uma vergonha, teu pai só fazer filho pra ficar pra você? Se consumir comigo, meu filho? Mas eu vou te dizer: daqui pra frente eu vou criar vergonha na minha cara. Eu não vou querer mais teu pai. Eu não quero, eu não quero mesmo". Ele disse "não, mamãe. Agora nós já somos homens" (...). eu vou ter minha filhinha, se Deus quiser. Mas como Deus achou que - antes eu ficasse lutando com os aqueles que tão grandinhos - que é como um peixe, Deus tirou. Eu sei porque Deus tirou. Por isso, porque Deus teve pena de mim. Uma criança não é fácil não. Pra viver no mundo pra sofrer. E eu tenho isso que Deus tirou por isso. Deus tirou porque bastava a tarefa prontinha. E eu não quero, não quero mesmo. E eu não quero mais ele, eu não quero mesmo. Ai, quando interou uns quinze dias, um dia ele apareceu. Ele tava com cinco meses por aí. Aí eu disse pra ele. Eu fui uma mulher, eu fui forte mesmo e sou forte - graças à Deus - de uma pessoa que eu pensei muito na minha vida, me casei. A hora que eu prometi que eu ia ser uma chefe de família - e prometo até o final da minha vida - fiquei sem marido, não tinha ninguém, cuidei dos meus filhos. (...) Aí eu fui levando a vida (...).

Foi, foi, até que um dia nós dividimos mesmo (...).

Eu to com cinquenta e poucos anos mas mesmo assim. Tenho uma faca no meio do balcão (...).

Eu tinha ficado assim... com um monte de criança. E naquele tempo ainda não recebia o bolsa-escola, professor. Naquele tempo existia. Mas pra nós, nada. Ainda não tinha. (...) Estes outros todos, professor, criei tudinho meus filhos, com o poder de Deus, (...) no tempo eu não tinha criação, tudo por aquela roça, era macaxeira, era bananal, era feijão pela beirada.... e fui criando meus filhos sem o bolsa-escola. Da Geise já que eu peguei. E aí, de lá, quando nós separamos de uma vez. (...) só que não era um salário, era uma gratificação que ele ajeitou pra ela. Ela ganhou 50 cruzeiros, no tempo do cruzeiro. Mas ela sabia tudo, hoje ela sabe tudo, ser a malhadeira, ela sabe fazer. No trabalho dos seus 50: "mano tu tece esta malhadeira pra mim", "mano tu faz isto pra mim, conserta esta malhadeira pra $\operatorname{mim} "(\ldots)$

JC: Quem ensinou ela a tecer malhadeira, a fazer malhadeira?

Maria: O irmão dela, o irmão dela é um pescador mesmo...

JC: E quem ensinou ele?

Maria: Quem ensinou ele? Foi no tempo que estes parentes vieram do Pará. Antigamente não existia quase a malhadeira por aqui. Não existia a malhadeira. Era arpão, pneu, tacape... Meu pai disse "só de arpão". Meu pai nunca foi de malhadeira. E aí, foi o tempo que estes parentes, que vieram do Pará, vinham pescar pra cá. E colocavam aqui na ponta (...) e eu to vendo uma pessoa que tá fazendo uma coisa que é bom. E a gente que tem vontade de aprender, aprende. Aí, de lá, eu já passava pras meninas. Ai, de lá - naquele tempo não tinha celular - era só o telefone daquele de dentro de casa mesmo. Aí, eles paravam aí (...). Nós fazia piracuí, pegava um bodó de tarrafa e nós ia fazer o piracuí. (...) (balseiro) "vocês não tem verdura?" (Geise) “o que mais nós temos é verdura” (balseiro) "olha, 
quando passar aqui, eu vou parar". (...) Ainda tem umas que param. Mas agora não. Mas também não vão com muita velocidade. Aí, aquelas iam parando aqui no porto. Queriam o feijãozinho da praia, era o peixinho, uma verdura. Assim foi o começo da nossa venda aqui. Foi assim. Agora não, agora eles já tão conhecido mesmo aqui. Eles já param. Tem gente conhecido mesmo. Tem gente até daqui de Parintins mesmo, parente das meninas, quando não, é daqui mesmo. E assim foi o começo, professor. Um dia vende um peixinho, verdura a gente toca do nosso rancho, uma galinha, uma carne...

JC: Aí, vão lá no meio do rio?

Maria: Não, ele passa aqui na beira mesmo...

JC: Pega a rabeta e vai até lá?

Maria: É, o senhor viu aquele dia?

JC: Vi! Fotografei a Cristiane...

Maria: A gente leva pra cidade também. Peixe vivo a gente leva lá pra (...)

JC: E no tempo da cheia, como é que é aqui?

Maria: A mesma coisa (...). Nossa pescaria é maior este tempo (...).

JC: você planta jerimum, melancia também?

Maria: a gente planta também. Agora a gente tá aqui porque (...) aqui é só criação. A gente faz uma planta aqui, tem que cercar mesmo. Só que nós vamos fazer um trabalho aqui em cima, aqui no terreno do meu primo, aqui em cima. Esta semana (...) vai plantar milho (...) plantar jerimum e milho - se Deus quiser - mas a gente vai fazer trabalho, faz tudo com cerca porque o gado, né. Tem muito gado do vizinho também, pode passar, e a gente vai ficar no prejuízo. E assim não (...).

JC: Aqui até as crianças sabe pilotar o rabeta?

Maria: A gente sabe.

JC: Quem ensinou?

Maria: (...)

JC: A Cristiane?

Maria: Tudo é ela que ensina.

JC: Ela faz tarrafa, eles fazem tarrafa também?

Maria: Eles tecem tudo. Ela sabe tecer tudo, talhadeira...

JC: e os mais velhos ensinando as crianças?

Maria: Os mais velhos ensinando as crianças. "Olha minha filha, bota um banquinho, bota estes menor aqui no teu lado para aprender, aprender a vida". Quem não estuda de manhã, quem estuda só de tarde, manhã ele tem que ajudar, ajudar fazer isto, fazer aquilo. Tudo é assim. A gente tem que ensinar os seus filhos porque bota os seus filhos pra aprender alguma coisa, como eles vão saber? Tem professor lá mas os professores somos nós que somos pais. Não é verdade? O senhor é professor, né? Hoje eu boto o meu filho de um jeito: "você tem que aprender", "você tem que respeitar". Não é que nós temos que falar isto? Nós como mãe? Nós como um pai, mãe? Nós temos que dizer pro nosso 
filho: tenha respeito. Se for dizer só de dona fulana, lá ele não vai obedecer só ela, a professora lá. Nós que "puxamos" aqui pra passar pra lá. Pois é. Eu já criei estes dois rapazes (...) Ele já ia embora, pro pai dele no Pará mas o pai bebia muito, eu disse: “meu filho, lá não vai ter nada pra ti não. Aqui você vai ter tempo de estudar pra ser alguém na sua vida. Mas lá não. Lá tu não vai ter tempo sabe por que? Teu pai é viciado na bebida. E ele não vai te dar o seu estudo. Com certeza. E já tá rapazinho. Sabe o que vai acontecer lá? Tu vai beber junto com ele. E tu vai parar de estudar. Fica aqui, fica do meu lado". Aí, ele veio embora comigo pra cá. Hoje ele estudou, se formou. Ele estuda em Parintins. Ele fez a oitava aqui, termino a oitava aqui e foi embora estudar em Parintins. Lá ele arrumou um trabalhinho na Brito que manteve ele lá. Ele trabalha na Brito de manhã e de tarde. E estuda à noite, estuda lá no "estadual" incentivado por aqui.

Professor, eu sei lá, meu Deus do céu. Meu Deus poderoso, eu fico aqui pensando a vida da gente, hoje em dia tem muita gente... ele não é de conversar, incentivado pelo bem... muitas vezes é por mal $(\ldots)(\ldots)(\ldots)$.

Eu to vendo se compro um terreno lá no Imaculada Conceição. Pior é que eu falei com o padre. (...) Aqui o gado vai e come. Ai vai briga. E eu pra não tá nesta peleja, eu procuro os meios de evitar, é feio viver assim. Comunidade viver com briga, estas coisas... E outra, eu já to começando - o nosso é pouco, agora vai todo dia passar, vão cortando, matando tudo, daqui mais um dia o que a gente vai ter? Nada. Então, pra que não aconteça, a gente deve cortar isto. E aí, eu to procurando um meio de me retirar daqui por causa das minhas criação porque eu acho tão bonito ter um bichinho deste criando... Nossas vacas tão parindo, ontem pariu outra de novo. Tão ali com a irmã.

Pesq: Este terreno vai até aqui no "mingau"?

Maria: Não senhor, vai embora pra trás. Só que é baixo, é "mingau"... logo aqui, tá vendo esta "mingueira", tudo é "mingau" isto aí. Tudo é cheio aqui... mas que só pra isto aqui é pequeno demais... Pesq: Tem lago aí atrás?

Maria: Tem. Mas lago assim como o Mato Grosso, não (...) Fica só no "mingau” (...) Tem uma baixa aqui mas ela seca (...) e estou pensando ver se consigo lá na Imaculada... um terreninho... comprar pra os bichos... pra levar é bom... vai embora até na beira do Mato Grosso. Mas a gente olha assim... e é uma beleza mesmo. Aí eu quero ver se eu consigo comprar um terreninho pra lá (...). Ele que tá encarregado do terreninho pra nós lá. Quero comprar pra nós botar nossos bichinhos pra lá. E ele ainda são nossos parentes. De primeiro nós morava lá, no terreno da Imaculada, lá que eu nasci, lá eu me criei um pouco, meus pais, meus avós que moravam lá.

(...) 


\section{Moradores - família (Pedro -Pai; Greiciane-filha)}

Ent: Estamos elaborando (projeto) pra ver como a gente poderia fazer

JC: Nome dela?

GOC: Greiciane Oliveria de Castro

Pesq: Aí, nós estamos elaborando um projetinho que seria comprar um trator. Comprar a associação. E a associação pode fazer as atividades com os comunitários. Pra plantar horta... plantar alguma coisa de produção... melancia. Preparar a área. A gente viria aqui noutro dia pra reunir - porque nós já estamos elaborando - o projeto praticamente já tá pronto, falta só algum documento. (...) a solução de quem vai financiar, se vai financiar ou não. A partir desta notícia, a gente vem reunir com a comunidade. Porque lá na relação ficou pra gente 56 pessoas. A gente vai ver como é que prenha, qual a área que tem... A gente tá colocando que a gente poderia trabalhar até 3ha durante um ciclo de até 10 anos, você poderia plantar naquela área fazendo rodízio. Pessoal cria boi aqui, era só pegar e trazer no próprio trator com carreta e fazer o espalhamento.

Pedro: Um ano apareceram ali embaixo (...) perto da cooperativa. Uma reunião lá pra limpar a área de juta (...) limparam tudo a área lá... foi 16ha que foi limpo lá. Cada qual tinha uma área.

Ent: A gente tá pensando assim: cada qual fazer no seu "penho". Pega um pedaço... e a família toma conta daquela trabalho, daquela área... Como os terrenos são todos (???) um próximo um do outro, aí faria... quem cria gado tem que cercar a área pra não passar. Aí, plantar milho, feijão, plantar jerimum, plantar melancia,

Tudo que mexe na terra.

Pedro: Pois é... (...)

Pedro: Mas esta doença, não sei o que que aconteceu que muita gente... o velho (...) lá de baixo. Até agora... (...) Já faz tempo. Desde 2000, 2012...

Ent: Meu irmão morreu de derrame também. De derrame cerebral. Morreu quase na hora. (...)

Camilo: Vocês moram aqui desde quando?

Ent: Tem uns 37 anos morando aqui.

Camilo: Vocês vieram de onde?

Ent: Da cidade. Boréia. Nos somos daqui mesmo.

Camilo: Daqui da Boréia. Aí ele veio, casou com a senhora e ficou aqui. Ou a senhora foi lá buscar ele? (risos)

(...)

Ent: Os pais dele moram lá (...) naquele beco.

Camilo: Aqui vocês produzem o quê? Além de criar o gado... ou não cria o gado?

Mulher: Este gado aqui é do meu filho. Nós temos uma vaca.

Pesq: Planta feijão, melancia? 
Mulher: Agora não, ninguém não tem plantado estas coisas devido este negócio de criação.

Camilo: Não planta mais nada?

Mulher: Não. Aqui neste pedaço...

Camilo: Planta juta? Qual é o seu patrão da juta?

Mulher: Antonio Ferreira. Tio Antonio.

Camilo: Vocês pescam?

Homem: Pesca agora a gente não pesca. Vai pescar aonde?

Camilo: Mas seus filhos, pescam?

Homem: Pescam.

Camilo: E a malhadeira quem faz? 